UNIVERSIDADE DE SÃO PAULO

INSTITUTO DE GEOCIÊNCIAS

\title{
PALEOTEMPERATURAS E PALEOFLUIDOS DA FORMAÇÃO IRATI NA BORDA LESTE DA BACIA DO PARANÁ: IMPLICAÇÕES PARA A GERAÇÃO E MIGRAÇÃO DE HIDROCARBONETOS
}

\section{Alexandra Fernandes Oliveira}

Orientador: Prof. Dr. André Oliveira Sawakuchi

\section{DISSERTAÇÃO DE MESTRADO}

Programa de Pós-Graduação em Geoquímica e Geotectônica

SÃO PAULO

2012 
À minha família e ao meu amor, por acreditarem em mim mais do que eu mesma. 


\section{AGRADECIMENTOS}

A Fundação de Amparo à Pesquisa do Estado de São Paulo (FAPESP) pela concessão da bolsa mestrado (processo 2009/02599-1) e pelo auxílio financeiro ao projeto (2009/52270-6) que possibilitou a realização das atividades de campo e o pagamento de análises laboratoriais.

A Coordenação de Aperfeiçoamento de Pessoal de Nível Superior (CAPES) pelos primeiros meses de bolsa de mestrado.

Ao professor André Oliveira Sawakuchi pela oportunidade de desenvolver este projeto sob sua orientação, pela dedicação, incentivo e confiança.

A doutora Rosa Maria da Silveira Bello, técnica responsável pelo Laboratório de Inclusões Fluidas do Instituto de Geociências da USP, pelos seus ensinamentos, sua colaboração em todas as etapas do estudo de inclusões fluidas, seu empenho e sua dedicação.

A Jordana Zampelli, técnica responsável pelo Laboratório de Petrografia Sedimentar do Instituto de Geociências da USP, por seu auxílio nas atividades desenvolvidas no laboratório.

Aos professores Thomas Fairchild e Jorge Hachiro pela colaboração na atividade de campo realizada no Estado do Paraná.

As minerações Calcário Vitti, Amaral Machado, Calcário Cruzeiro, Partecal Partezani e Calcário Rocha Fértil por permitirem nosso acesso às pedreiras (afloramentos) da Formação Irati no Estado de São Paulo.

Aos colegas e amigos Manuela Ferreira, Johanna Duque, Sara Nomura, Rodolfo Mineli e Cleber Calça pela ajuda nas atividades de campo realizadas.

Aos amigos e colegas de sala Emiliano Oliveira, Giselle Utida, André Zular, Milene Fornari, Ximena Villagran e Felipe Meira pela amizade e companheirismo.

A todos os alunos do Laboratório de Inclusões Fluidas do IGc-USP. 
A toda equipe da Biblioteca do Instituto de Geociências, em especial a Sandra, a Brenda e a Érica, por sua colaboração e simpatia.

Ao Instituto de Geociências da Universidade de São Paulo pela formação acadêmica recebida, infraestrutura e suporte técnico.

A todos os funcionários do Instituto de Geociência da USP que contribuíram de maneira direta ou indireta para a realização deste trabalho.

As amigas Gabriella, Thaís, Clarissa e Marcela, pela amizade e apoio. É muito bom poder contar com um time de melhores amigas como vocês.

Ao meu namorado Franklin por seu amor, carinho, dedicação e por estar ao meu lado em todos os momentos da minha vida. Seu apoio foi muito importante para a realização desse trabalho.

A minha família, em especial aos meus pais Regina e Paulo e avós Odette, Francisco e Paulo. O apoio, a confiança, o incentivo e o carinho de vocês, são fundamentais para que eu alcance meus objetivos e realize os meus sonhos. 


\section{RESUMO}

O sistema petrolífero Irati-Pirambóia tem como rocha geradora os folhelhos permianos da Formação Irati e como reservatórios principais os arenitos fluvio-eólicos permo-triássicos da Formação Pirambóia. Diversos autores associam a geração de hidrocarbonetos a partir dos folhelhos da Formação Irati ao magmatismo Serra Geral (Eocretáceo).

A análise de inclusões fluidas em minerais autigênicos tem fornecido informações valiosas para o entendimento da dinâmica e evolução de processos pós-deposicionais dentre os quais se incluem os processos de geração e migração de hidrocarbonetos.

Os estudos petrográficos realizados em inclusões fluidas aquosas e de hidrocarbonetos presentes em veios de calcita espática e quartzo, associados aos ensaios microtermométricos em inclusões fluidas aquosas, permitiram estimar as temperaturas atingidas pela Formação Irati na borda leste da Bacia do Paraná, bem como obter informações sobre características composicionais dos fluidos aprisionados.

Inclusões fluidas aquosas apresentam-se como inclusões bifásicas associadas a monofásicas, com morfologia irregular a regular e dimensões entre $5 \mu \mathrm{m}$ e $25 \mu \mathrm{m}$, nas quais a fase vapor geralmente situa-se entre 5 e $15 \%$ do volume da inclusão. As inclusões aquosas ocorrem de forma isolada no cristal (primárias), em concentrações na forma de trilhas internas ao cristal (pseudo-secundárias) ou trilhas de inclusões que seccionam os cristais (secundárias). Inclusões fluidas compostas por hidrocarbonetos possuem dimensões entre $10 \mu \mathrm{m}$ e $50 \mu \mathrm{m}$, apresentam fase vapor em proporções variáveis e com coloração escura, e cor de fluorescência à luz ultravioleta variando entre amarelada a azul pálida.

Adicionalmente, foram efetuadas análises de concentração de carbono orgânico total (COT) e enxofre. A concentração do teor de carbono orgânico total dos folhelhos da Formação Irati nos afloramentos estudados nos estados de São Paulo e do Paraná situa-se entre 0,43 e $17,41 \%$ e permitiu classificar o potencial de geração da unidade como alto a excelente. As concentrações de enxofre variaram entre 0,1 e 6,04\%, as quais sugerem controle deposicional. Em algumas localidades, é possível observar certa correlação positiva entre os teores de carbono orgânico total e enxofre. Temperaturas de homogeneização com modas entre $100^{\circ}$ e $150^{\circ} \mathrm{C}$ e que alcançam valores da ordem de $300^{\circ} \mathrm{C}$ sugerem que a Formação Irati 
atingiu temperaturas adequadas para geração de óleo leve e gás. Estas paleotemperaturas não podem ser explicadas apenas por soterramento e necessitam de fonte adicional de calor proveniente do magmatismo Serra Geral.

Observa-se a presença de dois fluidos aquosos com salinidades distintas. O fluido com salinidades variando entre aproximadamente 0 e 7,5\% em peso de $\mathrm{NaCl}$ equivalente corresponde ao fluido com salinidade mais baixa, enquanto, salinidades situadas entre aproximadamente 12 e $21,5 \%$ em peso de $\mathrm{NaCl}$ equivalente caracterizam o fluido de salinidade mais alta. Interpreta-se que o fluido de salinidade mais alta estivesse presente nos poros do folhelho gerador e que tenha migrado juntamente com os hidrocarbonetos através de microfraturas na rocha geradora. Por outro lado, o fluido de menor salinidade é possivelmente composto por água meteórica. A circulação deste fluido meteórico por fraturas subverticais seria altamente prejudicial para a preservação dos hidrocarbonetos. As inclusões de hidrocarbonetos revelaram óleo relativamente maturo e leve, condizente com as paleotemperaturas registradas e sugerindo que o óleo com alta viscosidade e baixo Grau API encontrado nos afloramentos da unidade geradora Irati e nos reservatórios arenosos da Formação Pirambóia (arenitos asfálticos) é produto de degradação.

Palavras-chave: Formação Irati, Bacia do Paraná, Inclusões fluidas, Sistema petrolífero. 


\section{ABSTRACT}

The Irati-Pirambóia petroleum system has the Permian shales of the Irati Formation as source rocks and the Permo-Triassic fluvial-eolian sandstones of the Pirambóia Formation as the main reservoirs. Several authors associate the hydrocarbons generation from shales of the Irati Formation with the Serra Geral magmatism.

The fluid inclusions analysis in authigenic minerals provides valuable information for understanding of dynamics and evolution of the post-depositional processes such as hydrocarbon generation and migration.

The petrographic investigations carried out in hydrocarbon and aqueous fluid inclusions associated to microthermometric essays performed with aqueous fluid inclusions allowed to estimate the paleotemperatures for the Irati Formation in the eastern border of the Paraná Basin as well as obtain information about compositional characteristics of the trapped fluids.

Aqueous fluid inclusions hosted in spar calcite and quartz veins are shown as biphasic inclusions associated to single phase inclusions, with irregular to regular morphology and size between $5 \mu \mathrm{m}$ and $25 \mu \mathrm{m}$. The vapor phase normally is between $5 \%$ and $15 \%$ of the inclusion volume. The aqueous inclusions occur isolated within the crystal (primary), in concentrations as trails within the crystal (pseudo-secondary) or as trails crossing crystal boundary (secondary).

The fluid inclusions composed of hydrocarbons have dimensions between $10 \mu \mathrm{m}$ and $50 \mu \mathrm{m}$, and show vapor phase in varying proportions and with dark color. The fluorescence color under ultraviolet light ranges from yellow to pale blue.

In addition, analyzes of total organic carbon (TOC) and sulfur concentrations were performed. The TOC of the Irati Formation shales outcroping in São Paulo and Paraná states varies from $0.43 \%$ to $17.41 \%$, indicating high to excellent potential of hydrocarbons generation. The sulfur rates range from $0.1 \%$ to $6.04 \%$, suggesting a depositional control as indicated by the positive correlation between the TOC and sulfur rates from some locations. The modal homogenization temperatures vary from $100^{\circ} \mathrm{C}$ to $150^{\circ} \mathrm{C}$, reaching values around $300^{\circ} \mathrm{C}$. These paleotemperatures suggest that the Irati Formation reached temperatures appropriate for light oil and gas generation. However, the paleotemperatures found cannot be 
explained only by burial and require to an additional heat source from Serra Geral magmatism.

The presence of two aqueous fluids with different salinities was observed. The fluid with salinity ranging from 0 to $7.5 \%$ weight of the $\mathrm{NaCl}$ equivalent corresponds to the lower salinity fluids, while salinities varying from $12 \%$ to $21.5 \%$ weight of $\mathrm{NaCl}$ equivalent characterize the higher salinity fluids. Thus, it was interpreted that higher salinity fluids correspond to shale pore fluids migrated with hydrocarbons through source rock microfractures. On the other hand, the lower salinity fluids are possibly composed of meteoric water, whose circulation in deeper zones through subvertical fractures would be highly damaging to the hydrocarbons preservation. The hydrocarbons inclusions showed relatively mature and light oil, suggesting that the oil with high-viscosity and low-API found in outcrops of the Irati Formation and sandstone reservoirs of the Pirambóia Formation (tar sandstones) is a degradation product.

Title: Paleotemperatures and Paleofluids of the Irati Formation in the eastern border of the Paraná Basin: implications for hydrocarbon generation and migration.

Keywords: Irati Formation, Paraná Basin, Fluid inclusions, Petroleum system. 


\section{LISTA DE FIGURAS}

Figura 1.1 Mapa com a localização das áreas de estudo. Modificado de Souza et al. (2008).

Figura 2.1 A Bacia do Paraná. Extraído de Milani et al. (2007a). 6

Figura 2.2 Coluna Estratigráfica da Bacia do Paraná. Modificado de Milani et al. 7 (2007b).

Figura 2.3 Diagrama em roseta das direções de lineamentos, obtido a partir de levantamentos aeromagnéticos na bacia. Podem ser observados dois grupos de lineamentos principais: NW-SE $\left(\mathrm{N} 45^{\circ}-65^{\circ} \mathrm{W}\right)$ e NE-SW $\left(\mathrm{N} 50^{\circ}-\right.$ $\left.70^{\circ} \mathrm{E}\right)$. Um terceiro grupo subordinado alonga-se segundo a direção E-W

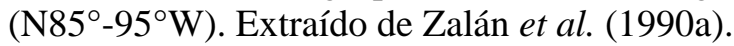

Figura 2.4 Mapa da área de ocorrência da Formação Irati em superfície nos estados de São Paulo, Paraná, Santa Catarina e Rio Grande do Sul. Modificado de Milani \& Araújo (2003).

Figura 2.5 Possível configuração paleogeográfica do mar restrito de Irati-Whitehill (Neopermiano). Extraído de Milani et al. (2007a).

Figura 2.6 Camada bioclástica presente no Membro Taquaral.

Figura 2.7 $\quad$ (A) e (B) Alternância entre camadas de folhelhos e rochas carbonáticas no Membro Assistência, Mineração Amaral Machado, localizada no município de Saltinho (SP).

Figura 2.8 Estromatólitos dômicos encontrados na frente de lavra da Mineração PH7, situada no município de Santa Rosa do Viterbo (SP).

Figura 2.9 Exemplares fósseis encontrados na Formação Irati no Estado de São Paulo. (A) e (B) Lenhos permineralizados, (C) e (D) Esqueletos de Mesosaurídeos, (E) Coquina de crustáceos e (F) Detalhe das carapaças de crustáceos. Extraído de Ricardi-Branco et al., (2008).

Figura 2.10 Afloramento da Formação Pirambóia situado na Fazenda Betumita nos arredores de Anhembi (SP). Nota-se que as fácies apresentam quantidades variáveis de impregnação de óleo.

Figura 2.11 Arenito asfáltico da Formação Pirambóia, km 174 da Rodovia Presidente Castello Branco (SP).

Figura 2.12 Migração secundária do óleo da Formação Irati (geradora) para a Formação Pirambóia (reservatório) na exsudação de Anhembi (SP). Extraído de Thomaz-Filho et al. (2008).

Figura 2.13 Quadro de eventos do Sistema Petrolífero Irati-Pirambóia. Extraído de Araújo et al. (2006).

Figura 2.14 Mapa de localização dos afloramentos estudados no Estado de São Paulo. Modificado de Perrota et al. (2005).

Figura 2.15 Mapa de localização dos afloramentos estudados no Estado do Paraná. 
Modificado de Perrota et al. (2004).

Figura 3.1 Exemplo de inclusão fluida.

Figura 3.2 Sequência de resfriamento-aquecimento de uma inclusão fluida aquosa. Etapa de resfriamento $(\mathrm{E} \rightarrow \mathrm{A}):(\mathrm{A})=$ congelamento $\left(-120^{\circ} \mathrm{C}\right)$ tendo-se gelo + vapor; (E) inclusão a $20^{\circ} \mathrm{C}$ submetida a um rápido resfriamento; (D) reaquecimento, a fusão do gelo está próxima, indicando a salinidade do fluido. Etapa de aquecimento $(\mathrm{E} \rightarrow \mathrm{I}):(\mathrm{H})$ temperatura de homogeneização na fase líquida $\left(\mathrm{Th}=54^{\circ} \mathrm{C}\right)$. Extraído de Coelho (2005).

Figura 5.1 (A) Vista geral do afloramento. (B) Camada basal com intercalação delgada de rochas carbonáticas e folhelhos. (C) Ritmito de camadas de rochas carbonáticas e folhelhos. (D) Fraturas milimétricas impregnadas por hidrocarboneto. (E) e (F) Exudação de óleo viscoso sobre calcário dolomítico. Mineração Calcário Rocha Fértil, Cesário Lange (SP).

Figura 5.2 Estereogramas referentes às famílias de fraturas milimétricas impregnadas por hidrocarbonetos e restritas às camadas de calcário na Mineração Calcário Rocha Fértil, Cesário Lange (SP). (A) e (B) Projeções planares das fraturas no hemisfério inferior.

Figura 5.3 Estereogramas referentes às famílias de fraturas na Mineração Calcário Rocha Fértil, Cesário Lange (SP). (A) e (B) Projeções planares das fraturas no hemisfério inferior.

Figura 5.4 (A) Vista panorâmica do afloramento. (B) Camada de silexito basal recoberto por camada de rocha carbonática. (C) Nível de silexito dômico. (D) Camada de folhelhos recoberta por tálus de basalto. (E) Detalhe de domo de silexito seccionado por fraturas concêntricas e radiais. Afloramento nas margens do Ribeirão Paraíso, próximo ao distrito de Paraisolândia (Charqueada, SP).

Figura 5.5 Exemplos dos veios presentes no afloramento. (A) Veio de quartzo seccionando a charneira do domo de silexito. (B) Veio de quartzo subvertical seccionando silexito. (C) Veio de calcita espática fibrosa concordante ao acamamento do folhelho. Afloramento nas margens do Ribeirão Paraíso, próximo ao distrito de Paraisolândia (Charqueada, SP).

Figura 5.6 Estereogramas referentes às famílias de fraturas no afloramento situado na margem esquerda do Ribeirão Paraíso, próximo ao distrito de Paraisolândia (Charqueada, SP). (A) e (B) Projeções planares das fraturas no hemisfério inferior.

Figura 5.7 (A) Soleira de basalto. (B) Camadas de silexito, rochas carbonáticas e folhelhos recobrem a soleira. Afloramento nas margens do Ribeirão Paraíso, próximo ao distrito de Paraisolândia (Charqueada, SP).

Figura 5.8 Soleira associada ao magmatismo Serra Geral. (A) Vista geral da pedreira (inativa). (B) Soleira de basalto em contato com siltito arenoso da Formação Corumbataí. (C) Soleira de basalto de aproximadamente 80 metros de espessura. Mineração em Laranjal Paulista (SP).

Figura 5.9 Vista geral do afloramento. Mineração Partecal Partezani, Rio Claro (SP).

Figura 5.10 (A) Vista geral do afloramento. (B) Camada basal de rochas carbonáticas intercaladas com folhelhos. (C) Detalhe do ritmito de rochas carbonáticas e folhelhos. (D) Níveis de sílex preto. (E) Falha com arrasto. Mineração Amaral Machado, Saltinho (SP).

Figura 5.11 (A) Vista geral do afloramento. (B) Dique que secciona o afloramento. (C) 
Detalhe da foto anterior apresentando detalhe do dique. (D) Detalhe da foto anterior exibindo as fraturas de resfriamento. Mineração Vitti 1, Saltinho (SP).

Figura 5.12 (A) Ritmito de rocha carbonática e folhelho. (B) Detalhe do banco de rocha carbonática (basal). (C) Detalhe do ritmito com intercalções de rochas carbonáticas e folhelhos. Mineração Vitti 2, distrito de Assistência, Rio Claro (SP).

Figura 5.13 (A) Contato entre as formações Irati e Corumbataí. (B) Vista geral do afloramento da Formação. Irati, recoberto pela Formação Corumbataí. (C) Detalhe do ritmito de rochas carbonáticas e folhelhos. Nota-se a grande quantidade de concreções de sílex. (D) Vista geral do afloramento da Formação Corumbataí. Mineração Calcário Cruzeiro, Limeira (SP).

Figura 5.14 Vista de Geral de afloramento da Formação Serra Alta situado na Rodovia Presidente Castello Branco (SP). Nota-se presença de dique clástico.

Figura 5.15 (A) Vista geral do afloramento. A seta indica a localização no afloramento do banco de rocha carbonática intercalado com níveis de folhelhos. (B) Pacote de folhelhos. (C) Detalhe da intercalação de rochas carbonáticas e folhelhos. (D) Pacote de folhelhos recoberto com ritmito de rochas carbonáticas e folhelhos. Afloramento na BR-476 próximo a São Mateus do Sul (PR).

Figura 5.16 (A) Mudstone com veio discordante de calcita espática e presença de betume. As faces da calcita sugerem contato fluido com o betume. (B) Veios de calcita microesparítica bordejando calcita espática; eventualmente pode tratar-se de duas gerações de calcita. (C) Mudstone formado pela alternância entre níveis de micrito e microesparito, similar à textura fenestral. (D) Cristais de calcita com geminação, extinção ondulante e contatos suturados. (E) Geodo de quartzo e calcita deformados e (F) Detalhe do geodo de quartzo e calcita deformados.

Figura 5.17 (A) Mudstone microespático homogêneo, sem laminação, com presença de veio de calcita espática. (B) Mudstone micrítico com laminação irregular contendo matéria orgânica e porosidade fenestral preenchida por microesparito. (C) Packstone com pelóides e bioclastos. (D) Mudstone.

Figura 5.18 Gráfico de teor de carbono orgânico total (COT) e enxofre (S) de amostras coletadas nas formações Irati, Serra Alta e Corumbataí.

Figura 5.19 Gráfico de correlação entre teor de carbono orgânico total (COT) e enxofre (S) de folhelhos da Formações Irati para amostras coletadas nos pontos 8 e 9 .

Figura 5.20 Distribuição estratigráfica das amostras coletadas no ponto 8 e seus resultados de carbono orgânico total (COT).

Figura 5.21 Distribuição estratigráfica das amostras coletadas no ponto 9 e seus resultados de carbono orgânico total (COT). O quadro acima contém os resultados de COT de amostras coletadas sem controle estratigráfico.

Figura 5.22 Fotomicrografias de inclusões fluidas pertencentes ao Grupo I. (A) Trilha de inclusões pseudo-secundárias; (B) e (D) Inclusões fluidas compostas por hidrocarbonetos observadas em microscópio petrográfico com luz transmitida, e com luz ultravioleta (C) e (E). Nota-se que as inclusões exibem fluorescência em tons amarelados e azuis pálidos.

Figura 5.23 Fotomicrografias de inclusões fluidas pertencentes ao Grupo II. (A) Grupos de trilhas de inclusões fluidas secundárias que seccionam os 
cristais de calcita espática. (B) Detalhe da fotomicrografia anterior.

Figura 5.24 Fotomicrografias de inclusões fluidas pertencentes ao Grupo II. (A) Trilha de inclusões fluidas bifásicas e monofásicas secundárias (campo C4). (B) Trilha de inclusões fluidas bifásicas e monofásicas secundárias (campo C6).

Figura 5.25 Fotomicrografias de inclusões fluidas pertencentes ao Grupo II. (A) e (C) Inclusões fluidas compostas por hidrocarbonetos observadas em microscópio petrográfico com luz transmitida, e com luz ultravioleta (C) e (E). Nota-se que as inclusões exibem fluorescência em tom azul pálido.

Figura 5.26 Trilha de inclusões fluidas pseudo-secundárias pertencentes ao Grupo III. As fotos correspondem ao campo L2-C1, que foi fotografado com auxílio de diferentes objetivas, permitindo a desde a visualização da sua posição em relação ao cristal hospedeiro (A), até a observação das inclusões bifásicas (C).

Figura 5.27 Fotomicrografias de inclusões fluidas pertencentes ao Grupo III. (A) e (B) Trilhas de inclusões fluidas pseudo-secundárias bifásicas associadas a monofásicas; (C) Inclusão fluida bifásica; (D) Possível feição de estrangulamento (necking down); (E) Inclusão fluida exibindo feição de escape de fluidos.

Figura 5.28 Fotomicrografias de inclusões fluidas pertencentes ao Grupo III. (A), (C) e (E) Inclusões fluidas compostas por hidrocarbonetos observadas em microscópio petrográfico com luz transmitida, e com luz ultravioleta (B), (D) e (F). Nota-se que as inclusões exibem fluorescência em tons azuis pálidos a esbranquiçados.

Figura 5.29 Fotomicrografias de inclusões fluidas pertencentes ao Grupo III. (A), (C) e (E) Inclusões fluidas compostas por hidrocarbonetos observadas em microscópio petrográfico com luz transmitida, e com luz ultravioleta (B), (D) e (F). Nota-se que as inclusões exibem fluorescência em tons azuis pálidos a esbranquiçados.

Figura 5.30 Histogramas de frequência das temperaturas de mudanças de fases em inclusões fluidas pertencentes ao Grupo I (hospedadas em veios de calcita espática da região de Cesário Lange). (A) Temperaturas de homogeneização total. (B) Temperaturas de fusão do gelo. (C) Temperaturas eutéticas.

Figura 5.31 Histogramas de frequência das temperaturas de mudanças de fases em inclusões fluidas pertencentes ao Grupo II (hospedadas em veio de calcita espática da região de Paraisolândia). (A) Temperaturas de homogeneização total. (B) Temperaturas de fusão do gelo. (C) Temperaturas eutéticas.

Figura 5.32 Histogramas de frequência das temperaturas de mudanças de fases em inclusões fluidas pertencentes ao Grupo III (hospedadas em veio de quartzo da região de Paraisolândia). (A) Temperaturas de homogeneização total. (B) Temperaturas de fusão do gelo. (C) Temperaturas eutéticas.

Figura 6.1 Paleofluidos da Formação Irati. (A) Histograma de frequência das temperaturas eutéticas. (B) Salinidades. O Grupo I é constituído por inclusões fluidas hospedadas em veios de calcita espática na região de Cesário Lange (SP), enquanto, os grupos II e III correspondem a inclusões fluidas contidas em veio de calcita espática e veio de quartzo, 
Figura 6.2 Histograma de frequência de temperaturas de homogeneização total de inclusões fluidas hospedadas em veios de calcita espática (grupos I e II) e de quartzo (grupo III) da Formação Irati.

Figura 6.3 Diagrama pressão versus temperatura para o sistema $\mathrm{H}_{2} \mathrm{O}$. Se um fluido apriosinado no ponto A $\left(75^{\circ} \mathrm{C}\right)$ for aquecido durante o soterramento, as pressões internas da inclusão irão seguir uma isócora em direção ao ponto B e sua pressão interna aumentará consideravelmente em comparação com a pressão hidrostática circundante. Se a inclusão sofrer estiramento devido a esta sobrepressão interna, seu volume aumentará enquanto a densidade e a pressão diminuirão. Este evento é representado por uma queda para o ponto $\mathrm{C}$, e leva a inclusão para uma nova isócora de menor densidade. Com o posterior resfriamento da inclusão essa isócora encontra a curva LV (líquido-vapor) no ponto D (numa temperatura de $100^{\circ} \mathrm{C}$ ). Assim, a inclusão terá uma densidade que irá produzir a medição de temperatura de homogenização em $100^{\circ} \mathrm{C}$. Contudo, se a inclusão nunca tivesse sido reequilibrada por stretching, sua medição de temperatura de homogenização seria de $75^{\circ} \mathrm{C}$. Traduzido de Goldstein \& Reynolds (1994).

Figura 6.4 Diagrama esquemático ilustrando o comportamento de inclusões fluidas que foram submetidas a stretching e troca de fluidos, causados pelo reequilíbrio térmico. A região compreendida pelo círculo representa as condições originais dos fluidos aprisionados antes do reequilíbrio. Modificado de Goldstein \& Reynolds (1994).

Figura 6.5 Gráficos de correlação das temperaturas de homogeneização total versus temperaturas de fusão do gelo para inclusões fluidas pertencentes ao: (A) Grupo I (hospedadas em veios de calcita espática na região de Cesário Lange -SP) e (B) Grupo II (contidas em veio de calcita espática nas proximidades de Paraisolândia -SP).

Figura 6.6 Gráfico de correlação das temperaturas de homogeneização total versus temperaturas de fusão do gelo para inclusões fluidas pertencentes ao Grupo III (hospedadas em veio de quartzo na região de Paraisolândia-SP). 


\section{LISTA DE TABELAS}

Tabela 2.1 Número do afloramento, unidade geológica, localização geográfica e 20 código da amostra(s) coletada(s).

Tabela 5.1 Resultados de Carbono Orgânico Total (COT) de amostras das formações Irati, Corumbataí e Serra Alta.

Tabela 6.1 Classificação do potencial de geração de hidrocarbonetos de acordo com o teor de carbono orgânico (em porcentagem massa) (Peters \& Cassa, 1994). 


\section{SUMÁRIO}

Resumo

Abstract

Lista de Figuras

V

Lista de Tabelas

vii

ix

Sumário

1. Introdução

1.1. Meta e objetivos

2. Contexto Geológico

2.1. Geologia Regional

2.1.1. Introdução à Bacia do Paraná

2.1.2. Formação Irati

xiv

$\mathrm{XV}$

2.1.2.1. Membro Taquaral

2.1.2.2. Membro Assistência

1

3

4

4

2.2. Sistema Petrolífero Irati-Pirambóia

2.3. Localização da área de estudo

3. Fundamentação Teórica: Inclusões Fluidas 23

3.1. Considerações gerais 23

3.2- Microscopia petrográfica $\quad 25$

3.3. Microtermometria 26

4. Materiais e Métodos 28

4.1. Descrição de afloramentos e coleta de amostras 28

4.2. Petrografia de seções delgadas 28

4.3 Análises de carbono orgânico total (COT) e enxofre (S) 28

4.4. Estudo de inclusões fluidas $\quad 29$

4.4.1. Amostras utilizadas para estudo $\quad 29$

4.4.2. Microscopia petrográfica 30

$\begin{array}{ll}\text { 4.4.3. Microtermometria } & 30\end{array}$

5. Resultados 33

5.1. Descrição dos afloramentos estudados 33

5.1.1. Pedreira da Mineração Calcário Rocha Fértil (Ponto 1) 33

5.1.2. Afloramento da margem esquerda do Ribeirão Paraíso (Ponto 2) 36

5.1.3. Afloramento na margem direita do Ribeirão Paraíso (Ponto 3) 39

5.1.4. Soleira de basalto em Laranjal Paulista (Ponto 4) 39

5.1.5. Pedreira da Mineração Partecal Partezani (Ponto 5) 41

5.1.6. Pedreira da Mineração Amaral Machado (Ponto 6) 41

5.1.7. Pedreira da Mineração de Calcário Vitti 1 (Ponto 7) 42

5.1.8. Pedreira da Mineração de Calcário Vitti 2 (Ponto 8) 45

5.1.9. Pedreira da Mineração Calcário Cruzeiro (Ponto 9) 45

5.1.10. Afloramentos da Formação Serra Alta (Pontos 10 e 11) 48

5.1.11. Afloramento Irati (Ponto 12) 49

5.1.12. Afloramento Engenheiro Gutierrez (Ponto 13) 49

5.1.13. Afloramento São Mateus do Sul (Ponto 14) 49 
5.2. Petrografia das seções delgadas

5.3. Análises de Carbono Orgânico Total (COT) e enxofre (S) 54

5.4. Estudo de Inclusões Fluidas $\quad 59$

5.4.1. Microscopia Petrográfica $\quad 59$

5.4.2. Dados microtermométricos $\quad 69$

6. Discussões

6.1. Concentração de carbono orgânico e potencial de geração de 75 hidrocarbonetos

6.2. Paleofluidos e Paleotemperaturas da Formação Irati

6.3. Implicações para geração e migração de hidrocarbonetos 87

7. Conclusões

91

8. Referências bibliográficas

Anexos

98 
A Formação Pirambóia (Permo-Triássico) na região de Anhembi e Bofete (SP) apresenta diversas ocorrências de arenitos flúvio-eólicos preenchidos por óleo de baixo grau API (arenitos asfálticos). A origem deste óleo é atribuída aos folhelhos da Formação Irati (Permiano), o que permitiu a definição do sistema petrolífero Irati-Pirambóia (Milani \& Zalan, 1999).

A concentração dos arenitos asfálticos em área geográfica relativamente restrita torna a região de Anhembi e Bofete (SP) anômala quanto aos processos de migração primária e secundária dos hidrocarbonetos gerados na Formação Irati. Apesar da existência de modelos para descrever o sistema petrolífero Irati-Pirambóia, as condições termométricas de geração e as rotas de migração dos hidrocarbonetos constituem temas ainda não completamente esclarecidos.

Em ambiente sedimentares, fluidos aquosos predominam e participam ativamente dos processos diagenéticos atuantes em uma bacia sedimentar (Goldstein, 2001). A análise de inclusões fluidas em minerais autigênicos tem fornecido informações valiosas para o entendimento da dinâmica e evolução de processos pós-deposicionais e apresenta-se como método de destaque no estudo de sistemas petrolíferos, por fornecer informações diretas acerca dos fluidos diagenéticos (Goldstein \& Reynolds, 1994; Munz, 2001).

Com o intuito de estudar as condições de geração de hidrocarbonetos da Formação Irati e a avaliação de suas características pretéritas, foram empregados métodos de análise de inclusões fluidas em minerais diagenéticos, embasados por estudos petrográficos e levantamentos estratigráficos e estruturais.

Realizaram-se ensaios de aquecimento de inclusões fluidas para investigação de temperaturas de cristalização de minerais autigênicos e temperaturas atingidas em aquecimentos posteriores relacionados à evolução geológica da unidade. Ensaios de resfriamento permitiram o conhecimento de características ligadas à composição dos fluidos aprisionados. Estes ensaios foram precedidos por estudos petrográficos preliminares para reconhecimento de assembleias de inclusões fluidas aquosas e de hidrocarbonetos. O conteúdo de carbono orgânico total (COT) de uma rocha é um parâmetro que permite classificar o potencial de geração de hidrocarbonetos das rochas na região estudada e, o teor 
de enxofre, quando correlacionado com o COT, fornece informações sobre o ambiente deposicional. Essas análises foram realizadas para avaliar a qualidade da rocha geradora.

Duas áreas foram selecionadas para este estudo, uma está localizada na região centrooeste do Estado de São Paulo e, a outra, no sul do Estado do Paraná (Figura 1.1). Na primeira área, foram realizados estudos de inclusões fluidas e análises do conteúdo de carbono orgânico total e de enxofre, enquanto, na segunda, foram realizadas apenas análises do conteúdo de carbono orgânico total e de enxofre.

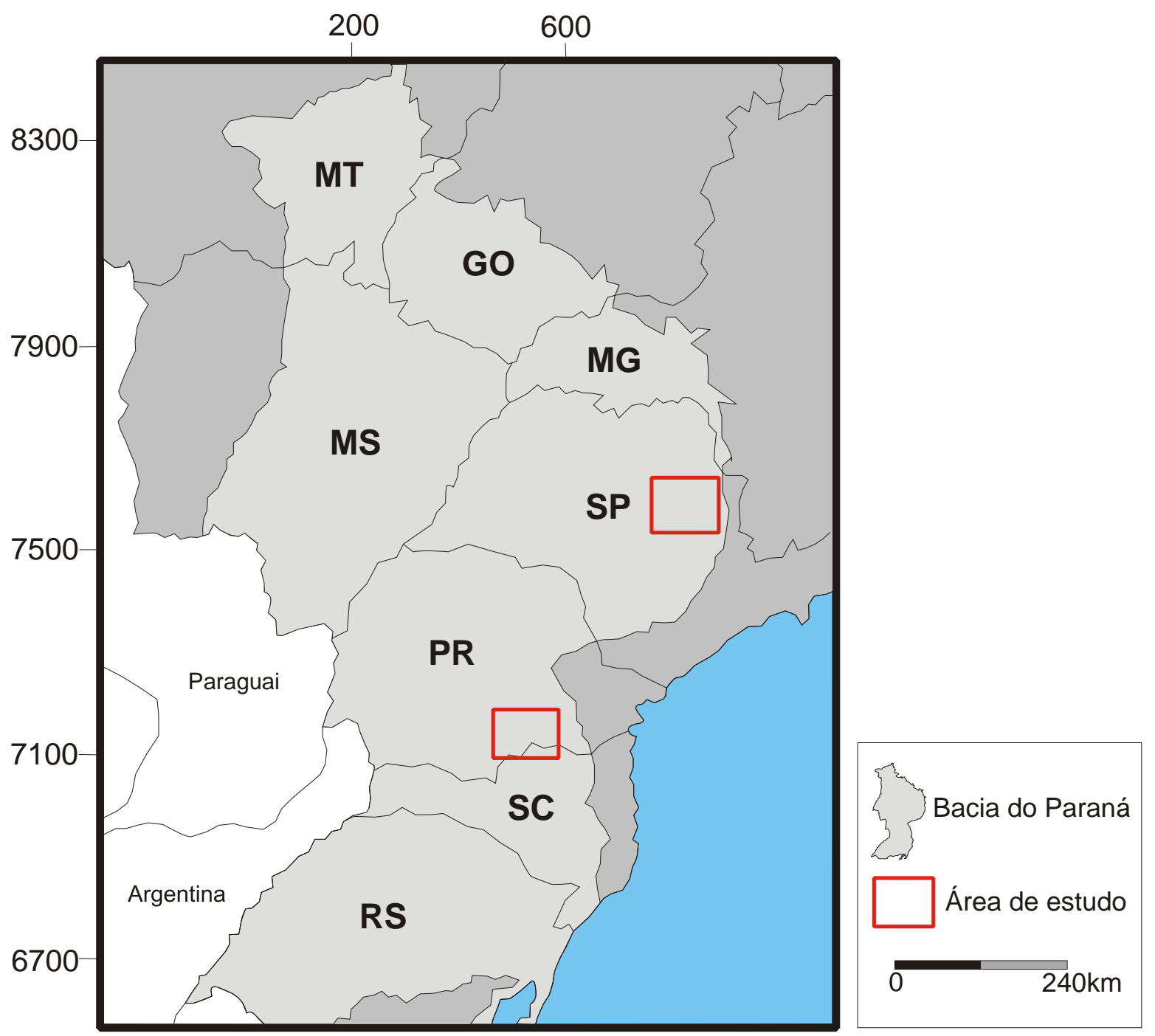

Figura 1.1: Mapa com a localização das áreas de estudo. Modificado de Souza et al. (2008). 


\subsection{Meta e objetivos}

A meta deste trabalho é a melhor compreensão dos processos de geração e migração primária dos hidrocarbonetos gerados nos folhelhos da Formação Irati. Para isto, foi enfatizada a análise de inclusões fluidas em minerais autigênicos, com a finalidade de caracterizar as condições diagenéticas de geração de hidrocarbonetos e avaliar as características pretéritas dos hidrocarbonetos. De forma a alcançar essa meta, foram estabelecidos os seguintes objetivos:

- Definição do arcabouço estratigráfico-estrutural da Formação Irati na área selecionada para o estudo microtermométrico, a partir da descrição de fácies e medidas de atitudes de elementos estruturais (fraturas e falhas);

- Descrição petrográfica das rochas carbonáticas da Formação Irati seccionadas por veios diagenéticos que hospedam as inclusões fluidas;

- Descrição petrográfica de assembleias de inclusões fluidas aquosas e de hidrocarbonetos presentes em minerais autigênicos de preenchimento de fraturas e falhas;

- Realização de ensaios microtermométricos de inclusões fluidas aquosas para reconstituição das condições termométricas de evolução da Formação Irati;

- Caracterização da concentração de carbono orgânico total e de enxofre nos folhelhos da Formação Irati e comparação com teores encontrados para amostras das formações Serra Alta e Corumbataí. 


\section{CONTEXTO GEOLÓGICO}

\subsection{Geologia Regional}

\subsubsection{Introdução à Bacia do Paraná}

A Bacia do Paraná é uma vasta província sedimentar localizada no centro-leste da América do Sul, ocupando parte dos territórios do Brasil, Argentina, Uruguai e Paraguai, totalizando uma área de aproximadamente $1.500 .000 \mathrm{~km}^{2}$. A bacia (Figura 2.1) possui uma forma oval, alongada na direção NNE-SSW (1.750km de comprimento), com uma largura média de $900 \mathrm{~km}$ e registro sedimentar que ultrapassa $7.000 \mathrm{~m}$ na sua porção central e compreende rochas com idades que variam do Neordoviciano ao Neocretáceo (Figura 2.2) (Zalán et al., 1990a). Seu contorno atual é definido por limites erosivos relacionados principalmente à história geotectônica meso-cenozóica do continente sul-americano (Milani et al., 2007a; Milani et al., 2007b). O seu nome advém do Rio Paraná, que durante 1.500km de extensão corre em sua porção central segundo o eixo de maior dimensão da bacia.

De acordo com Silva et al. (2003) o substrato da bacia compreende blocos cratônicos maciços alongados na direção NE-SW - Rio Apa, Rio Aporé, Triângulo Mineiro, Rio Paranapanema, Guaxupé, Joinville e Pelotas - separados pelas faixas móveis brasilianas Paraguai-Araguaia, Rio Paraná, Apiaí e Tijucas.

Segundo Zalán et al. (1990a), grande parte da evolução estratigráfica e estrutural da Bacia do Paraná foi condicionada por estruturas herdadas desse embasamento composto por crátons e faixas móveis que contém um grande número de zonas de fraqueza, as quais seccionam o embasamento. Tais zonas de fraqueza apresentam distribuição bimodal, como pode ser observado na Figura 2.3, que exibe um diagrama de lineamentos adquiridos através de estudos aeromagnetométricos. De acordo com Zalán et al. (1990a), lineamentos NE seriam derivados de dois cinturões móveis brasilianos, aflorantes nas margens leste e sudeste da bacia, estendendo-se sob ela através da sua porção meridional. Estes lineamentos também seriam proeminentes na porção noroeste da bacia, sugerindo a influência da faixa ParaguaiAraguaia e do lineamento Transbrasiliano. Os lineamentos NW, entretanto, possuem origem menos conhecida. Segundo os mesmo autores, existem evidências que indicam que eles sejam 
pelo menos tão antigos quanto os NE, podendo até serem mais velhos. A orientação NW-SE da faixa Uruaçu, mais antiga que o Brasiliano, seria uma dessas evidências.

De acordo com Zalán et al. (1990a) a deposição de pacotes sedimentares e vulcânicos superpostos teria ocorrido em pelo menos três diferentes ambientes tectônicos, decorrentes da dinâmica de placas relacionada à evolução do Gondwana.

Silva et al. (2003) referem-se à Bacia do Paraná como Província Paraná e a subdividem em três áreas de sedimentação independentes, individualizadas por discordâncias marcantes: a Bacia do Paraná, cuja área de sedimentação inicialmente se abria para o oceano Panthalassa situado a oeste; a Bacia Serra Geral, compreendendo arenitos eólicos da Formação Botucatu e os derrames basálticos da Formação Serra Geral; e a Bacia Bauru, uma bacia intracratônica.

No presente trabalho, contudo, é adotada a proposta de Milani (1997) na qual o arcabouço estratigráfico da Bacia do Paraná é dividido em seis supersequências (figuras 2.1 e 2.2) limitadas por expressivas discordâncias regionais: Supersequência Rio Ivaí (OrdovicianoSiluriano), Paraná (Devoniano) e Gondwana I (Carbonífero-Permiano), que correspondem a grandes ciclos transgressivos-regressivos paleozóicos de variação de nível de base, e Gondwana II (Triássico), Gondwana III (Jurárisso-Eocretáceo) e Bauru (Neocretáceo) que representam sucessões sedimentares continentais mesozóicas e rochas ígneas associadas. 


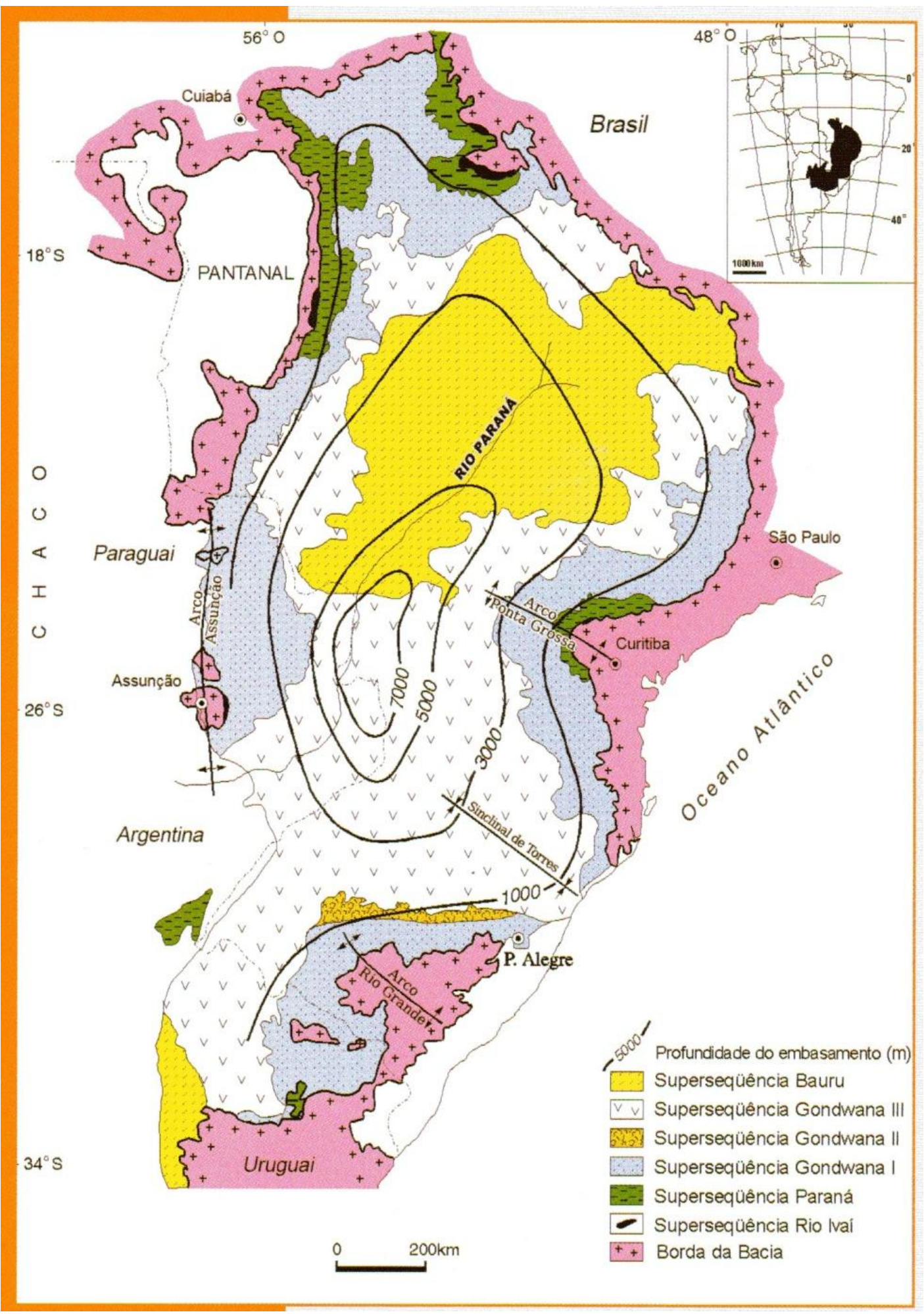

Figura 2.1: A Bacia do Paraná. Extraído de Milani et al. (2007a). 


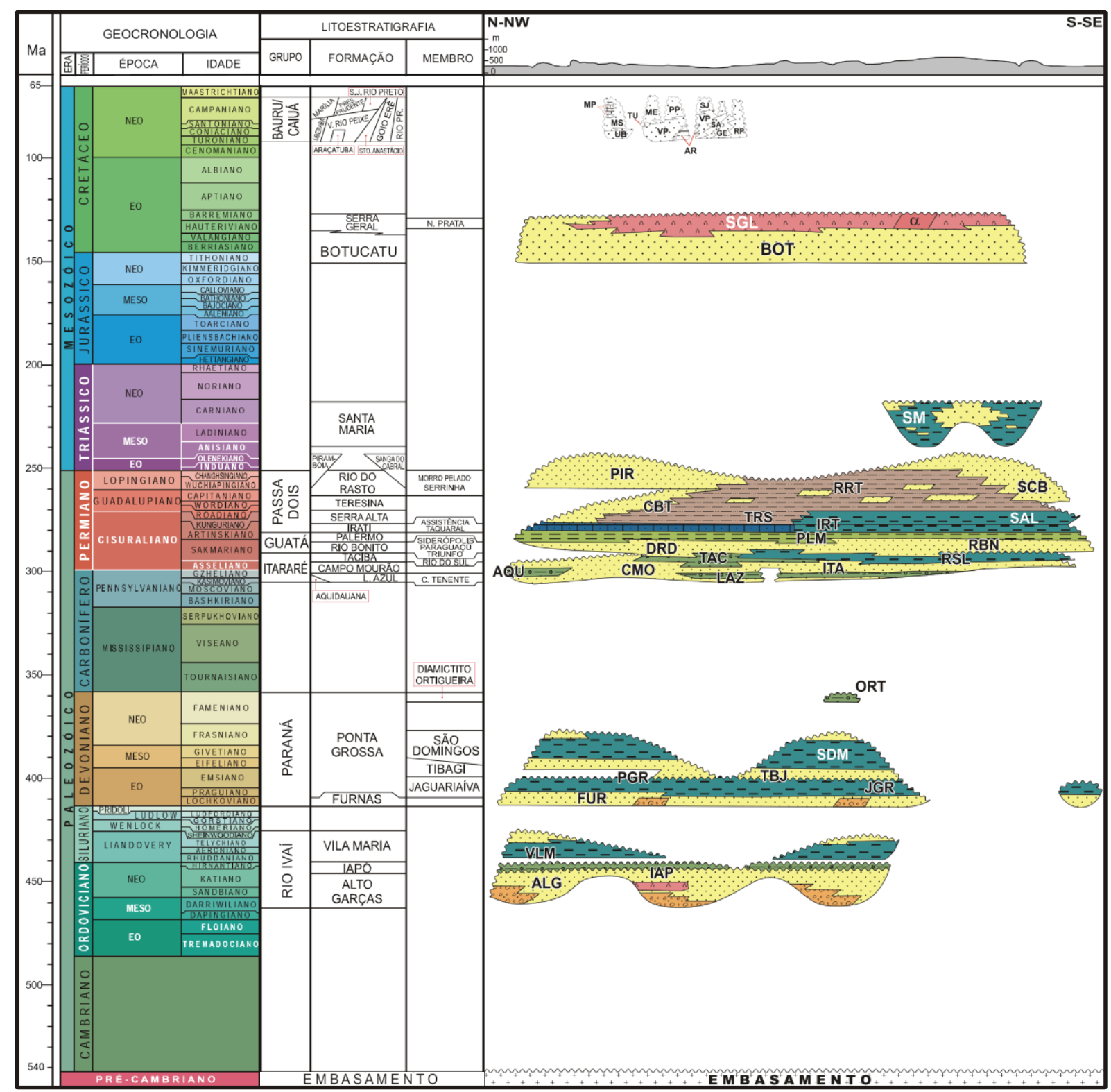

Figura 2.2: Coluna Estratigráfica da Bacia do Paraná. Modificado de Milani et al. (2007b). 


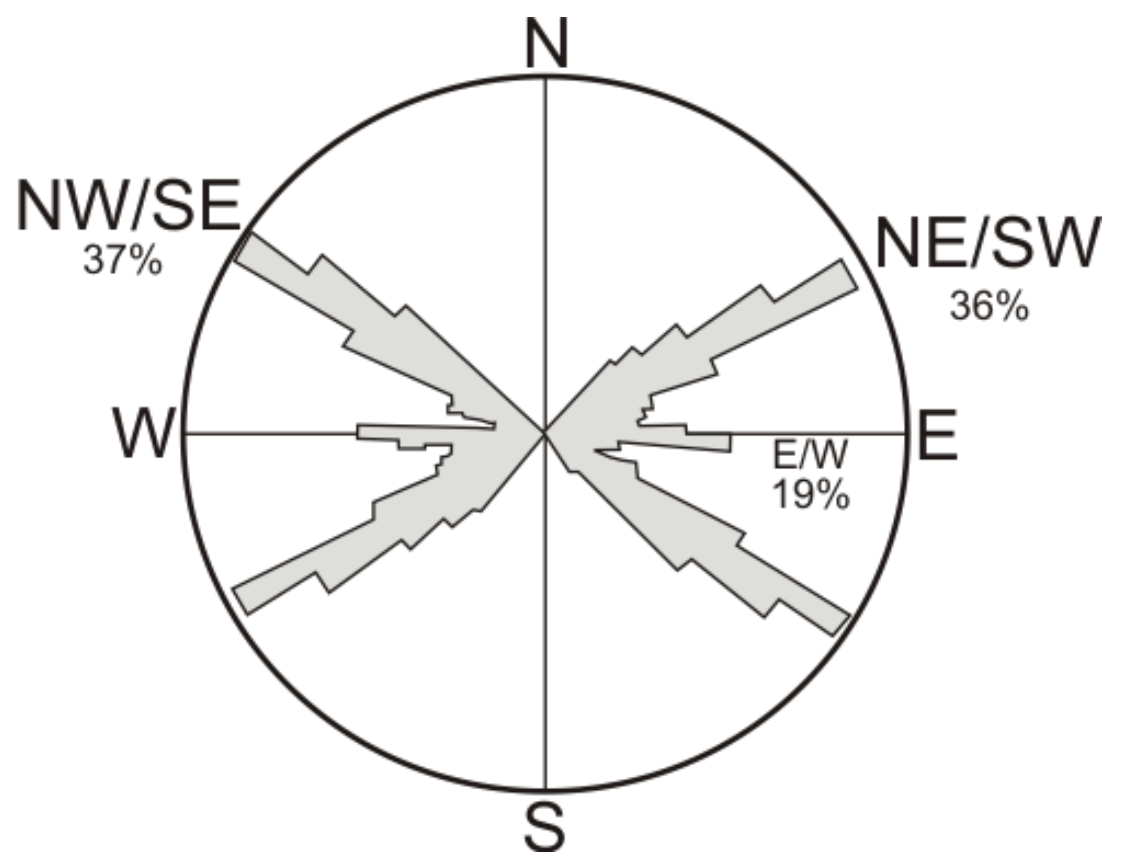

Figura 2.3: Diagrama em roseta das direções de lineamentos, obtido a partir de levantamentos aeromagnéticos na bacia. Podem ser observados dois grupos de lineamentos principais: $\mathrm{NW}-\mathrm{SE}\left(\mathrm{N} 45^{\circ}-65^{\circ} \mathrm{W}\right)$ e $\mathrm{NE}-\mathrm{SW}\left(\mathrm{N} 50^{\circ}-70^{\circ} \mathrm{E}\right)$. Um terceiro grupo subordinado

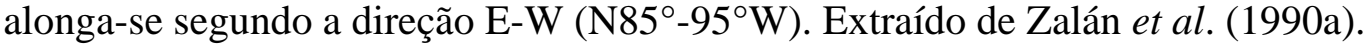

\subsubsection{Formação Irati}

White (1908) atribuiu o nome Irati para a sequência de folhelhos com restos do réptil Mesosaurus brasiliensis que aflora na cidade homônima no Estado do Paraná. A seção-tipo da Formação Irati foi definida nas redondezas da estação de Engenheiro Gutierrez em um afloramento localizado ao longo da estrada de ferro a cerca de $3 \mathrm{~km}$ da estação Irati.

A Formação Irati apresenta ocorrência generalizada na bacia e depositou-se sobre uma área de aproximadamente $1.000 .000 \mathrm{~km}^{2}$, abrangendo, no Brasil, os estados de Mato Grosso do Sul, Mato Grosso, Goiás, São Paulo, Paraná, Santa Catarina e Rio Grande do Sul, provavelmente parte do Paraguai, além do Uruguai e Argentina (Bacia do Chaco-Paraná) (Hachiro, 1996).

De acordo com Hachiro (1996), os afloramentos da Formação Irati na borda nortenordeste da bacia são encontrados entre o sudeste do Estado do Mato Grosso e sul do Estado de Goiás, enquanto que suas exposições orientais e meridionais ocorrem em uma faixa estreita, que se assemelha a um grande "S" (Figura 2.4), que a partir do município de Santa Rosa do Viterbo (SP) segue em direção ao sul do país e se estende até o Uruguai. 


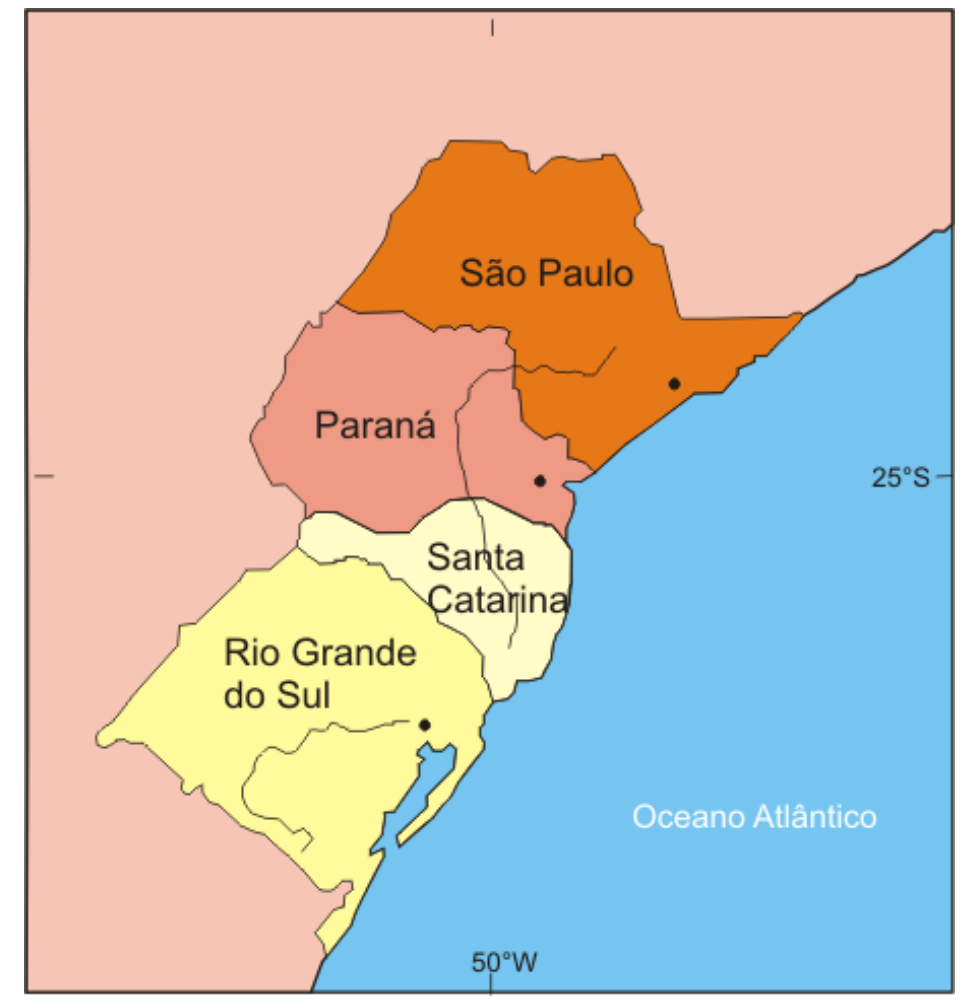

Figura 2.4: Mapa da área de ocorrência da Formação Irati em superfície nos estados de São Paulo, Paraná, Santa Catarina e Rio Grande do Sul. Modificado de Milani \& Araújo (2003).

A Formação Irati é descrita como uma sucessão de siltitos e argilitos cinza escuros a pretos, folhelhos pretos (betuminosos ou não), intercalados com rochas carbonáticas (dolomitos e calcários) e delgadas lentes de sílex nodular, sobreposta à Formação Palermo (ou Formação Tatuí no Estado de São Paulo) (Hachiro, 1991).

$\mathrm{Na}$ literatura, a Formação Irati é dividida tradicionalmente em dois membros: o Membro Taquaral, que corresponde a sequência de folhelhos e siltitos da base da unidade e o Membro Assistência, que, por sua vez, compreende folhelhos cinza escuros, folhelhos pretos betuminosos e calcários associados (Schneider et al., 1974; Milani et al., 1994; Milani et al., 2007b).

Por outro lado, Hachiro et al. (1993) propuseram a elevação dos membros Taquaral e Assistência à categoria de formação e a promoção da unidade Irati a classe de subgrupo, preservando a unidade Passa Dois na categoria de grupo. Para tais autores na Formação Assistência são definidos dois membros: a) Morro do Alto (inferior) subdividido, a partir da base, em Camadas de Folhelhos Pirobetuminosos, Camadas Evaporíticas, Ritmitos Inferiores e Camada Laje Azul; b) Ipeúna (superior) constituído, a partir da base, por Camadas Bairrinho, Ritmitos Delgados Regulares e Ritmitos Superiores. Na Formação Taquaral não foram reconhecidas possíveis subdivisões. 
A Formação Irati foi depositada em condições de mar restrito (Figura 2.5), resultando no desenvolvimento de um contexto ambiental hipersalino. Sob tais condições, acumularamse carbonatos e evaporitos na porção norte, e folhelhos betuminosos na porção sul da bacia (Milani et al., 1994; Milani et al., 2007).

De acordo com Araújo-Barberena (1993), todos os autores de estudos paleontológicos acerca da Formação Irati que a compararam bioestratigraficamente com outros sedimentos gondwânicos determinaram uma idade compreendida pelos andares Artinskiano/Tatariano (Permiano). Datações geocronológicas realizadas por Thomaz Filho et al. (1976) pelo método $\mathrm{Rb} / \mathrm{Sr}$ forneceram idade neopermiana de $256 \pm 19 \mathrm{Ma}$ correspondendo aproximadamente ao Kazaniano. Recentemente, Santos et al. (2006) atribuíram idade artinskiana (278,4 $\pm 2,2)$, por meio da datação Shrimp U-Pb em zircões presentes em camadas de bentonita encontradas dentro da unidade.

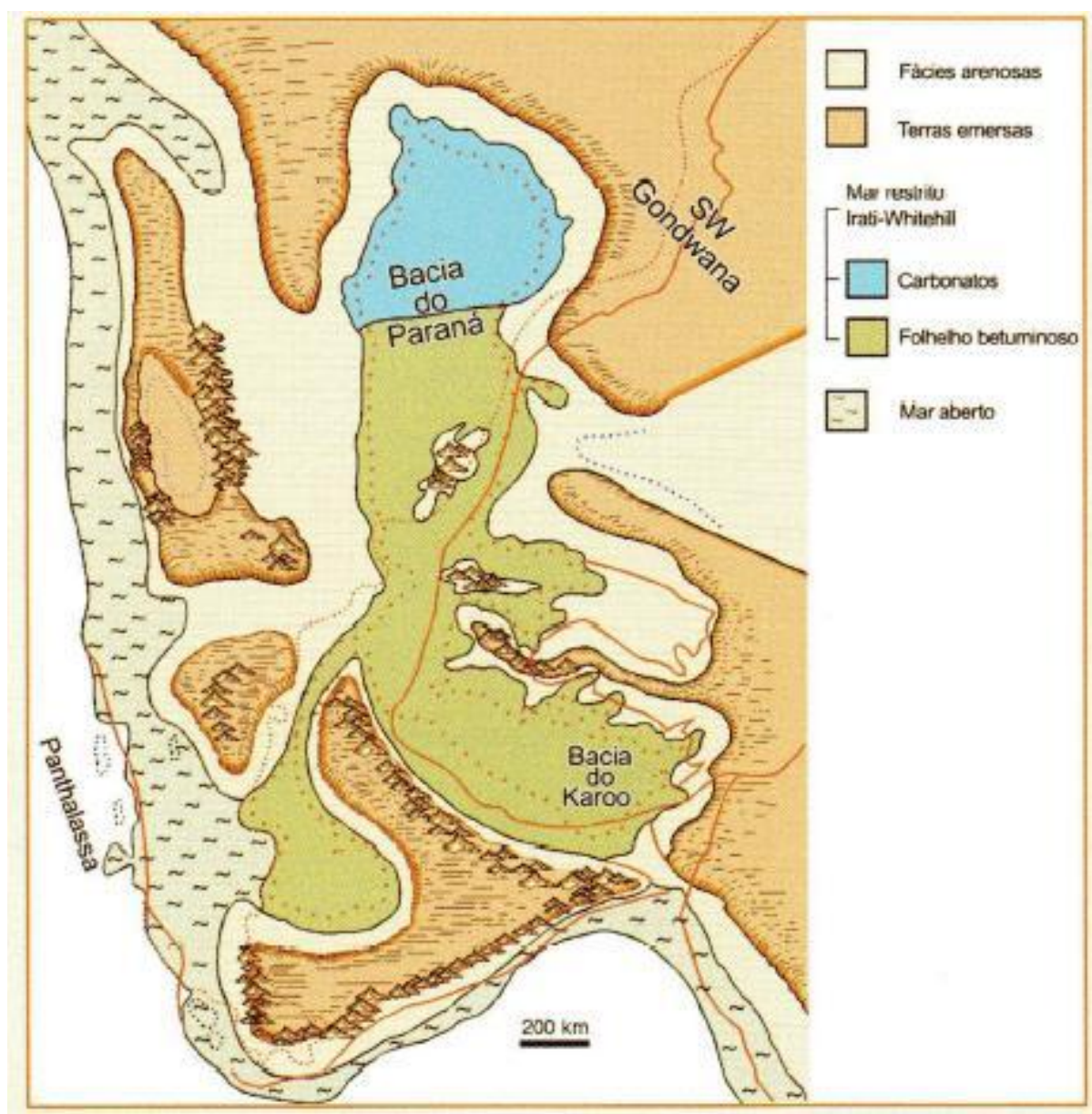

Figura 2.5: Possível configuração paleogeográfica do mar restrito de Irati-Whitehill (Neopermiano) Extraído de Milani et al. (2007a). 


\subsubsection{Membro Taquaral}

O nome Taquaral foi definido por Barbosa \& Almeida (1948) para designar os pelitos situados na base da Formação Irati. Sua seção-tipo situa-se no km 116 da estrada de ferro entre as cidades de Piracicaba e Americana (SP).

Os folhelhos siltosos cinza escuros, pouco carbonosos e não betuminosos, que compõem a maior parte desta sucessão apresentam ocorrência generalizada na bacia com espessuras variando de 5 a 10 metros nas porções marginais, podendo alcançar até $30 \mathrm{~m}$ nas porções centrais da bacia (Schneider et al., 1974; Hachiro, 1996). Hachiro \& Coimbra (1991) afirmam que esta unidade diminui de espessura na direção NNE até desaparecer.

A base da unidade é essencialmente terrígena, apresentando raríssimas e localizadas intercalações lenticulares milimétricas a centimétricas de rochas carbonáticas entre folhelhos siltosos (Hachiro \& Coimbra, 1991). A laminação paralela é a única estrutura sedimentar observada nesta unidade litoestratigráfica (Schneider et al., 1974; Hachiro, 1991).

O contato inferior com a Formação Palermo é concordante, exceto na área de São Paulo onde a presença de uma fina camada conglomerática na base da unidade, fez com que alguns autores como Barbosa \& Gomes (1958) e Barbosa \& Almeida (1948) relatassem relações discordantes. O contato superior com o Membro Assistência é concordante (Schneider et al., 1974; Hachiro, 1991).

Hachiro (1991) afirma que as áreas-fonte dos pelitos desta unidade corresponderiam às porções mais soerguidas dos arcos de Ponta Grossa, Assunção, Campo Grande e Flexura de Goiânia, situados nos arredores da bacia.

As características litológicas e sedimentares do Membro Taquaral indicam deposição em ambiente marinho de águas calmas, abaixo do nível de ação de ondas (Schneider et al., 1974).

Restos de peixes, de crustáceos do gênero Clarkecaris e da Flora de Dadoxylon são os fósseis mais frequentemente encontrados. A Figura 2.6 mostra uma fina camada bioclástica presente no Membro Taquaral. Estudos palinológicos indicam que a deposição do Membro Taquaral ocorreu no Neopermiano (Kazaniano), sendo esta idade corroborada pela recuperação de palinomorfos do Kazaniano/Tartaniano em amostras coletadas no Estado de São Paulo (Daemon \& Quadros, 1970). 


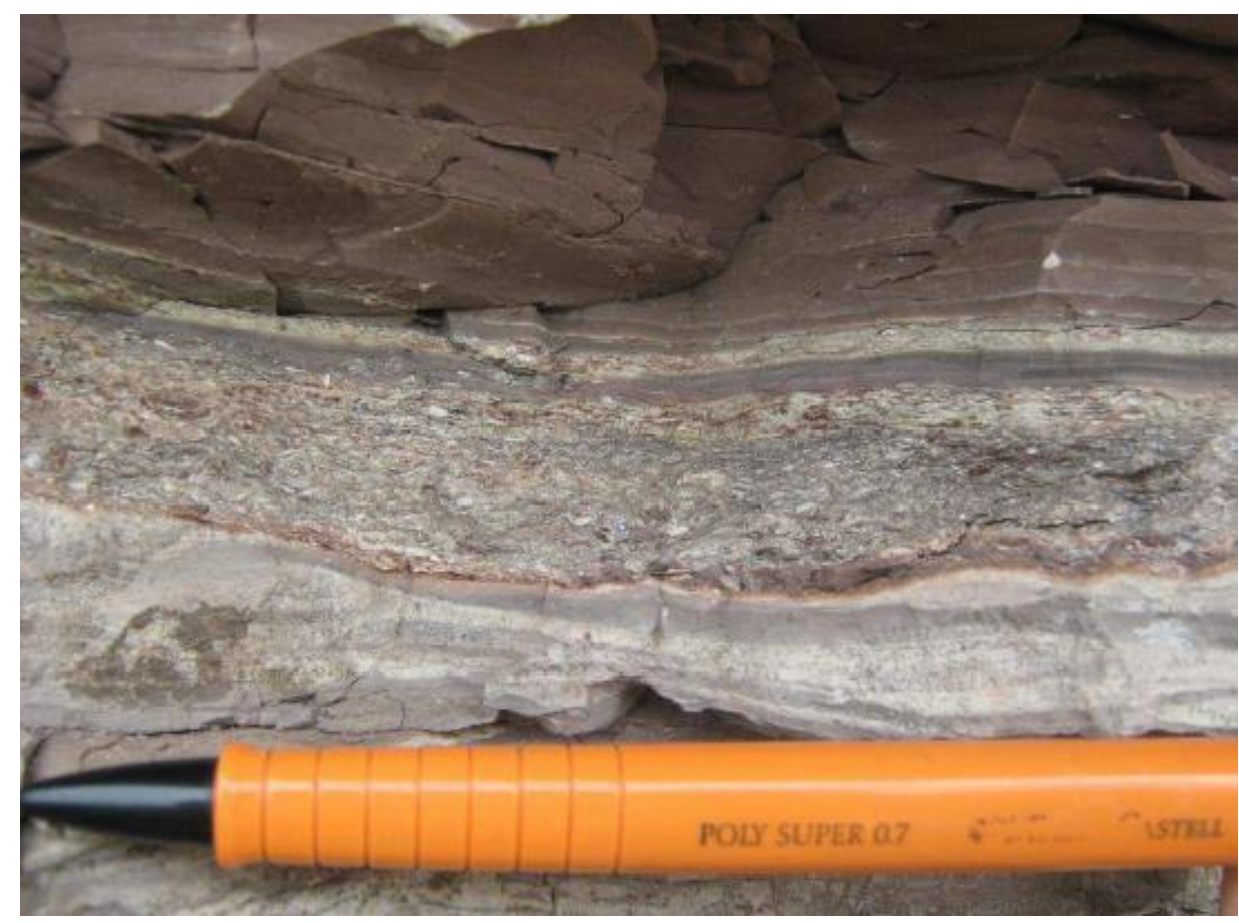

Figura 2.6: Camada bioclástica presente no Membro Taquaral.

\subsubsection{Membro Assistência}

O Membro Assistência compreende a seção de folhelhos cinza escuros, folhelhos pretos betuminosos associados a calcários, por vezes dolomíticos, situados na parte superior da Formação Irati. A designação Assistência foi atribuída por Barbosa \& Gomes (1958) que indicaram como seção-tipo as ocorrências da área de Assistência, próxima a cidade de Piracicaba, Estado de São Paulo (Schneider et al., 1974).

Hachiro (1991) descreve o Membro Assistência como constituído de folhelhos pretos, betuminosos, folhelhos e argilitos cinza escuros e rochas carbonáticas, geralmente dolomíticas. As rochas carbonáticas apresentam-se bastante silicificadas, sendo a presença de nódulos de sílex característica da unidade no Estado de São Paulo. O autor afirma que da região norte do Estado do Paraná em direção a São Paulo, há um maior desenvolvimento dos leitos carbonáticos, enquanto que as intercalações de folhelhos betuminosos tornam-se menos espessas e com menor teor de matéria orgânica.

A principal estrutura sedimentar encontrada nos leitos betuminosos é a laminação paralela. Nos leitos carbonáticos observam-se localmente marcas onduladas, laminação cruzada e convoluta, oólitos, brechas intraformacionais e laminação algálica (Schneider et al., 1974). A alternância entre camadas de folhelhos e de rochas carbonáticas é responsável pela estratificação rítmica (Figura 2.7). 
O Membro Assistência apresenta ocorrência generalizada na bacia com espessuras da ordem de 15 a 40m. O contato inferior com o Membro Taquaral é concordante. O contato superior com a Formação Serra Alta é igualmente concordante (Schneider et al., 1974).
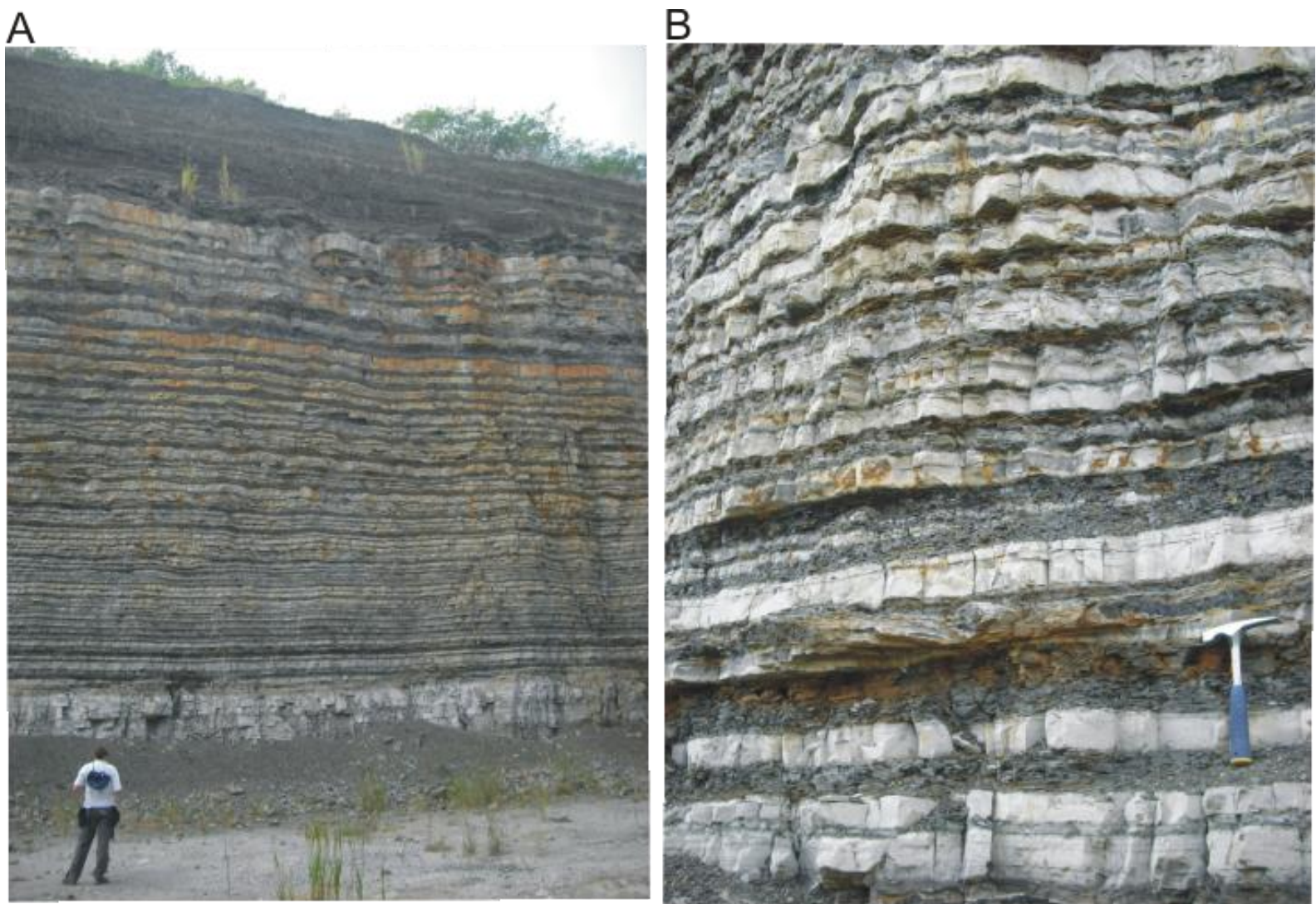

Figura 2.7: (A) e (B) Alternância entre camadas de folhelhos e rochas carbonáticas no Membro Assistência, Mineração Amaral Machado, localizada no município de Saltinho (SP).

Os sedimentos terrígenos do Membro Assistência, assim como os pertencentes ao Membro Taquaral, tiveram sua origem nas bordas relativamente mais elevadas da bacia e foram carreados para as porções mais centrais desta. Por sua vez, os sedimentos carbonáticos, possuíram como áreas-fonte colônias algálicas (estromatólitos), tais como os encontrados em Santa Rosa do Viterbo, São Paulo (Figura 2.8), situadas na borda oriental. A fragmentação, o retrabalhamento destas colônias algálicas e a remoção por correntes no sentido oeste, possibilitaram o avanço de sedimentos clásticos carbonáticos da borda oriental da bacia para o interior da mesma. A alternância entre o aporte de sedimentos sliciclásticos e carbonáticos devido às variações climáticas foi responsável pela formação de sucessões rítmicas dos pares folhelho-dolomito (Hachiro, 1996).

De acordo com Schneider et al. (1974), as características sedimentológicas do Membro Assistência sugerem deposição em ambiente marinho de águas rasas. Restrições da bacia teriam favorecido a deposição de folhelhos ricos em matéria orgânica associados a 
calcários, os quais se desenvolveram preferencialmente em áreas de plataforma, onde condições de restrição mais efetivas originaram, inclusive, sedimentos evaporíticos (anidrita).

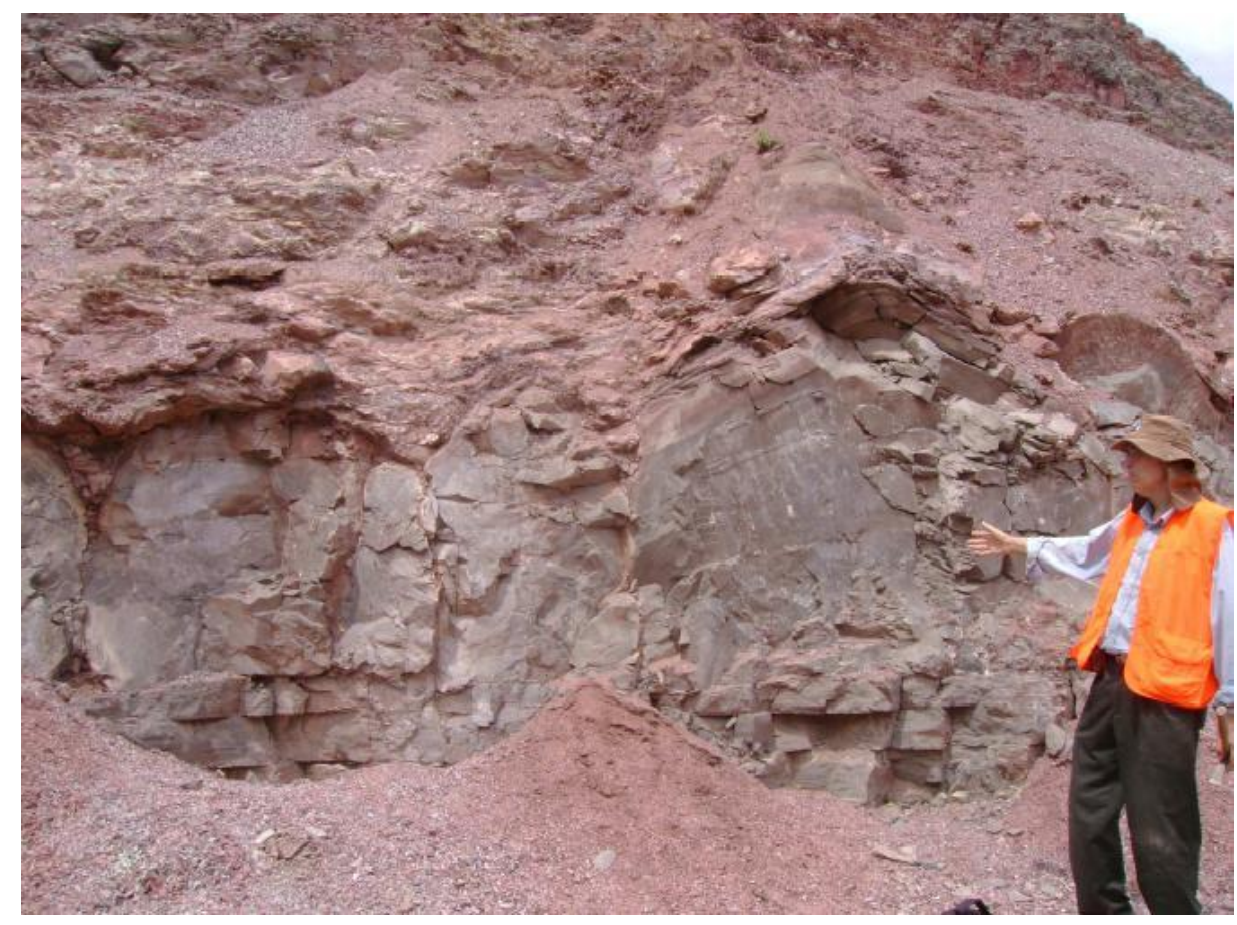

Figura 2.8: Estromatólitos dômicos encontrados na frente de lavra da Mineração PH7, situada no município de Santa Rosa do Viterbo (SP).

Os fósseis característicos da unidade são os répteis Mesosaurus brasiliensis, Stereosternum tumidum e Brasilosaurus sanpaulensis. Além desses, restos de peixes, restos vegetais, carapaças de crustáceos e palinomorfos são relativamente comuns no Membro Assistência (Schneider et al., 1974). Fairchild et al. (1985) identificaram estromatólitos nesta unidade, situados na localidade de Santa Rosa do Viterbo (Figura 2.8). A Figura 2.9 apresenta alguns exemplares fósseis encontrados na unidade Irati no Estado de São Paulo por RicardiBranco et al. (2008).

Amostras coletadas no Estado de São Paulo forneceram palinomorfos da Kazaniano/Tartaniano. Da mesma forma, Daemon \& Quadros (1970) situam a deposição dos sedimentos deste Membro no Neopermiano (Kazaniano).

A Formação Serra Alta, que apresenta contato concordante com a Formação Irati e está situada estratigraficamente acima desta, constitui-se de uma sequência de argilitos, folhelhos e siltitos cinza escuros a pretos, com fratura conchoidal, e presença de lentes e concreções calcíferas. Milani et al. (2007b) interpretam esses depósitos como relativos ao "afogamento" do "golfo Irati", correspondendo à última incursão marinha importante registrada na Bacia do Paraná. 

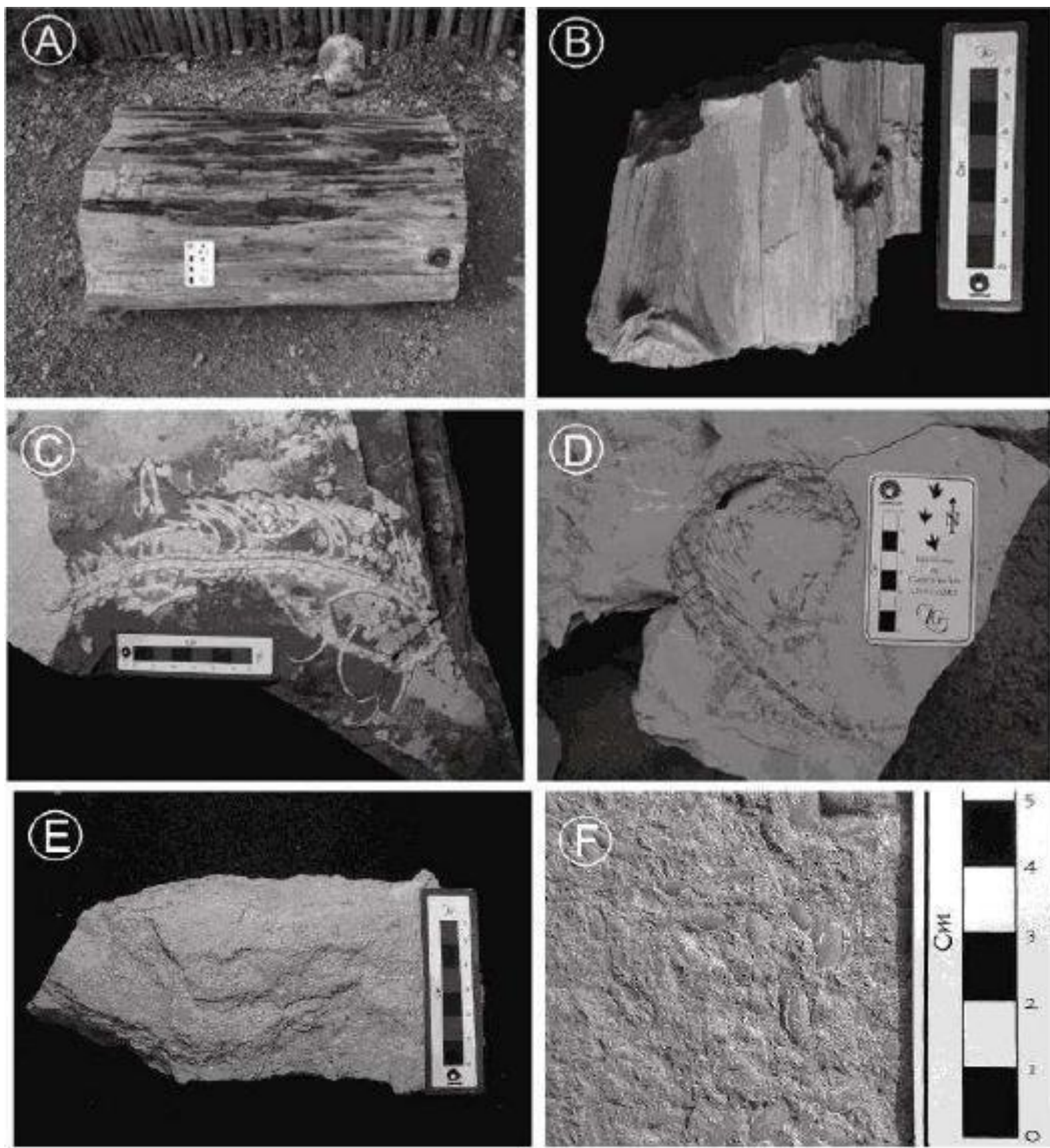

Figura 2.9: Exemplares fósseis encontrados na Formação Irati no Estado de São Paulo. (A) e (B) Lenhos permineralizados, (C) e (D) Esqueletos de Mesosaurídeos, (E) Coquina de crustáceos e (F) Detalhe das carapaças de crustáceos. Extraído de Ricardi-Branco et al., (2008). 


\subsection{Sistema Petrolífero Irati-Pirambóia}

Segundo Demaison \& Huizinga (1994) o sistema petrolífero é um sistema físicoquímico que gera e concentra petróleo. Os elementos que compõem um sistema petrolífero são as rochas geradora e reservatório, além de selante e armadilha. As rochas geradoras são rochas com teor e tipo de matéria orgânica (querogênio) adequados à geração de hidrocarbonetos. Os reservatórios são representados por rochas com propriedades permoporosas capazes de armazenar e transmitir hidrocarbonetos. Os selantes constituem barreiras de permeabilidade que restringem a migração dos hidrocarbonetos, enquanto que as armadilhas são arranjos entre reservatórios e selantes que propiciam o acúmulo de hidrocarbonetos em subsuperfície. Os hidrocarbonetos são gerados pela maturação termal do querogênio (geração), que podem ser expulsos da rocha geradora (migração primária) e passarem a migrar por caminhos de maior permeabilidade (migração secundária).

Estes elementos e processos são condicionados por características deposicionais e pósdeposicionais, cuja variabilidade tempo-espacial implica em grande diversidade de sistemas petrolíferos, o que faz com que a evolução de cada sistema petrolífero apresente características particulares. O reconhecimento dos elementos e o entendimento dos processos de um sistema petrolífero são fundamentais para a elaboração de modelos de exploração de hidrocarbonetos. Sistemas petrolíferos afetados por atividade magmática podem apresentar zonas com rocha geradora matura de distribuição espacial irregular, definida pela complexidade do fluxo térmico (Jones et al., 2007). Nestes sistemas torna-se fundamental compreender a influência do magmatismo sobre a geração e preservação de hidrocarbonetos.

O sistema petrolífero Irati-Pirambóia tem como rochas geradoras os folhelhos betuminosos da Formação Irati e como reservatórios os arenitos das formações Rio Bonito (sul) e Pirambóia (norte). Segundo Milani et al. (2007a), óleo com grau API de 22 a $33^{\circ}$ foi recuperado na Formação Rio Bonito em poços perfurados no domínio sul da bacia. Estes óleos revelaram uma correlação geoquímica positiva com os extratos orgânicos da Formação Irati. Os folhelhos betuminosos estão presentes predominantemente na porção sul da bacia e exibem um COT de até $23 \%$. A matéria orgânica é predominantemente de origem algal, com rica composição lipídica e com tendência a gerar óleo.

Diversos autores associam a geração de hidrocarbonetos a partir dos folhelhos da Formação Irati ao vulcanismo eocretáceo representado pela Formação Serra Geral e rochas associadas (Franzinelli, 1972; Araújo et al., 2000; Araújo, 2003; Souza et al., 2008; ThomazFilho et al., 2008). Souza et al. (2008) avaliaram o efeito térmico das rochas intrusivas ígneas 
na Formação Irati e segundo os mesmos a influência térmica sofrida pelas amostras da Formação Irati em contato com corpos ígneos não depende unicamente da espessura da rocha intrusiva ígnea, mas também de outros fatores como: temperatura de intrusão do corpo ígneo, profundidade em que ocorreu a intrusão e, provavelmente, a condutividade térmica da rocha encaixante.

Na borda leste da Bacia do Paraná no Estado de São Paulo, destacam-se diversas ocorrências de arenitos da Formação Pirambóia impregnados por óleo extra pesado $\left(<10^{\circ} \mathrm{API}\right)$ (figuras 2.10 e 2.11). Dados geoquímicos evidenciaram forte correlação entre este óleo pesado e óleo extraído de folhelhos da Formação Irati (Franzinelli, 1972; Cerqueira \& Santos Neto, 1990). Franzinelli (1972) propôs que a migração do óleo dos folhelhos da Formação Irati até os arenitos da Formação Pirambóia teria ocorrido ao longo de zonas de falha e seria predominantemente vertical. Segundo Araújo et al. (2000), a expulsão dos hidrocarbonetos a partir dos folhelhos da Formação Irati seria altamente influenciada por condições de sobrepressão impostas pelo recobrimento dos folhelhos por selantes diagenéticos das unidades sobrejacentes. De acordo com estes autores, os hidrocarbonetos expulsos poderiam migrar lateralmente por dezenas de quilômetros até o encontro de descontinuidades verticais de maior permeabilidade. Thomaz-Filho et al. (2008) sugerem que o óleo tenha migrado desde a rocha geradora até a rocha reservatório ao longo de contatos com diques de diabásio, que teriam atuado como barreira de migração horizontal e caminho preferencial para migração vertical. Segundo Thomaz-Filho et al. (2008), na ocorrência de Anhembi (SP), as porcentagens de impregnação de óleo nos arenitos crescem gradativamente na medida em que se distanciam dos diques e que o maior teor de óleo ocorre nos níveis mais rasos (Figura 2.12)

A existência de rochas selantes efetivas sobre determinadas porções da unidade Irati propiciaria a formação de compartimentos pressurizados nos folhelhos geradores, que favoreceria a expulsão dos hidrocarbonetos (Araújo et al., 2000). A migração secundária dos hidrocarbonetos seria altamente condicionada pela compartimentação dos folhelhos maturos por sistemas de falhas e fraturas verticais, o que favoreceria caminhos de migração verticais em detrimento dos horizontais.

As acumulações de hidrocarbonetos na Formação Pirambóia, situadas na borda leste da Bacia do Paraná no Estado de São Paulo, estão distribuídas em área geográfica restrita. Estas acumulações estão concentradas na porção inferior da Formação Pirambóia, o que sugere tratarem-se de armadilhas estratigráficas. O petróleo encontra-se armazenado em fácies 
de dunas e interdunas, sendo que em algumas localidades é nítida a maior concentração de hidrocarbonetos nas fácies de dunas e o caráter selante das fácies de interdunas pelíticas. $\mathrm{O}$ quadro de eventos do sistema petrolífero Irati-Pirambóia encontra-se na Figura 2.13. As diversas ocorrências superficiais de arenitos asfálticos da Formação Pirambóia na região de Anhembi e Bofete (SP) diferencia esta região das demais áreas de ocorrência de arenitos asfálticos. Isto sugere evolução diferenciada do sistema petrolífero Irati-Pirambóia no Estado de São Paulo.

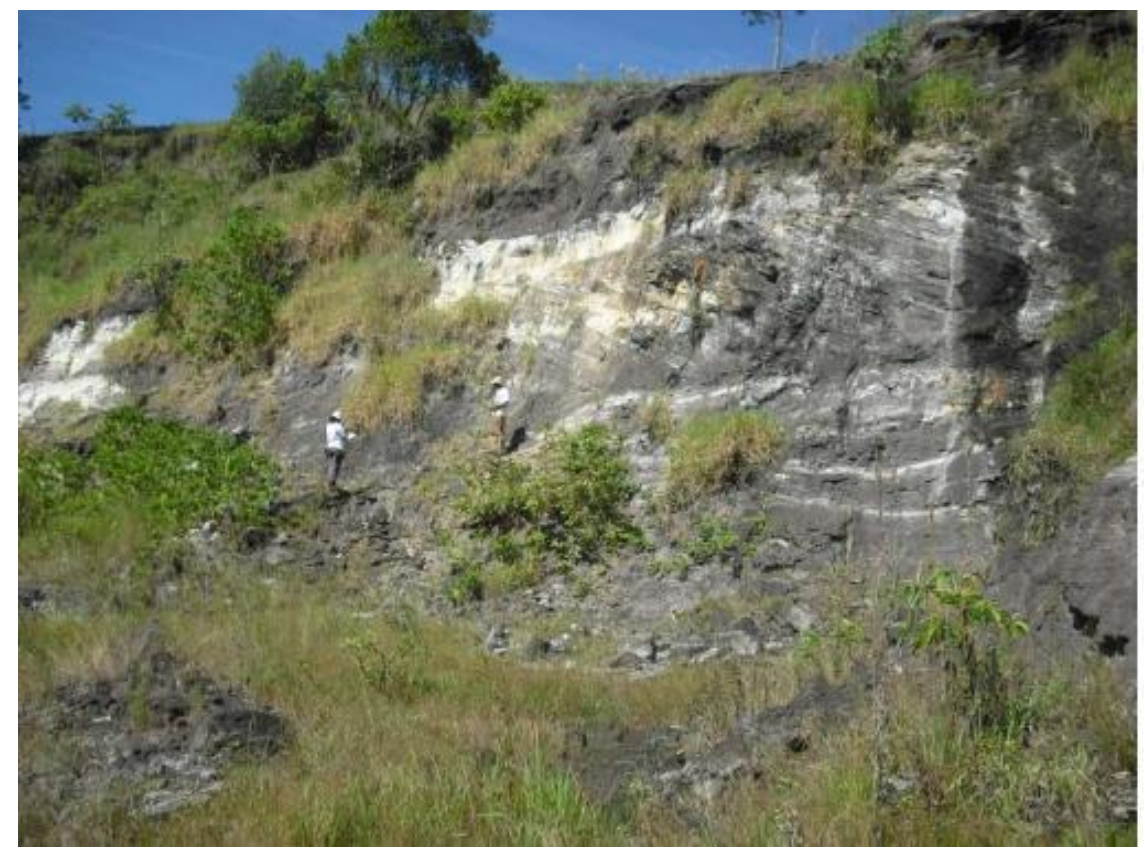

Figura 2.10: Afloramento da Formação Pirambóia situado na Fazenda Betumita nos arredores de Anhembi (SP). Nota-se que as fácies apresentam quantidades variáveis de impregnação de óleo.

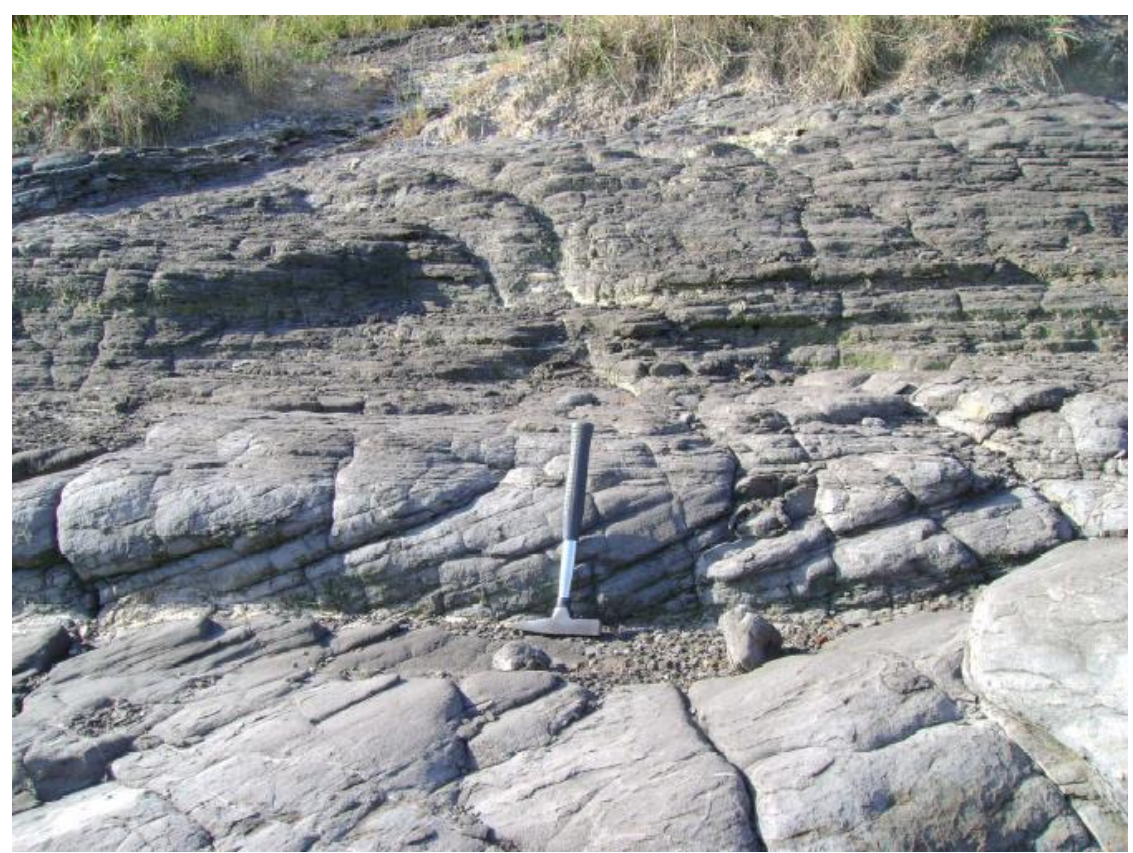

Figura 2.11: Arenito asfáltico da Formação Pirambóia, km 174 da Rodovia Presidente Castello Branco (SP). 


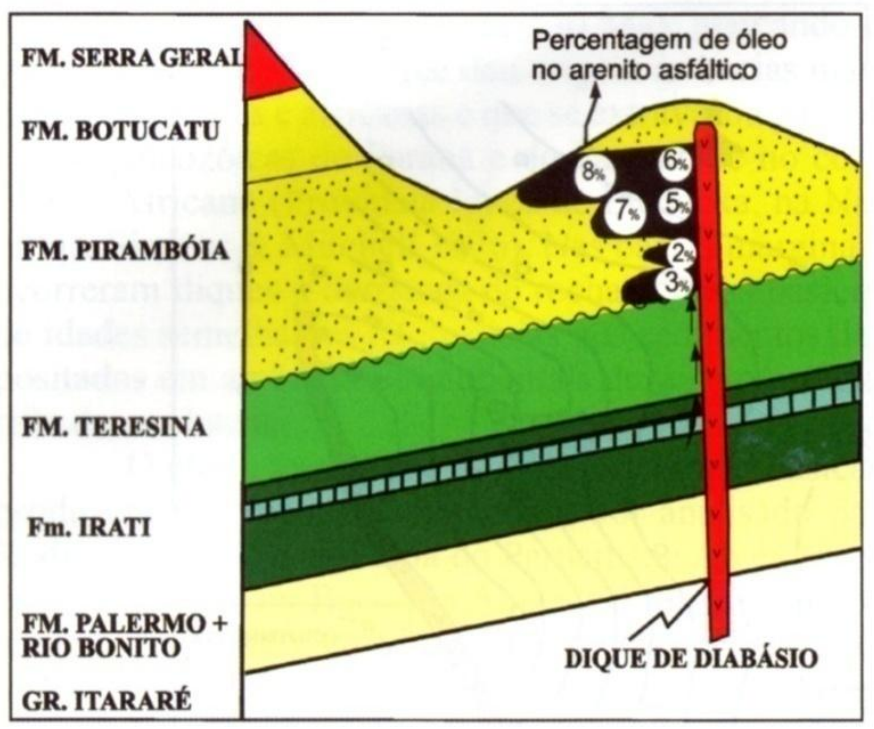

Figura 2.12: Migração secundária do óleo da Formação Irati (geradora) para a Formação Pirambóia (reservatório) na exsudação de Anhembi (SP). Extraído de Thomaz-Filho et al. (2008).

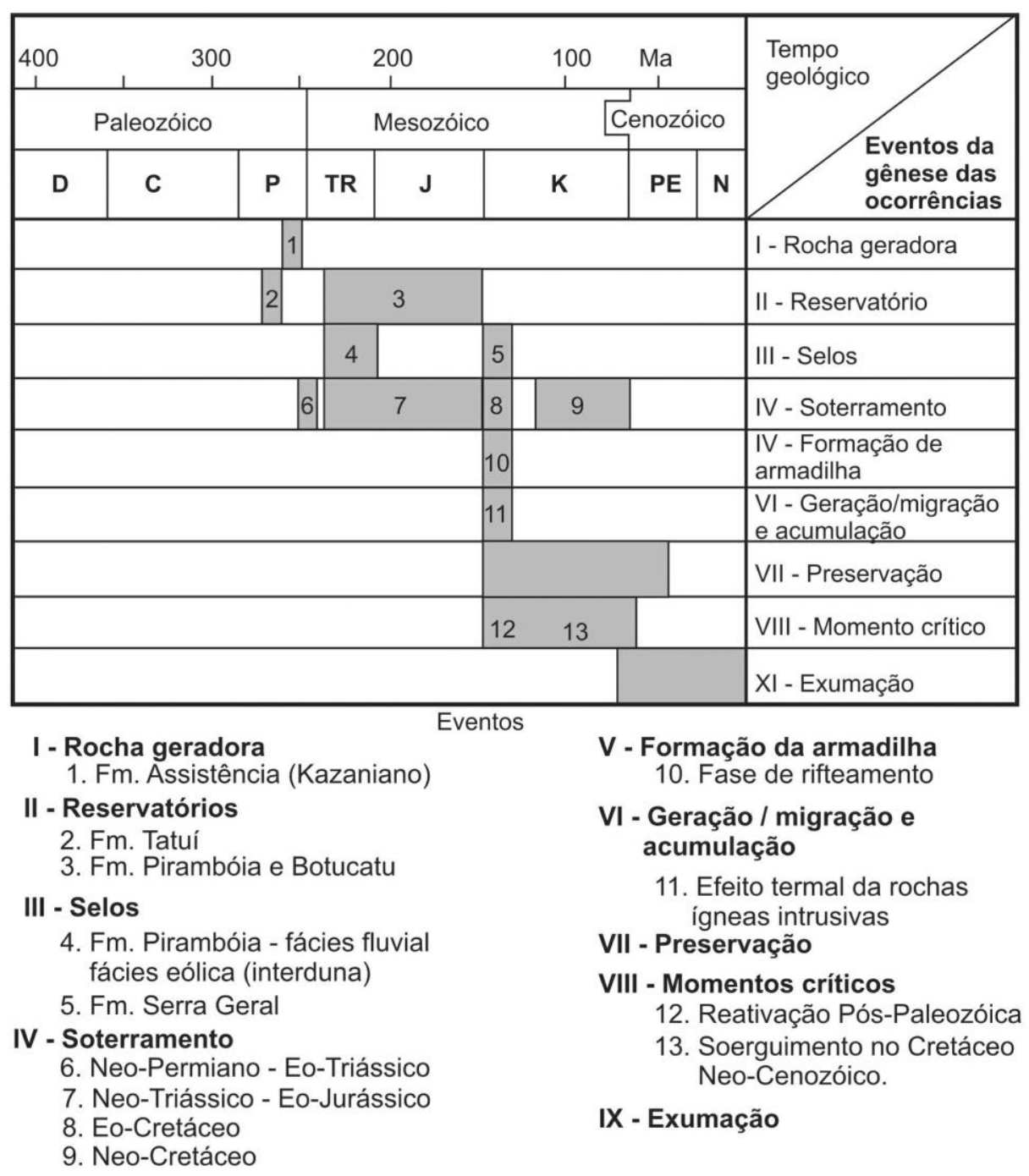

Figura 2.13: Quadro de eventos do Sistema Petrolífero Irati-Pirambóia. Extraído de Araújo et al. (2006). 


\subsection{Localização da área de estudo}

A Tabela 2.1 apresenta informações sobre os afloramentos visitados e as amostras coletadas. A Figura 2.14 corresponde ao mapa de pontos da área de estudo localizada no Estado de São Paulo, enquanto, a Figura 2.15, apresenta o mapa de pontos da área de estudo situada no Estado do Paraná.

Tabela 2.1 - Número do afloramento, unidade geológica, localização geográfica e código da $\operatorname{amostra}(\mathrm{s}) \operatorname{coletada}(\mathrm{s})$.

\begin{tabular}{|c|c|c|c|c|}
\hline Ponto & Unidade & $\begin{array}{c}\text { Latitude } \\
\left({ }^{\circ}\right)\end{array}$ & $\begin{array}{l}\text { Longitude } \\
\left({ }^{\circ}\right)\end{array}$ & $\begin{array}{l}\text { Código da } \\
\text { amostra }\end{array}$ \\
\hline 1 & Fm. Irati & $23^{\circ} 10^{\prime} 16^{\prime \prime} \mathrm{S}$ & $47^{\circ} 57^{\prime} 06^{\prime \prime} \mathrm{W}$ & $\begin{array}{l}\text { IP-08-A a } \\
\text { IP-08-I }\end{array}$ \\
\hline 2 & Fm. Irati & $22^{\circ} 31^{\prime} 44^{\prime \prime} \mathrm{S}$ & $47^{\circ} 42^{\prime} 53^{\prime \prime} \mathrm{W}$ & $\begin{array}{c}\text { MS-2B, } \\
\text { MS-2D e } \\
\text { IP-41 }\end{array}$ \\
\hline 3 & Fm. Irati & $22^{\circ} 31^{\prime} 44^{\prime \prime} \mathrm{S}$ & $47^{\circ} 42^{\prime} 59^{\prime \prime} \mathrm{W}$ & IP-40 \\
\hline 4 & Fm. Serra Geral & $23^{\circ} 03^{\prime} 18^{\prime \prime} \mathrm{S}$ & $47^{\circ} 50^{\prime} 47^{\prime \prime} \mathrm{W}$ & - \\
\hline 5 & Fm. Corumbataí & $22^{\circ} 31^{\prime} 05^{\prime \prime} \mathrm{S}$ & $47^{\circ} 34^{\prime} 17^{\prime \prime} \mathrm{W}$ & IP-29 \\
\hline 6 & Fm. Irati & $22^{\circ} 53^{\prime} 28^{\prime \prime} \mathrm{S}$ & $47^{\circ} 42^{\prime} 15^{\prime \prime} \mathrm{W}$ & IP-30 \\
\hline 7 & Fm. Irati & $22^{\circ} 53^{\prime} 15^{\prime \prime} \mathrm{S}$ & $47^{\circ} 41^{\prime} 13^{\prime \prime} \mathrm{W}$ & IP-31 \\
\hline 8 & Fm. Irati & $22^{\circ} 30^{\prime} 02^{\prime \prime} \mathrm{S}$ & $47^{\circ} 35^{\prime} 26^{\prime \prime} \mathrm{W}$ & $\begin{array}{l}\text { IP-42-F1 a } \\
\text { IP-42-F17 }\end{array}$ \\
\hline 9 & Fm. Irati & $22^{\circ} 32^{\prime} 41^{\prime \prime} \mathrm{S}$ & $47^{\circ} 26^{\prime} 26^{\prime \prime} \mathrm{W}$ & $\begin{array}{c}\text { IP-44-F5 a } \\
\text { IP-44-F10 e } \\
\text { IP-44-FA1 a } \\
\text { IP-44-FA4 }\end{array}$ \\
\hline 10 & Fm. Serra Alta & $23^{\circ} 14^{\prime} 30^{\prime \prime} \mathrm{S}$ & $48^{\circ} 06^{\prime} 07^{\prime \prime} \mathrm{W}$ & IP-01 \\
\hline 11 & Fm. Serra Alta & $23^{\circ} 14^{\prime} 30^{\prime \prime} \mathrm{S}$ & $48^{\circ} 06^{\prime} 07^{\prime \prime} \mathrm{W}$ & IP-02 \\
\hline 12 & Fm. Irati & $23^{\circ} 14^{\prime} 18^{\prime \prime} \mathrm{S}$ & $48^{\circ} 06^{\prime} 58^{\prime \prime} \mathrm{W}$ & PR-03 \\
\hline 13 & Fm. Irati & $25^{\circ} 31^{\prime} 01^{\prime \prime} \mathrm{S}$ & $50^{\circ} 39^{\prime} 27^{\prime \prime} \mathrm{W}$ & PR-04 \\
\hline 14 & Fm. Irati & $25^{\circ} 53^{\prime} 33^{\prime \prime} \mathrm{S}$ & $50^{\circ} 22^{\prime} 40^{\prime \prime} \mathrm{W}$ & $\begin{array}{c}\text { PR-05-A e } \\
\text { PR-05-B }\end{array}$ \\
\hline
\end{tabular}



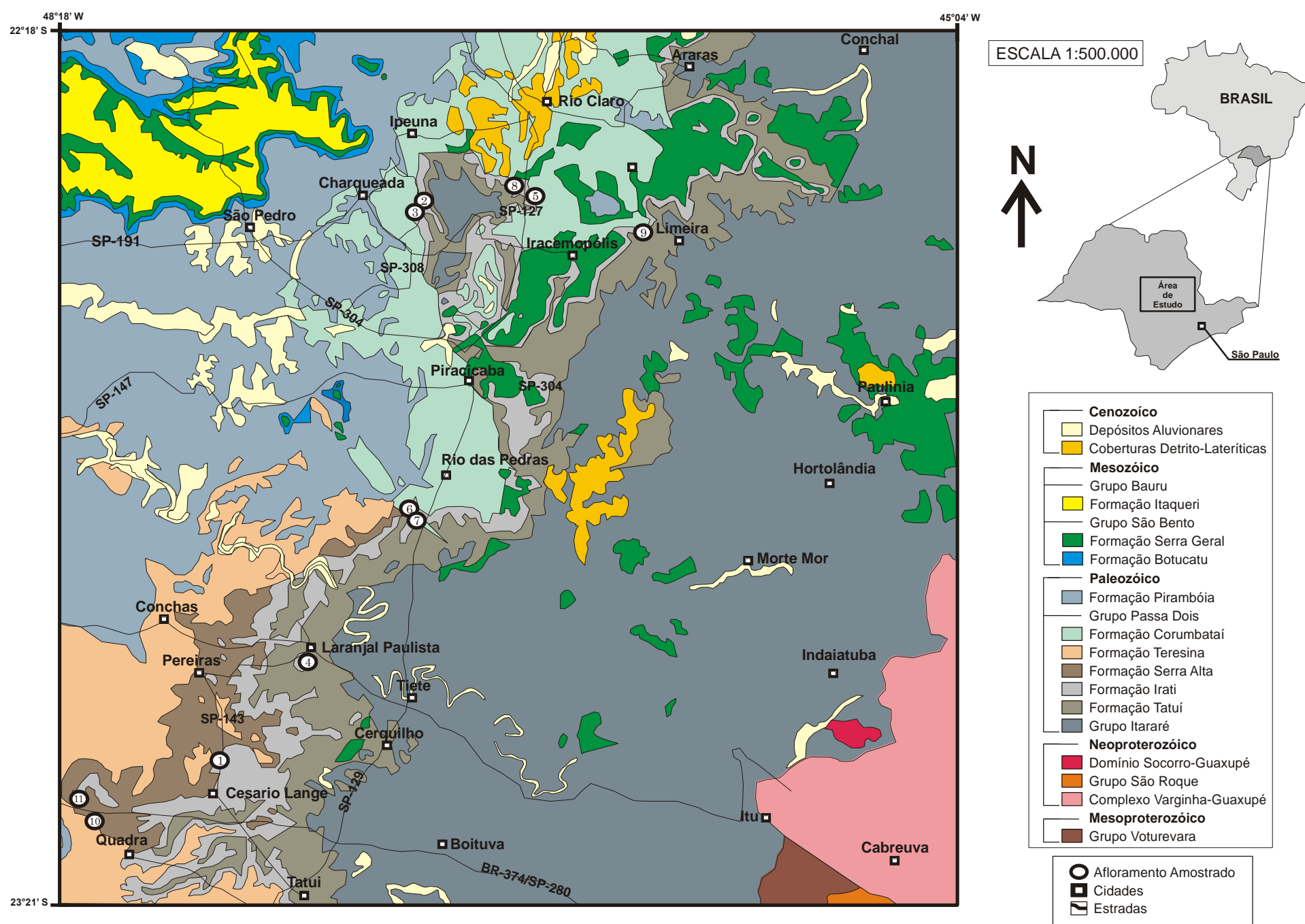

Figura 2.14: Mapa de localização dos afloramentos estudados no Estado de São Paulo. Modificado de Perrota et al. (2005). 

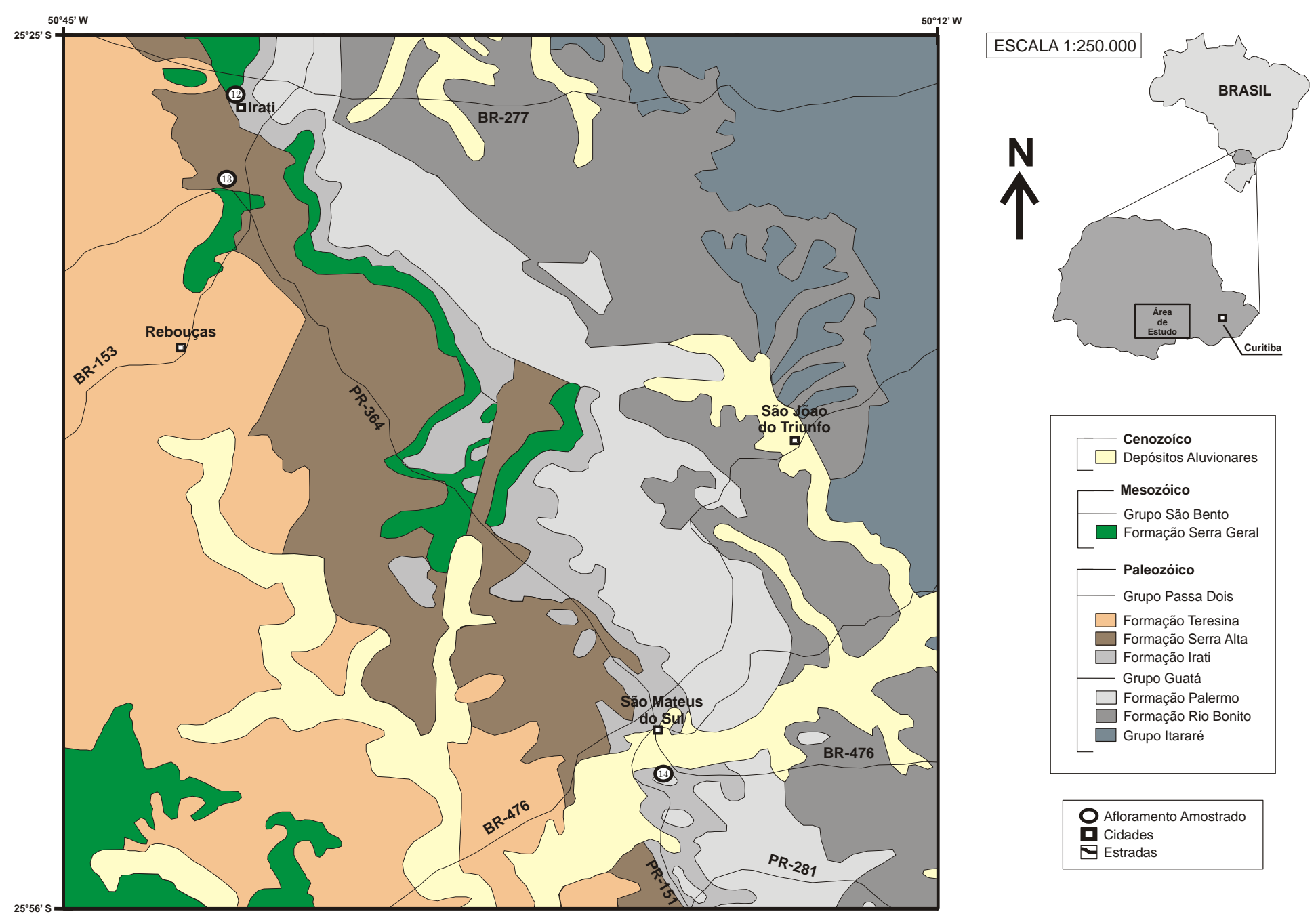

\begin{tabular}{l} 
O Afloramento Amostrado \\
Cidades \\
Estradas \\
\hline
\end{tabular}

Figura 2.15: Mapa de localização dos afloramentos estudados no Estado do Paraná. Modificado de Perrota et al. (2004). 


\section{FUNDAMENTAÇÃO TEÓRICA: Inclusões fluidas}

\subsection{Considerações gerais}

Inclusões fluidas são pequenos volumes de fluidos aprisionados dentro de cavidades ou irregularidades eventualmente presentes na superfície dos cristais, durante processos de cristalização, recristalização ou cicatrização de fraturas, constituindo, desse modo, verdadeiros testemunhos das soluções presentes em alguma etapa da evolução geológica. As inclusões fluidas (Figura 3.1) armazenam informação sobre temperaturas, pressões e composições de fluidos antigos. Tais informações são obtidas por meio de observações petrográficas, análises microtermométricas e geoquímicas do conteúdo das inclusões (Roedder, 1977, 1982, 1984; Goldstein \& Reynolds, 1994).

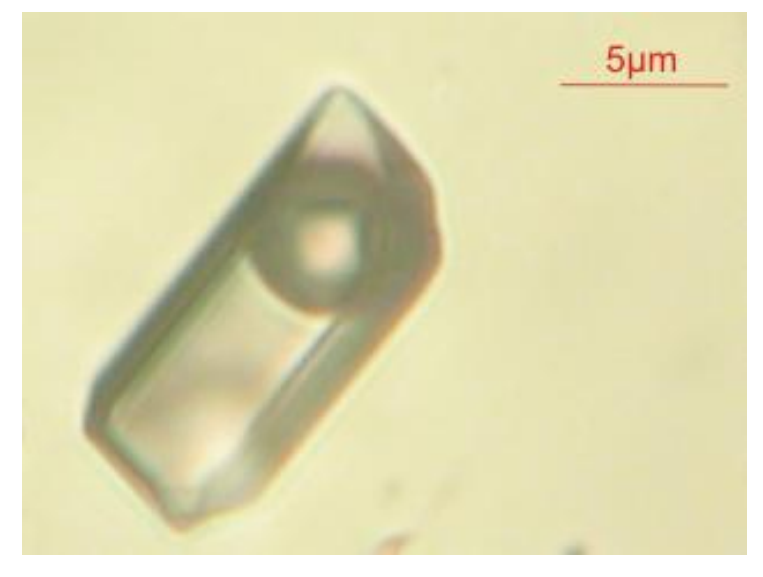

Figura 3.1: Exemplo de inclusão fluida.

O estudo de inclusões fluidas permite determinar as condições físico-químicas vigentes durante a cristalização ou recristalização do mineral que as contém ou, ainda, em eventos geológicos posteriores à formação destes minerais (Roedder, 1984; Fuzikawa, 1985; Shepherd et al., 1985). Possibilita, ainda, estimar as condições atuantes na formação de um depósito mineral, na constituição de rochas magmáticas, na diagênese das rochas sedimentares e no metamorfismo das rochas.

Esse método tem sido aplicado na sedimentologia, estratigrafia e pesquisa de petróleo, uma vez que fornece informações diretas acerca dos fluidos diagenéticos e permite a 
determinação da origem de grãos detríticos, a identificação do caminho percorrido pelo óleo e de suas possíveis rochas armazenadoras. Também é amplamente utilizado para estudar a história diagenética de um pacote sedimentar e estabelecer a evolução das condições de pressão e temperatura das bacias sedimentares petrolíferas (Roedder, 1984; Prezbindowski e Larese, 1987; Goldstein \& Reynolds, 1994; Munz, 2001).

Roedder (1984) e Shepherd et al. (1985), entre outros, discutem que as inclusões fluidas podem ser classificadas como primárias, pseudo-secundárias e secundárias, de acordo com sua origem e modo de ocorrência. As inclusões primárias fornecem informações sobre os fluidos existentes e as condições vigentes durante o processo de cristalização do mineral hospedeiro, enquanto que, as secundárias possibilitam as mesmas informações só que relacionadas a eventos posteriores (Roedder 1984, Fuzikawa 1985, Shepherd et al. 1985). As inclusões fluidas também podem ser classificadas de acordo com o número de fases presentes à temperatura ambiente $\left(\sim 25^{\circ} \mathrm{C}\right)$; as inclusões são denominadas de monofásicas quando apresentam somente uma fase líquida ou gasosa; bifásicas quando contém duas fases, sejam elas líquida+gasosa, líquida+sólida, líquida+líquida ou sólida+gasosa; trifásicas quando exibem uma combinação de três fases, sendo as mais comuns as de líquido+líquido+gás e de líquído+gás+sólido; e polifásica ou multifásica quando são constituídas por quatro ou mais fases.

Após o aprisionamento de uma inclusão, esta pode sofrer algumas modificações, tais como: o aparecimento de uma fase vapor - que resulta da maior contração do líquido em relação ao mineral hospedeiro com o resfriamento; a formação de sólidos de saturação quando as soluções originais possuem altas salinidades; o escape de fluidos (leakage); a crepitação e o estrangulamento das inclusões (necking down) (Roedder, 1982, 1984).

O termo escape de fluidos (leakage) é usado para incluir movimentos de materiais para dentro ou fora da inclusão após o aprisionamento original sendo mais facilmente observado na presença de planos de inclusões vazias em amostras que foram fraturadas depois do aprisionamento do fluido. Feições de escape são comumente visualizadas como finos prolongamentos dispostos nas bordas ou ao redor da inclusão. Tanto o escape de fluidos quanto a crepitação ocorrem devido à diferença entre a pressão interna da inclusão e a pressão externa que diminui. Se a diferença entre as pressões interna e externa atingir valores extremos, pode ocorrer a crepitação (explosão) das inclusões com escape de fluidos resultando em cavidades escurecidas vazias (Roedder e Skinner, 1968; Roedder, 1977, 1984). 
O estrangulamento (necking down) advém dos processos de dissolução e recristalização do mineral hospedeiro, quando este é parcialmente solúvel na solução aprisionada. Por meio deste processo, inclusões com feições irregulares e grandes dimensões, na ocasião do aprisionamento, podem exibir, atualmente, regiões estranguladas. Adicionalmente, também podem sofrer subdivisões em inclusões menores de morfologias mais regulares. Caso o necking down seja desenvolvido após o aparecimento da fase vapor, serão formadas novas inclusões com diferentes proporções volumétricas entre as fases e que, consequentemente, apresentarão densidades e composições distintas entre si, não representativas do fluido original (Roedder, 1982, 1984).

As modificações posteriores ao aprisionamento podem interferir nas características originais das inclusões e nos resultados obtidos a partir delas, causando alterações nas relações volumétricas entre as fases e nas temperaturas de homogeneização. Portanto, o estudo microtermométrico dessas inclusões deve ser evitado, pois os valores obtidos podem não ser representativos do evento de interesse.

\section{2- Microscopia petrográfica}

A análise de inclusões fluidas requer estudo petrográfico inicial para reconhecimento de assembleias de inclusões nos minerais de interesse. Com a utilização do microscópio petrográfico é possível estudar as propriedades das inclusões fluidas tais como sua morfologia, o número de fases existentes à temperatura ambiente, as razões volumétricas entre as fases, suas dimensões e a origem e forma de ocorrência, permitindo sua classificação em primárias, secundárias ou pseudo-secundárias.

A simples caracterização petrográfica das inclusões fluidas pode fornecer diversas informações acerca da composição dos fluidos e das suas condições de aprisionamento. Por exemplo, inclusões de hidrocarbonetos poderiam ser facilmente confundidas com inclusões aquosas. Entretanto, a maneira mais eficaz de distingui-las é observá-las quando expostas à radiação de luz ultravioleta, pois as inclusões de hidrocarboneto apresentam fluorescência, enquanto as aquosas não (Munz, 2001; Coelho, 2005).

A descrição petrográfica de inclusões de hidrocarboneto é realizada com base na cor de fluorescência, no número de fases à temperatura ambiente a nas suas proporções relativas. A cor da fluorescência e as proporções entre as fases refletem informações sobre sua composição e maturidade. Segundo Munz (2001) a proporção de líquido e vapor em uma inclusão de hidrocarboneto à temperatura ambiente varia em função da composição e da 
densidade do fluido. Inclusões compostas por gás condensado terão uma tendência de possuir grandes bolhas de fase vapor à temperatura ambiente que podem preencher grande parte da inclusão, enquanto inclusões compostas por óleo volátil ou black oil possuem tendência de exibir fase vapor na forma de pequenas bolhas, sendo a fase líquida predominante.

\subsection{Microtermometria}

A microtermometria é uma técnica não-destrutiva que consiste na determinação das temperaturas de mudanças de fases que ocorrem nos componentes das inclusões fluidas sob condições controladas de aquecimento e/ou resfriamento das amostras.

Para que possa ser aplicada a microtermometria, os fluidos das inclusões devem ser representativos da solução presente no momento do evento de interesse, seja durante a cristalização do mineral hospedeiro (inclusões primárias), seja em eventos posteriores (inclusões secundárias); sua composição e densidade devem permanecer constantes desde seu aprisionamento e quando ocorrerem variações nesses parâmetros, estas devem ser passíveis de identificação durante a fase de petrografia das inclusões fluidas (Weisbrod et al., 1976).

De modo geral, o equipamento utilizado na microtermometria consiste de platinas acopladas a microscópios petrográficos, as quais permitem o resfriamento e o aquecimento da amostra, de um container com nitrogênio líquido e um sistema de controle e registro da temperatura. $\mathrm{O}$ resfriamento atinge até $-180^{\circ} \mathrm{C}$ através da circulação de nitrogênio líquido em canais localizados no interior da platina, e seu aquecimento alcança até $+600^{\circ} \mathrm{C}$ por meio de uma resistência disposta internamente, na região central da platina. A visualização de todas as etapas de aquecimento e resfriamento é executada no microscópio petrográfico.

Durante o procedimento são efetuadas as medidas das temperaturas de mudanças de fase de todos os componentes da inclusão (Figura 3.2). Essas temperaturas, quando comparadas com a de sistemas já estudados experimentalmente e que possuam equações de estado conhecidas, fornecerão informações sobre a densidade, composição e salinidade dos fluidos, bem como permitirão estimar as temperaturas e pressões do seu aprisionamento.

$\mathrm{Na}$ etapa de aquecimento, a amostra que inicialmente estava à temperatura ambiente é progressivamente aquecida até que os componentes das inclusões se transformem em um único fluido homogêneo; essa temperatura é denominada temperatura de homogeneização (TH). Inclusões bifásicas constituídas por uma fase líquida e outra vapor, podem homogeneizar-se de duas maneiras, a primeira pelo desaparecimento de uma das fases pela crescente diminuição de seu volume (homogeneização para o estado líquido ou vapor), e a 
segunda pelo súbito desaparecimento da separação entre as duas fases (homogeneização para o estado crítico). Após as devidas correções, a temperatura de homogeneização representa a temperatura de aprisionamento do fluido na inclusão ou da formação do mineral se a inclusão é primária, e a temperatura alcançada em eventos posteriores se a inclusão é secundária (Fuzikawa, 1985) ou, ainda, a temperatura representativa de reequilíbrios de inclusões primárias (Larson et al., 1983; Prezbindowski \& Larese, 1987; Goldstein \& Reynolds, 1994).

Durante a etapa de resfriamento, a amostra que anteriormente estava à temperatura ambiente é resfriada até que todos os fluidos das inclusões congelem. Uma vez congelados, a temperatura da amostra vai aumentando até que as inclusões retornem à temperatura ambiente, através da troca de calor com o meio. Nessa trajetória de retorno à temperatura ambiente, são efetuadas as medidas da temperatura eutética e da temperatura de fusão do gelo, no caso das inclusões aquosalinas. A temperatura eutética, corresponde ao momento em que é formada a primeira gota de líquido na solução aquosa congelada, enquanto a temperatura de fusão do gelo registra o momento de derretimento do último cristal de gelo no interior da inclusão fluida. A temperatura eutética (início da fusão) fornece informação sobre a composição do fluido aprisionado, e o ponto de fusão da solução aquosa (fusão final) permite, por sua vez, a determinação da sua salinidade.
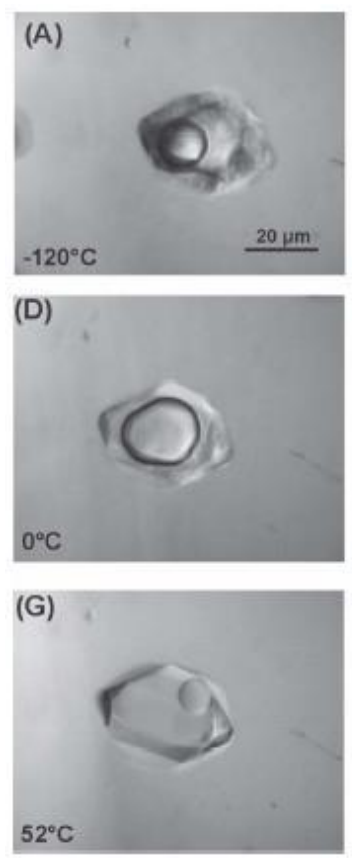
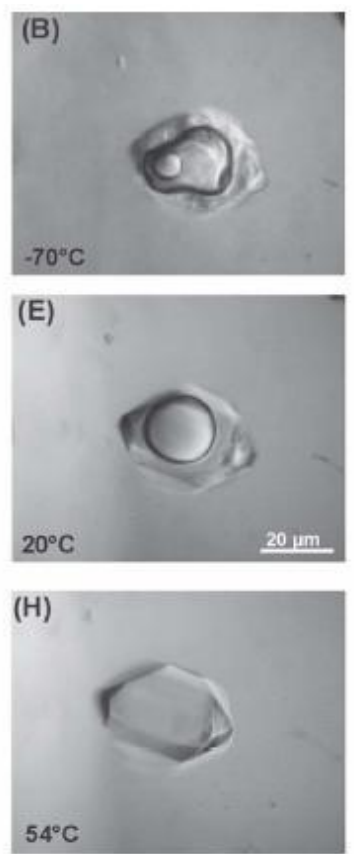
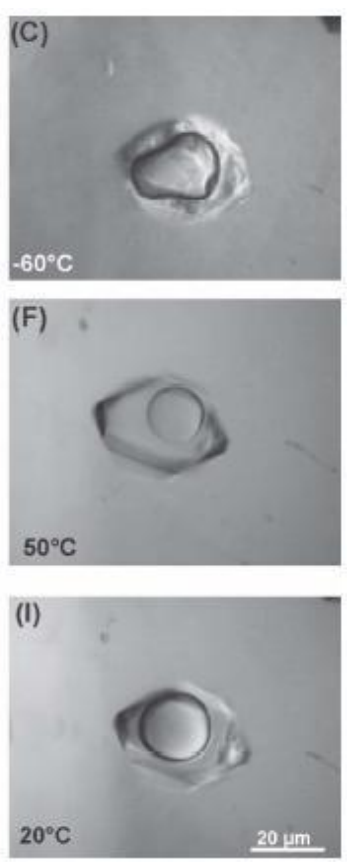

Figura 3.2: Sequencia de resfriamento-aquecimento de uma inclusão fluida aquosa. Etapa de resfriamento $(\mathrm{E} \rightarrow \mathrm{A}):(\mathrm{A})=$ congelamento $\left(-120^{\circ} \mathrm{C}\right)$ tendo-se gelo + vapor; $(\mathrm{E})$ inclusão a $20^{\circ} \mathrm{C}$ submetida a um rápido resfriamento; (D) reaquecimento, a fusão do gelo está próxima, indicando a salinidade do fluido. Etapa de aquecimento $(\mathrm{E} \rightarrow \mathrm{I})$ : $(\mathrm{H})$ temperatura de homogeneização na fase líquida $\left(\mathrm{Th}=54^{\circ} \mathrm{C}\right)$, (I) após o aquecimento a bolha de vapor volta ao seu diâmetro original à $20^{\circ} \mathrm{C}$ Extraído de Coelho (2005). 


\section{Capitulo 4}

\section{MATERIAIS E MÉTODOS}

\subsection{Descrição de afloramentos e coleta de amostras}

Entre março de 2009 e julho de 2011 foram realizadas cinco atividades de campo que possibilitaram a caracterização litológica, estratigráfica e estrutural dos afloramentos visitados, além da coleta de amostras para descrições petrográficas, estudos de inclusões fluidas e teores de carbono orgânico total (COT) e enxofre.

\subsection{Petrografia de seções delgadas}

Foram descritas 12 seções delgadas ao microscópio óptico para caracterização textural e mineralógica das rochas da Formação Irati e duas seções delgadas correspondentes aos basaltos associados ao magmatismo Serra Geral.

\subsection{Análises de carbono orgânico total (COT) e enxofre (S)}

O procedimento de preparação das amostras de folhelhos consistiu nas etapas de desagregação física da amostra e no ataque com ácido clorídrico para liberar o carbono inorgânico (na forma de carbonato). As amostras foram fragmentadas com o uso de prensa hidráulica e pulverizadas no moinho de ágata. Em seguida, cada $10 \mathrm{~g}$ de amostra foi atacada com $100 \mathrm{ml}$ de ácido clorídrico a 10\% durante 24 horas. Após esse período, as amostras foram abundantemente filtradas com água destilada e secas na estufa com temperatura de $50^{\circ} \mathrm{C}$, por 48 horas. Posteriormente as amostras foram novamente pesadas e uma alíquota de $1,5 \mathrm{~g}$ de cada amostra foi encaminhada para análise.

A preparação das amostras foi realizada no Laboratório de Tratamento de Amostras (LTA) e no Laboratório de Sedimentologia, pertencentes ao Instituto de Geociências da USP. As análises de carbono orgânico total (COT) e enxofre foram realizadas pela Central Analítica do Instituto de Química da USP. Os equipamentos utilizados foram o CHN 2400 PerkinElmer e o Espectrômetro Ótico de Emissão Atômica com Plasma Indutivamente Acoplado (ICP-AES Radial), Marca Spectro, Modelo Arcos - SOP, para determinações de carbono orgânico total e enxofre, respectivamente. 
Ao todo, foram adquiridos 38 dados de carbono orgânico total (COT) e de enxofre em amostras de folhelhos das formações Irati (35) e Corumbataí (1) e siltitos da Formação Serra Alta (2).

\subsection{Estudo de inclusões fluidas}

\subsubsection{Amostras utilizadas para estudo}

As amostras apropriadas para estudos microtermométricos consistem em seções delgadas, com espessura geralmente superior a $30 \mu \mathrm{m}$, que receberam polimento nas suas duas faces (bipolidas). A espessura das seções polidas varia em função das características do mineral hospedeiro, tais como a transparência do mineral, e das dimensões das inclusões.

Para aquisição de dados microtermométricos foi necessário que a amostra fosse descolada da lâmina de vidro. Esse processo de descolamento foi efetuado mergulhando a amostra em recipiente contendo acetona em solução. Contudo, em alguns casos foi necessário mergulhar a amostra em xilol para seu completo descolamento.

Uma vez descolada da lâmina de vidro, a amostra foi fragmentada em pequenos pedaços, de modo a apresentar dimensões que possibilitassem sua colocação no porta-amostra localizado no centro da platina acoplada ao microscópio petrográfico. Nesse fragmento da amostra, foi denominado "campo" à porção da amostra escolhida para observação e aquisição de dados microtermométricos.

Um campo adequado para estudo microtermométrico é aquele que contém quantidade razoável de inclusões que possuam características representativas do total da lâmina. Suas dimensões devem permitir tanto a observação das mudanças de fase dos constituintes da inclusão como o registro das respectivas temperaturas onde elas ocorrem durante os processos de resfriamento e aquecimento. Além disso, as inclusões selecionadas não devem apresentar feições indicativas de modificações posteriores ao aprisionamento.

Para descrição petrográfica e estudo microtermométrico das inclusões fluidas, foram selecionados um total de 49 campos. Destes, 20 campos correspondem ao Grupo I, oito ao Grupo II e 21 ao Grupo III. A subdivisão das inclusões em grupos foi baseada na localidade da amostragem e no mineral hospedeiro. O Grupo I corresponde a inclusões fluidas encontradas em veios de calcita espática, amostras 08-A a 08-I, coletadas na frente de lavra da Mineração Calcário Rocha Fértil, situada no município de Cesário Lange (SP) (ponto 1). Nos grupos II e III, as amostras foram coletadas em afloramento situado às margens do Ribeirão 
Paraíso, nas proximidades do distrito de Paraisolândia, município de Charqueada (SP) (ponto 2), sendo que o Grupo II compreende as inclusões fluidas presentes nos veio de calcita espática (amostra MS-2B) e o Grupo III corresponde a inclusões hospedadas em veio de quartzo (amostra MS-2D).

É importante esclarecer que no caso do Grupo I, a partir de cada amostra de mão foi confeccionada uma lâmina bipolida, totalizando 8 lâminas, sendo que destas, 5 foram selecionadas para estudo (08-B, 08-E, 08-F, 08-G, 08-H e 08-I). Para estudo do Grupo II, foram preparadas quatro lâminas e os campos estudados foram identificados como C1 a C8. Por sua vez, para o estudo do Grupo III, foram confeccionadas cinco lâminas (L1 a L5) e seus campos foram identificados por uma sigla que continha o número da lâmina e do campo, por exemplo, L2-C1corresponde ao campo1 da lâmina L2.

\subsubsection{Microscopia petrográfica}

A etapa de descrição petrográfica, além de fundamental para a caracterização das inclusões fluidas presentes na amostra, foi documentada na forma de desenhos e fotomicrografias, e foi decisiva na escolha dos campos nos quais foram obtidos os dados microtermométricos.

Outra etapa importante da petrografia foi aquela efetuada com auxílio de luz ultravioleta, pois possibilitou o reconhecimento de inclusões fluidas compostas por hidrocarbonetos, uma vez que estas se tornam fluorescentes sob tais circunstâncias.

O microscópio utilizado no Laboratório Petrografia Sedimentar do Instituto de Geociências foi o microscópio petrográfico Zeiss Axioplan, com a câmera CCD Sony Color Vídeo e analisador de imagem QWIN 550.

\subsubsection{Microtermometria}

Nos campos de inclusões fluidas hospedadas em cristais de calcita espática, foi efetuada primeiramente a etapa de aquecimento e posteriormente a de resfriamento. Já nos campos de inclusões fluidas hospedadas em cristais de quartzo, foi adotado o procedimento contrário, com a etapa de resfriamento sendo realizada antes da etapa de aquecimento. Esse procedimento baseou-se em informações presentes em Goldstein \& Reynolds (1994). Esses autores mostram que, por ser o carbonato um mineral mais frágil, de menor dureza, pode ocorrer o estiramento das paredes da inclusão com o resfriamento, o que é causado pelo acréscimo de volume da solução aquosa quando congelada. Esse acréscimo de volume 
ocasiona uma modificação na densidade original, o que é registrado por um acréscimo nas temperaturas de homogeneização total. Desse modo, quando nos carbonatos o resfriamento é realizado antes do aquecimento da inclusão, os dados referentes a este último processo, ou seja, as temperaturas de homogeneização obtidas poderão ser incorretas.

A etapa de resfriamento pôde ser repetida tantas vezes se fez necessário para a obtenção dos dados, pois o repetido resfriamento não ocasiona alterações nas composições dos fluidos das inclusões que possam comprometer a confiabilidade dos dados adquiridos. Contudo, a repetição da etapa de aquecimento não foi adotada, uma vez que o repetido aquecimento pode também causar estiramento, com consequente aumento nas temperaturas de homogeneização das inclusões fluidas, além de vazamentos com escape de fluidos das mesmas.

A mudança de fase associada à temperatura eutética foi muitas vezes sutil e de difícil visualização. Como o ponto eutético corresponde à primeira mudança contínua na textura do fluido, relacionada com a formação da primeira gota de líquido a partir do sistema congelado, trata-se de uma medida menos precisa. Apesar da temperatura dessa mudança de fase ter sido registrada com precisão de uma casa decimal após a vírgula, sabe-se que a incerteza é de cerca de dois ou três graus, pois uma vez que o registro da temperatura é efetuado no momento em que se tem certeza da mudança de fase, e muitas vezes essa certeza é indicativa que a temperatura eutética já passou, essa medida apresenta erro de aproximadamente dois ou três graus Celsius para mais. Entretanto, a informação mais relevante é saber se os resultados encontram-se dentro das faixas de valores estabelecidos experimentalmente para determinado sistema aquossalino.

A metaestabilidade, apresentada por algumas inclusões fluidas, causa um decréscimo no valor da temperatura do ponto eutético. Esse decréscimo será maior quanto maior a pressão interna gerada pelo desaparecimento da bolha com o resfriamento e aumento de volume causado pelo congelamento da solução aquossalina. Portanto, em algumas inclusões os valores obtidos podem não representar exatamente os pontos eutéticos reais. No entanto, essas imprecisões não podem ser precisamente determinadas, devido à dificuldade na obtenção de um controle exato das modificações das pressões internas ocasionadas pelo desaparecimento da bolha com o resfriamento. Algumas inclusões fluidas, em especial as com salinidades mais baixas, possuíam apenas uma ligeira mudança contínua de textura nas temperaturas eutéticas, tornando sua determinação mais difícil e necessitando da repetição de sua medida. 
Todas as temperaturas de fusão do gelo tiveram que ser corrigidas utilizando o valor de $-1,8^{\circ} \mathrm{C}$ como fator de correção obtido com a calibração do equipamento. Esse fator foi determinado medindo-se a temperatura de fusão do gelo de água pura deionizada. Durante as medições, ao invés da fusão do gelo acontecer na temperatura esperada de $0^{\circ} \mathrm{C}$, ocorreu alternadamente nas temperaturas de $1,7^{\circ} \mathrm{C}$ e $1,8^{\circ} \mathrm{C}$, mostrando a necessidade de correção dos dados. Em várias inclusões fluidas, especialmente as de salinidade mais baixa, os ensaios para obtenção das medidas das temperaturas de fusão do gelo tiveram que ser repetidos inúmeras vezes, devido ao seu comportamento metaestável.

A aquisição dos dados microtermométricos foi efetuada em uma platina de resfriamento/aquecimento CHAIXMECA, modelo MTM 85, tendo sido realizada no Laboratório de Inclusões Fluidas do Instituto de Geociências da USP e contou com a orientação da Dra. Rosa Maria da Silveira Bello, responsável pelo laboratório. O aplicativo Bulk, do pacote FLUIDS1 (Bakker, 2003), foi utilizado para o cálculo das salinidades.

Ao todo foram obtidos dados microtermométricos em 732 inclusões fluidas hospedadas em veios de calcita espática e quartzo que seccionam a Formação Irati. 


\subsection{Descrição dos afloramentos estudados}

\subsubsection{Pedreira da Mineração Calcário Rocha Fértil (Ponto 1)}

A Mineração Calcário Rocha Fértil (inativa) está localizada no km 6 da estrada Cesário Lange-Pereiras, no município de Cesário Lange, São Paulo. Esta frente de lavra possui cerca de 25 metros de espessura (Figura 5.1A) e centenas de metros de extensão.

A partir da base em direção ao topo do afloramento, ocorre camada com pelo menos meio metro de espessura composta por uma intercalação de calcário dolomítico cinza claro maciço e níveis milimétricos de folhelho cinza escuro (Figura 5.1B), recoberta por ritmito de camadas centimétricas a decimétricas levemente onduladas de folhelho cinza escuro betuminoso, intercaladas com camadas decimétricas de rochas carbonáticas maciças de cor cinza claro (Figura 5.1C). O ritmito apresenta aproximadamente 16 metros de espessura e as camadas de rochas carbonáticas e de folhelhos que o compõe, tornam-se mais espessas em direção ao topo da sucessão e aparentam estar mais deformadas. O ritmito é recoberto por siltitos pastilhados de cor cinza da Formação Serra Alta, com cerca de 8 metros de espessura.

Concreções e sílex preto ocorrem em grande quantidade nos folhelhos e nas rochas carbonáticas, sendo que nestas últimas o silexito forma níveis milimétricos a centimétricos, por vezes com continuidade lateral de dezenas de metros.

Destaca-se a presença de fraturas de espessura milimétrica com direções NW-SE e NE-SW impregnadas por hidrocarbonetos e restritas às camadas de rochas carbonáticas (figuras 5.1D e 5.2). As fraturas que seccionam a Formação Irati ocorrem com espaçamento decimétrico a métrico, possuem continuidade vertical métrica e apresentam duas direções principais NE-SW e NW-SE (predominante) (Figura 5.3). Algumas destas fraturas também estão impregnadas por hidrocarbonetos. Veios de calcita espática com um a dois centímetros de espessura, discordantes do acamamento e, por vezes, impregnados por hidrocarbonetos, seccionam camadas de rochas carbonáticas. Esses veios foram selecionados para estudo de inclusões fluidas (Grupo I). A ocorrência de hidrocarboneto é também perceptível na forma de manchas nas rochas carbonáticas (figuras 5.1E e 5.1F). Essa ocorrência não é homogênea, mas apresenta certa continuidade lateral. 

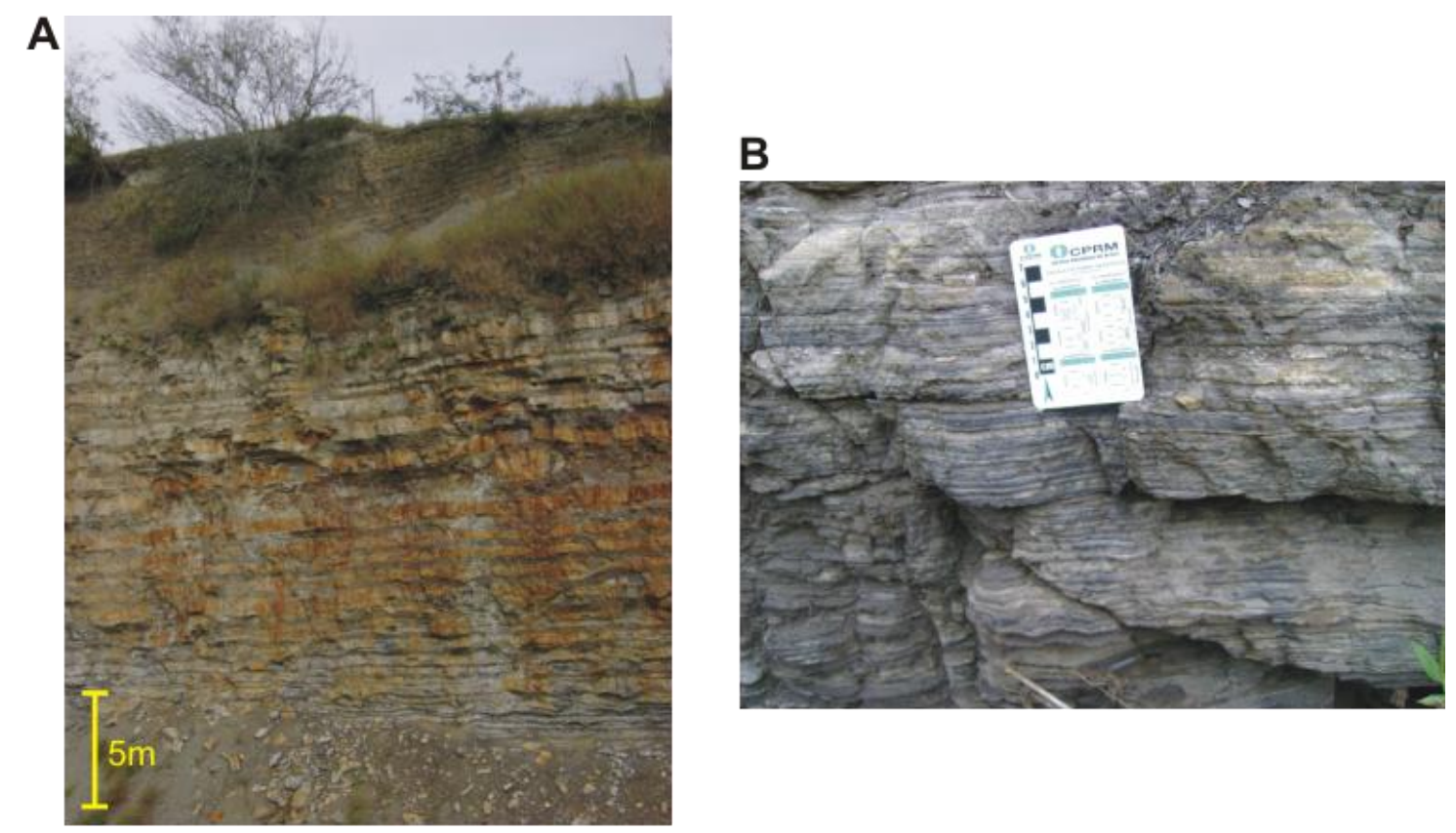

C

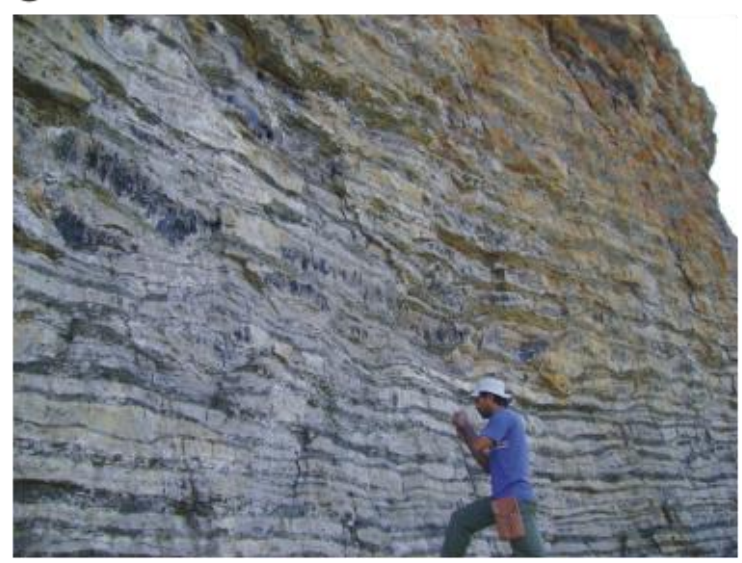

D

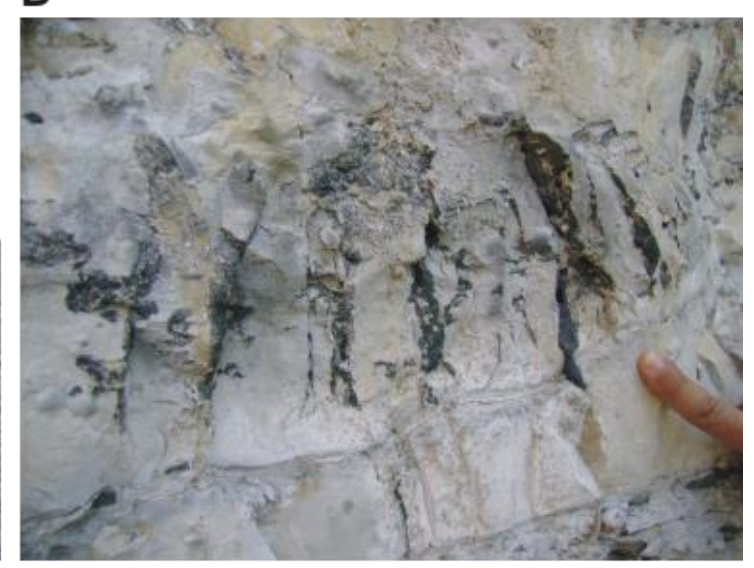

E
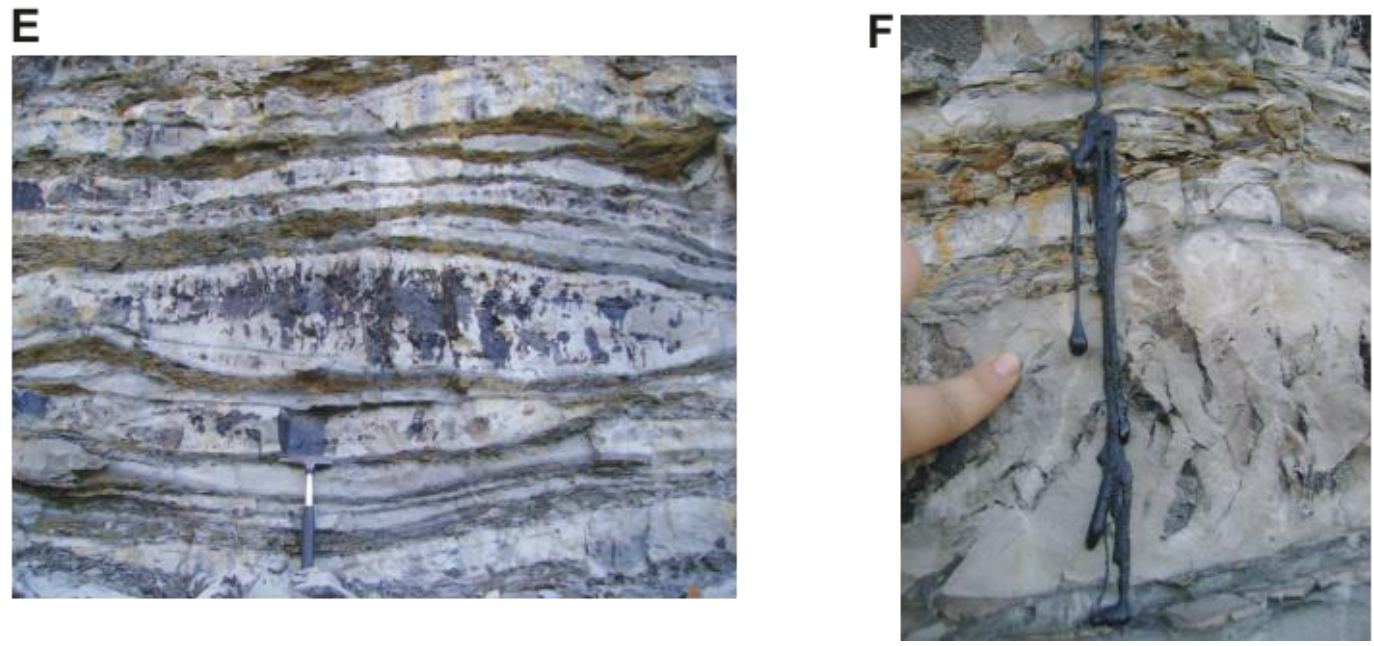

Figura 5.1: (A) Vista geral do afloramento. (B) Camada basal com intercalação delgada de rochas carbonáticas e folhelhos. (C) Ritmito de camadas de rochas carbonáticas e folhelhos. (D) Fraturas milimétricas impregnadas por hidrocarboneto. (E) e (F) Exudação de óleo viscoso sobre calcário dolomítico. Mineração Calcário Rocha Fértil, Cesário Lange (SP). 


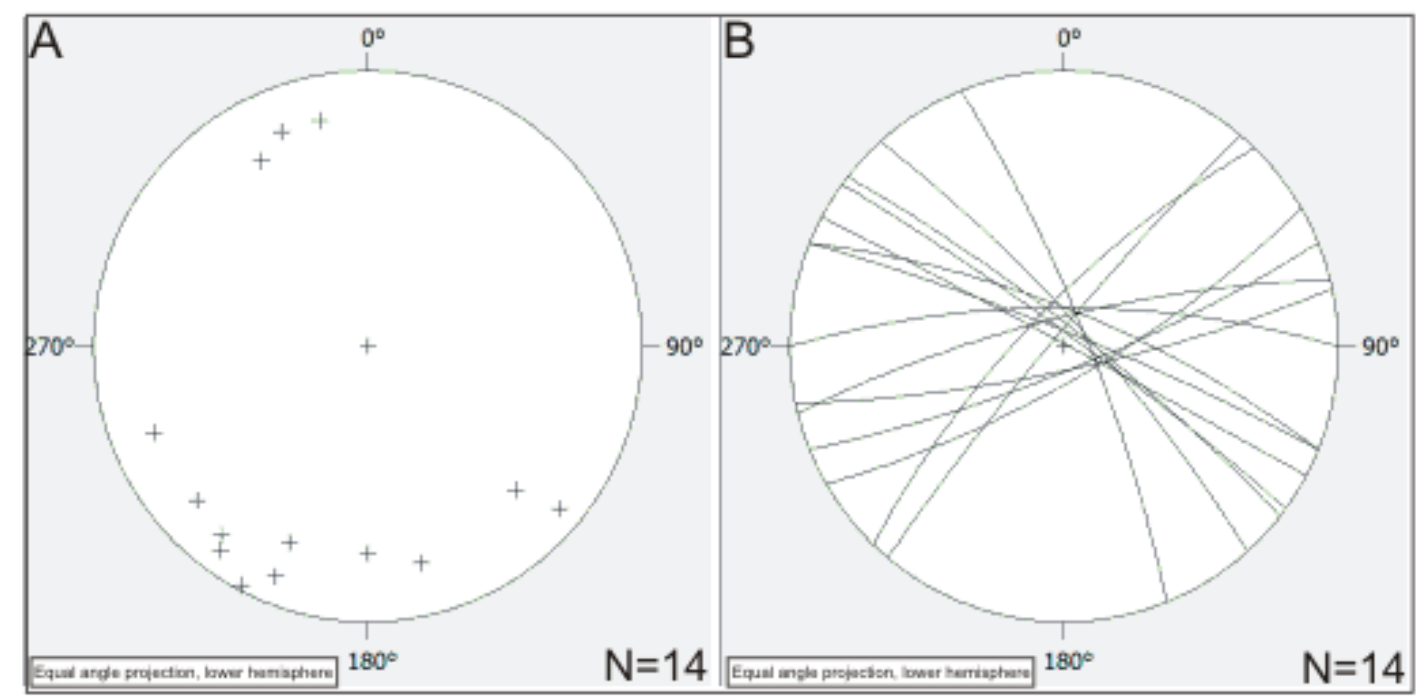

Figura 5.2: Estereogramas referentes às famílias de fraturas milimétricas impregnadas por hidrocarbonetos e restritas às camadas de calcário na Mineração Calcário Rocha Fértil, Cesário Lange (SP). (A) e (B) Projeções planares das fraturas no hemisfério inferior.

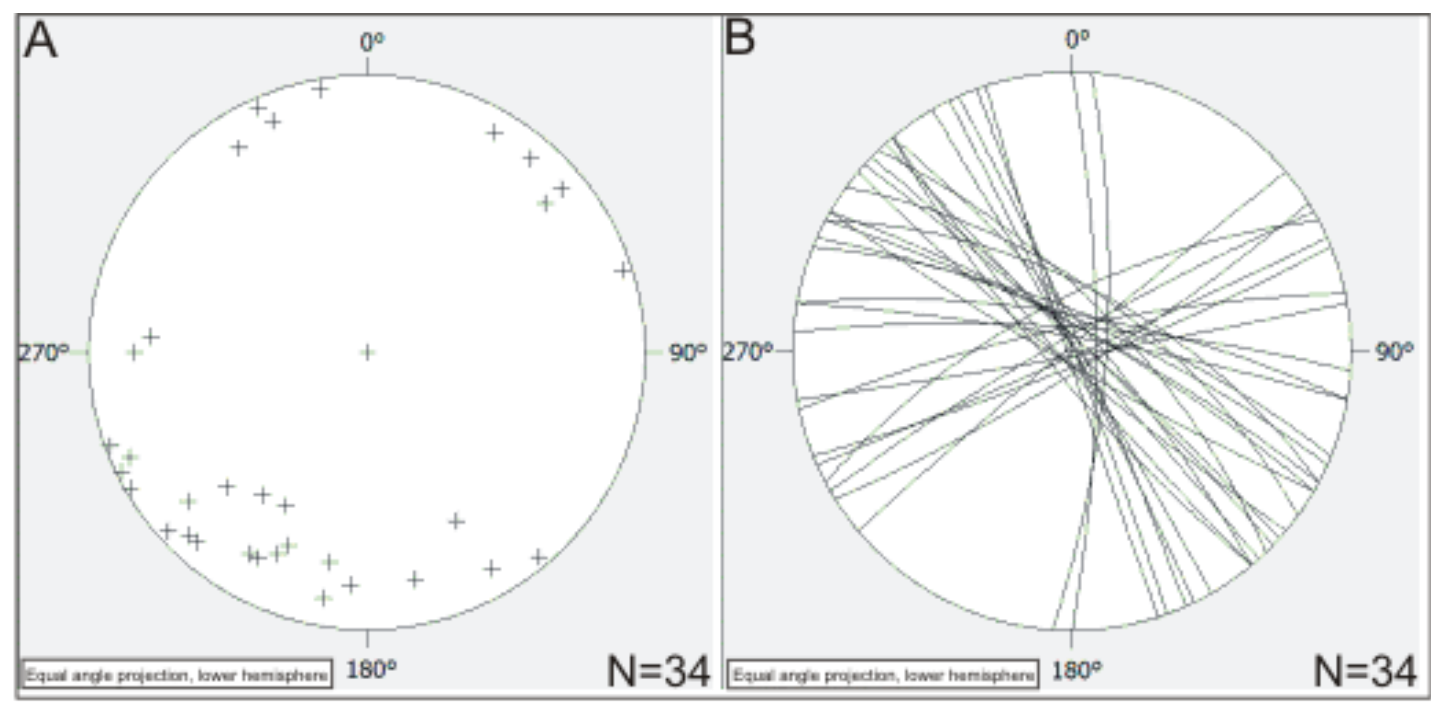

Figura 5.3: Estereogramas referentes às famílias de fraturas na Mineração Calcário Rocha Fértil, Cesário Lange (SP). (A) e (B) Projeções planares das fraturas no hemisfério inferior. 


\subsubsection{Afloramento da margem esquerda do Ribeirão Paraíso (Ponto 2)}

Este afloramento está situado na margem esquerda do Ribeirão Paraíso, nas proximidades do distrito de Paraisolândia, município de Charqueada, São Paulo. A exposição apresenta cerca de 5 metros de espessura e corresponde a Formação Irati (Figura 5.4A).

O afloramento consiste da base para o topo, de silexito basal de coloração cinza escura e forma dômica com espessura média de 20 centímetros, recoberto por camada de 50 centímetros de rocha carbonática laminada, deformada e de cor cinza (Figura 5.4B), seguida por recorrência de silexito dômico de coloração cinza escura a preta, com cerca de 40 centímetros de espessura (Figura 5.4C). Este, por sua vez, é recoberto por uma camada de aproximadamente um metro de espessura de folhelho cinza escuro a preto pastilhado, seguida por depósito de tálus de basalto com dois metros e meio de espessura (Figura 5.4D).

A camada de rochas carbonáticas apresenta veio de calcita fibrosa concordante com o acamamento deformado (veio onde foram estudadas inclusões fluidas pertencentes ao Grupo II), é seccionada por veios subverticais de quartzo (um destes veios foi escolhido para estudo das inclusões fluidas pertencentes ao Grupo III) e possui hidrocarbonetos de coloração marrom claro. No afloramento, uma fratura preenchida por veio de quartzo com atitude N142/82 aparentemente encontra-se seccionada por veio de calcita.

A camada de silexito localizada estratigraficamente acima da camada de rocha carbonática, forma domos com, em média, 40 centímetros de altura por 40 centímetros de diâmetro e exibe estrutura concêntrica e fraturas radiais preenchidas por quartzo fibroso, sacaróide ou geôdo concentradas na charneira do domo (figuras 5.4E, 5.5A e 5.5B). Veios de calcita são subordinados.

O pacote de folhelhos contém níveis de silexito que formam camadas contínuas paralelas ao acamamento ou dobras abertas descontínuas. Neste pacote também estão presentes níveis de calcita espática fibrosa concordantes com o acamamento com 0,5 a 1 centímetro de espessura (Figura 5.5C).

A Figura 5.6 apresenta o estereograma das famílias de fraturas que seccionam o afloramento. 


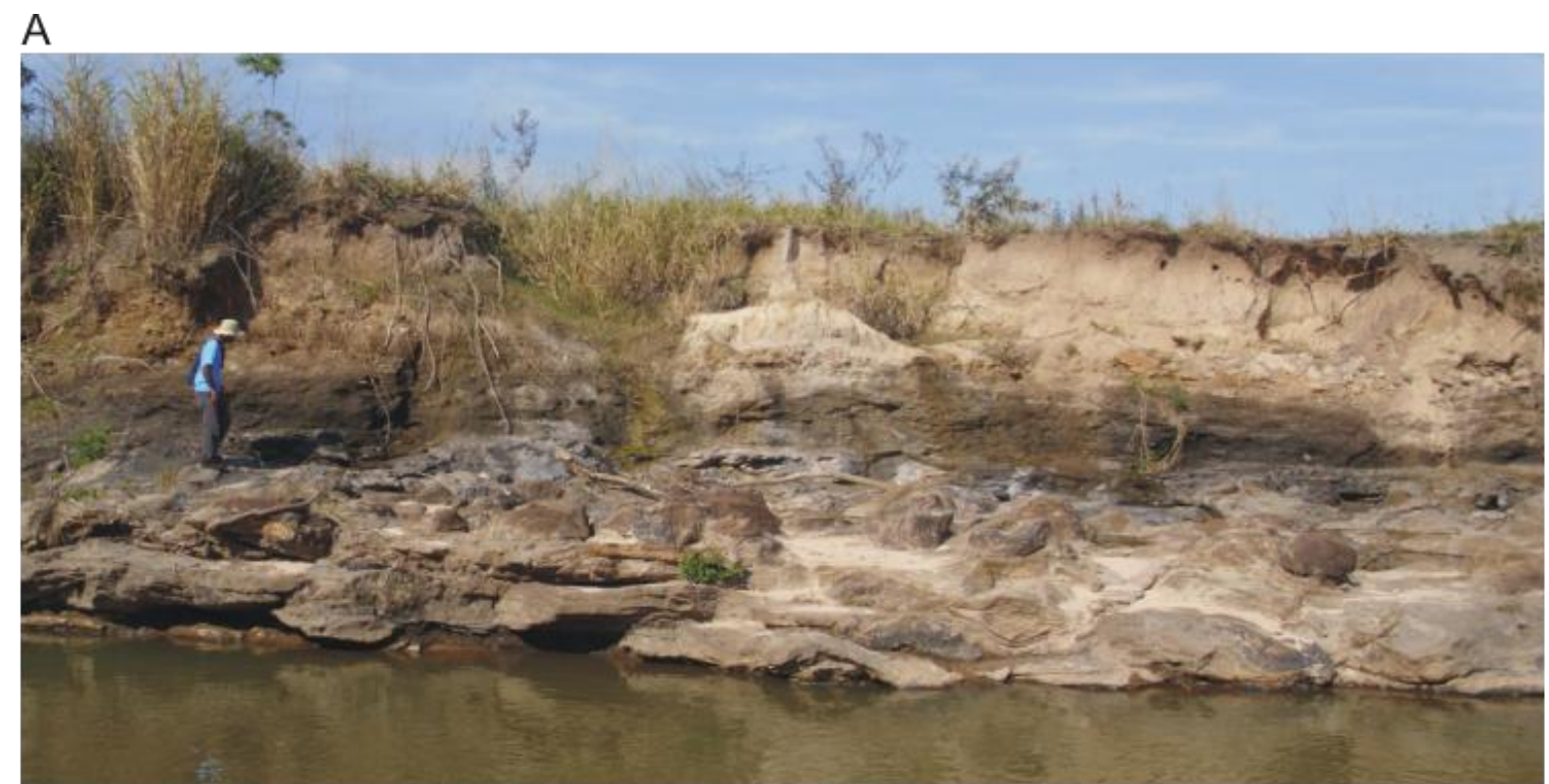

B

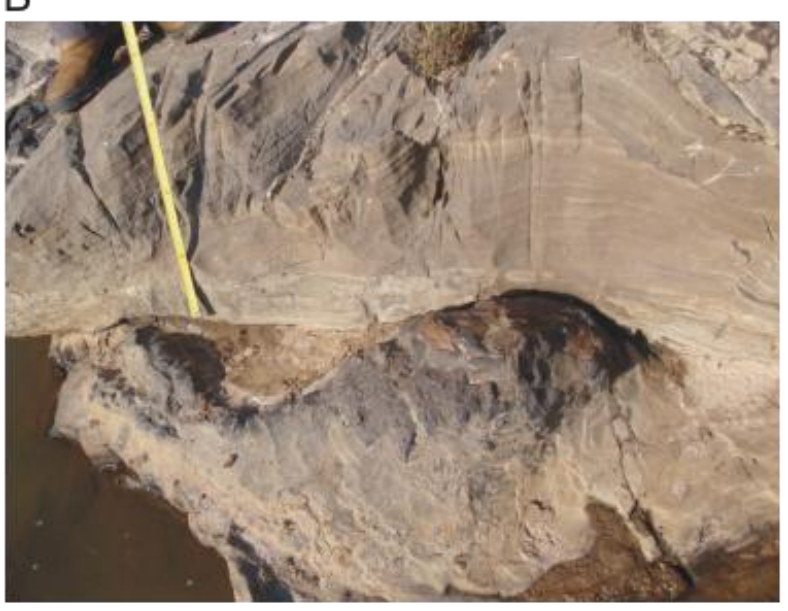

$\mathrm{D}$

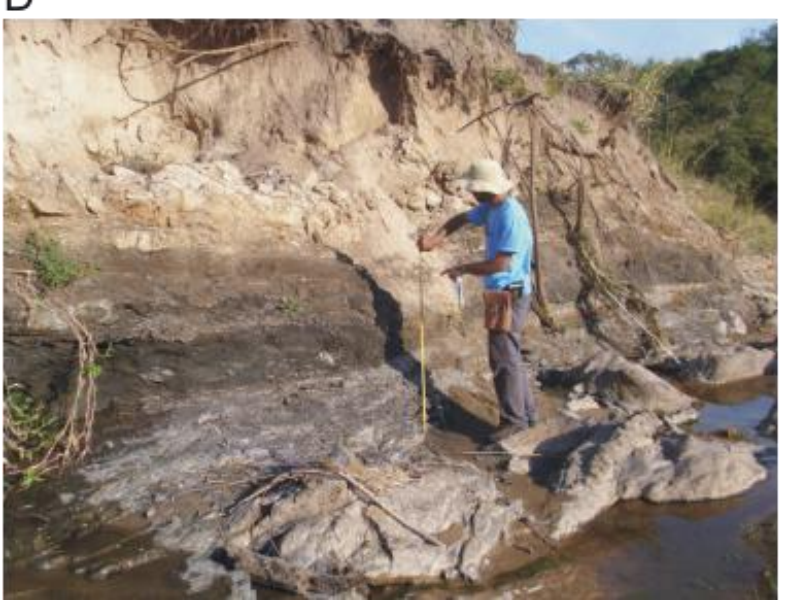

C

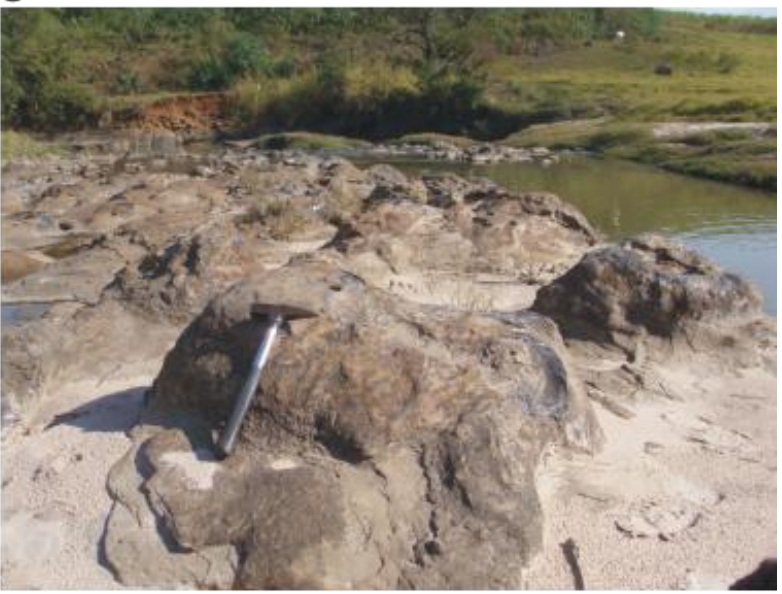

$\mathrm{E}$

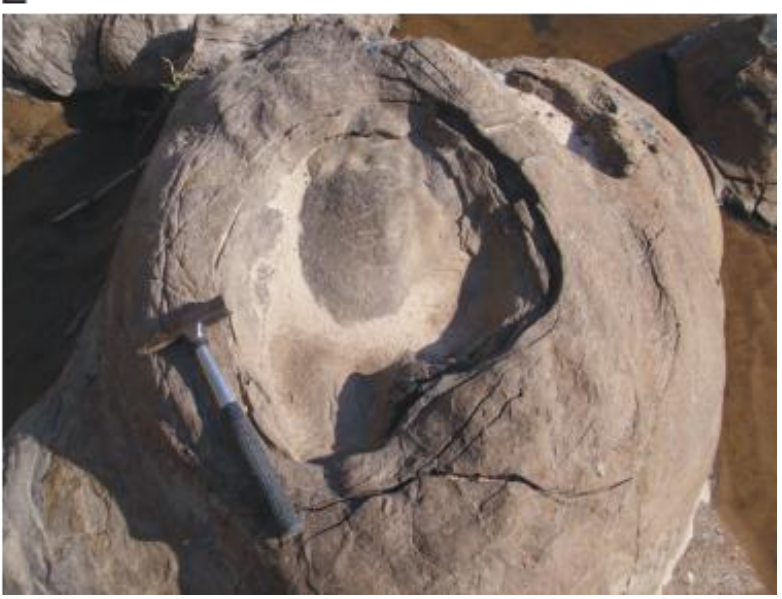

Figura 5.4: (A) Vista panorâmica do afloramento. (B) Camada de silexito basal recoberto por camada de rocha carbonática. (C) Nível de silexito dômico. (D) Camada de folhelhos recoberta por tálus de basalto. (E) Detalhe de domo de silexito seccionado por fraturas concêntricas e radiais. Afloramento nas margens do Ribeirão Paraíso, próximo ao distrito de Paraisolândia (Charqueada, SP). 

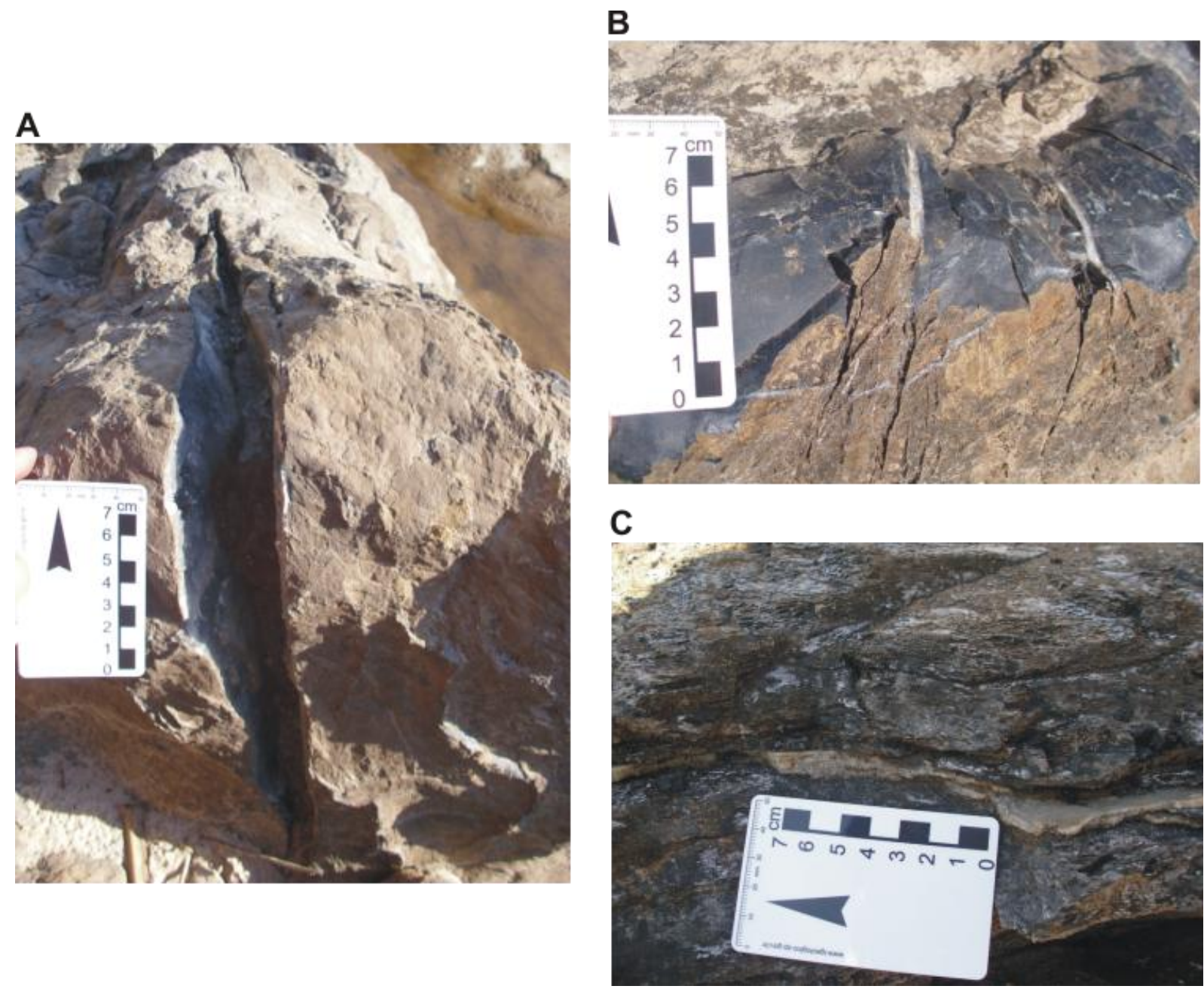

Figura 5.5: Exemplos dos veios presentes no afloramento. (A) Veio de quartzo seccionando a charneira do domo de silexito. (B) Veio de quartzo subvertical seccionando silexito. (C) Veio de calcita espática fibrosa concordante ao acamamento do folhelho. Afloramento nas margens do Ribeirão Paraíso, próximo ao distrito de Paraisolândia (Charqueada, SP).

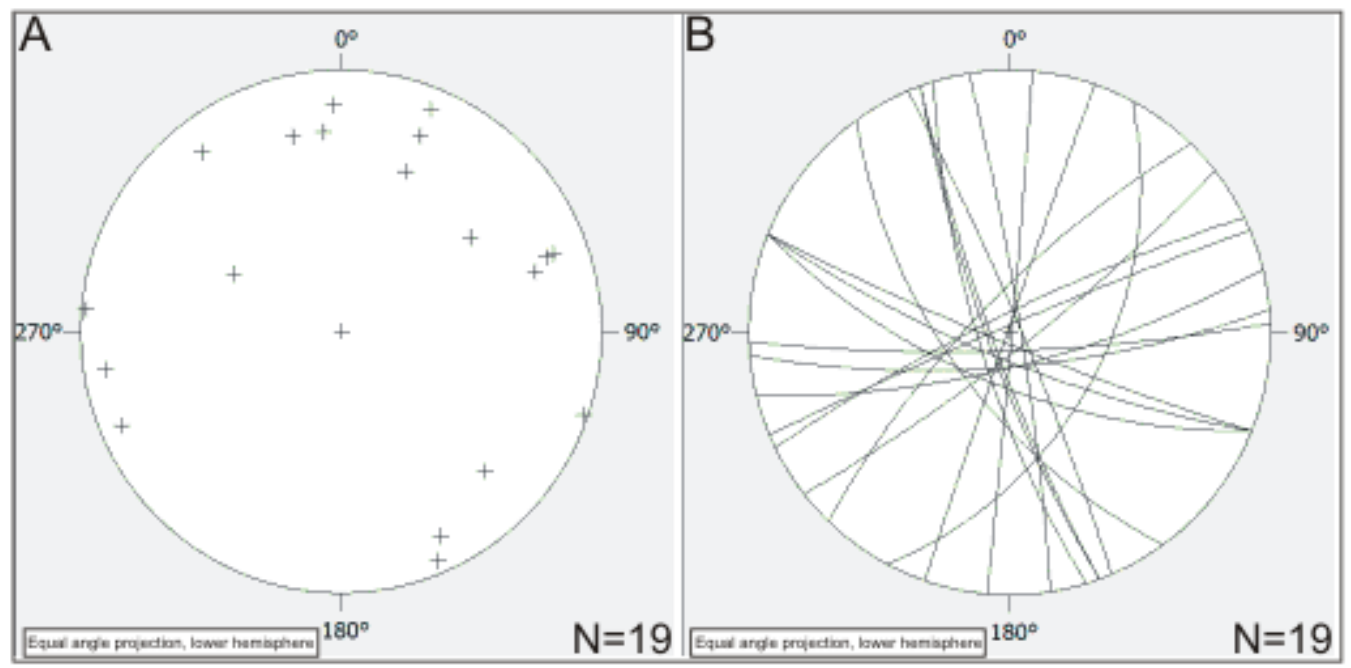

Figura 5.6: Estereogramas referentes às famílias de fraturas no afloramento situado na margem esquerda do Ribeirão Paraíso, próximo ao distrito de Paraisolândia (Charqueada, SP). (A) e (B) Projeções planares das fraturas no hemisfério inferior. 


\subsubsection{Afloramento na margem direita do Ribeirão Paraíso (Ponto 3)}

Afloramento localizado na margem direita do Ribeirão Paraíso, nas proximidades do distrito de Paraisolândia, município de Charqueada, São Paulo.

A exposição consiste de uma soleira de basalto com disjunções colunares de diâmetros entre 0,5 e 2 metros e espessura mínima de três metros (Figura 5.7A). A soleira, que se encontra fraturada, é recoberta por um pacote com cerca de 50 centímetros de espessura composto pela intercalação de camadas de folhelho, rocha carbonática e silexito (Figura 5.7B).

A

B
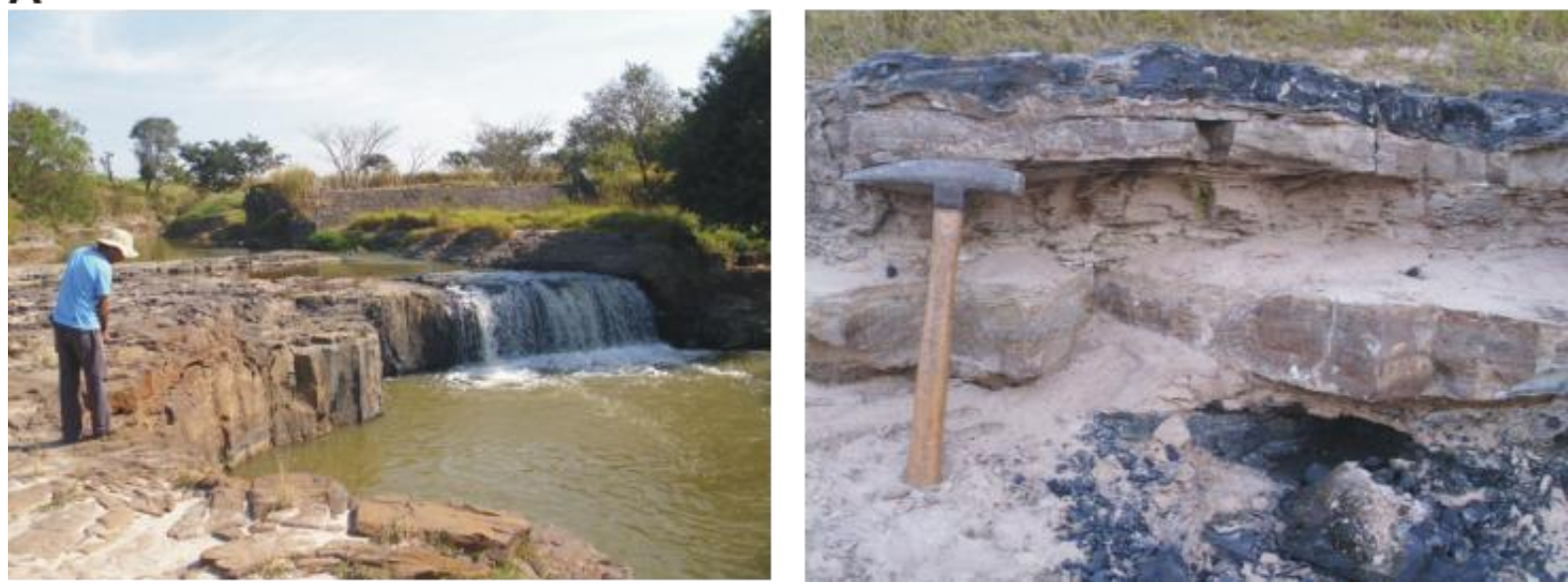

Figura 5.7: (A) Soleira de basalto. (B) Camadas de silexito, rochas carbonáticas e folhelhos recobrem a soleira. Afloramento nas margens do Ribeirão Paraíso, próximo ao distrito de Paraisolândia (Charqueada, SP).

\subsubsection{Soleira de basalto em Laranjal Paulista (Ponto 4)}

O afloramento está localizado em uma pedreira (inativa) situada nos arredores de Laranjal Paulista (SP). O afloramento possui cerca de 90 metros de espessura e centenas de metros de extensão (Figura 5.8).

A Formação Serra Geral possui composição predominantemente basáltica e encontrase muito fraturada, com direções principais de NW-SE e NE-SW. Há presença de apófise, situada no topo do afloramento. Próximo à apófise há um dique de basalto com direção NE $(306 / 50)$. 

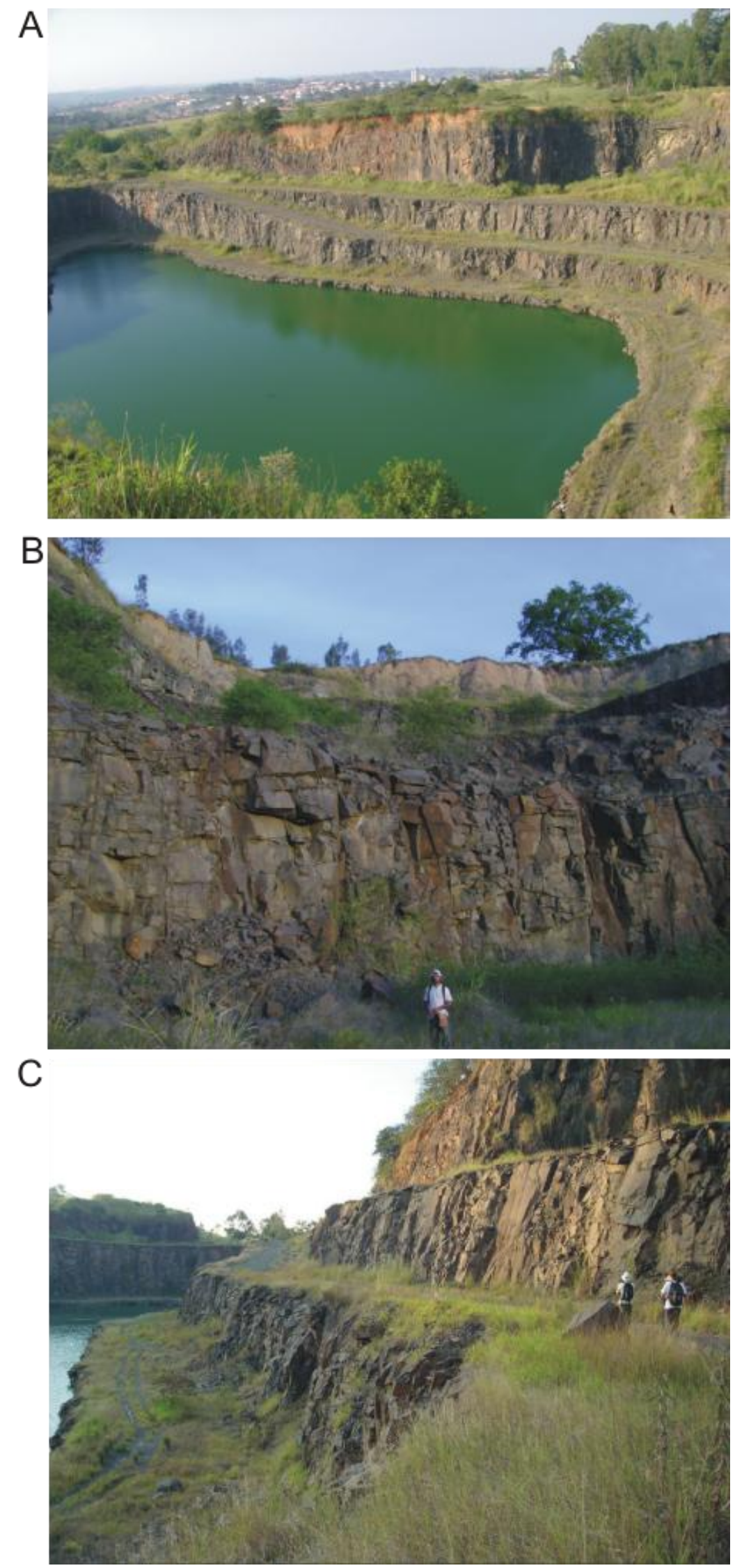

Figura 5.8: Soleira associada ao magmatismo Serra Geral. (A) Vista geral da pedreira (inativa). (B) Soleira de basalto em contato com siltito arenoso da Formação Corumbataí. (C) Soleira de basalto de aproximadamente 80 metros de espessura. Mineração em Laranjal Paulista (SP). 


\subsubsection{Pedreira da Mineração Partecal Partezani (Ponto 5)}

A pedreira da Mineração Partecal Partezani está localizada no km 10 da rodovia SP127, no município de Rio Claro, São Paulo. A exposição possui cerca de 10 metros de espessura e corresponde a Formação Corumbataí.

O afloramento (Figura 5.9) corresponde a um folhelho de coloração cinza a marrom, com presença de camadas arenosas milimétricas e níveis bioclásticos. Ocorrem fraturas curvilíneas com preenchimento de calcita com espessuras de 2 a 5 centímetros.

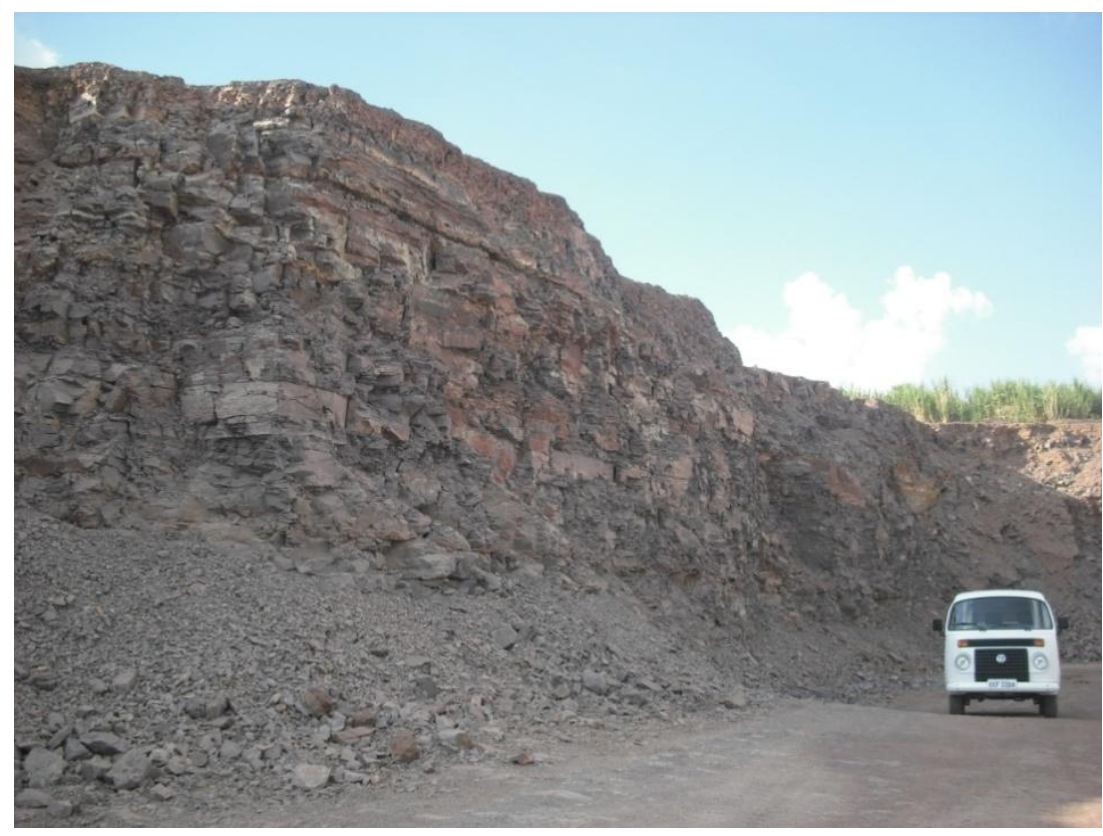

Figura 5.9: Vista geral do afloramento. Mineração Partecal Partezani, Rio Claro (SP).

\subsubsection{Pedreira da Mineração Amaral Machado (Ponto 6)}

A pedreira da Mineração Amaral Machado está localizada no km 57 da rodovia SP127, no município de Saltinho, São Paulo. A exposição possui aproximadamente 20 metros de espessura (Figura 5.10A) e é semelhante ao ponto 1.

A partir da base em direção ao topo do afloramento, é reconhecida camada com pelo menos dois metros e meio de espessura composta por uma intercalação de calcário dolomítico cinza claro laminado e níveis milimétricos de folhelho cinza escuro (Figura 5.10B). Esta camada é recoberta por ritmito de camadas centimétricas a decimétricas de folhelho cinza escuro intercaladas com camadas decimétricas de rochas carbonáticas maciças de cor cinza claro (Figura 5.10C). O ritmito apresenta aproximadamente 12 metros de espessura e as camadas de rochas carbonáticas e de folhelhos que o compõe tornam-se mais espessas em 
direção ao topo da sucessão. O ritmito é recoberto por um pacote de rochas intemperizadas com cerca de 6 metros de espessura.

As rochas carbonáticas que compõe o ritmito possuem concreções e níveis de sílex preto (Figura 5.10D) com até cinco centímetros de espessura e continuidade horizontal de dezenas de metros. Algumas camadas de rochas carbonáticas exibem feições de deformação dúctil similares a boudins. O folhelho apresenta cor cinza escura e odor de hidrocarboneto.

$\mathrm{O}$ afloramento é seccionado por fraturas com continuidade vertical métrica e espaçamento decimétrico a métrico e por falha com arrasto (Figura 5.10E) e rejeito vertical de aproximadamente três centímetros, o que indica deformação dúctil. A atitude 140/70 do plano de falha apresenta direção aproximadamente NE semelhante às fraturas preenchidas por óleo do ponto 1 .

O afloramento descrito pertence ao Membro Assistência (Formação Irati), por outro lado, o pacote superior que se encontra alterado, pode corresponder aos siltitos da Formação Serra Alta.

\subsubsection{Pedreira da Mineração de Calcário Vitti 1 (Ponto 7)}

A pedreira da Mineração de Calcário Vitti 1 está localizada no km 57 da rodovia SP127, no município de Saltinho, São Paulo. A sucessão de rochas exibe espessura de aproximadamente 25 metros (Figura 5.11A), a qual é semelhante aos afloramentos descritos nos pontos 1 e 5 .

A parte basal do afloramento corresponde à camada cuja espessura varia de um a três metros, composta por intercalação de calcário dolomítico cinza claro laminado e níveis milimétricos de folhelho cinza escuro. Esta intercalação é recoberta por ritmito de camadas centimétricas a decimétricas de folhelho cinza escuro intercaladas com camadas decimétricas de rochas carbonáticas maciças de cor cinza claro. O ritmito apresenta aproximadamente 15 metros de espessura, sendo que camadas de rochas carbonáticas e de folhelhos que o compõe tornam-se mais espessas em direção à porção superior do afloramento.

O afloramento é seccionado por dique subvertical de direção aproximadamente NW (figuras 5.11B, 5.11C) (atitudes N226/72 e N65/89), que apresenta auréola de metamorfismo de contato com a encaixante de dois a três centímetros de espessura. O dique apresenta também fraturas de resfriamento preenchidas por hidrocarboneto (Figura 5.11D).

Nessa sucessão pode-se reconhecer as camadas que compõe o Membro Assistência da Formação Irati. 


\section{A}

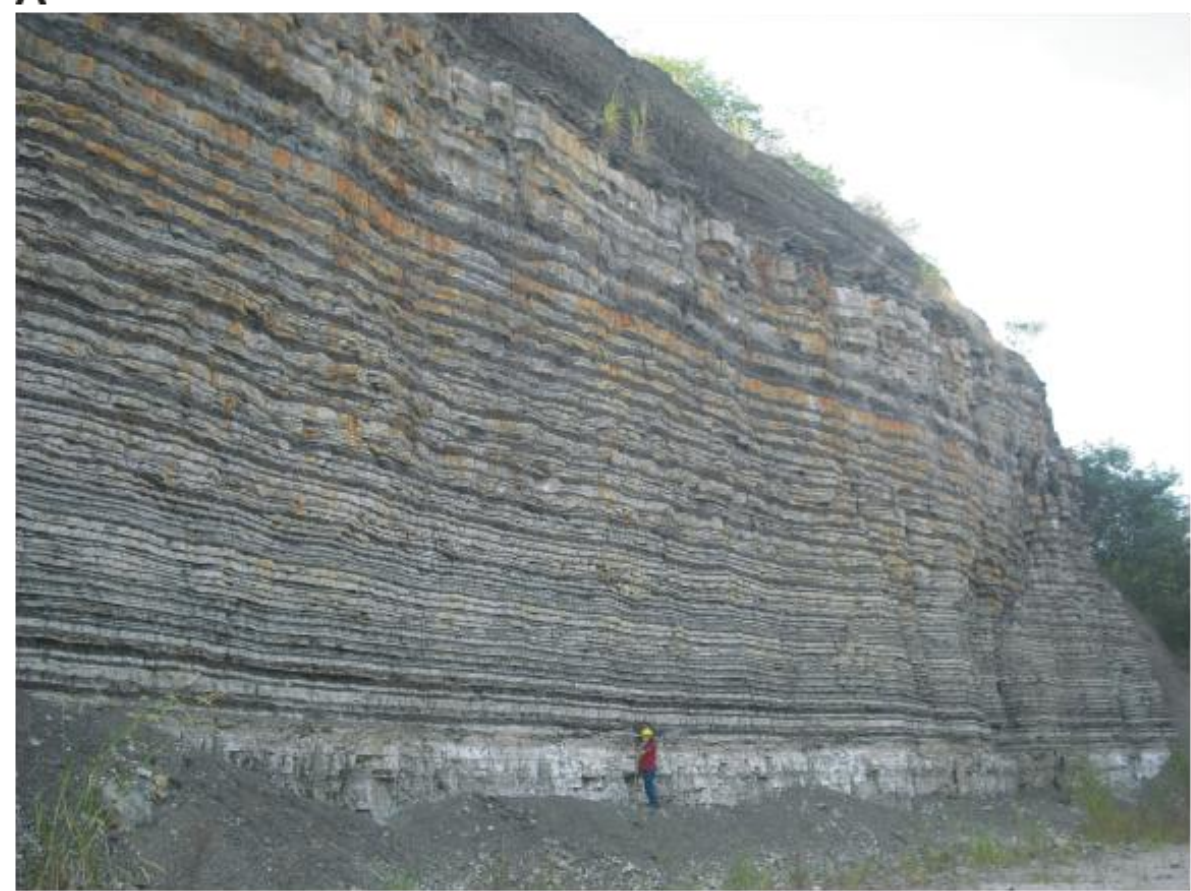

B

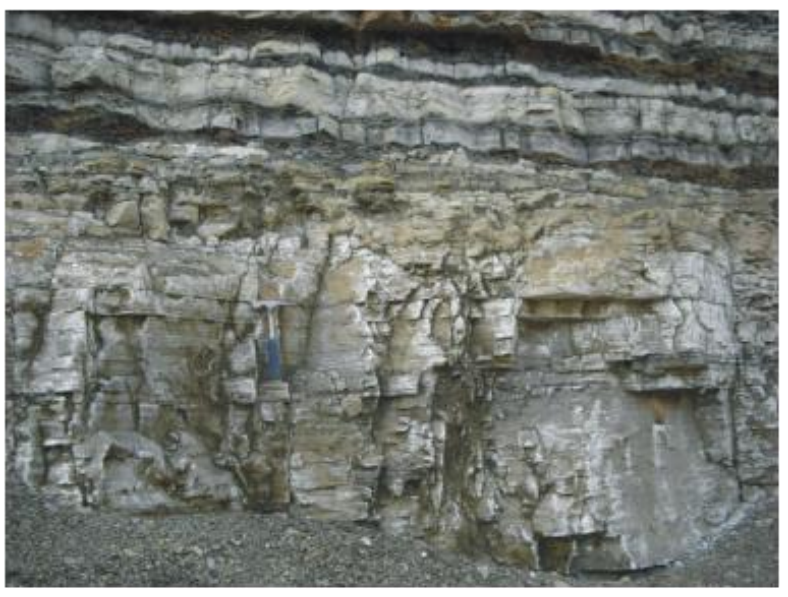

D

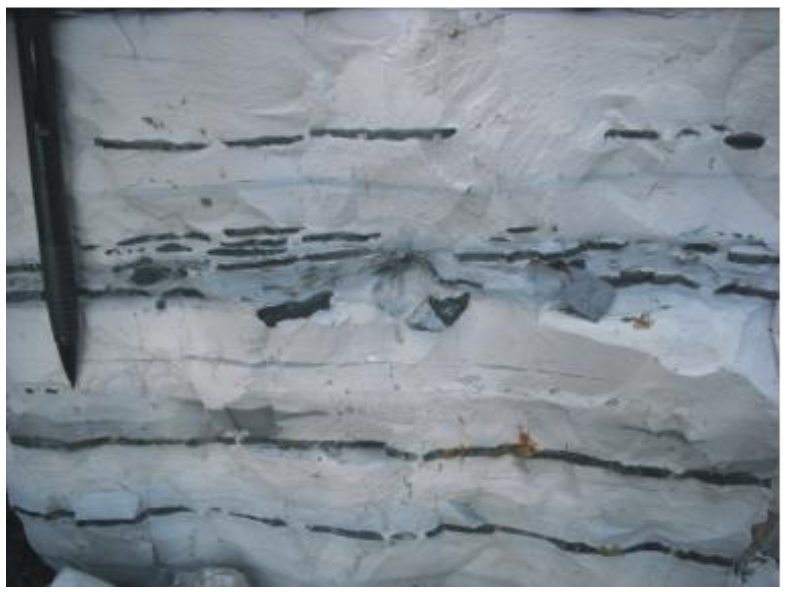

C

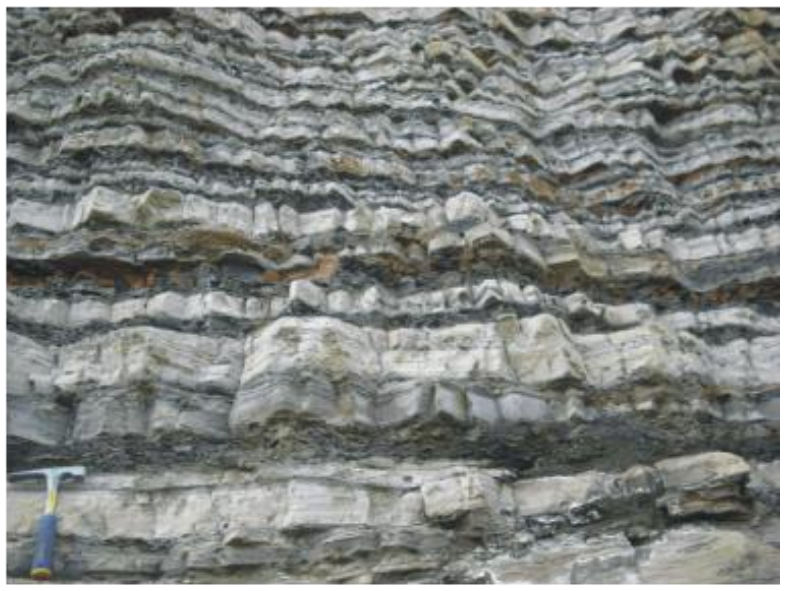

E

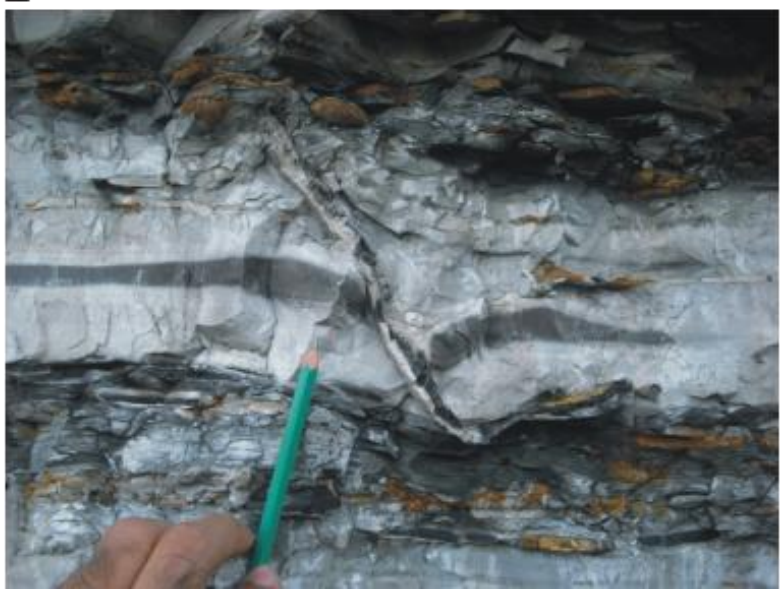

Figura 5.10: (A) Vista geral do afloramento. (B) Camada basal de rochas carbonáticas intercaladas com folhelhos. (C) Detalhe do ritmito de rochas carbonáticas e folhelhos. (D) Níveis de sílex preto. (E) Falha com arrasto. Mineração Amaral Machado, Saltinho (SP). 

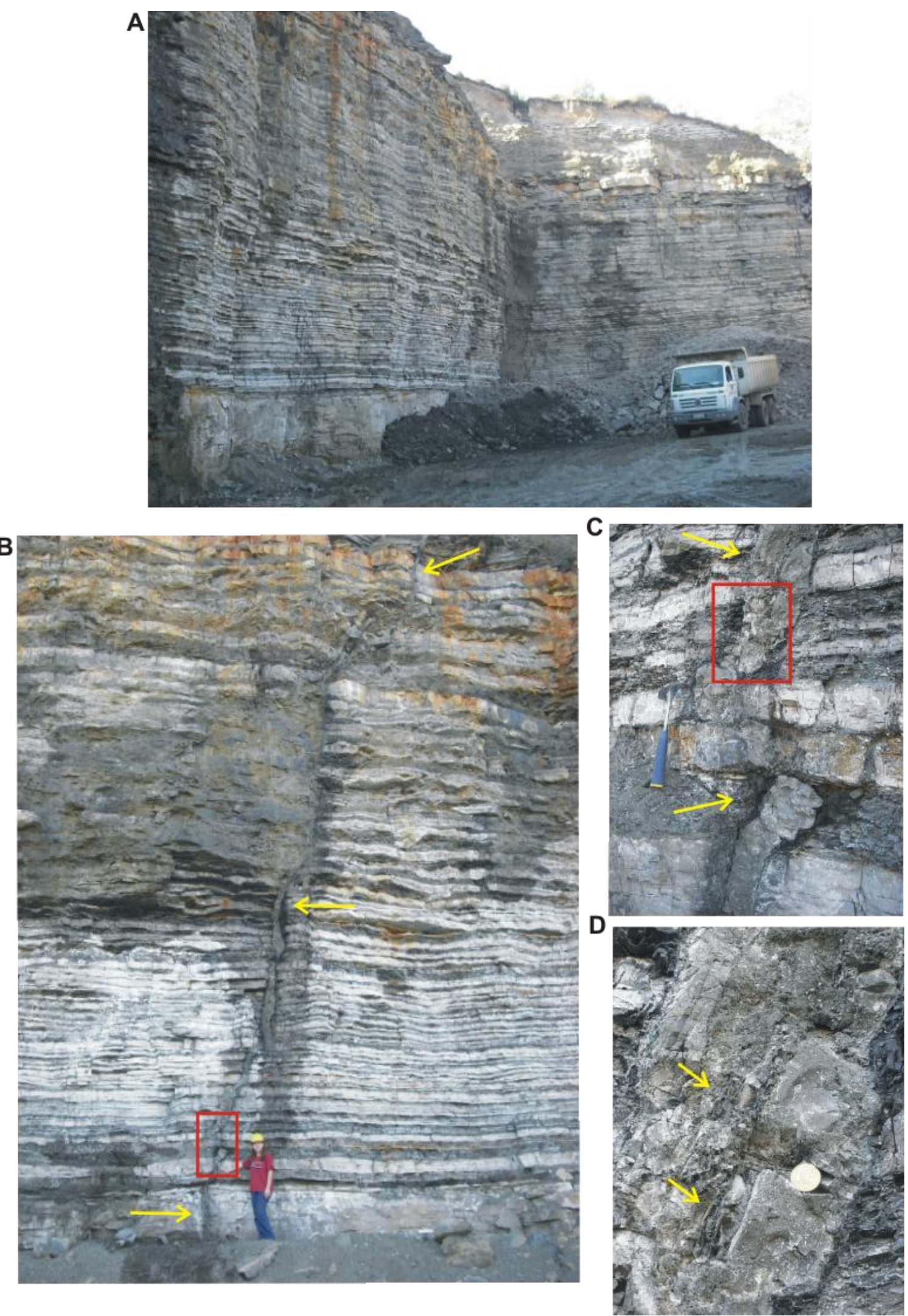

Figura 5.11: (A) Vista geral do afloramento. (B) Dique que secciona o afloramento. (C) Detalhe da foto anterior apresentando detalhe do dique. (D) Detalhe da foto anterior exibindo as fraturas de resfriamento. Mineração Vitti 1, Saltinho (SP). 


\subsubsection{Pedreira da Mineração de Calcário Vitti 2 (Ponto 8)}

A pedreira da Mineração de Calcário Vitti 2 (inativa) está situada no distrito Assistência (próxima à sub prefeitura) no município de Rio Claro. Esse afloramento está situado na localidade onde foi descrita a seção-tipo do Membro Assistência por Barbosa \& Gomes, em 1958. A exposição tem entre 15 e 20 metros de espessura (Figura 5.12A).

A porção basal do afloramento é composta por banco de rocha carbonática cinza escuro maciço a laminado (Figura 5.12B) com espessura aproximada de quatro metros. A laminação $(1 \mathrm{~mm}$ a $1 \mathrm{~cm})$ é paralela e aproximadamente plana. Neste banco, estão presentes concreções achatadas de sílex, níveis aparentemente bioclásticos e amígdalas preenchidas por óleo de coloração marrom. Ritmitos com intercalações de camadas de folhelhos e de rochas carbonáticas com espessuras centimétricas a decimétricas (Figura 5.12C) recobrem o banco de calcário. A espessura dessas camadas tende a aumentar em direção ao topo da seção. $\mathrm{O}$ topo do afloramento encontra-se alterado e recoberto por vegetação, de modo que não é possível identificar outras unidades geológicas. Fraturas subverticais abertas, sem preenchimento, com pequena continuidade vertical e espaçamento decimétrico a métrico, seccionam as rochas dessa localidade.

\subsubsection{Pedreira da Mineração Calcário Cruzeiro (Ponto 9)}

A pedreira da Mineração Calcário Cruzeiro está localizada na Avenida Cônego Manoel Alves, 2555, Parque Abílio Pedro, no município de Limeira, São Paulo. O afloramento apresenta excelente exposição com aproximadamente 60 metros de espessura, onde é possível visualizar os contatos entre as formações Irati e Corumbataí (Figura 5.13A).

A Formação Irati é composta por banco basal de rocha carbonática com cerca de 4 metros de espessura, recoberto pelo ritmito formado por pares de camadas de folhelhos cinza escuros intercaladas com rochas carbonáticas cinza claras. O ritmito (Figura 5.13B) possui cerca de 10 metros de espessura e é seccionado por veios verticais milimétricos. As camadas de folhelho exibem muitas concreções (Figura 5.13C) e veios horizontais de calcita fibrosa com espessuras da ordem de dois a cinco milímetros. As camadas de rochas carbonáticas possuem níveis contendo sílex preto e também apresentam concreções.

A Formação Corumbataí é constituída por pacote de siltitos com laminação heterolítica de coloração marrom a marrom avermelhada (Figura 5.13D), que possui 30 metros de espessura, recobertos por pacote de arenito fino maciço avermelhado, com 10 metros de 
espessura. Uma soleira de basalto com 5 a 10 metros de espessura e 50 a 100 metros de continuidade lateral, encontra-se no topo da sucessão.

A

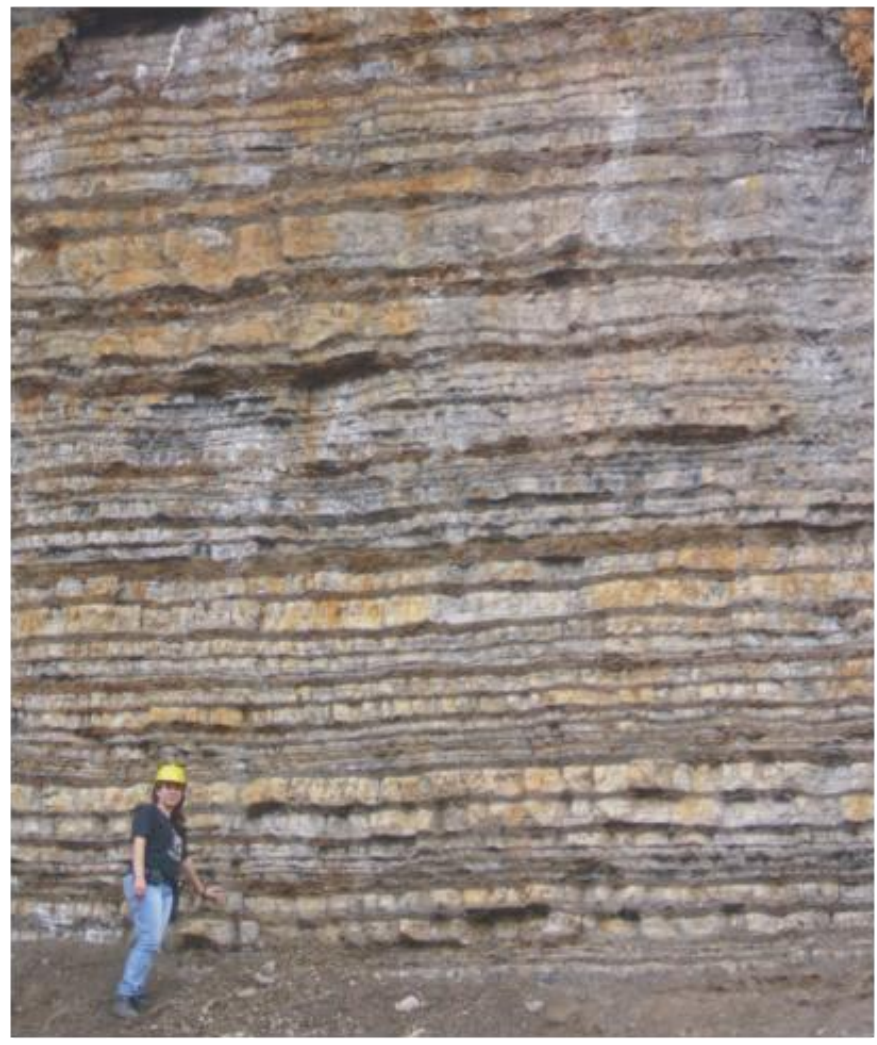

B

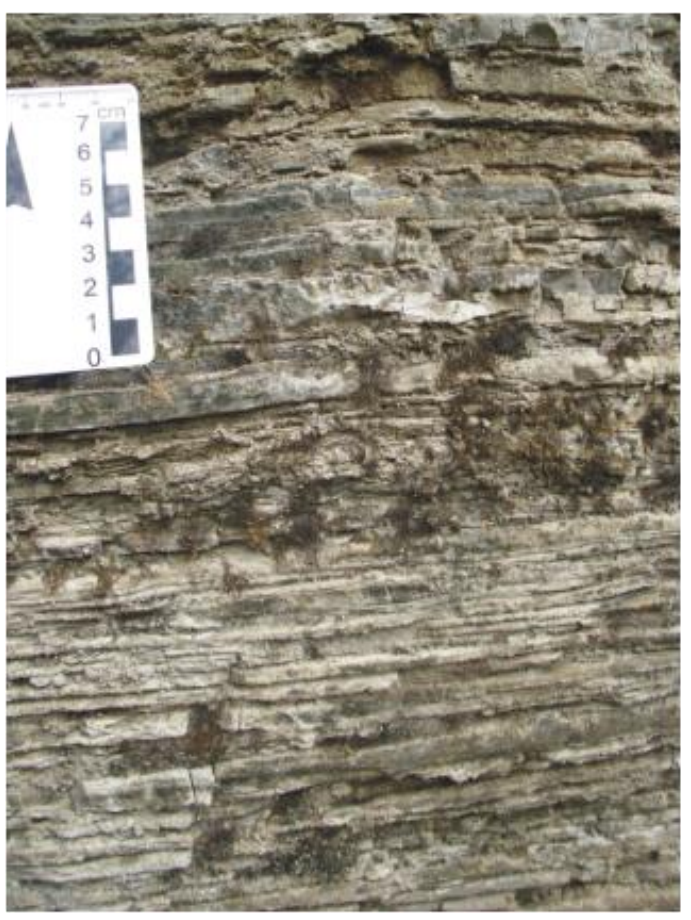

C

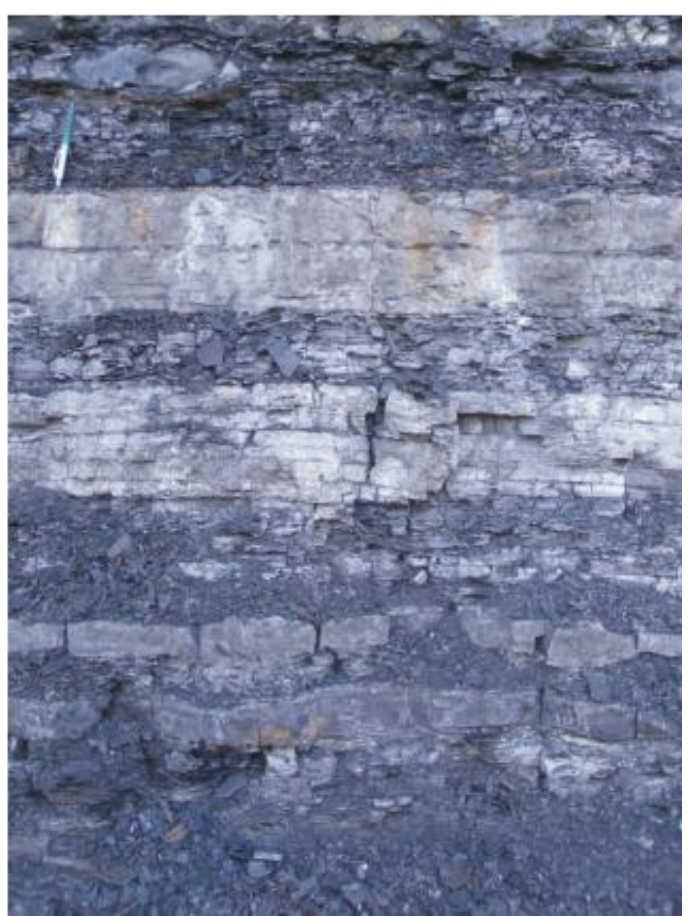

Figura 5.12: (A) Ritmito de rocha carbonática e folhelho. (B) Detalhe do banco de rocha carbonática (basal). (C) Detalhe do ritmito com intercalções de rochas carbonáticas e folhelhos. Mineração Vitti 2, distrito de Assistência, Rio Claro (SP). 


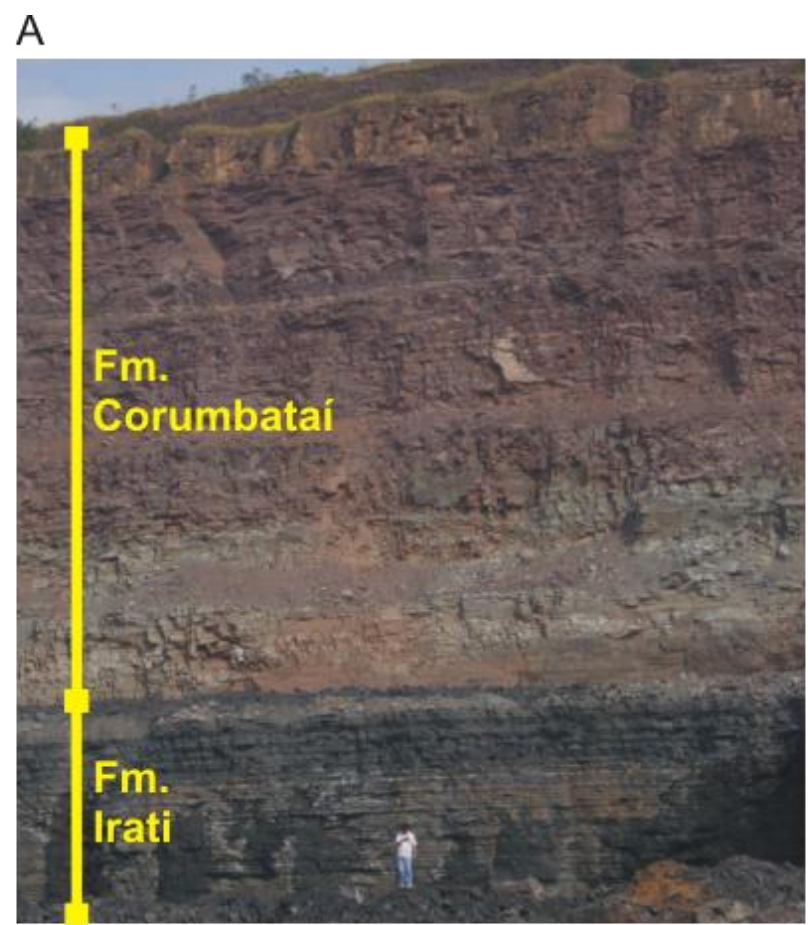

B

C
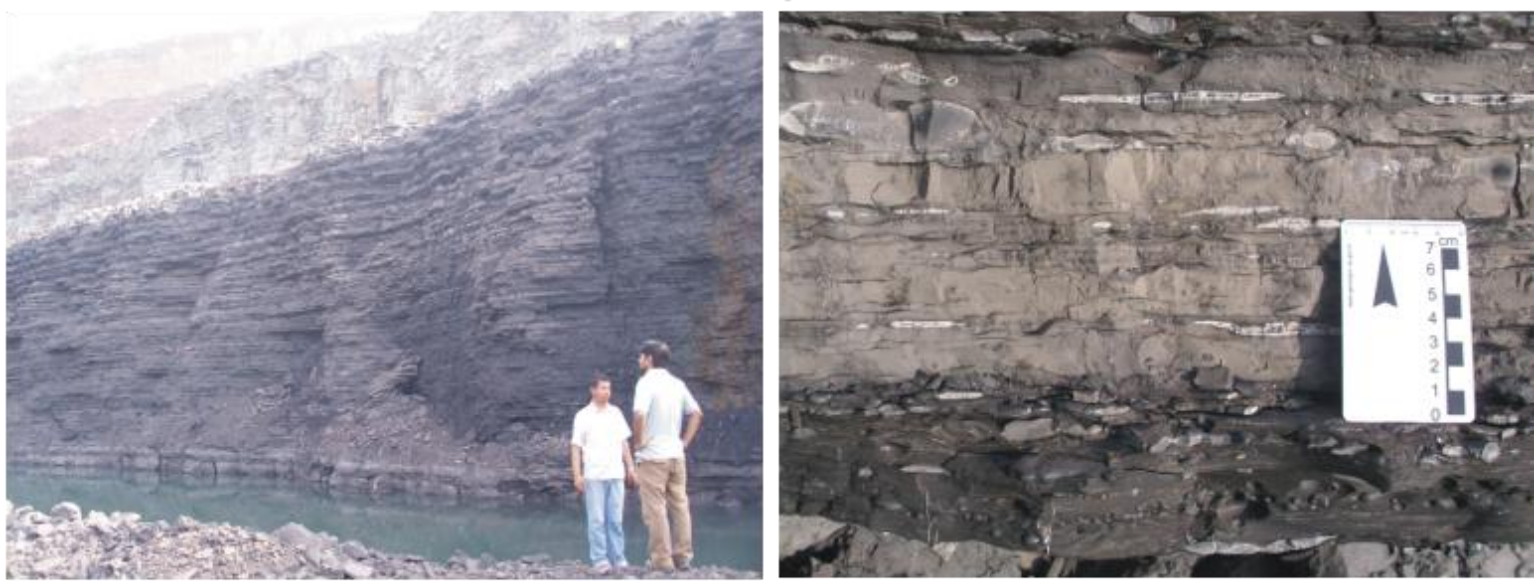

D

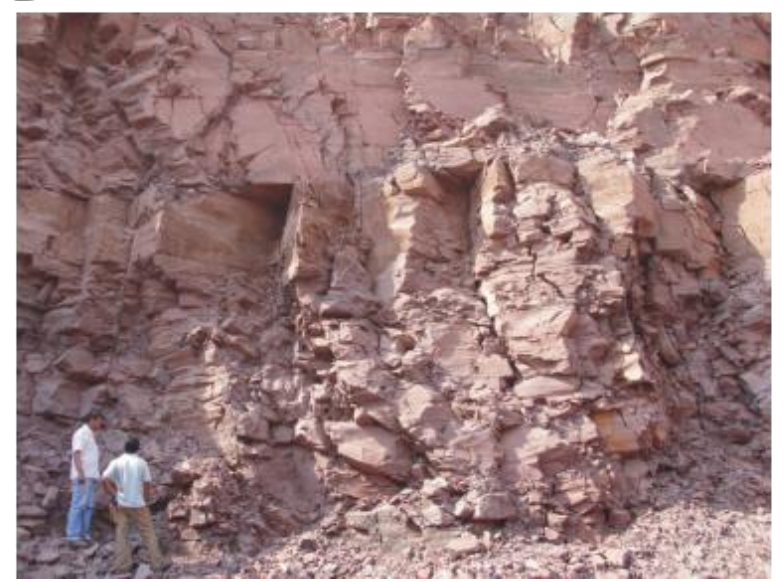

Figura 5.13: (A) Contato entre as formações Irati e Corumbataí. (B) Vista geral do afloramento da Formação. Irati, recoberto pela Formação Corumbataí. (C) Detalhe do ritmito de rochas carbonáticas e folhelhos. Nota-se a grande quantidade de concreções de sílex. (D) Vista geral do afloramento da Formação Corumbataí. Mineração Calcário Cruzeiro, Limeira (SP). 


\subsubsection{Afloramentos da Formação Serra Alta (Pontos 10 e 11)}

Os pontos 10 e 11 correspondem a afloramentos da Formação Serra Alta localizados, respectivamente, nos quilômetros 160 e 162 da Rodovia Castelo Branco (SP-280). Por se tratarem de afloramentos próximos e com características semelhantes, serão descritos conjuntamente.

A litologia predominante é siltito pastilhado de coloração cinza a castanho com laminação heterolítica (argila e silte). Há níveis milimétricos cimentados e presença de fraturas verticais retilíneas, sugerindo tratar-se de fraturas pós-compactação, preenchidas por calcita espática (cristais milimétricos). Observa-se ainda a ocorrência de diques clásticos de espessura centimétrica a decimétrica (Figura 5.14). As fraturas apresentam direções NE-SW e NW-SE.

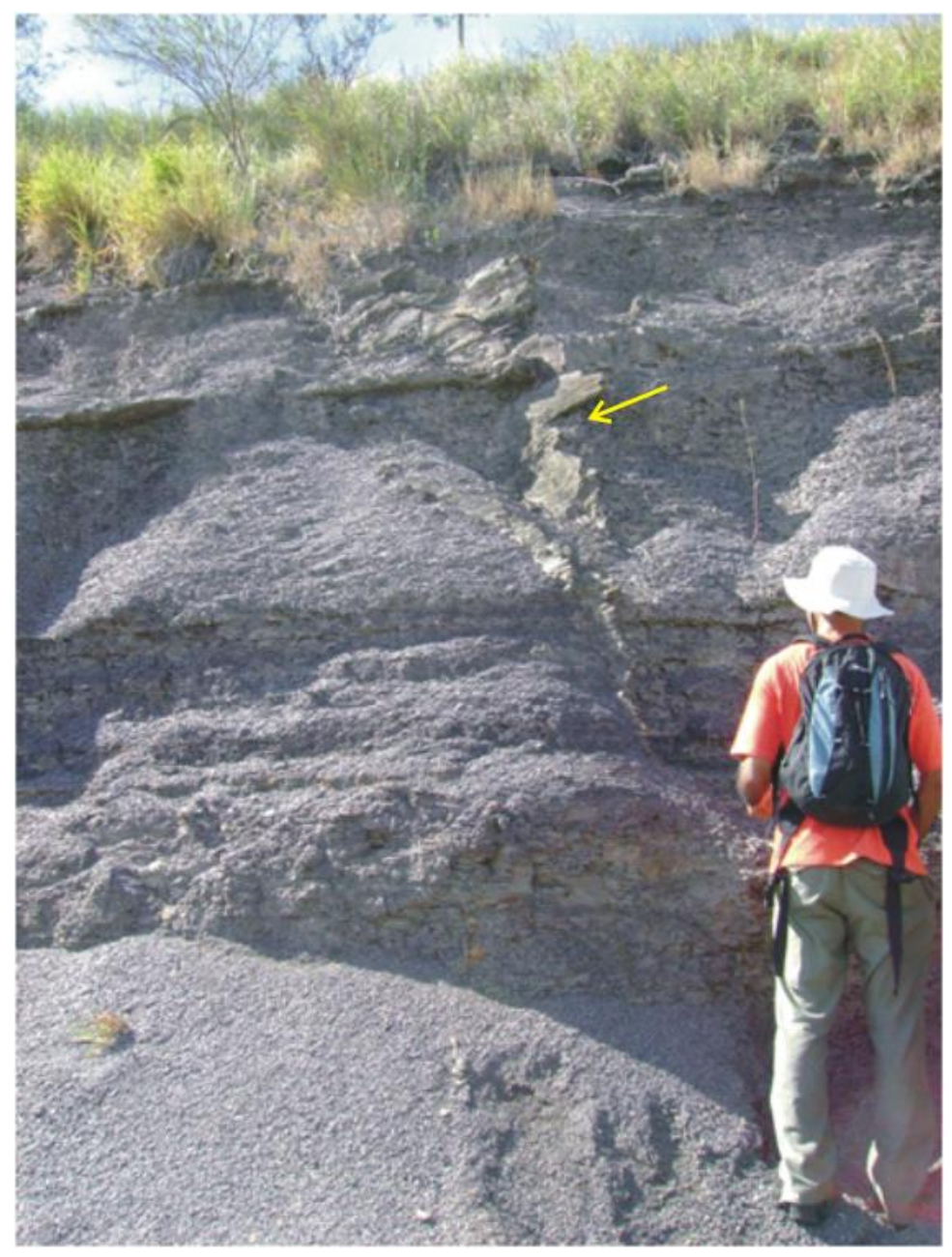

Figura 5.14: Vista de Geral de afloramento da Formação Serra Alta situado na Rodovia Presidente Castello Branco (SP). Nota-se a presença de dique clástico. 


\subsubsection{Afloramento Irati (Ponto 12)}

O afloramento consiste em pequena exposição (cerca de um metro) em terreno localizado no cruzamento das ruas Vicente Machado e Coronel Pires, no município de Irati, no Estado do Paraná. Nessa localidade, a Formação Irati corresponde a folhelho pastilhado, por vezes papiráceo, de coloração cinza escuro. O afloramento encontra-se encoberto por vegetação impossibilitando a descrição mais detalhada.

\subsubsection{Afloramento Engenheiro Gutierrez (Ponto 13)}

Afloramento situado ao lado da antiga estação de trem do distrito Engenheiro Gutierrez, no município de Irati, Estado do Paraná. Esse afloramento é próximo da localidade onde foi descrita a seção-tipo da Formação Irati, por White em 1908.

O afloramento apresenta cerca de dois metros de espessura e é composto por folhelhos pretos pastilhados. Devido ao fato da vegetação recobrir boa parte da seção, maiores observações foram prejudicadas.

\subsubsection{Afloramento São Mateus do Sul (Ponto 14)}

O afloramento consiste em um corte de estrada na BR-476, localizado três quilômetros a sul do município de São Mateus do Sul, no Estado do Paraná. A exposição tem aproximadamente 8 metros de espessura por dezenas de metros de extensão (Figura 5.15A).

A porção basal do afloramento é composta por banco de rocha carbonática cinza clara laminada, intercalada com folhelho de cor cinza (Figura 5.15C) com espessura de aproximadamente um metro e meio, o qual é recoberto por espesso pacote (cerca de três metros) de folhelhos cinza escuros (Figura 5.15B). A porção superior do afloramento é constituída por ritmito de rochas carbonáticas maciças (predominantes) e folhelhos cinza escuros (Figura 5.15D).

Fraturas milimétricas com duas direções principais NE-SW e NW-SE, que exibem espaçamento centimétrico a métrico, possuem continuidade vertical centimétrica a métrica. 


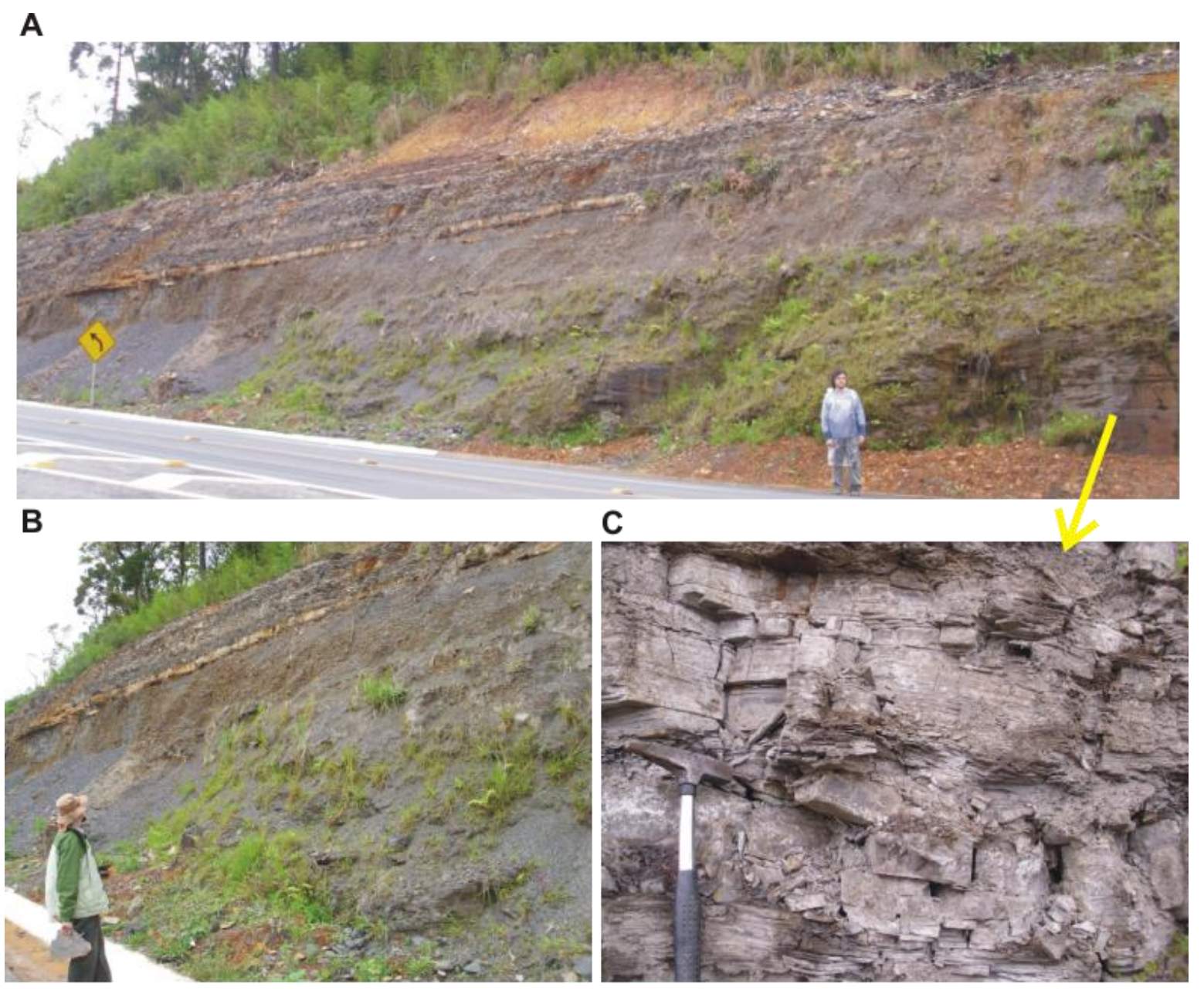

D

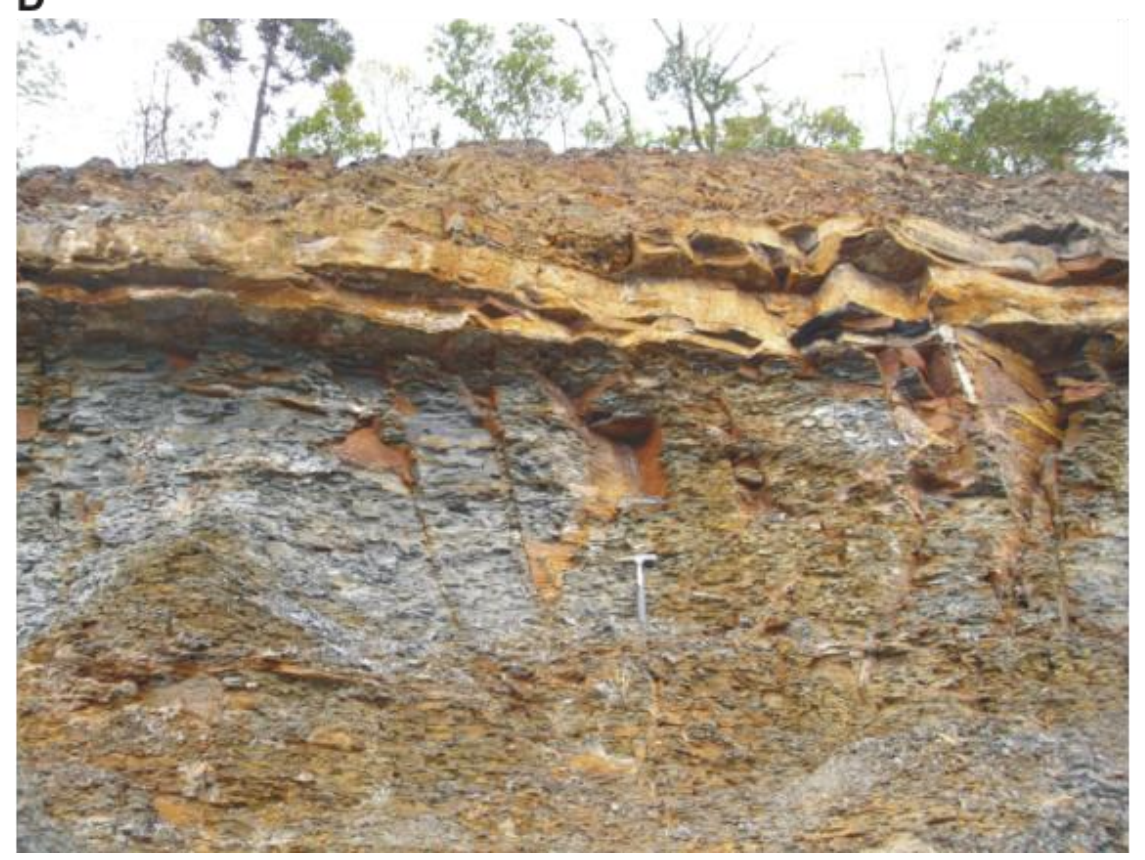

Figura 5.15: (A) Vista geral do afloramento. A seta indica a localização no afloramento do banco de rocha carbonática intercalado com níveis de folhelhos. (B) Pacote de folhelhos. (C) Detalhe da intercalação de rochas carbonáticas e folhelhos. (D) Pacote de folhelhos recoberto com ritmito de rochas carbonáticas e folhelhos. Afloramento na BR-476 próximo a São Mateus do Sul (PR). 


\subsection{Petrografia das seções delgadas}

A petrografia de seções delgadas possibilitou a descrição das rochas hospedeiras dos veios de calcita e quartzo cujas inclusões fluidas foram analisadas.

As rochas carbonáticas presentes no ponto 1 foram classificadas como mudstone com veio discordante de calcita espática e presença de betume entre o veio e o micrito. As faces da calcita sugerem contato fluido com o betume (Figura 5.16A). Os veios frequentemente apresentam calcita na forma microesparítica bordejando calcita espática (Figura 5.16B); eventualmente pode tratar-se de duas gerações de calcita. Neste caso, a calcita espática, que hospeda inclusões fluidas pertencentes ao Grupo I, estaria relacionada à segunda geração.

As rochas carbonáticas do ponto 2 (onde foram estudados os grupos II e III) foram classificadas como um mudstone formado pela alternância entre níveis de micrito e microesparito (Figura 5.16C), similar à textura fenestral. Uma das seções delgadas apresenta cristais de calcita com geminação, extinção ondulante e contatos suturados (Figura 5.16D) isto sugere deformação sob condição de soterramento (Ferrill et al 2004).

A duas seções delgadas descritas para o ponto 3 exibem geodos de quartzo e calcita deformados (Figura 5.16E e 5.16F). Os cristais de quartzo e calcita dos geodos são texturalmente semelhantes aos dos veios que hospedam as inclusões fluidas estudadas nos pontos 1 e 2. Através das relações entre os cristais de quartzo e de calcita dos geodos, interpreta-se que a cristalização do quartzo possa ser mais precoce que a da calcita. Sendo assim, no ponto 2 o preenchimento das fraturas por veios de quartzo pode ser anterior ao preenchimento pelos veios de calcita. Outra possível evidência para essa interpretação é o fato de que na atividade de campo foi observado um veio de quartzo aparentemente truncado por veio de calcita.

Seções delgadas descritas para rochas carbonáticas dos pontos 6, 8 e 9 apresentam pequenas variações na sua classificação. No ponto 6 , as rochas carbonáticas correspondem a um mudstone microespático homogêneo, sem laminação, com presença de veio de calcita espática (Figura 5.17A). As seções delgadas descritas para o ponto 8 permitiram reconhecer um mudstone micrítico com laminação irregular contendo matéria orgânica e porosidade fenestral preenchida por microesparito (Figura 5.17B) e um packstone com pelóides e bioclastos (5.17C). No ponto 9 , a rocha carbonática corresponde a um mudstone (Figura 5.17D). 
A

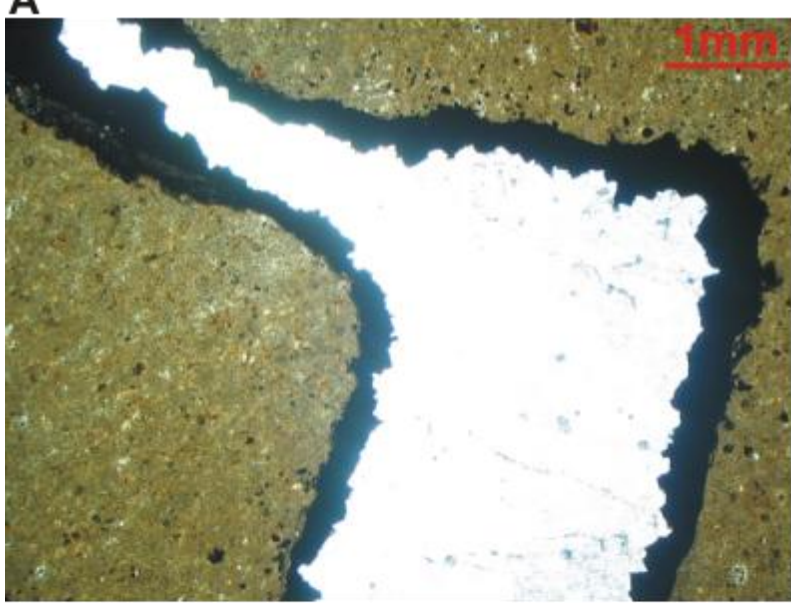

C

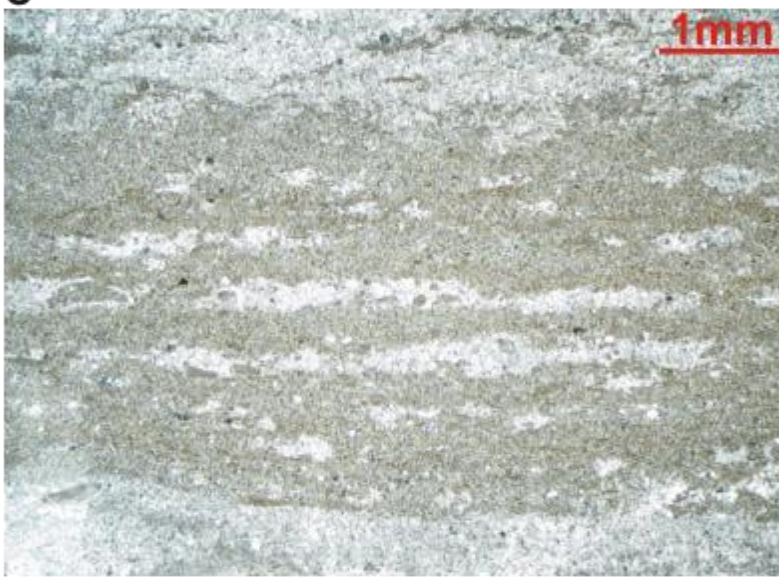

B

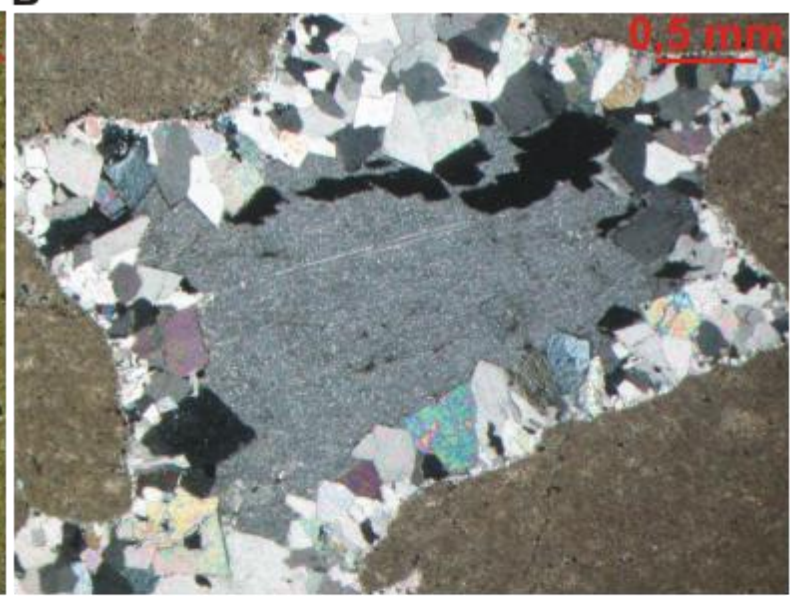

D

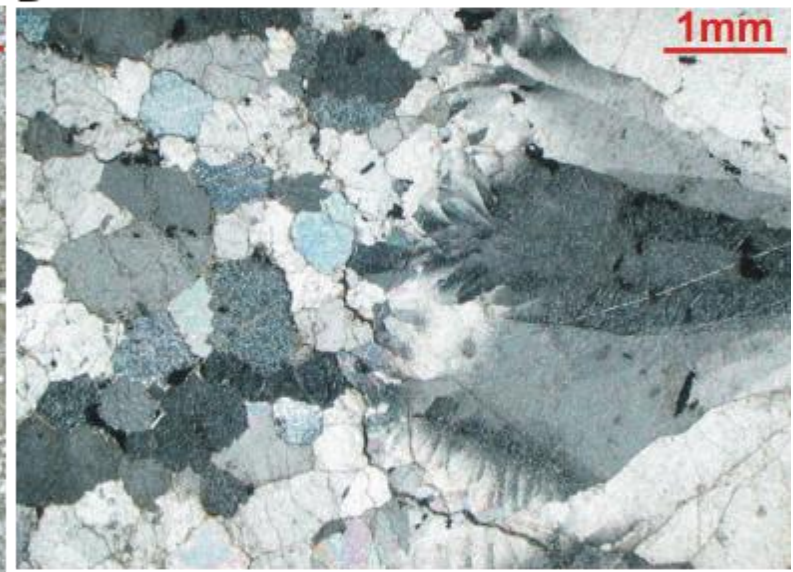

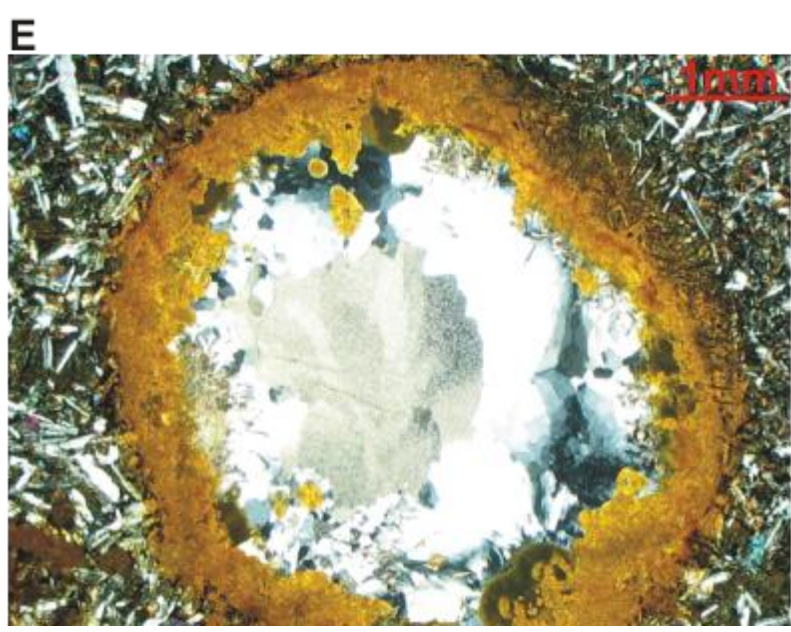

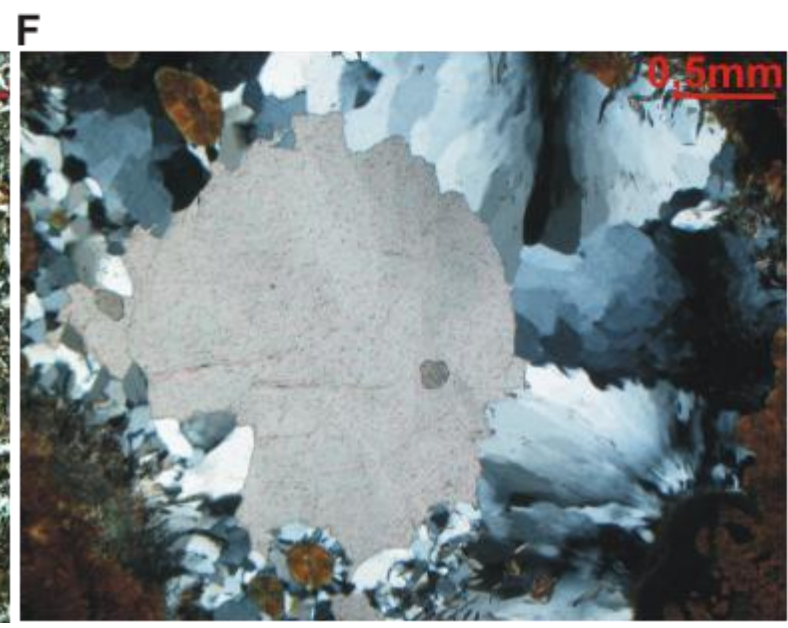

Figura 5.16: (A) Mudstone com veio discordante de calcita espática e presença de betume. As faces da calcita sugerem contato fluido com o betume. (B) Veios de calcita microesparítica bordejando calcita espática; eventualmente pode tratar-se de duas gerações de calcita. (C) Mudstone formado pela alternância entre níveis de micrito e microesparito, similar à textura fenestral. (D) Cristais de calcita com geminação, extinção ondulante e contatos suturados. (E) Geodo de quartzo e calcita deformados e (F) Detalhe do geodo de quartzo e calcita deformados. 
A

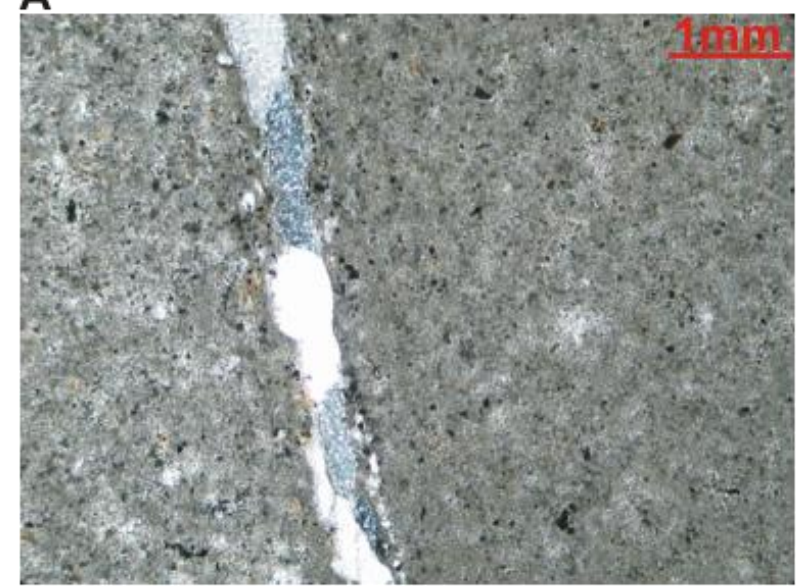

C

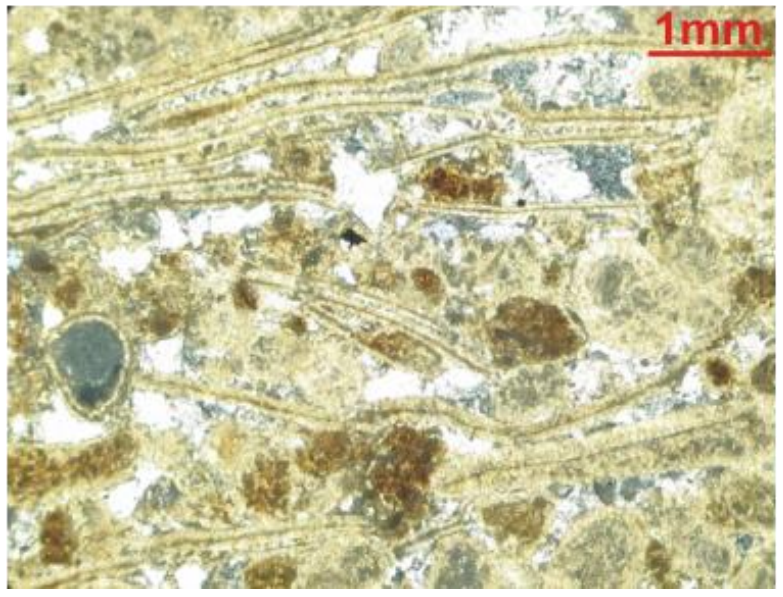

B

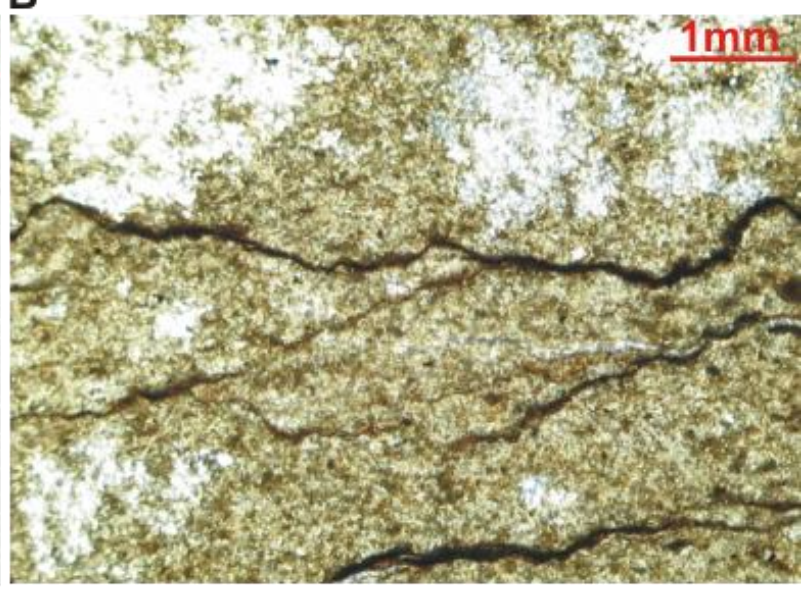

D

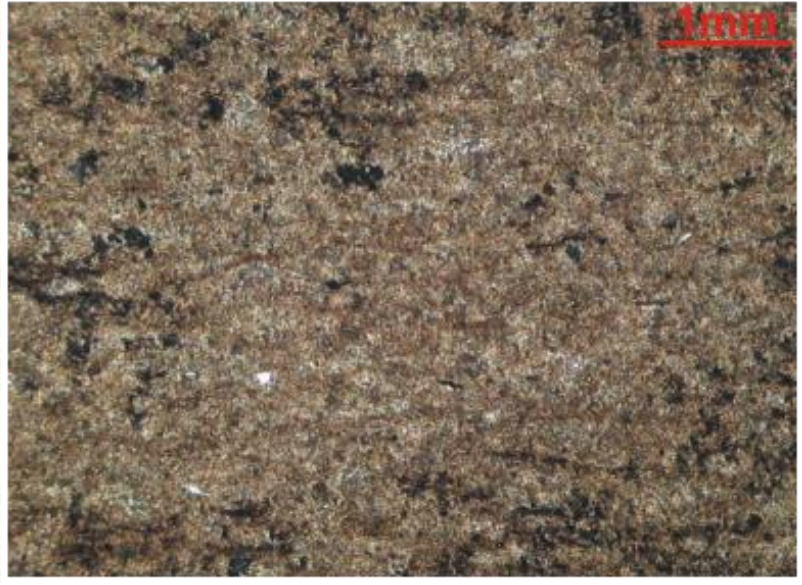

Figura 5.17: (A) Mudstone microespático homogêneo, sem laminação, com presença de veio de calcita espática. (B) Mudstone micrítico com laminação irregular contendo matéria orgânica e porosidade fenestral preenchida por microesparito. (C) Packstone com pelóides e bioclastos. (D) Mudstone. 


\subsection{Análises de Carbono Orgânico Total (COT) e enxofre (S)}

A Tabela 5.1 e a Figura 5.18 apresentam os resultados das análises de carbono orgânico total e enxofre dos folhelhos das formações Irati e Corumbataí e siltitos da Formação Serra Alta.

As amostras de folhelho da Formação Irati coletadas no Estado de São Paulo apresentam teores de carbono orgânico total entre 0,43 e 7,1\%, com média de 2,46\%, enquanto, os teores de enxofre variaram desde inferiores a 0,1 a até $2,35 \%$, com média de 0,99\%. Por sua vez, os folhelhos da Formação Irati no Estado do Paraná exibiram teores de carbono orgânico entre 7,83 e 17,41\%, com média de $11,32 \%$ e teores de enxofre entre 0,79 e $6,04 \%$, com média de $2,74 \%$.

A Figura 5.19 apresenta um gráfico de correlação entre o teor de enxofre e a concentração de carbono orgânico total para as amostras pertencentes às seções dos pontos 7 e 8.

As figuras 5.20 e 5.21 apresentam a distribuição estratigráfica da coleta de amostras de folhelhos da Formação Irati efetuada nos pontos 7 e 8 (ver seção 2.2) e suas respectivas concentrações de carbono orgânico total. Estas se situaram entre 1,51 e 3,03\% (ponto 8) e 1,52 e 2,98\%, (ponto 9), com predomínio de concentrações ao redor de $2 \%$ em ambos os afloramentos.

As amostras das formações Serra Alta e Corumbataí possuem teores de carbono orgânico total muito semelhantes, 0,22 e 0,31\% para a Formação Serra Alta e 0,19\% para a Formação Corumbataí. Os teores de enxofre encontrados para a Formação Serra Alta foram de 0,017 e 0,022\%, e de 0,03\% para a Formação Corumbataí. 
Tabela 5.1 - Resultados de Carbono Orgânico Total (COT) de amostras das formações Irati, Corumbataí e Serra Alta.

\begin{tabular}{|c|c|c|c|c|}
\hline Ponto & Unidade & Amostra & COT (\%) & S (\%) \\
\hline 2 & Fm.Irati & IP-41 & 1,77 & $<0,10$ \\
\hline 3 & Fm.Irati & IP-40 & 0,43 & $<0,10$ \\
\hline 5 & Fm. Corumbataí & IP-29 & 0,19 & 0,03 \\
\hline 6 & Fm.Irati & IP-30 & 6,15 & 2,22 \\
\hline 7 & Fm.Irati & IP-31 & 7,1 & 2,35 \\
\hline 8 & Fm.Irati & IP-42-F1 & 2,61 & 2,12 \\
\hline 8 & Fm.Irati & IP-42-F2 & 2,61 & 0,93 \\
\hline 8 & Fm.Irati & IP-42-F3 & 2,24 & 1,7 \\
\hline 8 & Fm.Irati & IP-42-F4 & 1,93 & 0,93 \\
\hline 8 & Fm.Irati & IP-42-F5 & 2,32 & 1,11 \\
\hline 8 & Fm.Irati & IP-42-F6 & 2,63 & 1,49 \\
\hline 8 & Fm.Irati & IP-42-F7 & 2,13 & 1,92 \\
\hline 8 & Fm.Irati & IP-42- F8 & 2,31 & 2,21 \\
\hline 8 & Fm.Irati & IP-42- F9 & 2,31 & 1,85 \\
\hline 8 & Fm.Irati & IP-42- F10 & 2,11 & 1,93 \\
\hline 8 & Fm.Irati & IP-42-F11 & 2,86 & 1,79 \\
\hline 8 & Fm.Irati & IP-42-F12 & 3,03 & 1,74 \\
\hline 8 & Fm.Irati & IP-42-F13 & 2,09 & 0,23 \\
\hline 8 & Fm.Irati & IP-42-F14 & 1,51 & 0,11 \\
\hline 8 & Fm.Irati & IP-42-F15 & 1,94 & 0,12 \\
\hline 8 & Fm.Irati & IP-42-F16 & 2,79 & 0,12 \\
\hline 8 & Fm.Irati & IP-42-F17 & 1,78 & 0,16 \\
\hline 9 & Fm.Irati & IP-44-F5 & 1,52 & 0,34 \\
\hline 9 & Fm.Irati & IP-44-F6 & 2,15 & 0,21 \\
\hline 9 & Fm.Irati & IP-44-F7 & 2,03 & 0,55 \\
\hline 9 & Fm.Irati & IP-44- F8 & 2,31 & 0,21 \\
\hline 9 & Fm.Irati & IP-44- F9 & 2,31 & 0,69 \\
\hline 9 & Fm.Irati & IP-44- F10 & 2,11 & 0,34 \\
\hline 9 & Fm.Irati & IP-44-FA1 & 2,11 & 0,69 \\
\hline 9 & Fm.Irati & IP-44-FA2 & 2,08 & 0,57 \\
\hline 9 & Fm.Irati & IP-44-FA3 & 2,98 & 0,45 \\
\hline 9 & Fm.Irati & IP-44-FA4 & 2,04 & 0,57 \\
\hline 10 & Fm. Serra Alta & IP-01 & 0,31 & 0,019 \\
\hline 11 & Fm. Serra Alta & IP-02 & 0,22 & 0,017 \\
\hline 12 & Fm.Irati & PR-03 & 9,79 & 0,79 \\
\hline 13 & Fm.Irati & PR-04 & 7,83 & 1,62 \\
\hline 14 & Fm.Irati & PR-05-A & 10,27 & 6,04 \\
\hline 14 & Fm.Irati & PR-05-B & 17,41 & 2,53 \\
\hline
\end{tabular}




\section{Carbono Orgânico Total e Enxofre}

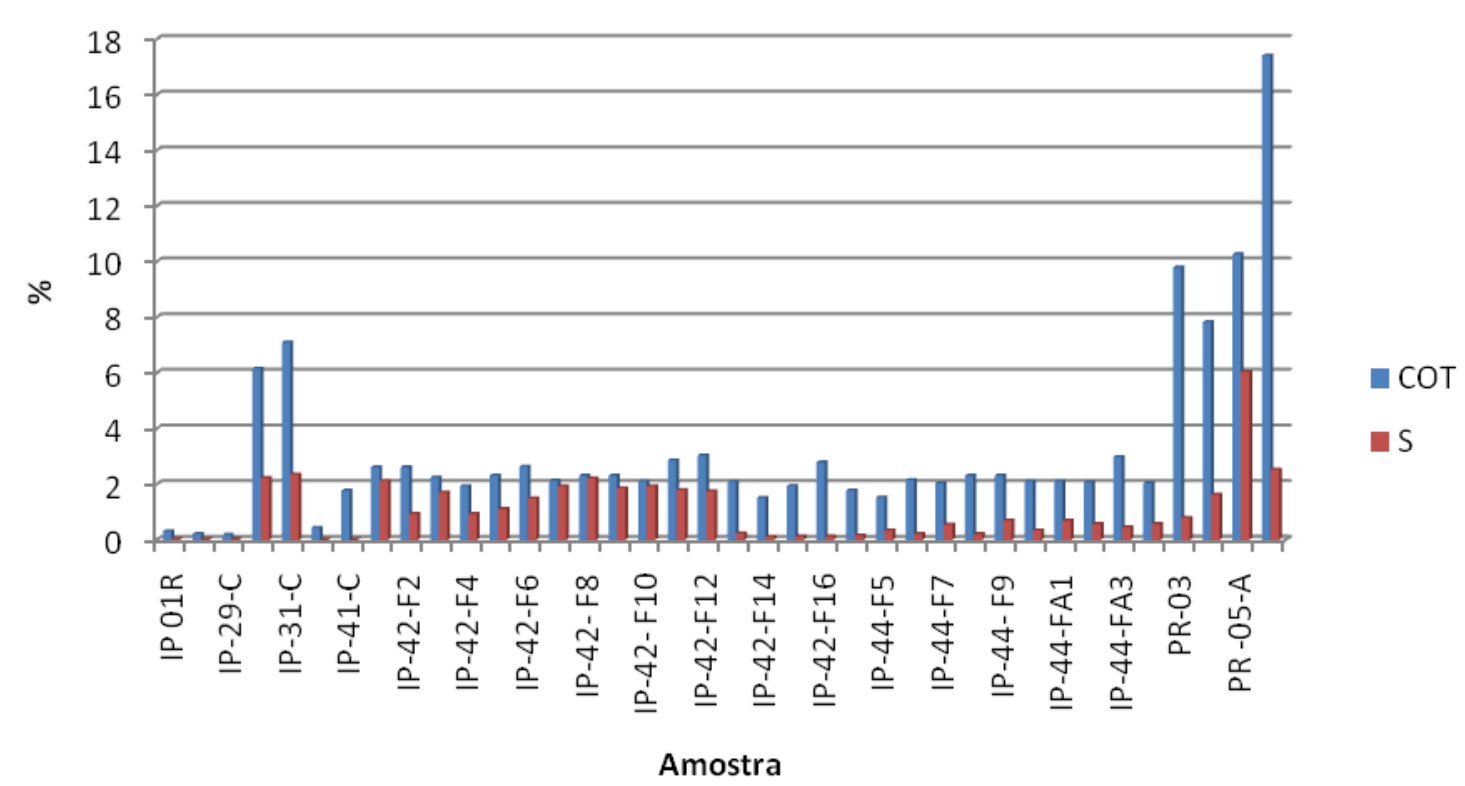

Figura 5.18: Gráfico de teor de carbono orgânico total (COT) e enxofre (S) de amostras coletadas nas formações Irati, Serra Alta e Corumbataí.

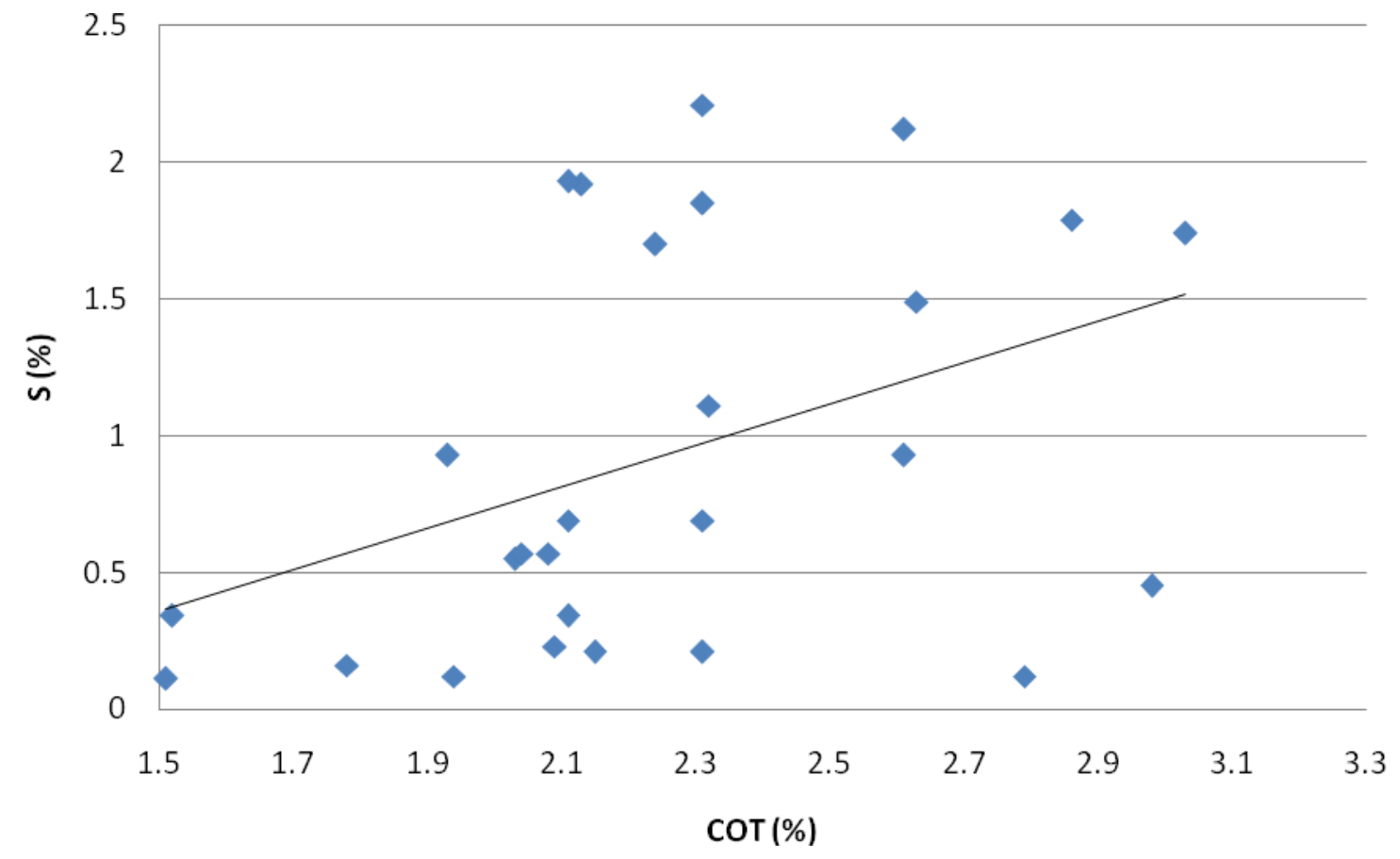

Figura 5.19: Gráfico de correlação entre teor de carbono orgânico total (COT) e enxofre (S) de folhelhos da Formação Irati para amostras coletadas nos pontos 8 e 9. 


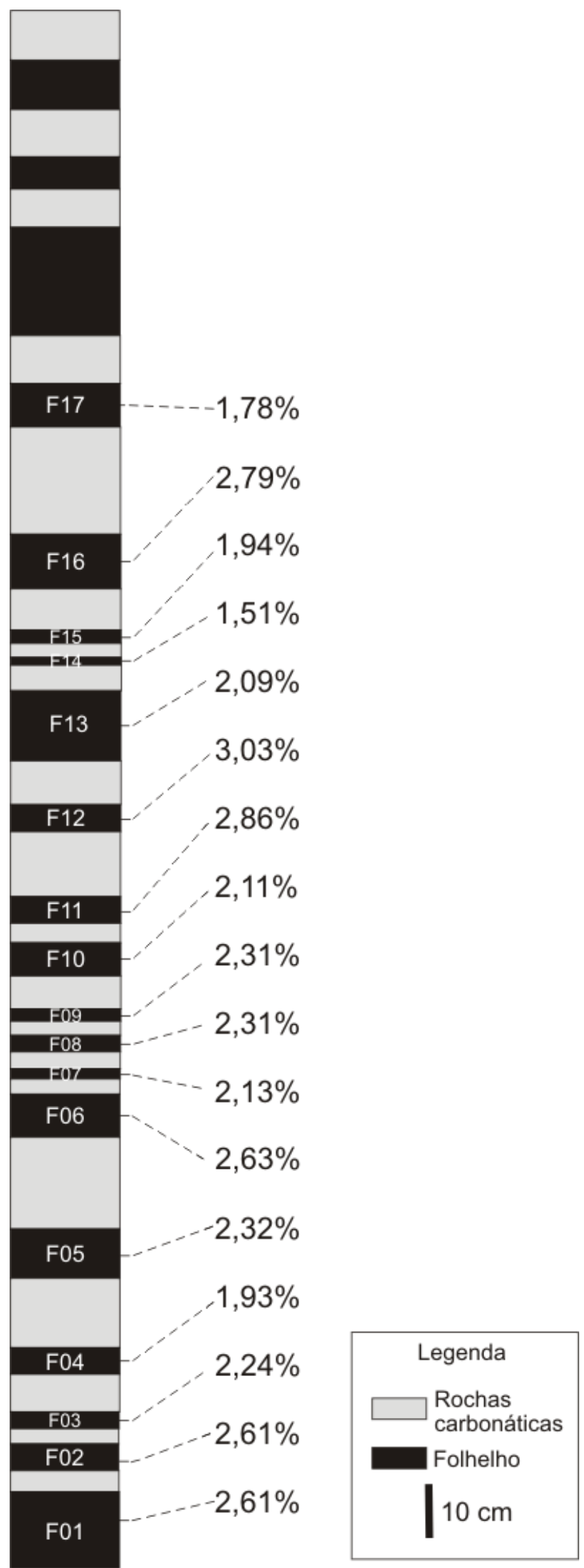

Figura 5.20: Distribuição estratigráfica das amostras coletadas no ponto 8 e seus resultados de carbono orgânico total (COT). 


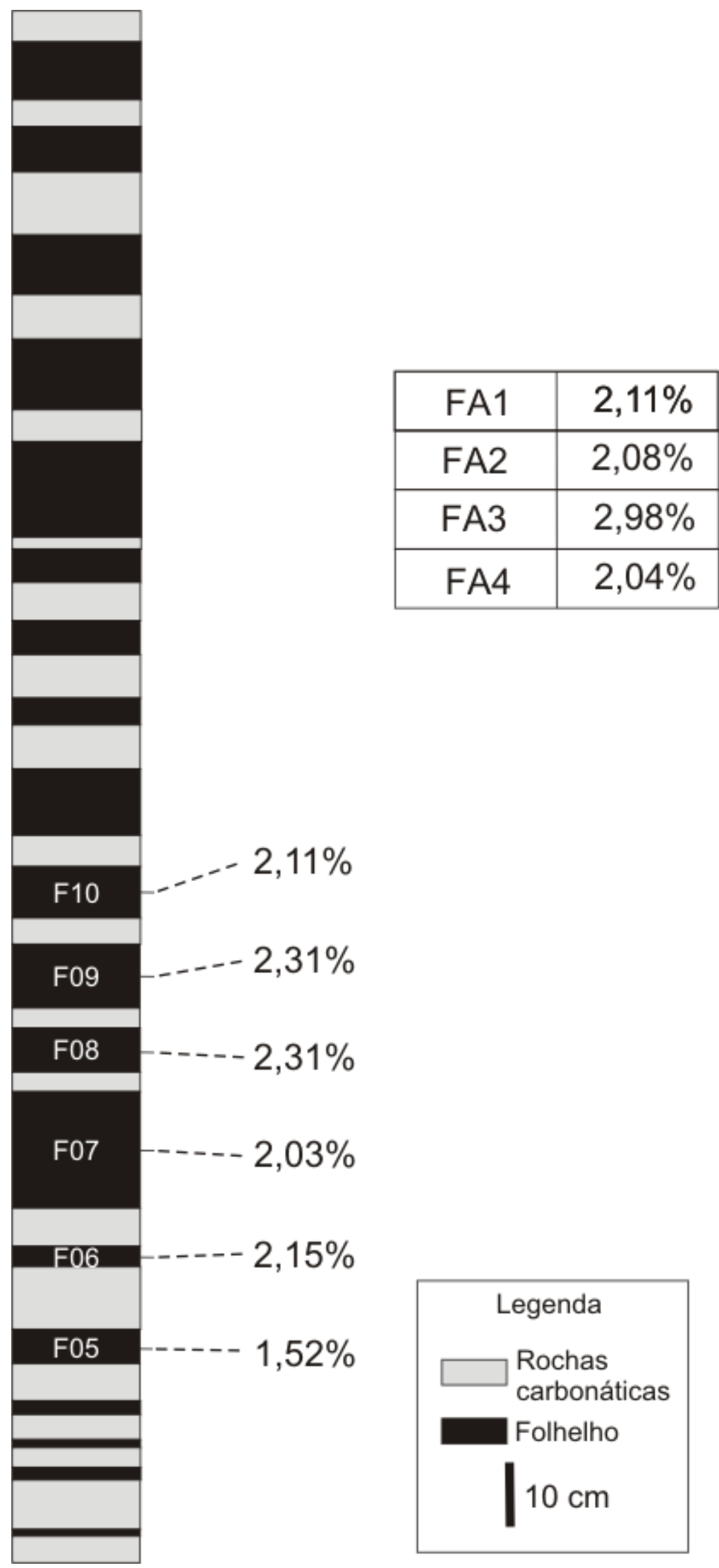

Figura 5.21: Distribuição estratigráfica das amostras coletadas no ponto 9 e seus resultados de carbono orgânico total (COT). O quadro acima contém os resultados de COT de amostras coletadas sem controle estratigráfico. 


\subsection{Estudo de Inclusões Fluidas}

\subsubsection{Microscopia Petrográfica}

\section{$\underline{\text { Grupo I }}$}

A petrografia das inclusões fluidas encontradas nos veios de calcita espática de amostras de Cesário Lange permitiu caracterizar um grupo de inclusões bifásicas associadas a inclusões monofásicas, com morfologia irregular (monofásicas principalmente) a regular. Estas inclusões muitas vezes constituem cristais negativos com dimensões entre $5 \mu \mathrm{m}$ e 15 $\mu \mathrm{m}$. Nas inclusões bifásicas, o volume da fase vapor geralmente não ultrapassa 5 a $10 \%$ do volume da inclusão.

Observa-se frequentemente inclusões orientadas na direção da clivagem dos cristais de calcita. É comum a ocorrência de cristais de carbonato límpidos desprovidos de inclusões, cristais com inclusões bifásicas ou monofásicas isoladas e cristais com concentrações de inclusões em trilhas internas ao cristal (Figura 5.22A).

Ocorrem ainda inclusões com feições de escape de fluidos. Também são observadas inclusões fluidas isoladas, compostas por hidrocarbonetos, com dimensões geralmente situadas entre $20 \mu \mathrm{m}$ e $50 \mu \mathrm{m}$, bolhas de coloração escura, e que apresentam fluorescência de cor amarelada e azul pálido quando observadas com luz ultravioleta (figuras 5.22B, 5.22C, $5.22 \mathrm{D}$ e $5.22 \mathrm{E})$.

\section{$\underline{\text { Grupo II }}$}

O estudo petrográfico das inclusões fluidas hospedadas nos veios de calcita espática das amostras situadas nas proximidades de Paraisolândia possibilitou caracterizar um grupo de inclusões fluidas bifásicas associadas a inclusões monofásicas, com formas geralmente irregulares.

Frequentemente, as inclusões possuem dimensões desde inferiores a $5 \mu \mathrm{m}$ a até $10 \mu \mathrm{m}$. Nas inclusões bifásicas, o volume da fase vapor é inferior a 5 a $10 \%$ do volume da inclusão. Com exceção dos campos C1 e C8, que apresentam trilhas de inclusões aparentemente pseudo-secudárias, todos os demais campos exibem dezenas de inclusões predominantemente bifásicas com monofásicas subordinadas, orientadas, formando grupos de trilhas de inclusões secundárias paralelas entre si, que seccionam os cristais de calcita (figuras 5.23 e 5.24). 
Mais raramente, são observadas inclusões compostas por hidrocarbonetos; estas exibem morfologia irregular, dimensões entre $10 \mu \mathrm{m}$ e $20 \mu \mathrm{m}$, pequenas bolhas de fase vapor e fluorescência de cor azul pálida, quando observadas com auxílio de luz UV (Figura 5.25).

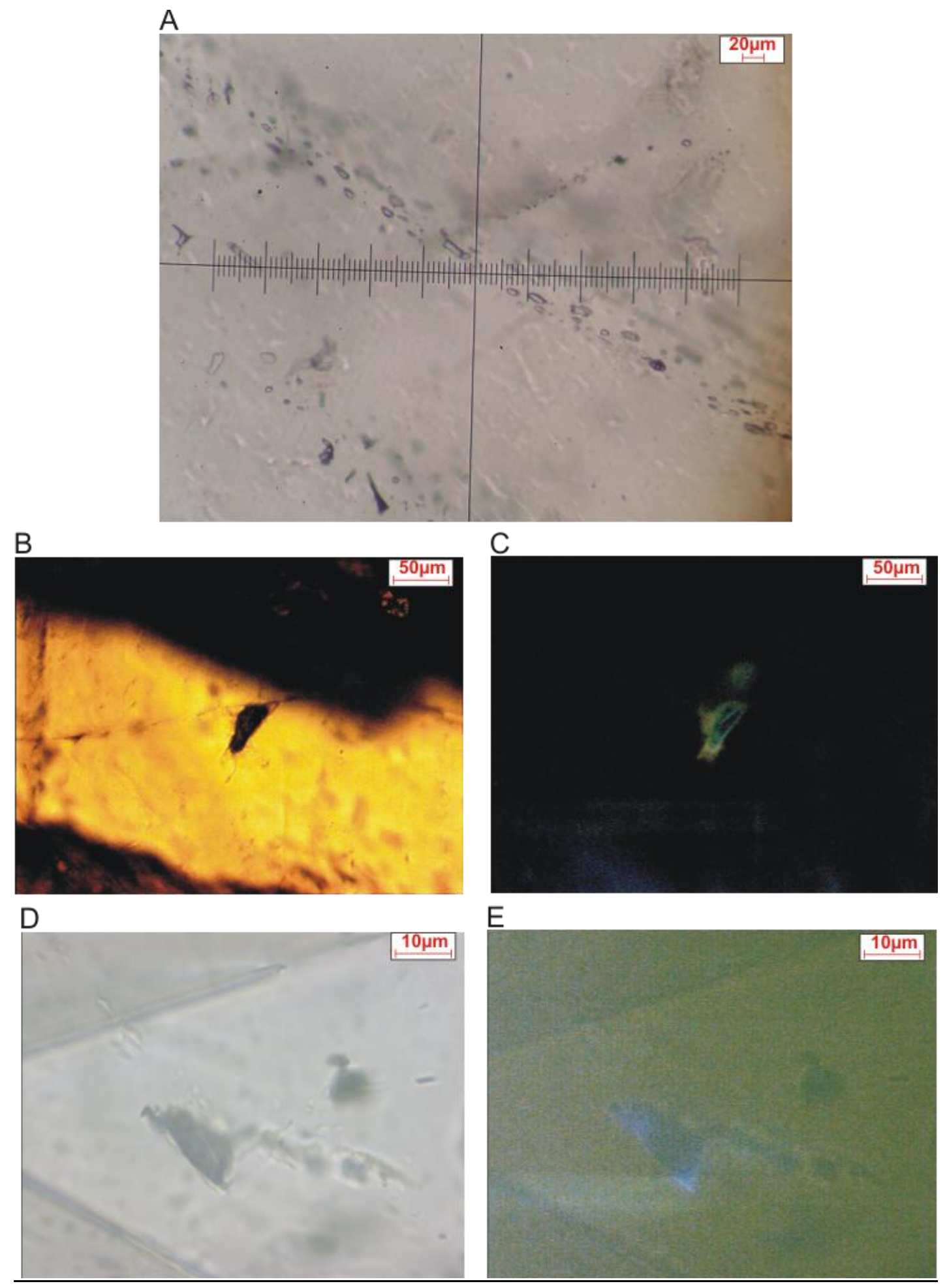

Figura 5.22: Fotomicrografias de inclusões fluidas pertencentes ao Grupo I. (A) Trilha de inclusões pseudo-secundárias; (B) e (D) Inclusões fluidas compostas por hidrocarbonetos observadas em microscópio petrográfico com luz transmitida, e com luz ultravioleta (C) e (E). Nota-se que as inclusões exibem fluorescência em tons amarelados e azuis pálidos. 

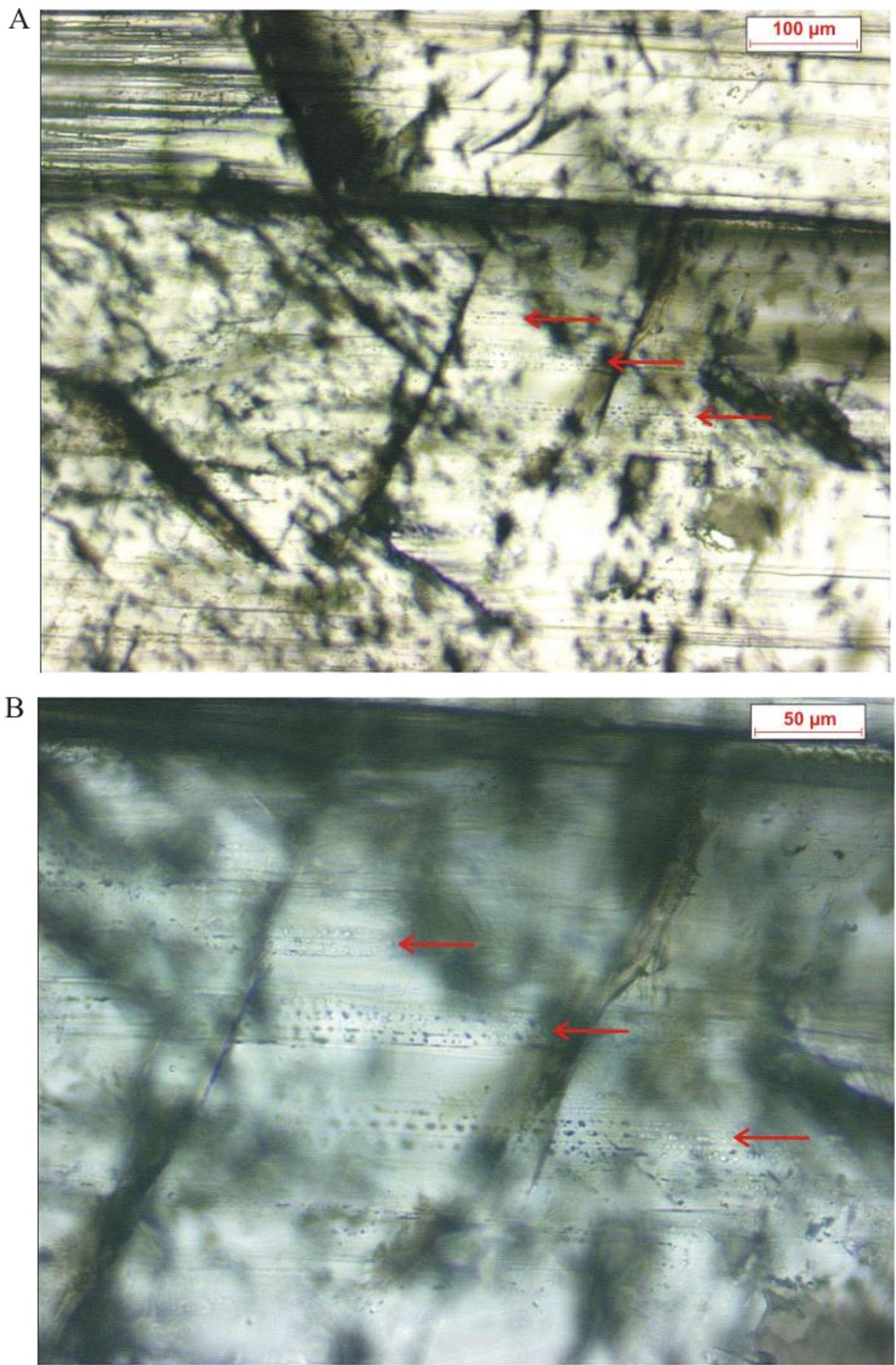

Figura 5.23: Fotomicrografias de inclusões fluidas pertencentes ao Grupo II. (A) Grupos de trilhas de inclusões fluidas secundárias que seccionam os cristais de calcita espática. (B) Detalhe da fotomicrografia anterior. 

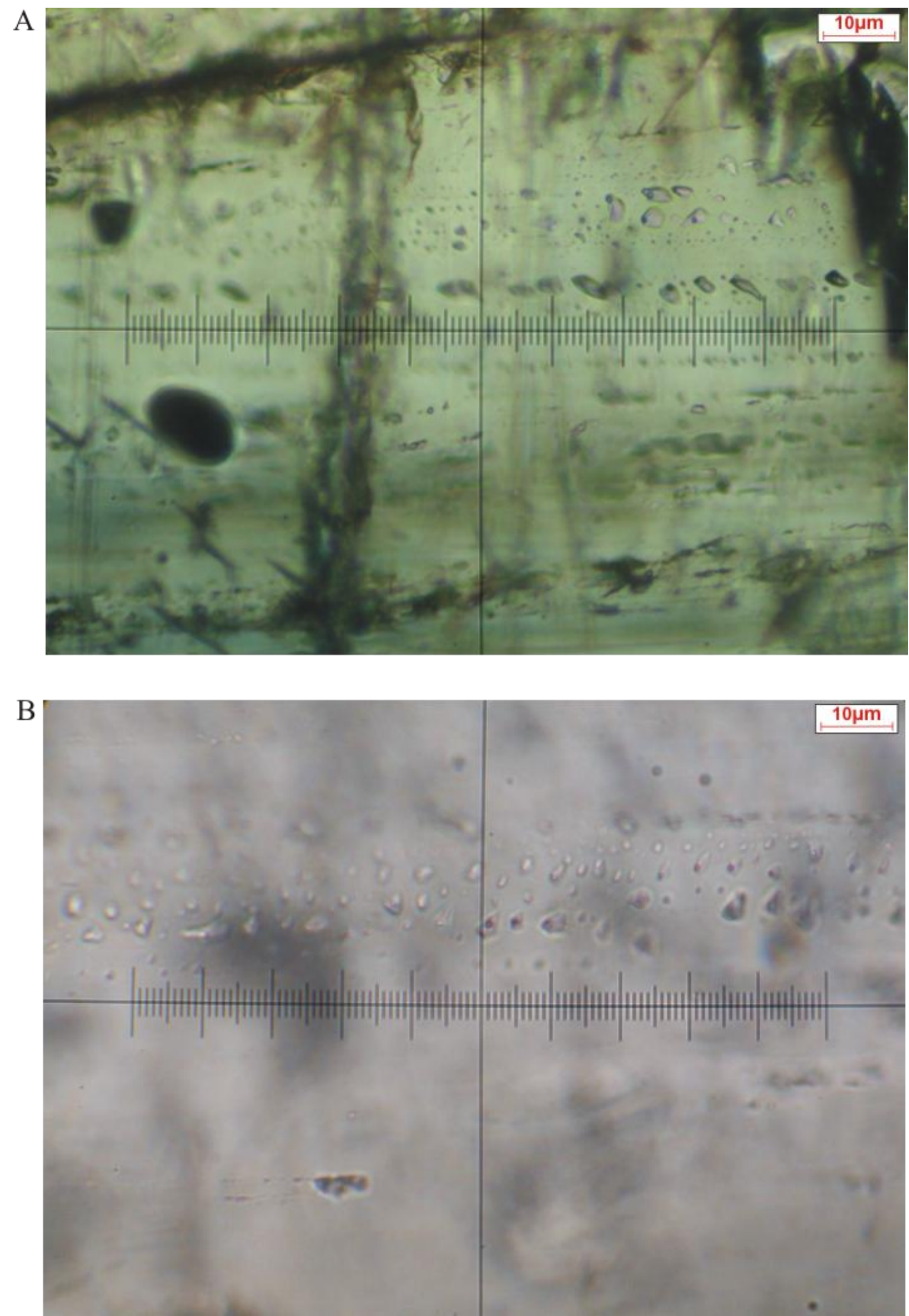

Figura 5.24: Fotomicrografias de inclusões fluidas pertencentes ao Grupo II. (A) Trilha de inclusões fluidas bifásicas e monofásicas secundárias (campo C4). (B) Trilha de inclusões fluidas bifásicas e monofásicas secundárias (campo C6). 


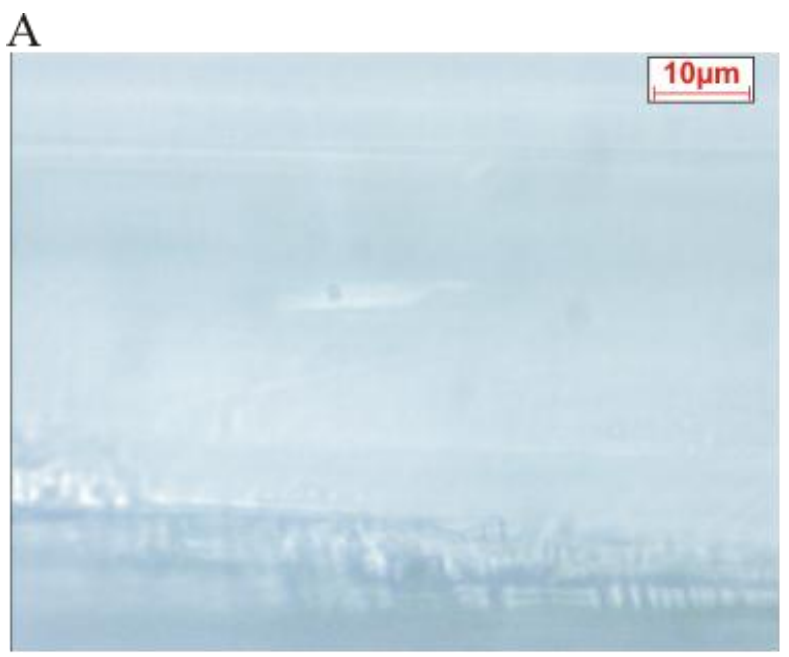

$\mathrm{B}$

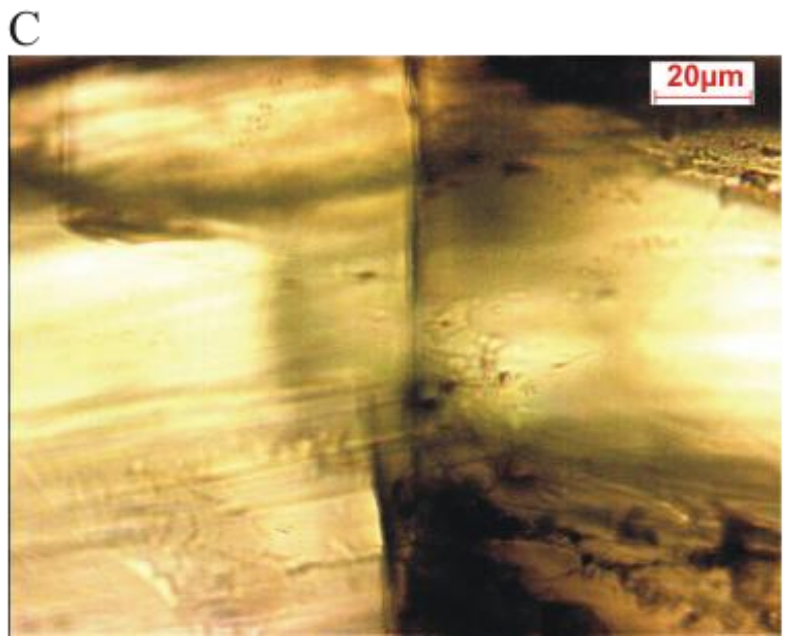

$\mathrm{D}$

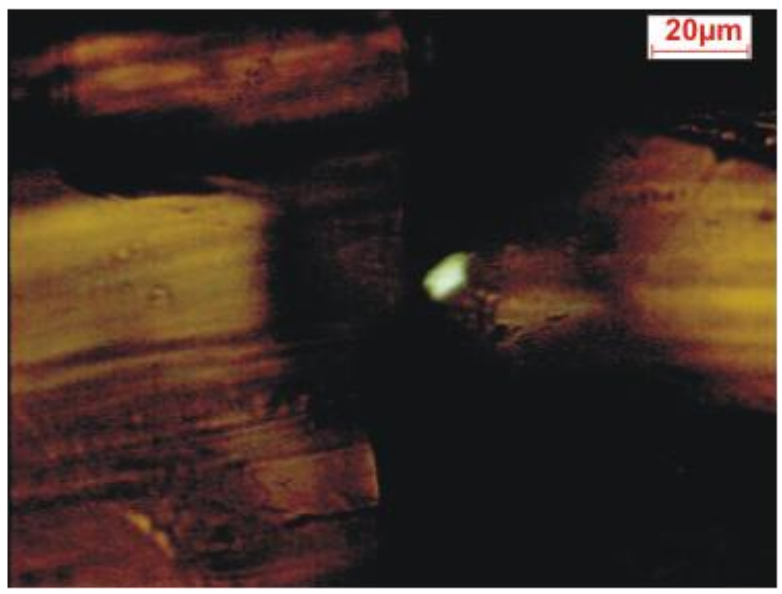

Figura 5.25: Fotomicrografias de inclusões fluidas pertencentes ao Grupo II. (A) e (C) Inclusões fluidas compostas por hidrocarbonetos observadas em microscópio petrográfico com luz transmitida, e com luz ultravioleta (C) e (E). Nota-se que as inclusões exibem fluorescência em tom azul pálido. 


\section{Grupo III}

A petrografia das inclusões fluidas encontradas nos veios de quartzo das proximidades de Paraisolândia permitiu caracterizar um grupo de inclusões bifásicas associadas a monofásicas, com morfologia irregular (monofásicas principalmente) a regular. Estas inclusões muitas vezes constituem cristais negativos com dimensões entre $5 \mu \mathrm{m}$ e $25 \mu \mathrm{m}$.

Observa-se frequentemente inclusões isoladas, sem orientação preferencial aparente, inclusões pseudo-secundárias distribuídas em trilhas internas ao cristal (Figura 5.26 e figuras 5.27A e 5.27B) e trilhas de inclusões situadas nas bordas dos cristais, possivelmente secundárias. Nas inclusões bifásicas, o volume da fase vapor geralmente não ultrapassa 10 a $15 \%$ do volume da inclusão.

Algumas inclusões (Figura 41C) diferenciam-se das demais por apresentarem grandes dimensões (até $100 \mu \mathrm{m}$ ) e por exibirem aspecto escurecido, sugerindo tratarem-se de inclusões de hidrocarbonetos. Contudo, quando observadas com auxilio de luz ultravioleta, não apresentaram fluorescentes.

Foram encontradas evidências de modificações posteriores tais como estrangulamento (necking down) e feições de escape de fluidos (figuras 5.27D e 5.27E).

Destaca-se a presença de inclusões fluidas compostas por hidrocarbonetos. Estas inclusões apresentam, dimensões entre $20 \mu \mathrm{m}$ e $50 \mu \mathrm{m}$, morfologia irregular (predominante) a regular, relações variáveis entre as fases líquido-vapor (inclusões com fase vapor ocupando aproximadamente 60 a $70 \%$ do volume da inclusão são as predominantes), bolhas escurecidas, e cores de fluorescência variando entre azul pálida a esbranquiçada, quando observadas sob luz UV (figuras 5.28 e 5.29). 


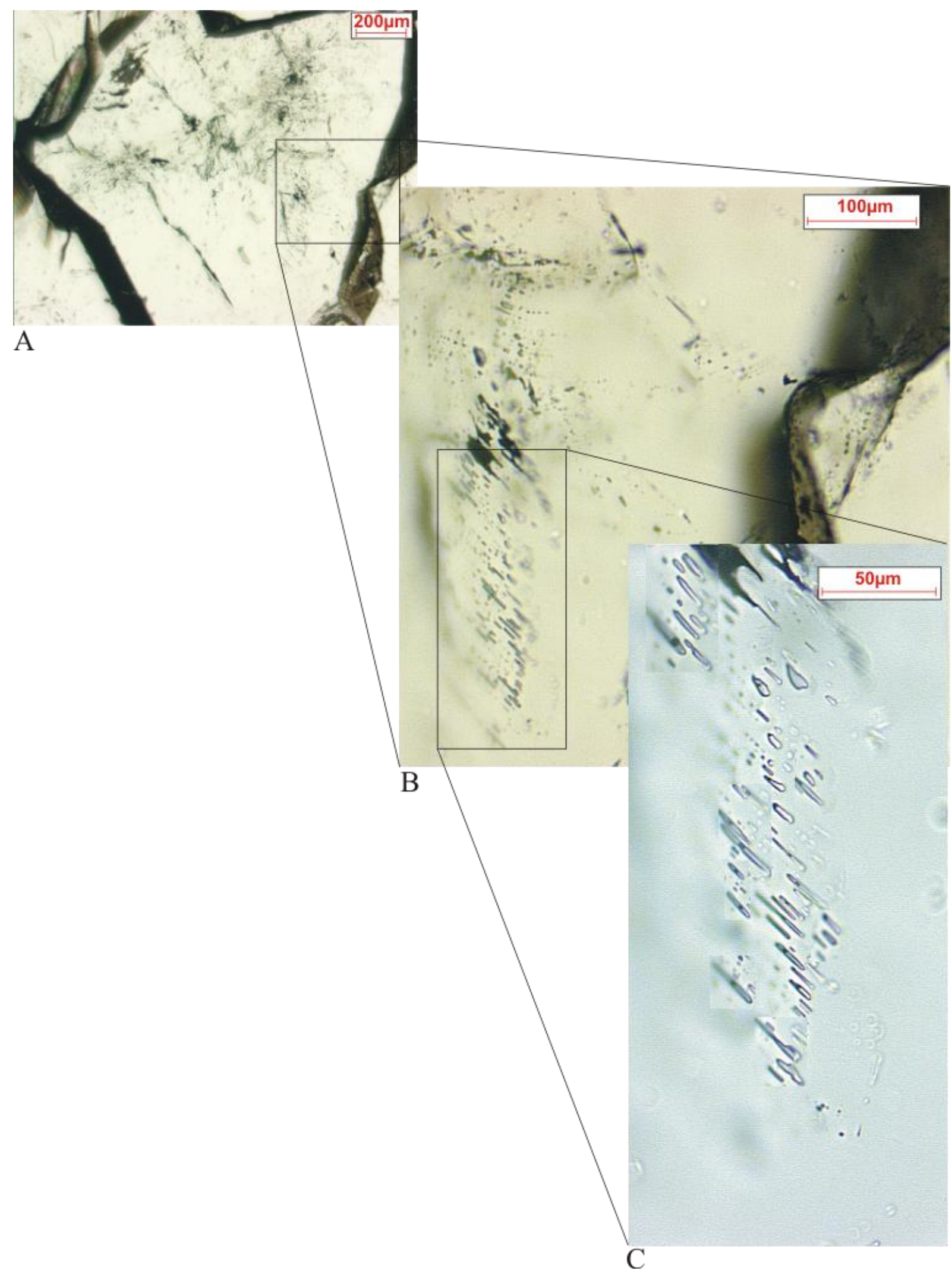

Figura 5.26: Trilha de inclusões fluidas pseudo-secundárias pertencentes ao Grupo III. As fotos correspondem ao campo L2-C1, que foi fotografado com auxílio de diferentes objetivas, permitindo desde a visualização da sua posição em relação ao cristal hospedeiro (A), até a observação das inclusões bifásicas $(\mathrm{C})$. 


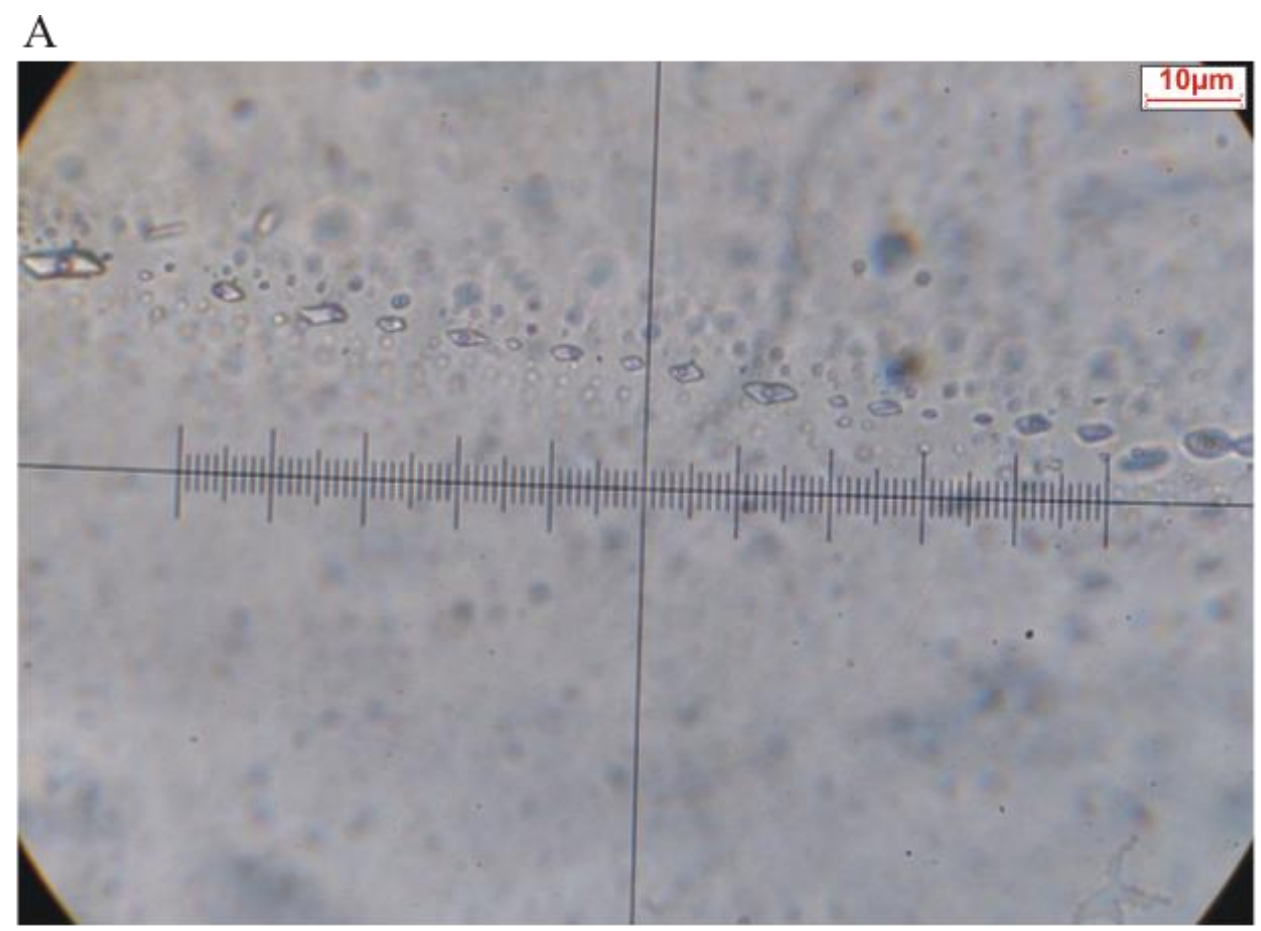

B

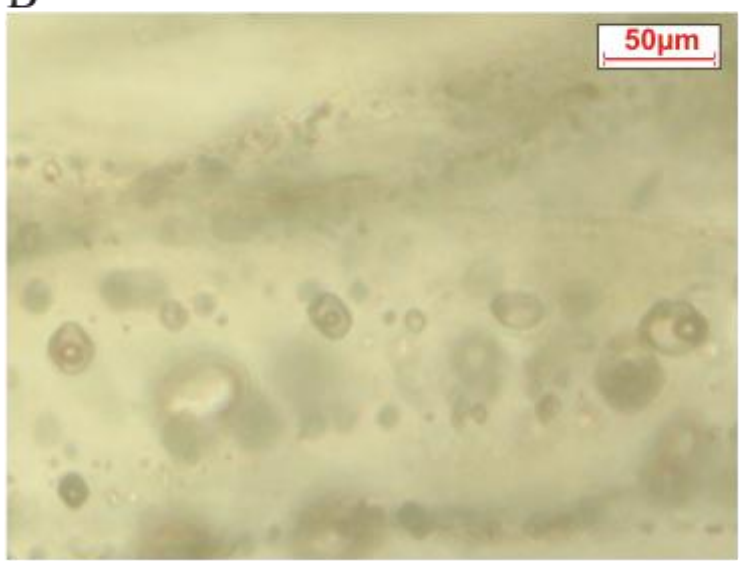

$\mathrm{D}$

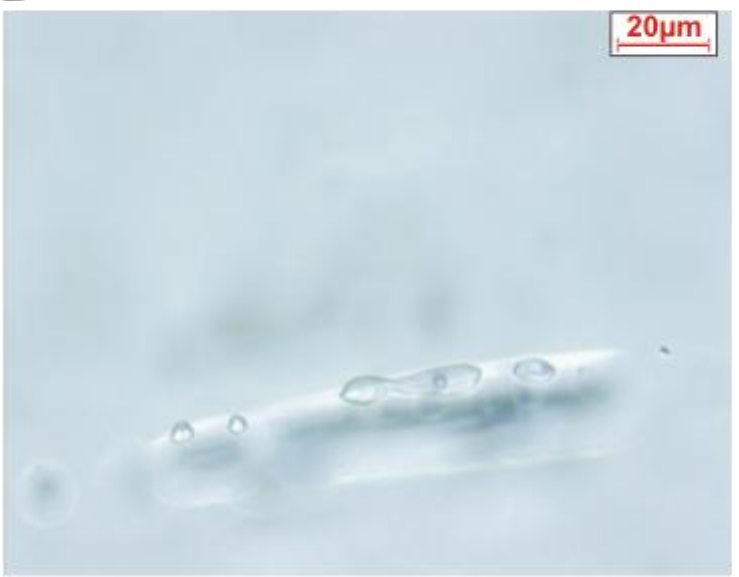

$\mathrm{C}$

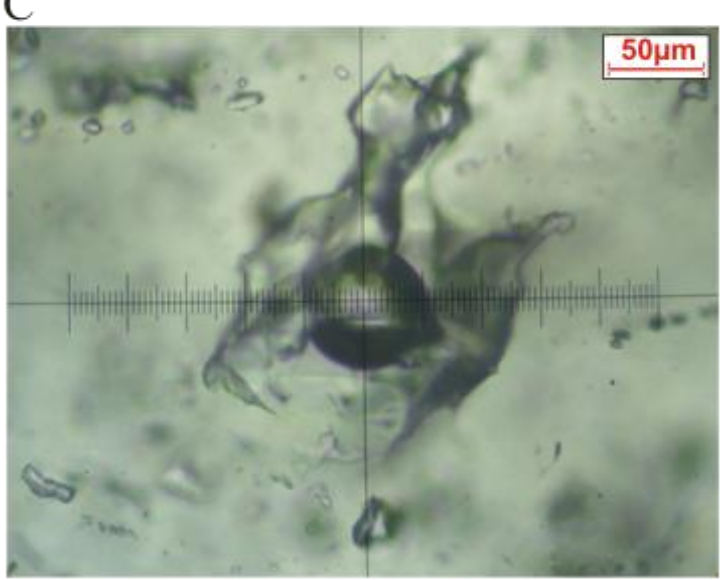

E

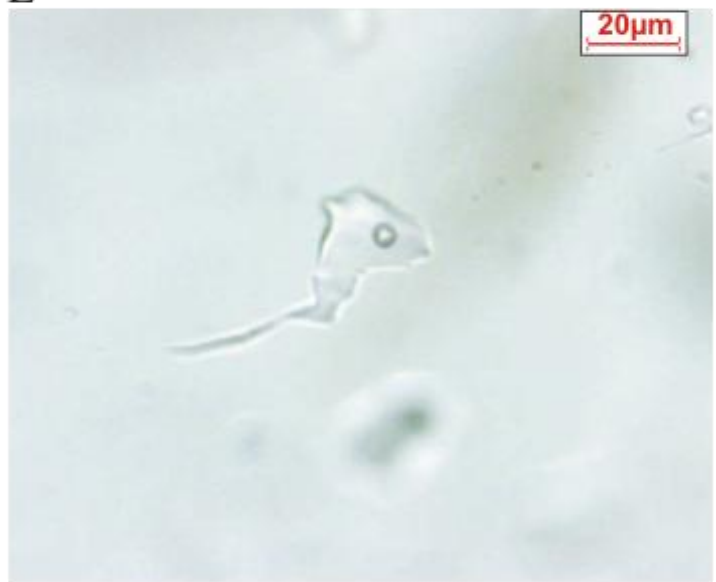

Figura 5.27: Fotomicrografias de inclusões fluidas pertencentes ao Grupo III. (A) e (B) Trilhas de inclusões fluidas pseudo-secundárias bifásicas associadas a monofásicas; (C) Inclusão fluida bifásica; (D) Possível feição de estrangulamento (necking down); (E) Inclusão fluida exibindo feição de escape de fluidos. 


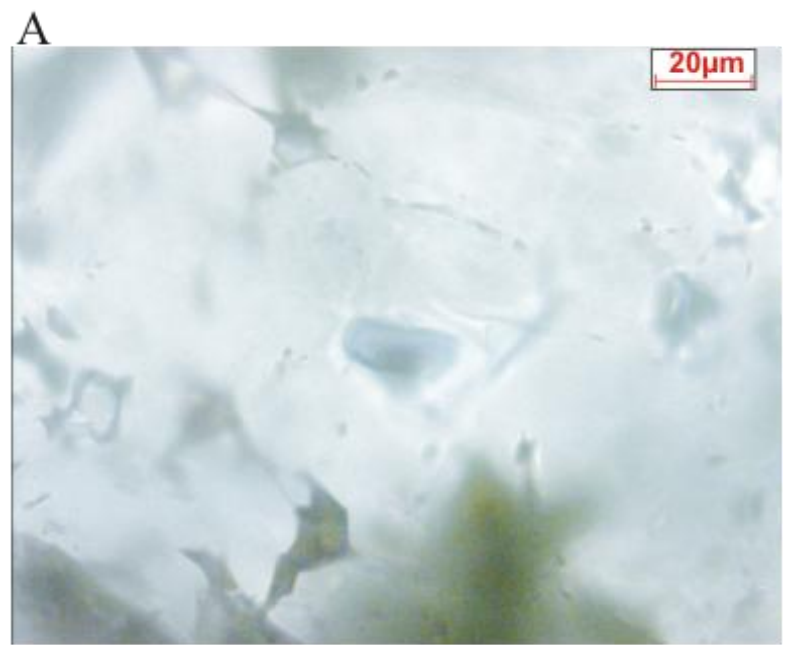

B

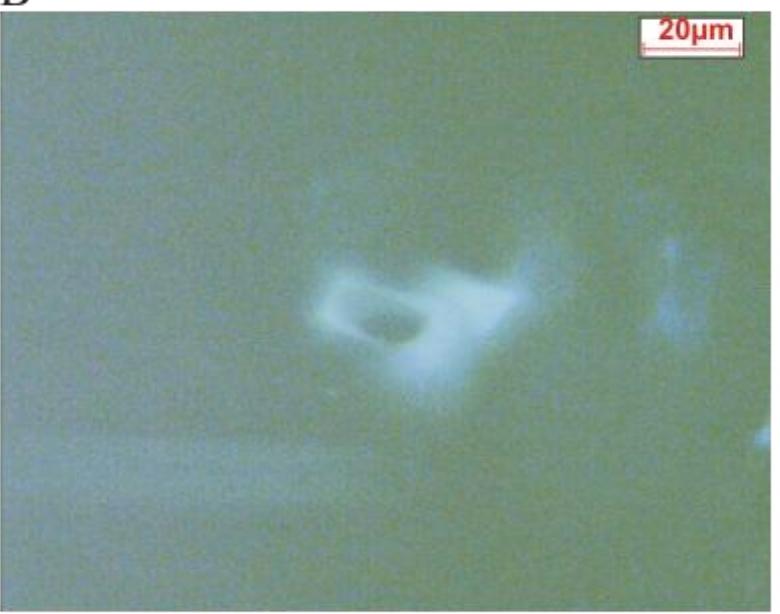

$\mathrm{C}$

D
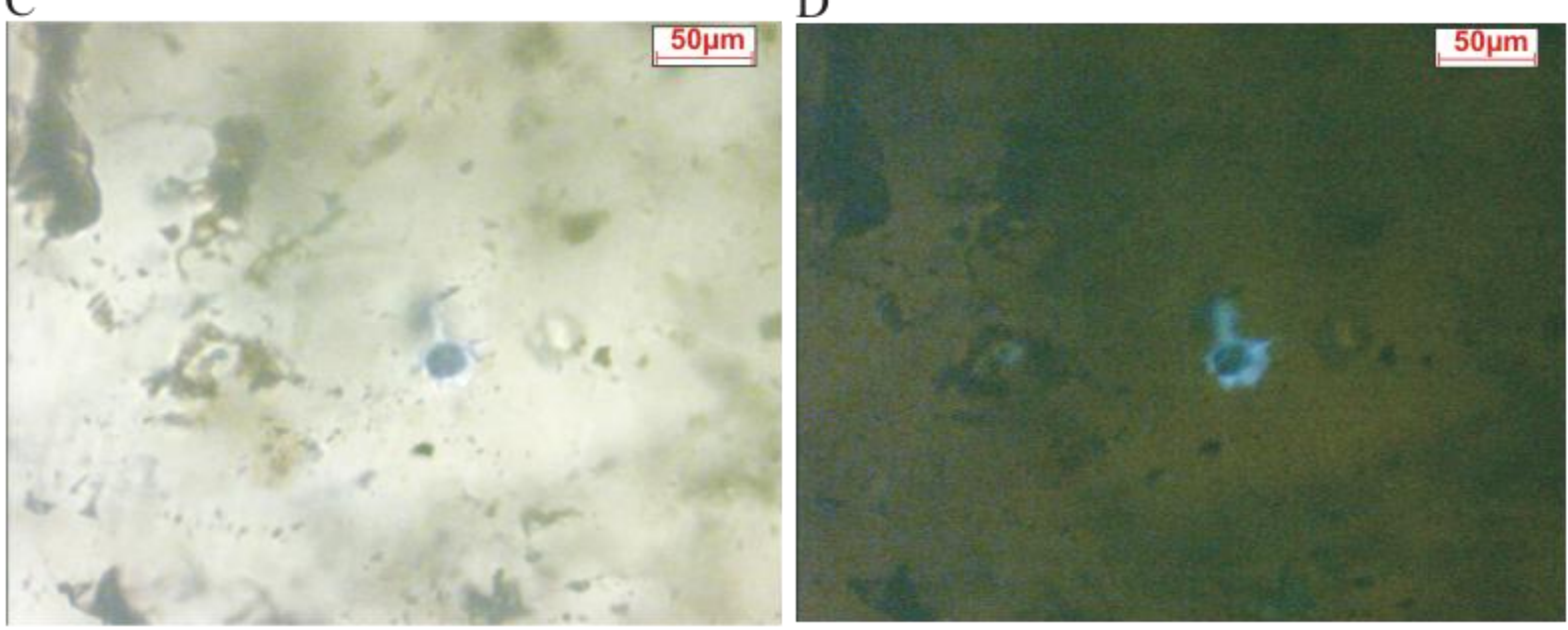

E $\mathrm{F}$
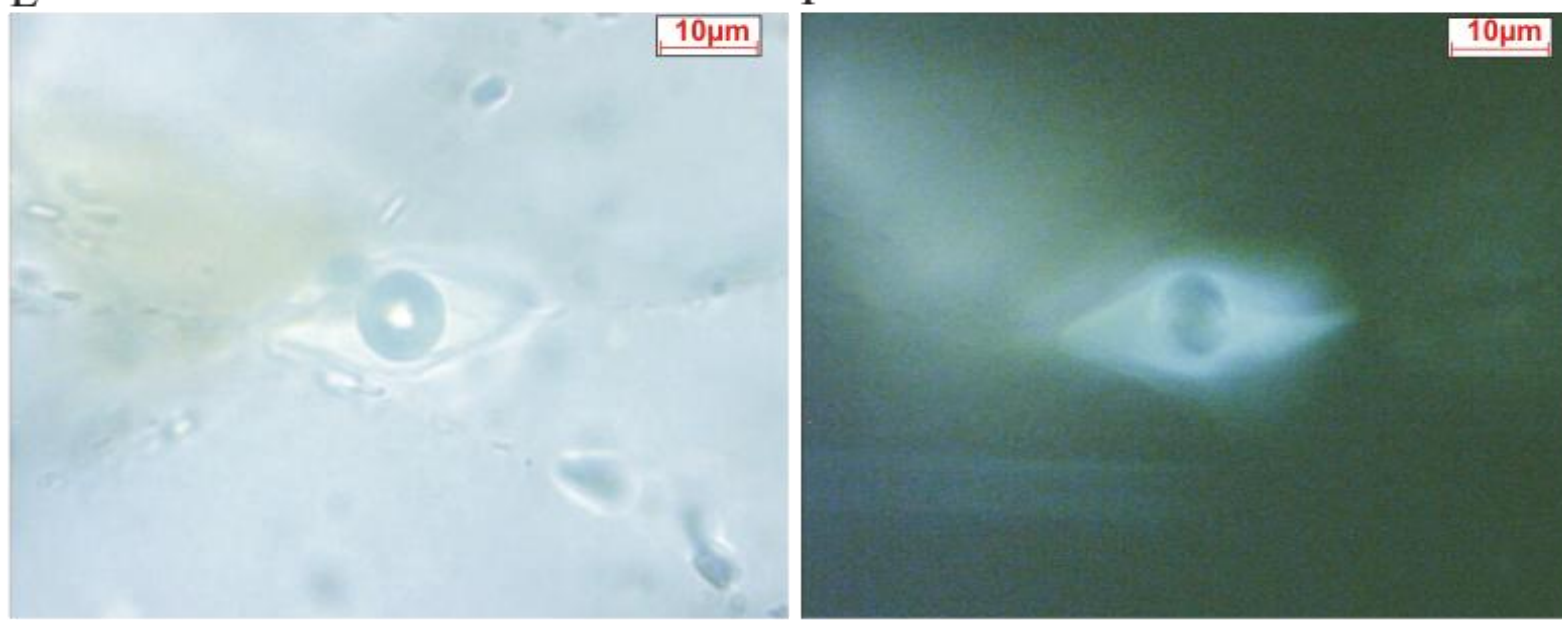

Figura 5.28: Fotomicrografias de inclusões fluidas pertencentes ao Grupo III. (A), (C) e (E) Inclusões fluidas compostas por hidrocarbonetos observadas em microscópio petrográfico com luz transmitida, e com luz ultravioleta (B), (D) e (F). Nota-se que as inclusões exibem fluorescência em tons azuis pálidos a esbranquiçados. 
A

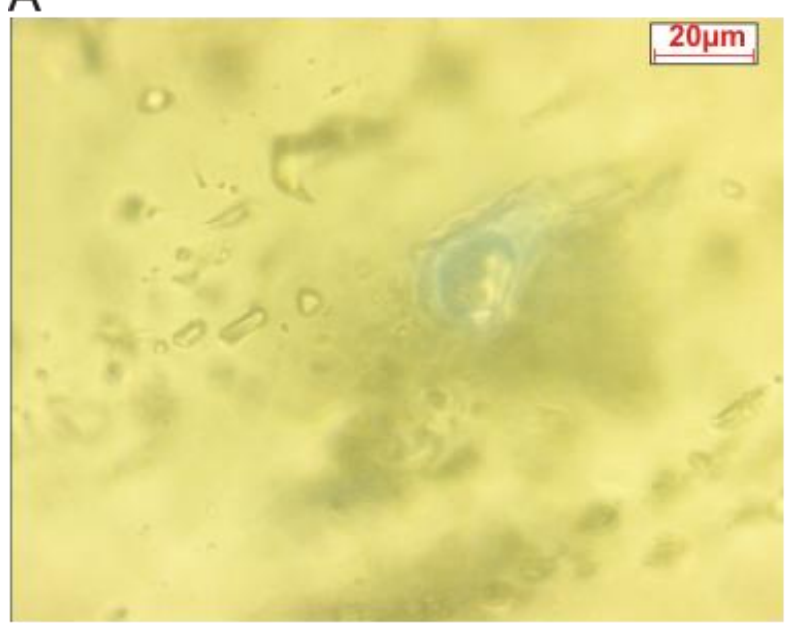

C

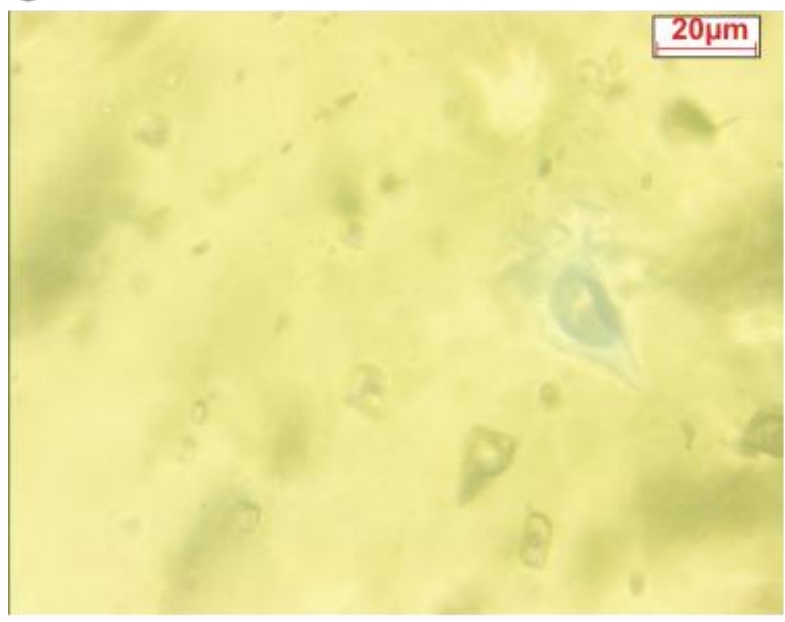

$E$

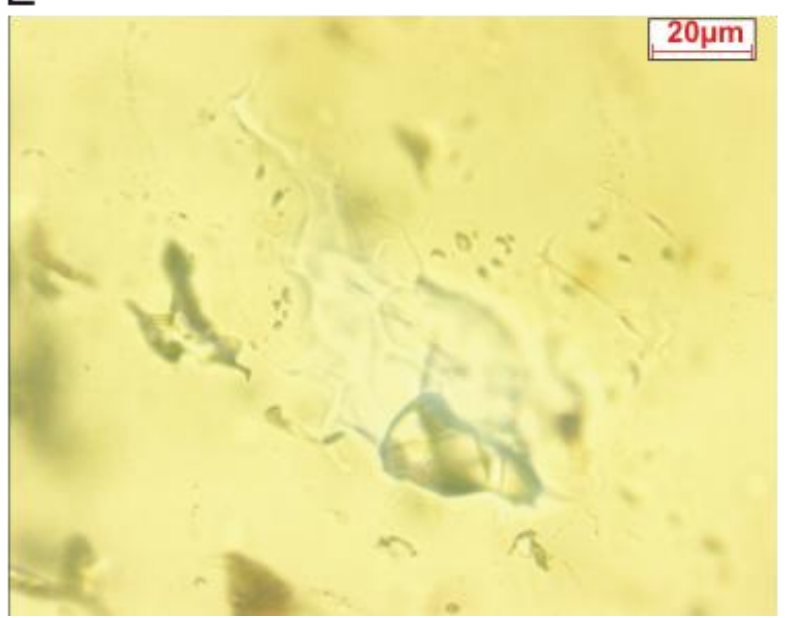

B

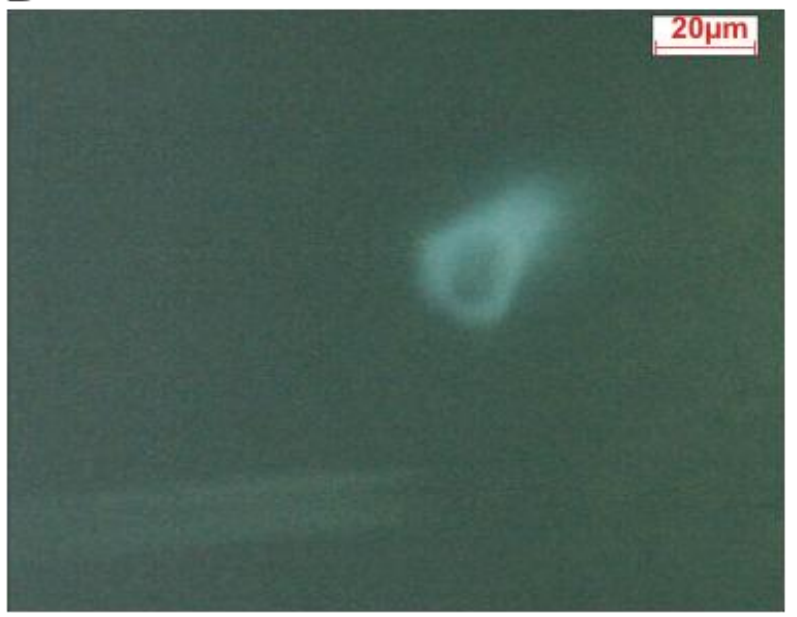

\section{D}

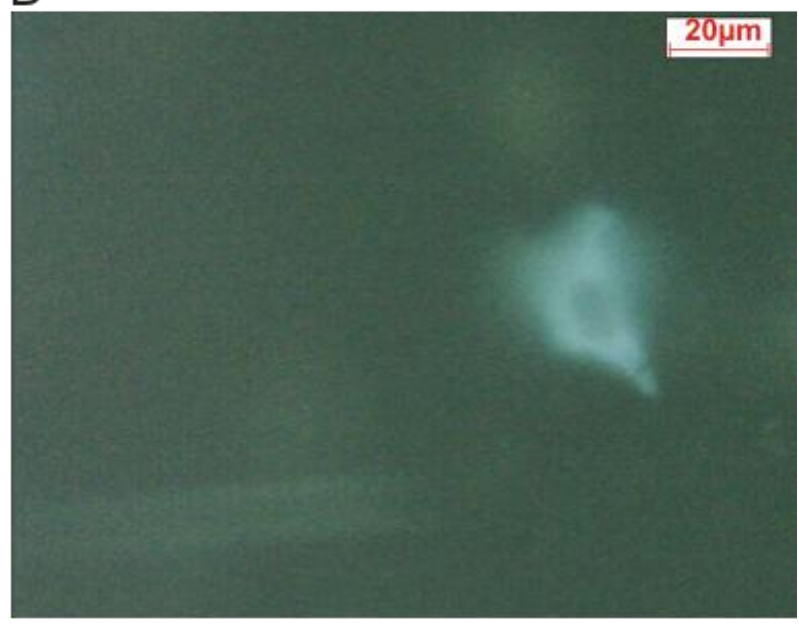

$\mathrm{F}$

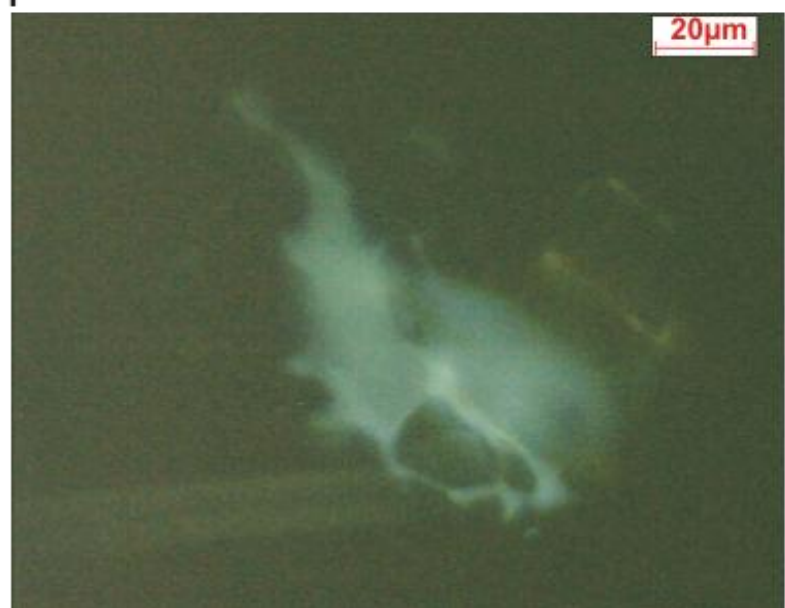

Figura 5.29: Fotomicrografias de inclusões fluidas pertencentes ao Grupo III. (A), (C) e (E) Inclusões fluidas compostas por hidrocarbonetos observadas em microscópio petrográfico com luz transmitida, e com luz ultravioleta (B), (D) e (F). Nota-se que as inclusões exibem fluorescência em tons azuis pálidos a esbranquiçados. 


\subsubsection{Dados microtermométricos}

Análises microtermométricas foram realizadas em 732 inclusões fluidas, o que permitiu a aquisição de 602 temperaturas de homogeneização total, 533 temperaturas de fusão do gelo e 360 temperaturas eutéticas. Essas temperaturas correspondem a mudanças de fases dos fluidos das inclusões e fornecem informações valiosas sobre as composições dos paleofluidos e as paleotemperaturas da Formação Irati na borda leste da Bacia do Paraná.

A tabela contendo todos os dados adquiridos nesse trabalho encontra-se no Anexo. A seguir são apresentados os resultados microtermométricos obtidos para cada grupo de inclusões.

\section{Grupo I}

Ensaios microtermométricos realizados em 119 inclusões fluidas hospedadas em veios de calcita espática na região de Cesário Lange (SP) demonstraram a existência de inclusões aquosas com temperaturas de homogeneização total, sempre para o líquido, situadas entre $69,9^{\circ}$ e $141,3^{\circ} \mathrm{C}$, com pico de frequência entre $100^{\circ}$ e $110^{\circ} \mathrm{C}$. A Figura 5.30A apresenta o histograma de frequência das temperaturas de homogeneização total desse grupo.

As temperaturas de fusão do gelo observadas em 93 inclusões fluidas encontram-se no intervalo entre $-4,5^{\circ}$ e $5,1^{\circ} \mathrm{C}$. Os $52 \%$ dos valores de temperaturas de fusão do gelo superiores a $0^{\circ} \mathrm{C}$ são indicativos de metaestabilidade e, portanto, de salinidades extremamente baixas. A Figura 5.30B exibe o histograma de frequência das temperaturas de fusão do gelo, sendo que o dado referente à temperatura de $5,1^{\circ} \mathrm{C}$ foi excluído por apresentar valor muito alto e inconstante durante a repetição da medida, devido ao comportamento metaestável da inclusão. As salinidades variaram de 0,23 a 7,27\% em peso de $\mathrm{NaCl}$ equivalente.

As temperaturas eutéticas de 73 inclusões fluidas variaram entre $-53,9^{\circ}$ e $-36,0^{\circ} \mathrm{C}$, sendo que a maior parte está contida no intervalo de $-53,9^{\circ}$ e $-43,8^{\circ} \mathrm{C}$, o que sugere um sistema composto por $\mathrm{H}_{2} \mathrm{O}+\mathrm{NaCl}+\mathrm{CaCl}_{2}$. Esses resultados provêm de estudos experimentais nesse sistema realizados por Davis et al. (1990) que atribuíram eutéticos estáveis de $-52^{\circ} \mathrm{C}$, embora tenham obtido valores ora mais baixos, ora mais elevados (de $-90^{\circ} \mathrm{a}-47^{\circ} \mathrm{C}$ ).

Goldstein \& Reynolds (1994) e Roedder (1984) discutem que valores de temperatura eutética menores que $-40^{\circ} \mathrm{C}$ já podem significar sistema contendo íons bivalentes $(\mathrm{Ca}$ e/ou $\mathrm{Mg}$ ). Esses valores também podem indicar um sistema onde está presente o $\mathrm{MgCl}_{2}+\mathrm{NaCl}+\mathrm{H}_{2} \mathrm{O}$ que possuem eutético estável em $-35^{\circ} \mathrm{C}$, embora existam valores de $-80^{\circ}$ a $-33^{\circ} \mathrm{C}$ (Davis et al.,1990). 
A Figura 5.30C apresenta o histograma de frequências das temperaturas eutéticas observadas nesse grupo, sendo que o dado de $-36,0^{\circ} \mathrm{C}$ foi excluído do histograma por ser bastante distinto dos demais. Esse valor pode não ser real e sim decorrente da dificuldade de observação desse processo em muitas inclusões.

\section{Grupo II}

Ensaios microtermométricos realizados em 205 inclusões fluidas hospedadas em veio de calcita espática da região de Paraisolândia (SP) demonstraram a existência de inclusões aquosas com temperaturas de homogeneização total, para o líquido, situadas entre $73,5^{\circ} \mathrm{e}$ $225,7^{\circ} \mathrm{C}$, com pico de frequência entre $140^{\circ}$ e $150^{\circ} \mathrm{C}$. A Figura $5.31 \mathrm{~A}$ apresenta o histograma de frequência das temperaturas de homogeneização desse grupo. Cerca de $4 \%$ das inclusões fluidas desse grupo apresentaram temperaturas acima de $200^{\circ} \mathrm{C}$. Tendo em vista que essas inclusões apresentaram o volume calculado da fase vapor acima do volume medido antes da etapa do aquecimento, existe a possibilidade de que as inclusões tenham sofrido vazamento, com aumento da fase vapor e aumento da temperatura de homogeneização total por consequência. Contudo, como o histograma de frequência das temperaturas de homogeneização total exibe um comportamento relativamente semelhante ao de uma distribuição gaussiana, optamos por não excluir esse conjunto de dados do histograma.

As temperaturas de fusão do gelo observadas em 166 inclusões fluidas encontram-se no intervalo entre $-1,9^{\circ} \mathrm{e}+4,3^{\circ} \mathrm{C}$. Os $33 \%$ dos valores de temperaturas de fusão do gelo superiores a $0^{\circ} \mathrm{C}$ são indicativos de metaestabilidade e, por conseguinte, de salinidades extremamente baixas. A Figura 5.31B exibe o histograma de frequência das temperaturas de fusão do gelo, sendo que os dados referentes às temperaturas de $3,4^{\circ}$ e $4,3^{\circ} \mathrm{C}$ não foram incluídos por apresentarem valores elevados e variáveis com a repetição do processo, devido a fenômenos de metaestabilidade. A salinidade dos fluidos apresenta valores desde $\sim 0$ a 3,26\% em peso de $\mathrm{NaCl}$ equivalente.

As temperaturas eutéticas de 78 inclusões fluidas variaram entre $-56,8^{\circ}$ e $-49,3^{\circ} \mathrm{C}$, indicando um sistema composto por $\mathrm{H}_{2} \mathrm{O}+\mathrm{NaCl}+\mathrm{CaCl}_{2}$. A Figura 5.31C apresenta o histograma de frequências das temperaturas eutéticas observadas nesse grupo. 


\section{Grupo III}

Ensaios microtermométricos realizados em 278 inclusões fluidas hospedadas em veio de quartzo da região de Paraisolândia (SP) demonstraram a existência de inclusões aquosas com homogeneização total sempre para o líquido e em temperaturas situadas entre $61,9^{\circ}$ e $412,7^{\circ} \mathrm{C}$, com pico de frequência entre $120^{\circ}$ e $130^{\circ} \mathrm{C}$. Contudo, os quatro dados acima de $300^{\circ} \mathrm{C}$, a saber, $307,5^{\circ} \mathrm{C}, 312,9^{\circ} \mathrm{C}, 362,1^{\circ} \mathrm{C}$ e $412,7^{\circ} \mathrm{C}$ não foram considerados no histograma, pois eventualmente podem ser representativos de que as inclusões sofreram modificações por escape de fluidos, com aumento da fase vapor e aumento da temperatura de homogeneização total. A Figura 5.32A apresenta o histograma de frequência das temperaturas de homogeneização desse grupo.

As temperaturas de fusão do gelo observadas em 274 inclusões fluidas encontram-se no intervalo entre $-18,5^{\circ}$ e $5,5^{\circ} \mathrm{C}$. Os $10 \%$ dos valores de temperatura superiores a $0^{\circ} \mathrm{C}$ são indicativos de metaestabilidade e salinidades extremamente baixas. A Figura 5.32B exibe o histograma de frequência das temperaturas de fusão do gelo, sendo que os dados referentes às temperaturas de $4,9^{\circ} \mathrm{e} 5,5^{\circ} \mathrm{C}$ não foram incluídos por apresentarem valores variáveis com a repetição da medida, devido a fenômenos de metaestabilidade, e foram interpretados como representativos de salinidades baixas. Os fluidos apresentam salinidades variando desde valores próximos a 0 a $21,67 \%$ em peso de $\mathrm{NaCl}$ equivalente.

As temperaturas eutéticas de 209 inclusões fluidas (Figura 5.32C) variaram entre 58,7 e $-40,0^{\circ} \mathrm{C}$, o que sugere um sistema composto por $\mathrm{H}_{2} \mathrm{O}+\mathrm{NaCl}+\mathrm{CaCl}_{2}$. 


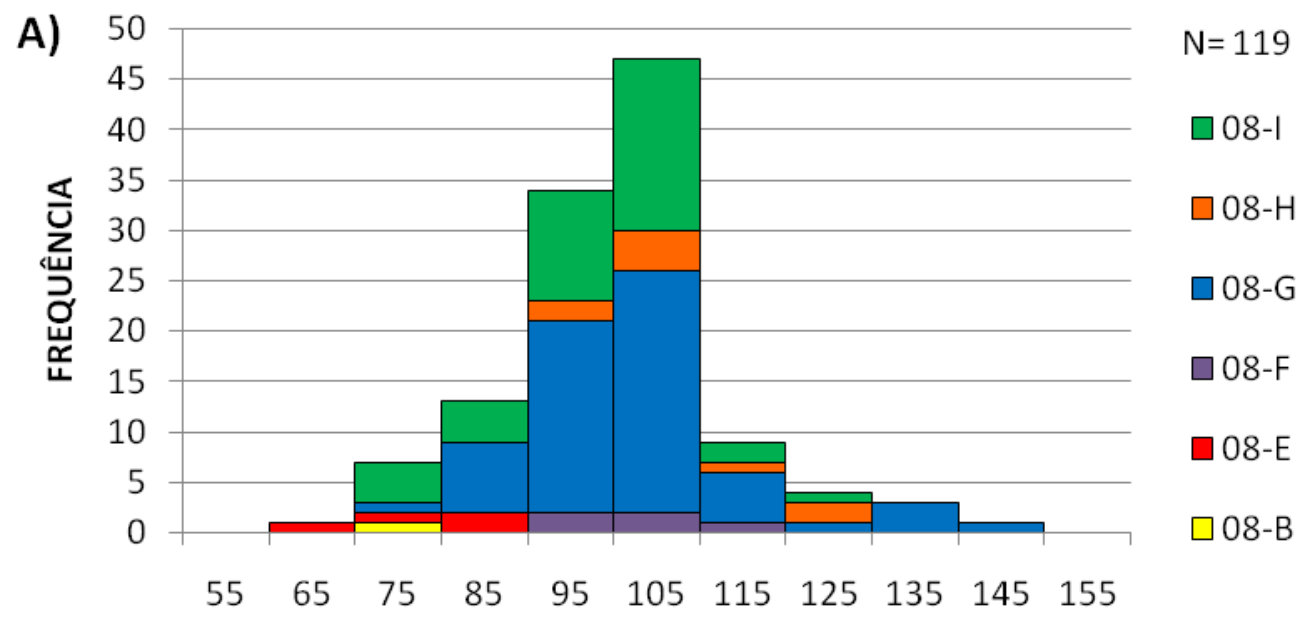

Temperatura de homogeneização total $\left({ }^{\circ} \mathrm{C}\right)$

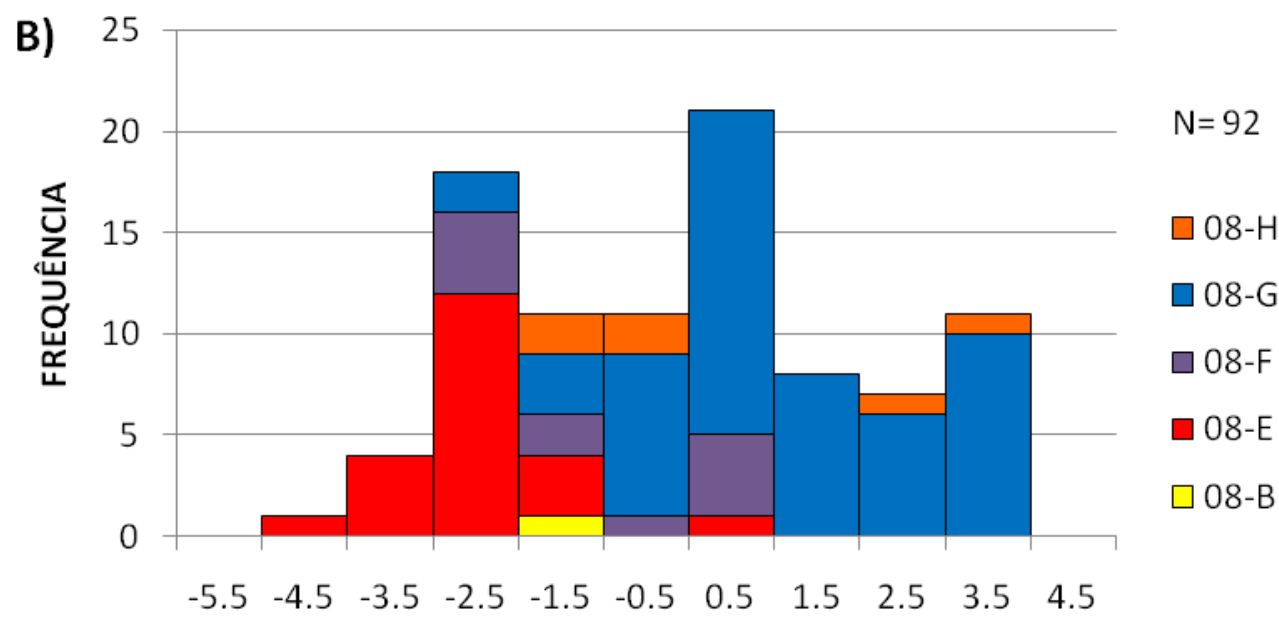

Temperatura de fusão do gelo $\left({ }^{\circ} \mathrm{C}\right)$

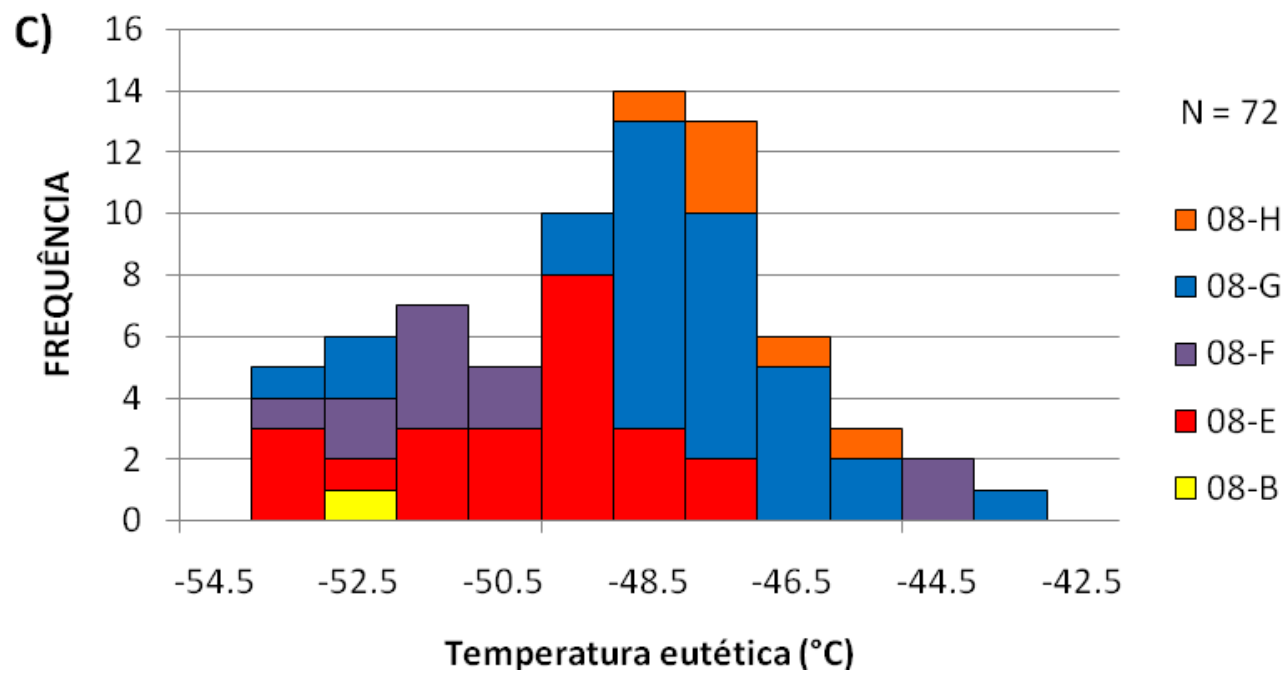

Figura 5.30: Histogramas de frequência das temperaturas de mudanças de fases em inclusões fluidas pertencentes ao Grupo I (hospedadas em veios de calcita espática da região de Cesário Lange). (A)

Temperaturas de homogeneização total. (B) Temperaturas de fusão do gelo. (C) Temperaturas eutéticas. 

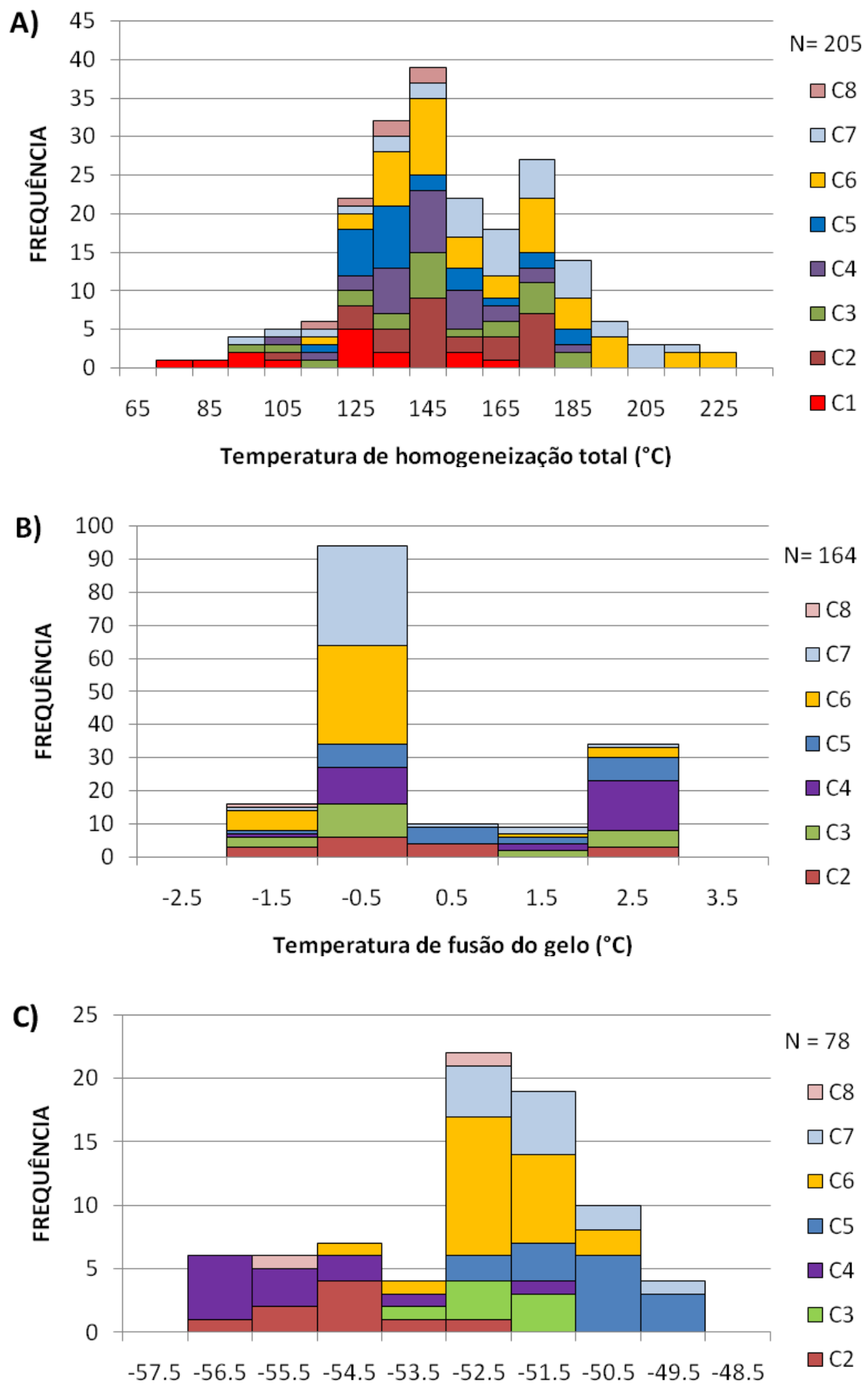

Temperatura eutética $\left({ }^{\circ} \mathrm{C}\right)$

Figura 5.31: Histogramas de frequência das temperaturas de mudanças de fases em inclusões fluidas pertencentes ao Grupo II (hospedadas em veio de calcita espática da região de Paraisolândia). (A) Temperaturas de homogeneização total. (B) Temperaturas de fusão do gelo. (C) Temperaturas eutéticas. 


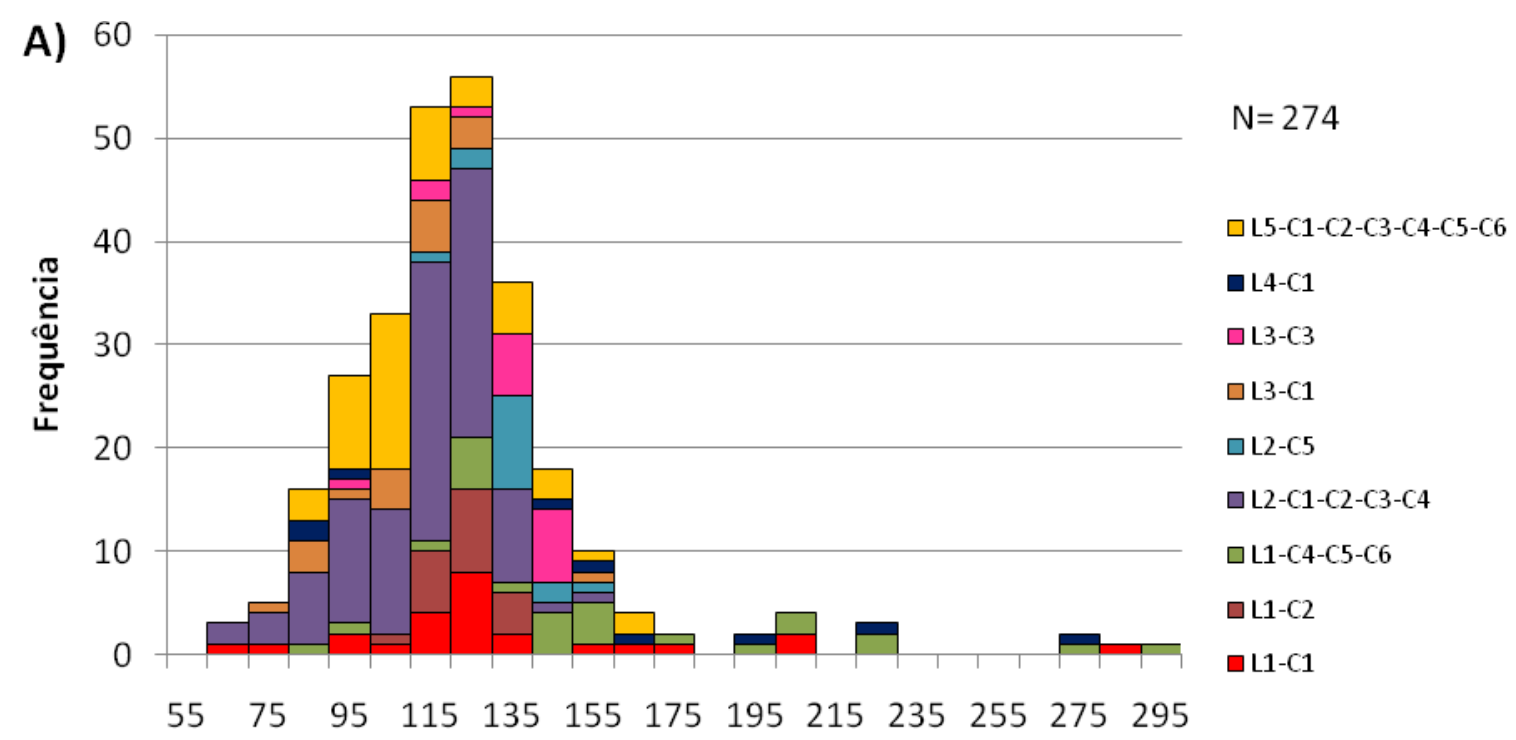

Temperatura de homogeneização total $\left({ }^{\circ} \mathrm{C}\right)$

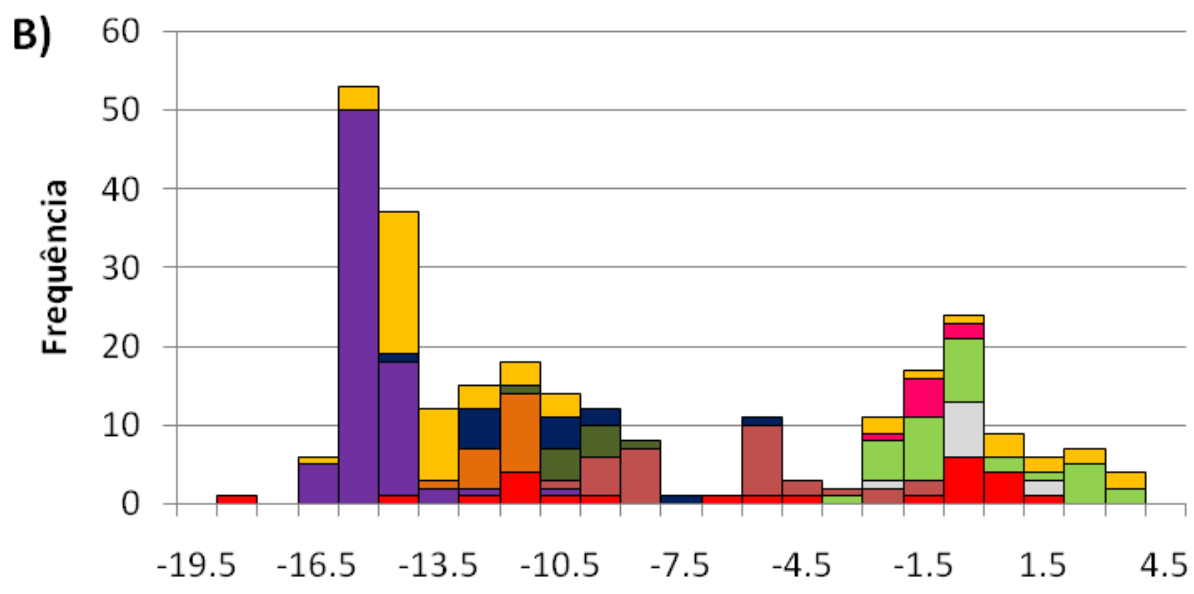

$N=272$

口L5-C1-C2-C3-C4-C5-C6

- L4-C1

ㄴ3-C3

口L3-C2

ㄴ. 3-C1

ㄴ2-C5

- $22-C 1-C 2-C 3-C 4$

口L1-C4-C5-C6

$\square \mathrm{L1}-\mathrm{C3}$

ㄴL1-C2

aL1-C1

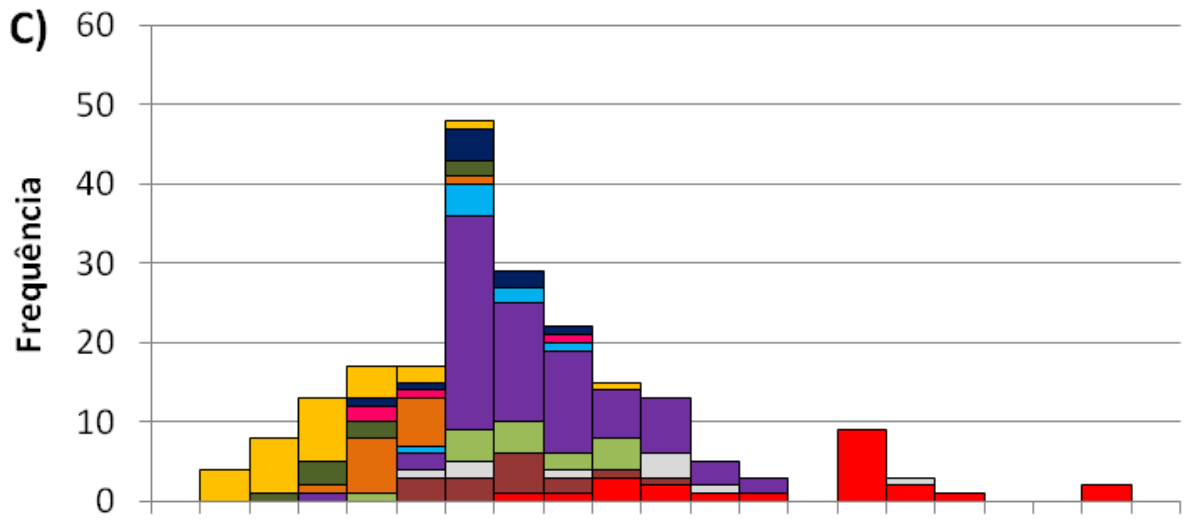

$N=209$

$\square \mathrm{L} 5-\mathrm{C} 1-\mathrm{C2}-\mathrm{C} 3-\mathrm{C} 4-\mathrm{C} 5-\mathrm{C} 6$

- L4-C1

口L3-C3

$\square \mathrm{L} 3-\mathrm{C} 2$

ㅁ3-C1

$\square \mathrm{L} 2-\mathrm{C5}$

- L2-C1-C2-C3-C4

口L1-C4-C5-C6

ㅁ1-C3

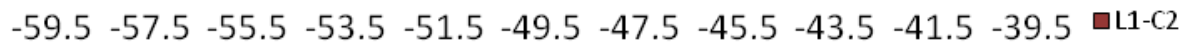

Temperatura eutética $\left({ }^{\circ} \mathrm{C}\right)$

-L1-C1

Figura 5.32: Histogramas de frequência das temperaturas de mudanças de fases em inclusões fluidas pertencentes ao Grupo III (hospedadas em veio de quartzo da região de Paraisolândia). (A) Temperaturas de homogeneização total. (B) Temperaturas de fusão do gelo. (C) Temperaturas eutéticas. 


\section{DISCUSSÕES}

\subsection{Concentração de carbono orgânico e potencial de geração de hidrocarbonetos}

A acumulação da matéria orgânica acontece de forma concomitante à deposição de rochas sedimentares, sob a forma de matéria orgânica disseminada. De modo geral, quanto maior a quantidade de matéria orgânica, maior será sua capacidade de gerar grandes concentrações de petróleo. No entanto, além da incorporação da matéria orgânica nos ambientes sedimentares, é imprescindível que haja a preservação dos compostos ricos em carbono e hidrogênio, tais como lipídios. Ambientes anóxicos favorecem a preservação da matéria orgânica (Hunt, 1995; Allen \& Allen, 2005).

O carbono orgânico total (COT) corresponde à quantidade de matéria orgânica presente nas rochas sedimentares e está relacionado com a fácies orgânica (ambiente deposicional), grau de evolução térmica e presença de hidrocarbonetos. Segundo Peters \& Cassa (1994), a partir do conteúdo de COT, é possível classificar o potencial de geração de hidrocarbonetos das rochas (Tabela 6.1). Contudo, o COT não diferencia o potencial para geração de óleo e gás. Rochas com alto COT, mas cuja matéria orgânica deriva de plantas, por exemplo carvão, tem potencial alto para gerar gás, mas baixo potencial para geração de óleo.

Tabela 6.1- Classificação do potencial de geração de hidrocarbonetos de acordo com o teor de carbono orgânico (em porcentagem massa) (Peters \& Cassa, 1994).

\begin{tabular}{|ll|}
\hline Potencial de Geração & COT (\%) \\
\hline Baixo & $0-0,5$ \\
\hline Médio & $0,5-1,0$ \\
\hline Alto & $1,0-2,0$ \\
\hline Muito alto & $2,0-4,0$ \\
\hline Excelente & $>4,0$ \\
\hline
\end{tabular}

Os folhelhos da Formação Irati, no Estado de São Paulo, apresentam potencial de geração alto a muito alto, segundo a classificação de Peters \& Cassa (1994), à exceção do ponto 3, (amostra IP-40) que apresenta baixo potencial, possivelmente devido ao craqueamento térmico proporcionado pela intrusão de soleira associada ao magmatismo Serra 
Geral, com a conversão e/ou eliminação de carbono orgânico sob a forma de hidrocarboneto (Silva, 2007), e pontos 5 (IP-30) e 6 (IP-31) nos quais o potencial de geração é considerado excelente.

No Estado do Paraná, os teores de COT permitem atribuir aos folhelhos da Formação Irati um excelente potencial de geração. As médias dos teores de carbono orgânico total de 2,46\%, para o Estado de São Paulo, e 11,32\% para as amostras do Estado do Paraná, são semelhantes às médias encontradas por Araújo et al. (2000).

De acordo com esses resultados, pode-se observar que a sul do Arco de Ponta Grossa os folhelhos são mais ricos em COT do que a norte, onde ocorrem intercalados com rochas carbonáticas. Esse comportamento sugere controle deposicional sobre o teor de carbono orgânico. Neste caso, o ambiente mais restrito de menor circulação a norte (Figura 2.5) não seria o fator mais importante, considerando-se que essa restrição poderia favorecer condições anóxicas de fundo. Eventualmente, o fato de a porção norte ser mais rasa (evidenciada pela presença de carbonatos) teria dificultado as condições de anoxia das águas de fundo. Além disso, o clima mais árido e as condições hipersalinas a norte, indicadas pela ocorrência de evaporitos, reduziriam a produtividade orgânica (Hachiro, 2000).

A variação da concentração de carbono orgânico ao longo das seções colunares (figuras 5.19 e 5.20) foi pouco significativa.

As amostras pertencentes às formações Serra Alta (IP-01 e IP-02) e Corumbataí (IP29) revelaram que nas localidades estudadas, essas unidades apresentam baixo potencial gerador.

Nas duas seções em que as concentrações de teor de carbono orgânico e enxofre foram estudadas em maior detalhe (pontos 8 e 9), pode-se notar certa correlação entre esses parâmetros (Figura 5.19), sugerindo um possível controle deposicional para as acumulações da enxofre.

Os teores de enxofre encontrados nos folhelhos da Formação Irati no Estado de São Paulo são menores do que os observados no Estado do Paraná, possivelmente devido às condições mais redutoras nesse ambiente deposicional.

Quando um querogênio é enriquecido em enxofre (>6\%), a geração de hidrocarbonetos é facilitada, pois há uma redução na energia térmica necessária para a geração de hidrocarbonetos (Orr, 1985; Horsfield \& Rullkotter, 1994). Entretanto, os baixos teores encontrados para as amostras analisadas, sugerem que, eventualmente, o enxofre não tenha 
contribuído para a redução da energia térmica necessária para a geração de hidrocarbonetos a partir dos folhelhos da Formação Irati nas áreas de estudo.

\subsection{Paleofluidos e Paleotemperaturas da Formação Irati}

As temperaturas eutéticas dos três grupos de inclusões fluidas estudadas (Figura 6.1A) indicam, que os fluidos aquosos aprisionados exibem a mesma composição, $\mathrm{H}_{2} \mathrm{O}+\mathrm{NaCl}+\mathrm{CaCl}_{2}$, podendo também conter $\mathrm{MgCl}_{2}$. Segundo Crawford \& Hollister (1992), inclusões fluidas em carbonatos (grupos I e II) podem ter sua composição original modificada, adquirindo, por exemplo, o $\mathrm{Ca}^{2+}$ e/ou o $\mathrm{Mg}^{2+}$ devido a trocas iônicas entre o fluido e o mineral hospedeiro. Desse modo, o fluido original seria constituído por $\mathrm{NaCl}$ e $\mathrm{H}_{2} \mathrm{O}$ enquanto que o $\mathrm{CaCl}_{2}$ e o $\mathrm{MgCl}_{2}$ ou já estão no fluido original ou provêm de trocas iônicas dessas soluções com o carbonato hospedeiro. No entanto, como as inclusões contidas no veio de quartzo também apresentam $\mathrm{CaCl}_{2}$ e/ou $\mathrm{MgCl}_{2}$, isto sugere que esses compostos já estavam presentes nos fluidos aquosos originais.

Observando os histogramas de salinidade, nota-se que os veios de calcita espática hospedam inclusões com fluidos de salinidade mais baixa, desde aproximadamente 0 a 3,26\% em peso de $\mathrm{NaCl}$ equivalente (Grupo II) e entre 0,23 e 7,27\% em peso de $\mathrm{NaCl}$ equivalente (Grupo I), enquanto, os veios de quartzo (Grupo III), apresentam inclusões fluidas com salinidades mais elevadas e variadas, de aproximadamente 0 a 21,67\% em peso de $\mathrm{NaCl}$ equivalente. As inclusões fluidas contidas em quartzo apresentam um conjunto de dados com valores compatíveis aos observados nas inclusões em calcita e outro conjunto com salinidades mais altas (Figura 6.1B), o que sugere uma possível mistura destes dois tipos de fluidos.

Quando partículas finas (silte e argila) se depositam, grande quantidade de água é aprisionada em meio a esses sedimentos. Esta água aprisionada nos poros do folhelho tem sua salinidade aumentada devido às reações com os minerais do folhelho durante o soterramento. Sendo assim, a salinidade da água dos poros depende tanto do ambiente deposicional, quanto das reações que ocorrem durante o soterramento. Interpreta-se que o fluido de salinidade mais alta que estivesse presente nos poros do folhelho gerador tenha migrado juntamente com o hidrocarboneto através de microfraturas na rocha geradora. Segundo Lisboa (2006), biomarcadores sugerem a deposição dos folhelhos da Formação Irati situados na borda leste da Bacia do Paraná em ambiente marinho de elevada salinidade.

Por outro lado, o fluido de menor salinidade é possivelmente composto por água meteórica. E caso este fluido circulasse por fraturas subverticais, isso seria altamente prejudicial para a preservação dos hidrocarbonetos, podendo causar sua degradação. 

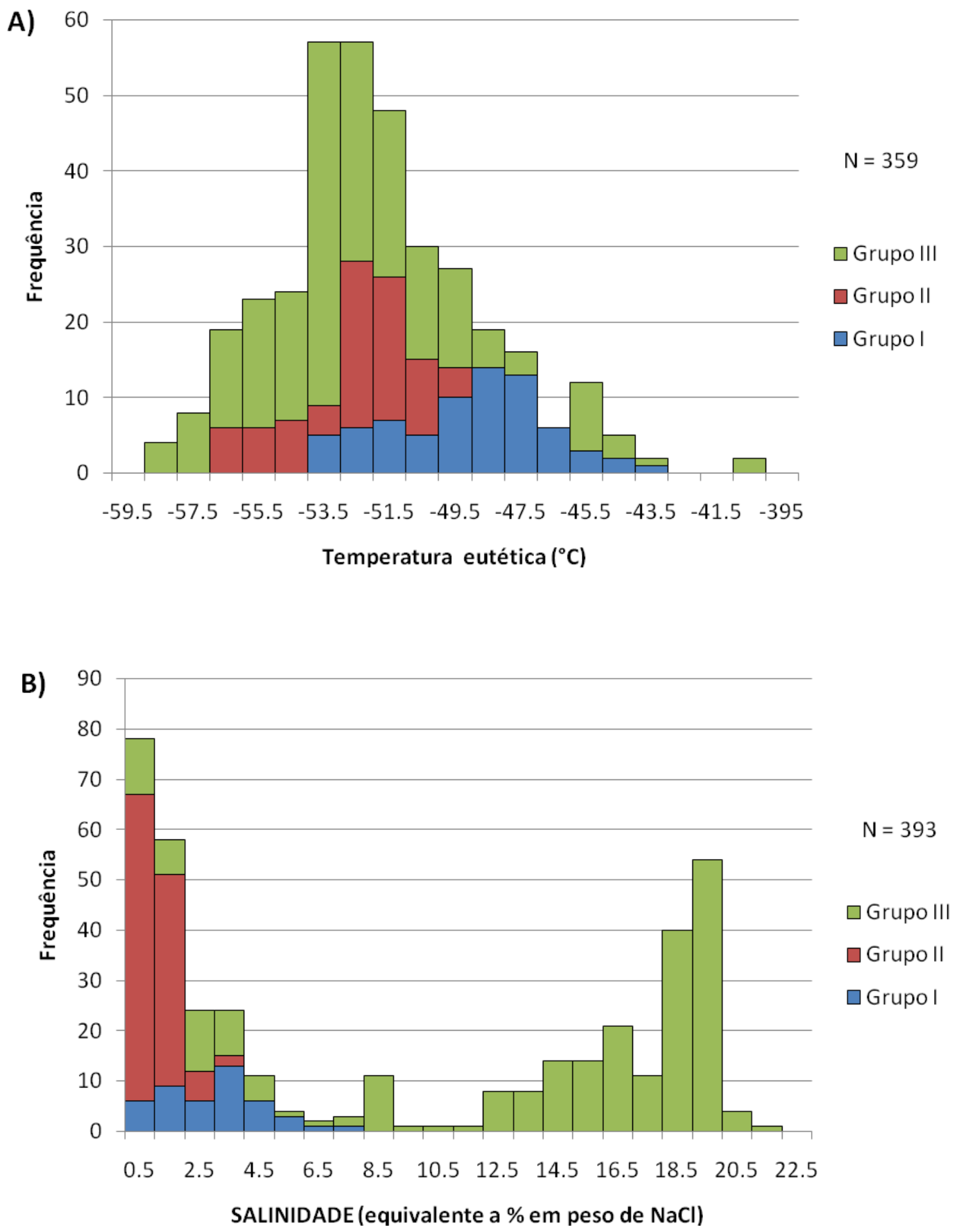

Figura 6.1: Paleofluidos da Formação Irati. (A) Histograma de frequência das temperaturas eutéticas. (B) Salinidades. O Grupo I é constituído por inclusões fluidas hospedadas em veios de calcita espática na região de Cesário Lange (SP), enquanto, os grupos II e III correspondem a inclusões fluidas contidas em veio de calcita espática e veio de quartzo, respectivamente, nos arredores de Paraisolândia (SP). 
As paleotemperaturas obtidas neste trabalho (Figura 6.2), situadas frequentemente entre $60^{\circ}$ e $230^{\circ} \mathrm{C}$ (mas podendo alcançar valores mais altos, de até $410^{\circ} \mathrm{C}$ ) referentes à homogeneização de inclusões fluidas pertencentes aos grupos II e III, hospedadas respectivamente em veio de calcita espática e de quartzo da Formação Irati, próximo à região de Paraisolândia, em seção afetada por intrusão de soleira de basalto com pelo menos três metros de espessuras e também às do Grupo I (hospedadas em veios de calcita espática de Cesário Lange), são semelhantes às paleotemperaturas obtidas por Fuzikawa (1994) e Castro et al. (2004) que investigaram temperaturas de homogeneização (TH) de inclusões fluidas em amostras da Formação Irati afetadas pela intrusão de soleiras associadas ao magmatismo Serra Geral. Fuzikawa (1994 apud Araújo et al., 2000), que estudou inclusões fluidas aquosas e de hidrocarboneto hospedadas em veios de quartzo e de calcita de seções da Formação Irati, obteve medidas de $\mathrm{TH}$ de inclusões aquosas situadas entre $40^{\circ}$ e $240^{\circ} \mathrm{C}$, e $\mathrm{TH}$ variando de $60^{\circ} \mathrm{C}$ a $260^{\circ} \mathrm{C}$ para inclusões de hidrocarboneto na seção intrudida por soleira com $20,6 \mathrm{~m}$ de espessura. Segundo esse autor, para esta seção, as medidas de homogeneização mais altas (tanto das aquosas como das de hidrocarbonetos) foram obtidas nas inclusões fluidas das amostras coletadas mais próximas da soleira. Na segunda seção, intrudida por soleira com 27,2 metros, foram encontradas temperaturas de homogeneização situadas entre $40^{\circ}$ e $150^{\circ} \mathrm{C}$, sendo que as temperaturas de homogeneização entre $50^{\circ}$ e $70^{\circ} \mathrm{C}$ referem-se à amostra coletada mais próxima à soleira de basalto.

Castro et al. (2004) analisaram inclusões fluidas secundárias bifásicas aquosas contidas em grão de quartzo de rochas da Formação Irati em contato com as soleiras do Arco de Ponta Grossa. Estes autores encontraram temperaturas de homogeneização variando entre $190^{\circ}$ e $290^{\circ}$ para duas populações de inclusões, interpretadas como associadas à primeira fase de intrusão das soleiras, e entre $140^{\circ}$ e $170^{\circ} \mathrm{C}$ para a população de inclusões relacionada à segunda fase de intrusão das soleiras. Tendo como base as médias das temperaturas de homogeneização obtidas para as populações, os autores sugerem que a intrusão das soleiras pode ter proporcionado a formação de inclusões nas rochas da Formação Irati com temperaturas mínimas de $240^{\circ} \mathrm{C}$ e $155^{\circ} \mathrm{C}$, relacionadas à primeira e à segunda fase de intrusões das soleiras, respectivamente.

Para Castro et al. (2004), as temperaturas de homogeneização das inclusões aquosas seriam as temperaturas de aprisionamento e estariam relacionadas às temperaturas das rochas encaixantes alcançadas devido às intrusões das soleiras. Fuzikawa (1994 apud Araújo et al., 2000) sugere que as temperaturas medidas entre $60^{\circ}$ e $260^{\circ} \mathrm{C}$ indicam um vasto alcance das 
temperaturas de aprisionamento, e que possivelmente as temperaturas mais elevadas estariam relacionadas ao nível máximo de calor atingido pela Formação Irati devido a intrusão de soleiras de basalto, enquanto as temperaturas mais baixas, por sua vez, estariam associadas a um resfriamento que teria ocorrido durante a migração.

De acordo com o acima exposto, podemos concluir que os trabalhos anteriormente citados associam as temperaturas de aprisionamento das inclusões com aquelas relacionadas ao magmatismo Serra Geral. Desse modo, os fluidos aprisionados e as paleotemperaturas verificadas datariam da época da intrusão das soleiras associadas ao Serra Geral, e seriam contemporâneos à geração e à migração de hidrocarbonetos. Trata-se de uma hipótese possível, mas há uma segunda possibilidade para o aprisionamento dos paleofluidos da Formação Irati e para as paleotemperaturas registradas que será discutida a seguir.

Apesar das paleotemperaturas identificadas neste trabalho, a associação de inclusões bifásicas e monofásicas à temperatura ambiente e o fato de algumas inclusões monofásicas terem desenvolvido fase vapor durante as sucessivas etapas de resfriamento (o que sugere comportamento metaestável) são possíveis indicativos de que os paleofluidos da Formação Irati tenham sido aprisionados em temperaturas entre $50^{\circ}$ e $60^{\circ} \mathrm{C}$ (Goldstein \& Reynolds, 1994). Estas temperaturas são significativamente mais baixas que as temperaturas de homogeneização total adquiridas em laboratório, com picos entre $100^{\circ}$ e $150^{\circ} \mathrm{C}$ e que alcançam valores da ordem de $300^{\circ} \mathrm{C}$ (vide figuras 5.30A, 5.31A, 5.32A e 6.2) ou até mesmo superiores. As temperaturas de homogeneização total obtidas sugerem que as inclusões fluidas presentes na Formação Irati possam ter sido reequilibradas e, desse modo, não refletiriam as temperaturas de aprisionamento dos fluidos, mas as temperaturas relacionadas à evolução térmica da unidade após a cristalização dos veios de calcita e quarzto. Ou, essas temperaturas poderiam também estar relacionadas às intrusões das soleiras, uma vez que, de modo geral as inclusões primárias apresentam menores $\mathrm{TH}$, enquanto que durante o aprisionamento das pseudosecundárias e secundárias as TH aumentam. 


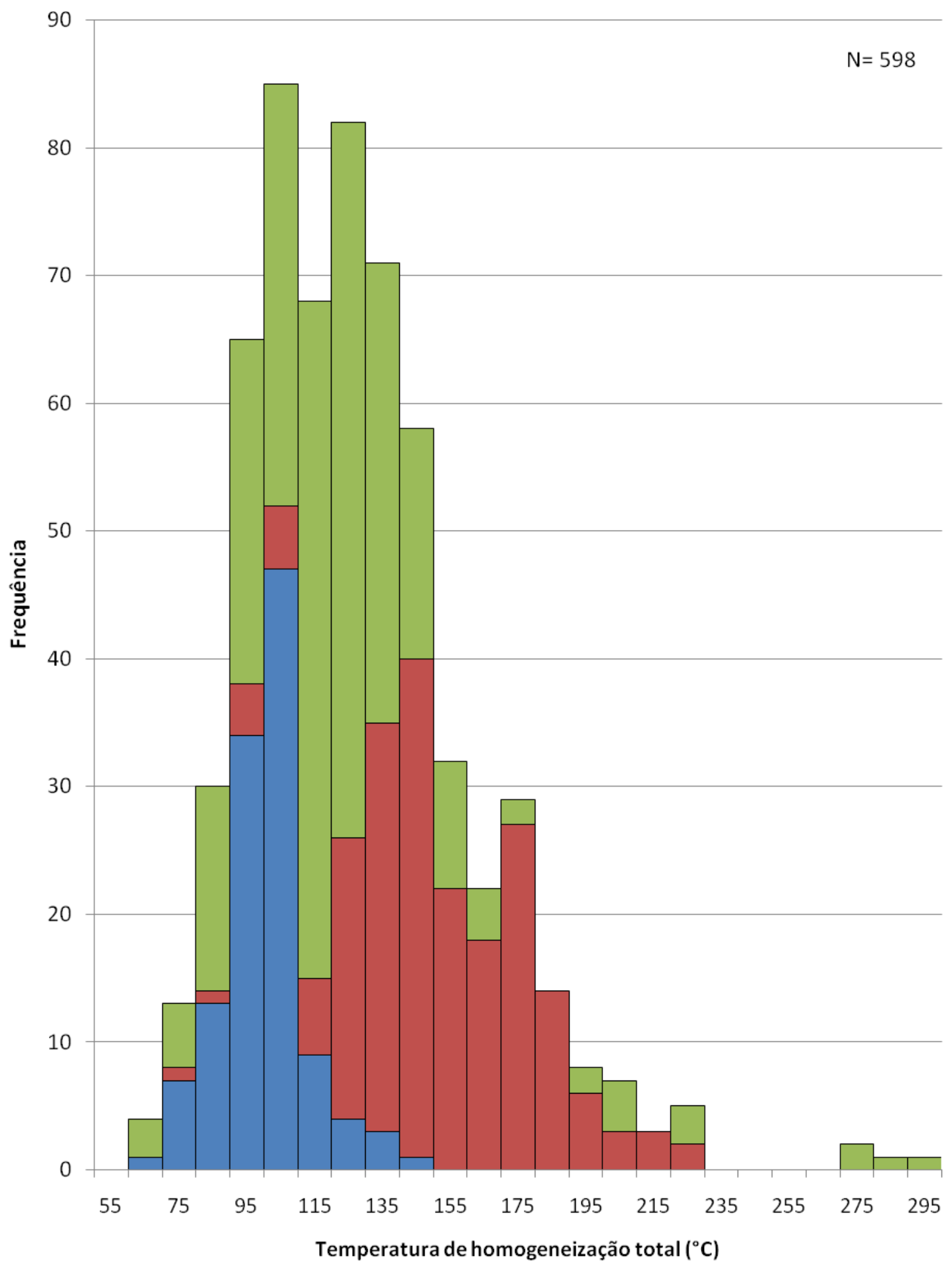

口Grupol $\quad$ Grupoll $\square$ GrupollI

Figura 6.2: Histograma de frequência de temperaturas de homogeneização total de inclusões fluidas hospedadas em veios de calcita espática (grupos I e II) e de quartzo (Grupo III) da Formação Irati. 
Para compreender melhor de que forma acontece o reequilíbrio, temos que levar em consideração que no ambiente sedimentar, durante o soterramento da unidade, as rochas, os minerais autigênicos e as inclusões fluidas aprisionadas nestes minerais são submetidos ao aumento de pressões e temperaturas decorrentes desse processo. No caso dos minerais autigênicos e rochas, as mudanças nas condições de pressão ocorrem dentro dos limites dados pelos gradientes hidrostático e litoestático. Contudo, no caso das inclusões fluidas, essas mudanças de pressão são condicionadas pela isócora representativa do volume molar ou densidade do fluido original. Quando o aumento da pressão é muito grande, pode ocorrer uma mudança irreversível no volume da inclusão fluida, uma vez que a pressão interna torna-se muito maior que a externa, o que resultará no surgimento da bolha ou aumento da bolha já existente ou no escape de fluidos, se existirem fissuras situadas próximas às bordas das inclusões. $\mathrm{O}$ aumento do volume das inclusões ocasiona um aumento no valor da temperatura de homogeneização medida (Larson et al., 1983; Prezbindowski \& Larese, 1987; Goldstein \& Reynolds, 1994) (Figura 6.3).

A expansão irreversível da inclusão através da sua deformação plástica causada pelas sobrepressões internas da própria inclusão fluida é denominada stretching. A temperatura de homogeneização total adquirida em laboratório corresponde à temperatura mínima do reequilíbrio por stretching (Prezbindowski \& Larese, 1987). Desse modo, é preciso ter em vista que as inclusões fluidas, os minerais hospedeiros e, portanto, as rochas foram submetidas a temperaturas mais altas que as registradas pelas inclusões fluidas (Goldstein \& Reynolds, 1994).

Algumas inclusões podem se reequilibrar rápida e repetidamente (mais de uma vez) ou não reequilibrarem. As variáveis que controlam o reequilíbrio são a resistência do cristal hospedeiro, a quantidade de sobreaquecimento (soterramento ou efeito de corpos ígneos), a pressão confinante na rocha, as propriedades de pressão, volume, temperatura e composição dos fluidos, o tamanho, a forma e a orientação das inclusões fluidas e sua posição relativa às descontinuidades do cristal. Em outras palavras, o reequilíbrio por stretching exerce um efeito diferente em cada uma das inclusões de uma assembleia de inclusões fluidas, o que causa uma variação significativa nas temperaturas de homogeneização. Essa ampla variação de temperatura de homogeneização pode representar um comportamento diagnóstico de que as inclusões fluidas daquele campo sofreram reequilíbrio (Prezbindowski \& Larese, 1987; Goldstein \& Reynolds, 1994). 
A ampla distribuição das temperaturas de homogeneização (Figura 6.2) é mais uma possível evidência de que as inclusões fluidas tenham sido submetidas a reequilíbrio por stretching, pois nos experimentos hidrotermais realizados por Prezbindowski \& Larese (1987) os autores verificaram uma ampliação da variação das temperaturas de homogeneização conforme as inclusões eram submetidas a temperaturas cada vez maiores durante a realização dos experimentos.

Além do reequilíbrio por stretching, outra forma de reequilíbrio térmico de inclusões pode ocorrer por troca de fluidos devido à entrada de novas soluções no sistema, as quais podem ter ou não a mesma composição das soluções originais.

Goldstein \& Reynolds (1994) apresentam um estudo de caso de inclusões fluidas primárias em que podem ser reconhecidas tendências de stretching e de troca de fluidos causados por reequilíbrio térmico. A Figura 6.4 apresenta um diagrama esquemático que teve como base os estudos de Goldstein \& Reynolds (1994). Nesta figura é representado o comportamento típico de inclusões reequilibradas por stretching, que apresentam diferentes temperaturas de homogeneização para fluidos com uma mesma salinidade, e por troca de fluidos, que exibem diferentes temperaturas de homogeneização para fluidos com salinidades distintas. Segundo estes autores, quando estão presentes as duas formas de reequilíbrio, o encontro das tendências, região compreendida pelo círculo, representa as condições originais dos fluidos aprisionados antes do reequilíbrio.

Para conhecer de que forma poderia ter ocorrido o reequilíbrio das inclusões fluidas, se por troca de fluidos e/ou por stretching, foram confeccionados gráficos de correlação entre as temperaturas de homogeneização total e temperaturas de fusão do gelo. Os gráficos de correlação dos grupos I e II (figuras 6.5A e 6.5B) demonstram que para um fluido de mesma salinidade há uma grande variação nas temperaturas de homogeneização, o que sugere que as inclusões fluidas presentes nesses grupos possam ter sido submetidas a reequilíbrio térmico por stretching. No gráfico de correlação referente ao Grupo III (Figura 6.6) observam-se dois comportamentos distintos; o primeiro reflete a ampla distribuição nos valores de temperatura de homogeneização para um fluido com salinidade mais baixa (stretching), enquanto, o segundo, exibe a menor distribuição nos valores de temperatura de homogeneização para um fluido com salinidade mais alta (bastante variável), sendo que ambos sugerem um possível reequilíbrio por stretching. Entretanto, nesse último caso poderia existir também a influência da troca de fluidos, já que a salinidade é muito variável. Observa-se um aumento da TH com a 
diminuição da salinidade. Talvez essas inclusões teriam sofrido reequilíbrio com a troca de fluidos sendo a temperatura já influenciada pelas soleiras de basalto.

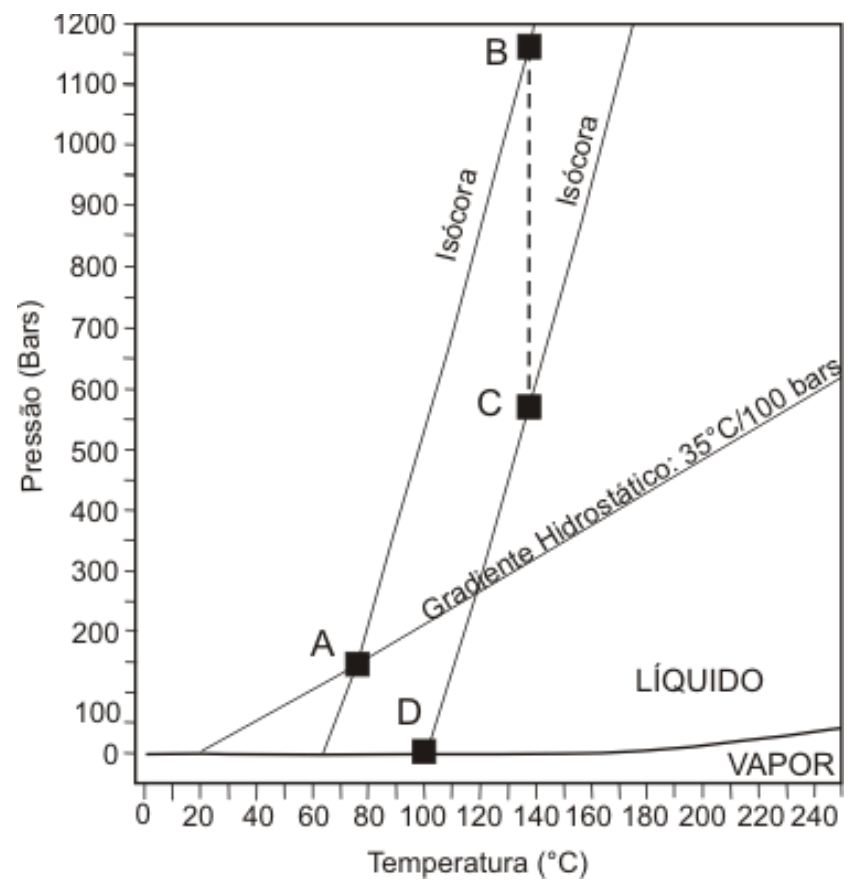

Figura 6.3: Diagrama pressão versus temperatura para o sistema $\mathrm{H}_{2} \mathrm{O}$. Se um fluido apriosinado no ponto $\mathrm{A}\left(75^{\circ} \mathrm{C}\right)$ for aquecido durante o soterramento, as pressões internas da inclusão irão seguir uma isócora em direção ao ponto $\mathrm{B}$ e sua pressão interna aumentará consideravelmente em comparação com a pressão hidrostática circundante. Se a inclusão sofrer estiramento devido a esta sobrepressão interna, seu volume aumentará enquanto a densidade e a pressão diminuirão. Este evento é representado por uma queda para o ponto $\mathrm{C}$, e leva a inclusão para uma nova isócora de menor densidade. Com o posterior resfriamento da inclusão essa isócora encontra a curva L-V (líquidovapor) no ponto $\mathrm{D}$ (numa temperatura de $100^{\circ} \mathrm{C}$ ) . Assim, a inclusão terá uma densidade que irá produzir a medição de temperatura de homogenização em $100^{\circ} \mathrm{C}$. Contudo, se a inclusão nunca tivesse sido reequilibrada por stretching, sua medição de temperatura de homogenização seria de $75^{\circ} \mathrm{C}$. Traduzido de Goldstein \& Reynolds (1994).

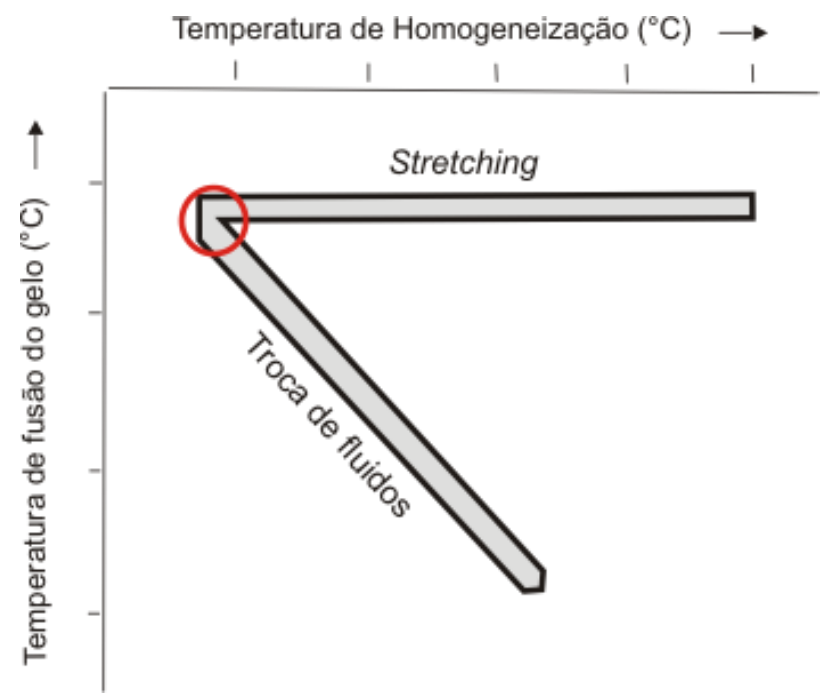

Figura 6.4: Diagrama esquemático ilustrando o comportamento de inclusões fluidas que foram submetidas a stretching e troca de fluidos, causados pelo reequilíbrio térmico. A região compreendida pelo círculo representa as condições originais dos fluidos aprisionados antes do reequilíbrio. Modificado de Goldstein \& Reynolds (1994). 

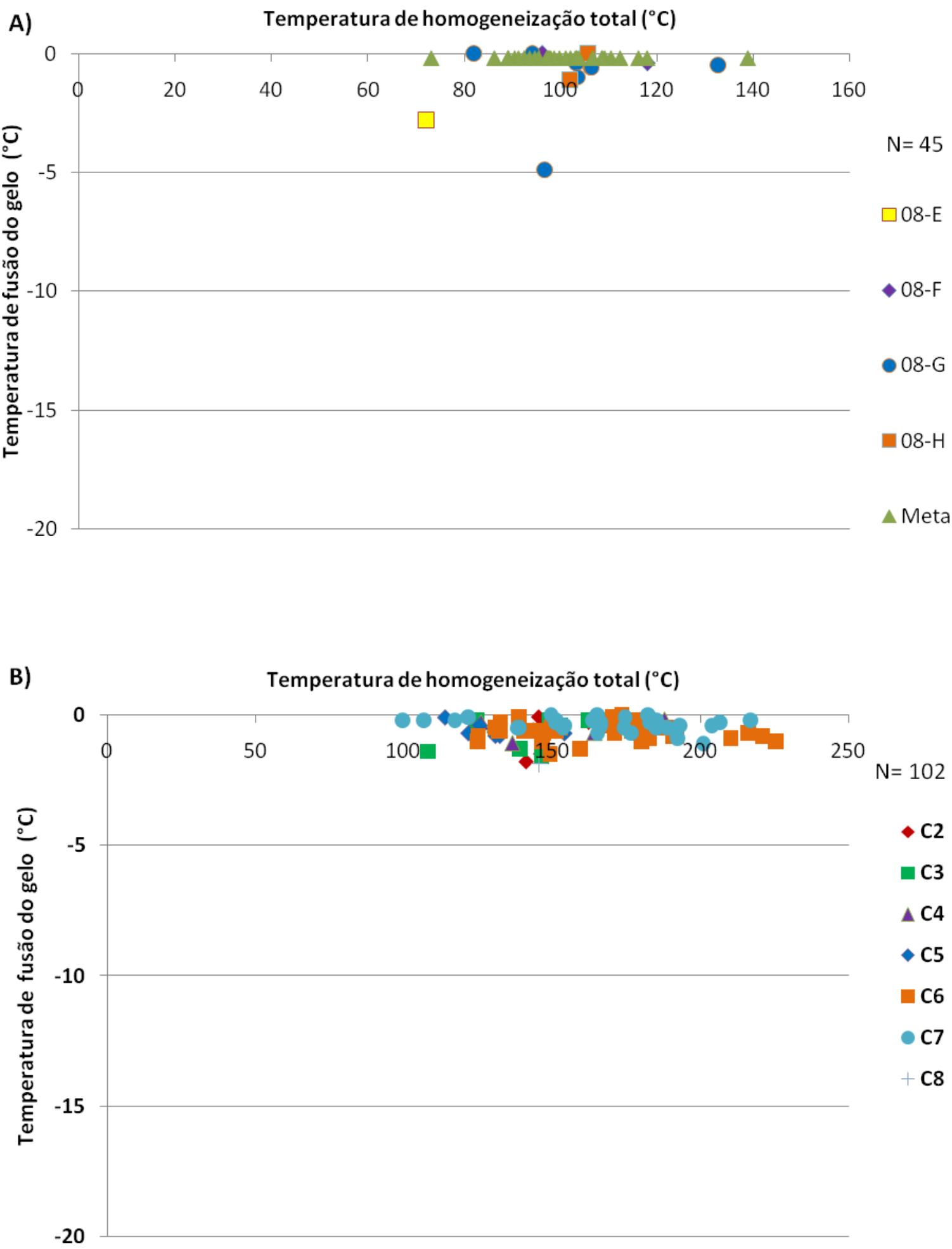

Figura 6.5: Gráficos de correlação das temperaturas de homogeneização total versus temperaturas de fusão do gelo para inclusões fluidas pertencentes ao: (A) Grupo I (hospedadas em veios de calcita espática na região de Cesário Lange -SP) e (B) Grupo II (contidas em veio de calcita espática nas proximidades de Paraisolândia -SP). 
Temperaturas de homogeneização total $\left({ }^{\circ} \mathrm{C}\right)$

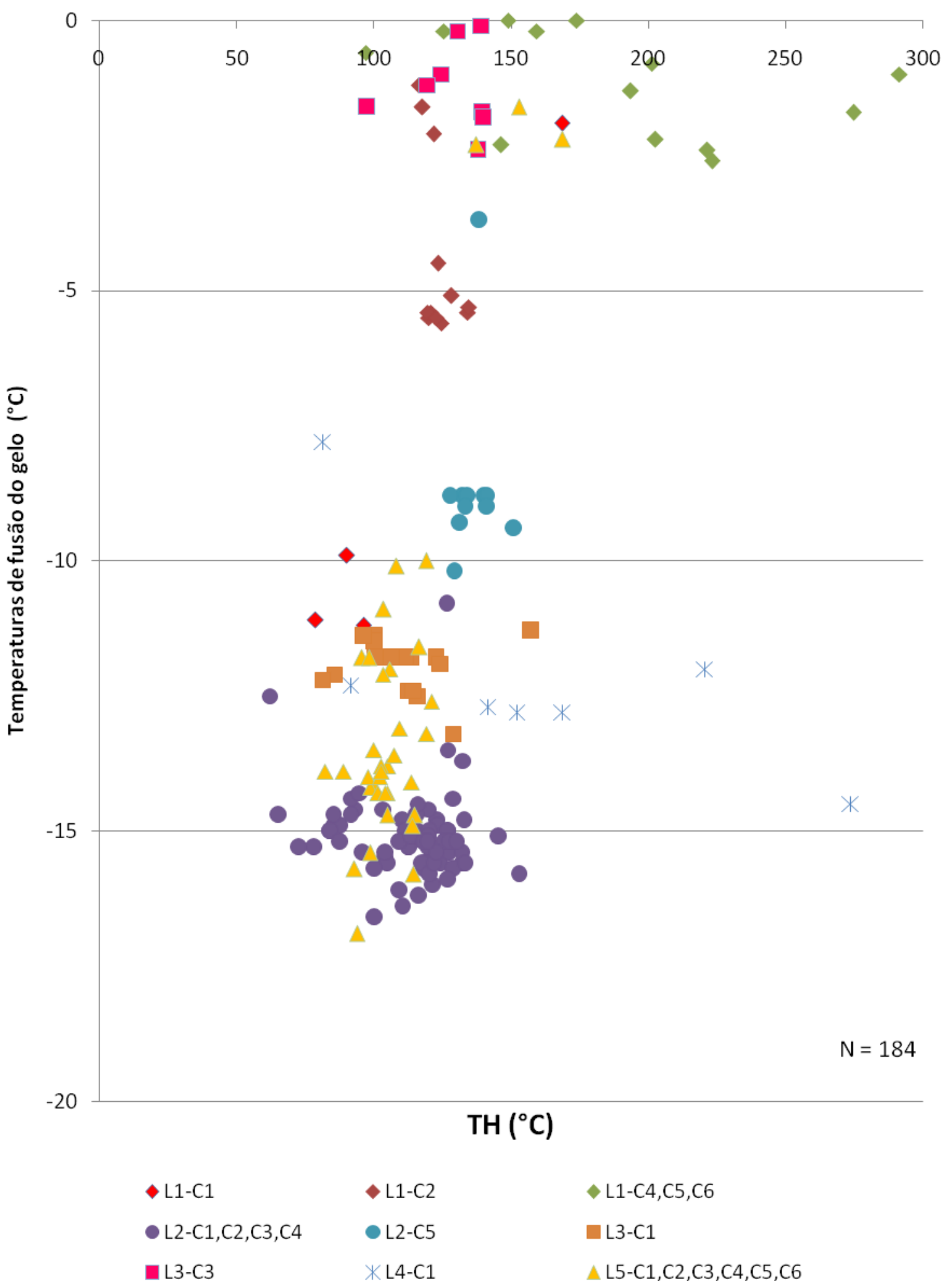

Figura 6.6: Gráfico de correlação das temperaturas de homogeneização total versus temperaturas de fusão do gelo para inclusões fluidas pertencentes ao Grupo III (hospedadas em veio de quartzo na região de Paraisolândia-SP). 


\subsection{Implicações para geração e migração de hidrocarbonetos}

A capacidade de geração de hidrocarbonetos por uma rocha depende da quantidade, qualidade (tipo) e evolução térmica da matéria orgânica. Os teores de carbono orgânico total encontrados para a Formação Irati sugerem que esta unidade apresenta um alto a excelente potencial de geração. Contudo, diversos autores afirmam que a unidade encontra-se imatura na maior parte da bacia, devido ao baixo soterramento, e só teria alcançado maturação nas áreas onde foram intrudidas por diques e soleiras associados ao magmatismo Serra Geral (Franzinelli, 1972; Araújo et al., 2000; Araújo, 2003; Araújo et al., 2004; Lisboa, 2006; Silva, 2007; França \& Porto Alegre, 2006; Souza et al., 2008; Thomaz-Filho et al., 2008).

As temperaturas de homogeneização de inclusões fluidas aquosas hospedadas em veios de calcita espática e quartzo da Formação Irati na área de estudo, situadas predominantemente no intervalo entre 60 e $230^{\circ} \mathrm{C}$, revelaram que a unidade atingiu temperaturas suficientes para a geração e óleo, cuja janela de geração está geralmente situada entre $60^{\circ}$ e $120^{\circ} \mathrm{C}$ (com picos de geração em $90^{\circ} \mathrm{C}$ ), e de gás, que possui janela de geração entre $120^{\circ}$ e $150^{\circ} \mathrm{C}$ (Hunt, 1995).

As altas temperaturas alcançadas pela Formação Irati na área de estudo, não podem ser explicadas apenas pelo soterramento da unidade, cuja profundidade máxima estimada para a borda leste da bacia é cerca de 1500 metros (Zalán et al., 1991). Assim, as paleotemperaturas interpretadas necessitam de uma fonte adicional de calor, possivelmente proveniente do magmatismo Serra Geral.

A presença de inclusões fluidas de hidrocarbonetos hospedadas em minerais de preenchimento de fratura é mais uma evidência dos processos de geração e migração de hidrocarbonetos. De acordo com Munz (2001) a cor de fluorescência de inclusões de hidrocarbonetos fornece informações sobre sua composição e maturidade. Além disso, a relação entre as fases líquida e vapor à temperatura ambiente é função da composição e da densidade do hidrocarboneto. Goldstein \& Reynolds (1994) mencionam que a cor de fluorescência pode ser correlacionada com o Grau API; entretanto, salientam que essa correlação serve apenas para efeito de comparação, pois há múltiplas variáveis que podem controlar a cor de fluorescência. Segundo Munz (2001), inclusões compostas por gás condensado exibem grandes bolhas de fase vapor à temperatura ambiente, enquanto, inclusões compostas por óleo volátil ou black oil apresentam fase líquida dominante e fase vapor subordinada. 
De acordo com Munz (2001) inclusões fluidas com fase vapor relativamente pequena, incolor e com fluorescência azulada pálida, sugerem composição de óleo volátil relativamente maduro. Por sua vez, inclusões com fase vapor predominante sobre a fase líquida e cor azul escura de fluorescência indicam que o fluido é um condensado.

As inclusões fluidas de hidrocarboneto contidas em veios de calcita espática pertencentes ao Grupo I, geralmente exibiram grandes bolhas de fase vapor de coloração escura, e cores de fluorescência de amarelada a azul pálida. Tendo como base as informações apresentadas por Munz (2001), pode-se interpretar que essas inclusões sejam compostas por um condensado.

No veio de calcita espática referente ao Grupo II, hospedam-se as inclusões fluidas de hidrocarbonetos com pequena proporção da fase vapor, incolor, e cor de fluorescência azulada pálida, sugerindo trata-se de inclusões compostas por óleo volátil ou black oil relativamente maduro. A cor de fluorescência quando comparada com o Grau API sugere Grau API entre $40^{\circ}$ e $45^{\circ}$. Ainda que essa correlação seja apenas para efeitos comparativos, e esteja sujeita a fontes de erros associada a outros fatores que controlam a cor de fluorescência de uma inclusão, podemos interpretar que se trata de um óleo leve (> 31.1 - Classificação de Hunt, 1995) de excelente qualidade.

As inclusões fluidas de hidrocarbonetos contidas em veio de quartzo correspondentes ao Grupo III exibiram duas formas de ocorrências distintas. Na primeira, predominante, as inclusões apresentaram grande bolhas de fase vapor, de cor escura e cor de fluorescência azul pálida a azul. Na segunda, as inclusões exibiram bolhas de fase vapor pequenas a médias, de cor escura, e cor de fluorescência azul pálida a azul. Para a primeira ocorrência, interpreta-se que os fluidos correspondam a um condensado, enquanto, a segunda forma de ocorrência pode estar relacionada à composição de óleo volátil relativamente maturo. Correlacionando a cor de fluorescência com o Grau API, podemos supor que se trata de um óleo leve (Grau API $>31.1^{\circ}$ ) de excelente qualidade.

Mesmo com a necessária cautela no momento de interpretar a composição, a maturidade e o Grau API das inclusões de hidrocarboneto inferidos por meio das observações petrográficas com luz ultravioleta, pode-se concluir que os hidrocarbonetos aprisionados revelam que os óleos gerados pela Formação Irati, nas suas características pretéritas, poderiam corresponder a óleo leves e maturos, diferentemente dos óleos extra-pesados (grau API < 10) observados em afloramentos da unidade geradora e dos arenitos asfálticos da Formação Pirambóia. Além disso, segundo a literatura foi recuperado óleo com Grau API de 
22 a $33^{\circ}$ na Formação Rio Bonito em poços perfurados no domínio sul da bacia (Milani et al., 2007a). Excluindo-se a possibilidade que a origem destes óleos extra-pesados seja relacionada à baixa maturidade, a hipótese da biodegradação torna-se mais plausível. A biodegradação possivelmente teria ocorrido durante os processos de migração e acumulação ou durante a exumação.

Os fluidos aquosos de salinidades mais baixas, encontrados nas inclusões hospedadas em veios de calcita pertencentes ao grupos I e II e em algumas inclusões contidas em veio de quartzo (Grupo III) juntamente com o trabalho de Castro et al. (2004), que encontraram salinidades variando entre 0,7 e 3,06 \% em peso de $\mathrm{NaCl}$ equivalente para inclusões secundárias em grão de quartzo, possivelmente, estão relacionados a percolação de água meteórica. Caso a circulação de fluidos meteóricos ocorresse em fraturas subverticais de forma concomitante a geração e início da migração, isso seria altamente prejudicial à preservação dos hidrocarbonetos causando sua biodegradação.

Para Hunt (1995) a biodegradação é um processo natural no qual microorganismos presentes nas águas meteóricas podem degradar os compostos orgânicos contidos no petróleo. A biodegradação ocasiona alterações moleculares nos compostos orgânicos do petróleo e resulta no aumento do teor de enxofre, da acidez do óleo, da viscosidade, do conteúdo de metais, e no decréscimo da qualidade do óleo (Grau API). Esse processo pode ocorrer tanto sob condições anaeróbicas quanto aeróbicas, sendo mais comumente encontrado no ambiente aeróbico.

A geração, migração e acumulação de hidrocarbonetos do sistema petrolífero IratiPirambóia teria ocorrido concomitantemente dentro de um curto espaço de tempo ( 10 Ma) (Thomaz-Filho,1982; Araújo et al., 2000; Araújo et al., 2004, 2006). Contudo, esse intervalo de tempo pode ser ainda menor se considerado um trabalho mais recente sobre a duração do magmatismo. Segundo Thiede \& Vasconcelos (2010), o magmatismo Serra Geral pode ter durado apenas 1 Ma. Desse modo, tratar-se-ia de um sistema com geração e migração episódica.

Nos afloramentos selecionados para estudo de inclusões fluidas, nos quais as fraturas preenchidas por betume e a existência de inclusões de hidrocarbonetos nos veios diagenéticos comprovam a atuação dos processos de geração e migração, os dois principais sistemas de fraturas (NE-SW e NW-SE) indicariam campos de esforços distintos. As fraturas NE-SW com pequena continuidade vertical, possivelmente, permitiriam apenas a migração de hidrocarbonetos dentro dos limites da Formação Irati enquanto que as fraturas NW-SE, de 
continuidade vertical métrica, eventualmente, seriam responsáveis pela migração dos hidrocarbonetos para outras unidades. Essa interpretação está de acordo com a proposta de Thomaz Filho (1982), Zalán et al. (1991), Araújo et al. (2004) e Strugale et al. (2007) entre outros, que afirmam que os caminhos de migração principal estariam relacionados com estruturas de direção NW e consideram que esse padrão esteja associado ao Arco de Ponta Grossa, principalmente às reativações ao longo do alinhamento Guapiara. A origem do padrão NE, por sua vez, estaria relacionada às zonas de fraqueza do embasamento (Zalán et al., 1990b). 


\section{CONCLUSÕES}

- As concentrações de carbono orgânico (COT) dos folhelhos da Formação Irati nos afloramentos estudados nos estados de São Paulo e do Paraná permitiram a avaliação do potencial de geração da unidade como alto a excelente, exceto na localidade onde os folhelhos foram afetados pela intrusão de uma soleira de basalto, que devido ao craqueamento térmico apresenta baixo COT devido a geração de hidrocarbonetos.

- Os baixos teores de carbono orgânico total (COT) encontrados para as formações Serra Alta e Corumbataí revelam baixo potencial gerador para essas unidades na localidade de estudo.

- As concentrações de enxofre aparentemente possuem controle deposicional e em alguns afloramentos é possível observar certa correlação entre os teores de carbono orgânico total e enxofre.

- A caracterização petrográfica das rochas carbonáticas seccionadas por veios de quartzo e de calcita espática permitiu a classificação dessas rochas como um mudstone.

- Os paleofluidos aquosos aprisionados nas inclusões contidas em veios de calcita espática e de quartzo exibem a mesma composição, $\mathrm{H}_{2} \mathrm{O}+\mathrm{NaCl}+\mathrm{CaCl}_{2}$, mas salinidades distintas, 0,23 e 7,27\% em peso de $\mathrm{NaCl}$ equivalente (Grupo I), 0 a 3,26\% em peso de $\mathrm{NaCl}$ equivalente (Grupo II) e 0 a 21,67\% em peso de $\mathrm{NaCl}$ equivalente (Grupo III).

- As paleotemperaturas medidas em inclusões aquosas estão situadas predominantemente entre $60^{\circ}$ e $230^{\circ} \mathrm{C}$. Existem duas hipóteses para explicar essas temperaturas de homogeneização: (i) estas corresponderiam às temperaturas de aprisionamento dos fluidos e estariam relacionadas às intrusões do magmatismo Serra Geral; (ii) tratar-se-iam de temperaturas de reequilíbrio por stretching 
(predominantemente) e por troca de fluidos, associadas ao soterramento e ao magmatismo Serra Geral.

- Independente do momento em que aconteceu o aprisionamento dos fluidos aquosos ou se as inclusões fluidas foram reequilibradas ou não, a informação mais relevante é a de a que a Formação Irati atingiu temperaturas suficientes para geração de óleo e gás $\left(60^{\circ}\right.$ e $\left.150^{\circ} \mathrm{C}\right)$.

- As paleotemperaturas encontradas para a Formação Irati na área de estudo, situada na borda leste da Bacia do Paraná, não podem ser explicadas apenas pelo soterramento da unidade, estimado em 1500 metros para esta região, necessitando de uma fonte adicional de calor que provavelmente foi fornecida pelo magmatismo Serra Geral.

- A presença de inclusões fluidas de hidrocarbonetos nos veios de calcita espática e de quartzo confirma os processo de geração e a migração de hidrocarbonetos a partir da unidade geradora Irati.

- As inclusões de hidrocarboneto revelaram óleo relativamente maturo e leve sugerindo que o óleo com alta viscosidade e baixo Grau API encontrado nos afloramentos da unidade geradora Irati e nos reservatórios arenosos da Formação Pirambóia (arenitos asfálticos) é produto de degradação. Essa afirmação também é embasada pelo fato de ter sido encontrado óleo de coloração marrom claro com viscosidade moderada preenchendo fraturas milimétricas restritas à camada de rocha carbonática; possivelmente, esse óleo foi mais bem preservado dos efeitos prejudiciais da degradação. Além disso, segundo a literatura foi recuperado óleo com Grau API de 22 a $33^{\circ}$ na Formação Rio Bonito em poços perfurados no domínio sul da bacia.

- Fluidos aquosos de menor salinidade (encontrados em todos os grupos de inclusões fluidas analisadas) possivelmente compostos por água meteórica, que eventualmente circulassem por fraturas subverticais durante a geração e a migração do petróleo, seriam altamente prejudiciais para a preservação dos hidrocarbonetos, ocasionando sua degradação. 


\section{REFERÊNCIAS BIBLIOGRÁFICAS}

Allen, P.A.; Allen, J.R. 2005. Basin analysis: principles and applications. Blackwell Pub. 549p.

Araújo-Barberena, D.C. 1993. Uma interpretação sobre o conhecimento paleoecológico e bioestratigráfico da Formação Irati. In: Simpósio Sobre Cronoestratigrafia da Bacia do Paraná, 1, 1993. Rio Claro. Resumos... Rio Claro: IG-UNESP, p.64-70.

Araújo, C. C. Gênese das ocorrências de arenito asfáltico da borda leste da Bacia do Paraná, SP. 2003. Tese (Doutorado) - Instituto de Geociências, Universidade de São Paulo, São Paulo.

Araújo, L. M.; Trigüis, J. A.; Cerqueira, J. R.; Freitas, L. C. S. 2000. The atypical Permian petroleum system of the Paraná Basin, Brasil. In: Mello, M. R.; Katz, B. J. Petroleum systems of South Atlantic margin. AAPG Memoir: v.73, p.377-402.

Araújo, C. C.; Yamamoto, J. K.; Rostirolla, S. P. 2004. Distribuição espacial e caracterização geológica dos arenitos asfálticos das borda leste da Bacia do Paraná no estado de São Paulo. Revista Brasileira de Geociências, São Paulo, v. 34, n. 2, p. 187-200.

Araújo, C. C.; Yamamoto, J. K.; Rostirolla, S.P. 2006. Arenitos asfálticos na Bacia do Paraná: estudos das ocorrências no Alto Estrutural de Anhembi. B. Geoci. Petrobras, Rio de Janeiro, v.14, n.1, p 4770 .

Bakker, R.J. 2003. Package Fluids 1. Computer programs for analysis of fluid inclusion data and for modeling bulk fluid properties. Chemical Geology, 194, p.3-23.

Barbosa, O; Almeida, F.F.M. 1948. Nota sobre a estratigrafia da Série Tubarão no Estado de São Paulo. Anais da Academia Brasileira de Ciências. Rio de Janeiro, v. 21, n.1, p.65-68.

Barbosa, O.; Gomes, F.A. 1958. Pesquisa de petróleo na bacia do rio Cormbataí, Estado de São Paulo. Boletim da Divisão de Geologia e Mineralogia do DNPM, Rio de Janeiro, v.71, p.1-40.

Castro, A. B.; Mesquita, M. J.; Vasconcellos, E. M. G. 2004. Análise de inclusões fluidas em rochas sedimentares da Formação Irati da Bacia do Paraná (BR) no contato com sills do Arco de Ponta Grossa. In: $42^{\circ}$ Congresso Brasileiro de Geologia, Araxá. Anais... Araxá.

Cerqueira, J. R.; Santos Neto, E. V. 1990. Caracterização geoquímica das rochas geradoras de petróleo da Formação Irati e dos óleos a ela relacionados, Bacia do Paraná, Brasil. In: II Congresso Latinoamericano de Geoquímica Orgânica, 1990. Caracas. Anais... Caracas: v.1, p.26.

Coelho, C. E. S. O. 2005. Estudo de inclusões fluidas na exploração de petróleo. Boletim de Geociências da Petrobras, Rio de Janeiro, v.13, n.1, p.61-80.

Crawford, M.L.; Hollister, L.S. 1992. Fluid-rock interactions during Metamorfhism. In: Walter, J. V.; Wood, B.J. (Eds.) Advances in Physical Chemistry, v. 4., p. 1-35. 
Daemon, R.F.; Quadros, L.P. 1970. Bioestratigrafia do Neopaleozóico da Bacia do Paraná. In: Congresso Brasileiro De Geologia, 24, Brasília. Anais..., Brasília: SBG, p. 359-412.

Davis, D.W.; Lowenstein, T.K.; Spencer, R.J. 1990. Melting behavior of fluid inclusion in laboratory -grow halite crytals in the systems $\mathrm{NaCl}-\mathrm{H}_{2} \mathrm{O}, \mathrm{NaCl}-\mathrm{KCl}-\mathrm{H}_{2} \mathrm{O}, \mathrm{NaCl}-\mathrm{MgCl}_{2}-\mathrm{H}_{2} \mathrm{O}$, and $\mathrm{NaCl}-\mathrm{CaCl}_{2}-$ $\mathrm{H}_{2} \mathrm{O}$. Geochimica et Cosmochimica Acta, v. 54, p. 591-601.

Demaison, G.; Huizinga, B.J. 1994. Genetic classification of petroleum systems using three factors: charge, migration and entrapment. AAPG Memoir, n.60, p. 73-89.

Fairchild, T.R.; Coimbra, A.M.; Boggiani, P.C. 1985. Ocorrência de estromatólitos silicificados na Formação Irati (Permiano) da borda setentrional da Bacia do Paraná. Anais da Academia Brasileira de Ciências, Rio de Janeiro. v.57 n.1 p.17.

Ferrill, D. A.; Morris, A.P.; Evans, M.A.; Burkhard, M.; Groshong, R.H.; Onasch, C.M. 2004. Calcite twin morphology: a low-temperature deformation geothermometer. Journal of Structural Geology, 26(8), 1521-1529.

França, B. A,; Porto Alegre, H. K. 2006. Petróleo não convencional na usina de São Mateus do Sul. In: $44^{\circ}$ Congresso Brasileiro de Geologia, Aracajú. Anais... Aracajú.

Franzinelli, E. Arenitos asfálticos do Estado de São Paulo. 1972. Tese (Doutorado) - Instituto de Geociências, São Paulo.

Fuzikawa, K. 1985. Inclusões fluidas: métodos usuais de estudo e aplicações. Contribuições à geologia e à petrologia. SBGM, p.29-44.

Goldstein,R.H. 2001.Fluid inclusions in sedimentary and diagenetic systems. Lithos 55, 159-192.

Goldstein, R. H.; Reynolds, T. J. 1994. Systematic of fluid inclusions in diagenetic minerals. Society for Sedimentary Geology Short Course, 31, Tulsa, Society of Sedimentary Geology, 199p.

Hachiro, J. 1991. Litotipos, associações faciológicas e sistemas deposicionais da Formação Irati no Estado de São Paulo. Dissertação (Mestrado) - Instituto de Geociências, São Paulo.

Hachiro, J. 1997. O subgrupo Irati (Neopermiano) da Bacia do Paraná. 1996. Tese (Doutorado) Instituto de Geociências, São Paulo.

Hachiro, J. 2000. Occurrences of evaporites in the Irati Sub-Group (Late Permian, Paraná Basin). Anais da Academia Brasileira de Ciências, 72(4), 600.

Hachiro, J. Coimbra, A.M. 1991. Sucessões sedimentares e ciclos transgressivo-regressivos da Formação Irati no Estado de São Paulo. In: Simpósio de Geologia do Sudeste, 2., São Paulo, Atas... São Paulo: SBG. p.45-62.

Hachiro, J.; Coimbra, A.M.; Matos, S.L.F. O. 1993. Caráter cronoestratigráfico da Unidade Irati. In: Simpósio sobre Cronoestratigrafia da Bacia Do Paraná, Rio Claro. Resumos..., Rio Claro: IG-UNESP, p.62-63.

Horsfield, B.; Rullkotter, J. 1994. Diagenesis, Catagenesis, and Metagenesis of Organic Matter: Chapter 10: Part III. Processes. AAPG Special Volumes. Volume M 60: The Petroleum System--From Source to Trap, p 189 - 199. 
Hunt, J. M. 1995. Petroleum Geochemistry and Geology. Second Edition. Editora Freeman.

Jones, S.F.; Wielens, H.; Williamson, M-C., Zentilli, M. 2007. Impact of magmatism on petroleum systems in the sverdrup basin, Candian artic islands, Nunavut: a numerical modelling study. Journal of Petroleum Geology, 30(3):219-236.

Larson, L.T.; Miller, J.D.; Nadeau, J.E.; Roedder, E. 1973.Two sources of error in low temperature inclusion homogenization determination, and corrections on published temperatures for the east Tennessee and Laisvall deposit. Economic Geology, v. 68, p. 113-116.

Lisboa, A. C. 2006. Caracterização geoquímica dos folhelhos neopermianos da Formação Irati Borda leste da Bacia do Paraná. Dissertação (Mestrado) - Universidade Federal do Rio de Janeiro, Rio de Janeiro.

Maranhão, M.S.A.S. 1997. Reconstituição paleoambiental das sequências do Permiano Superior da Bacia do Paraná no Estado de São Paulo. In: Simpósio Sobre Cronoestratigrafia da Bacia do Paraná, 3., Barra do Garça. Resumos...Barra do Garça: UFRJ. p.27-29.

Milani, E. J. 1997. Evolução tectono-estratigráfica da Bacia do Paraná e seu relacionamento com a geodinâmica estratigráfica fanerozóica do Gondwana Sul-Ocidental. Tese (Doutorado) - Instituto de Geociências, Rio Grande do Sul.

Milani, E.J.; Ramos, V.A. 1998. Orogenias paleozóicas no domínio sul-ociental do Gondwana e os ciclos de subsidência da Bacia do Paraná. Revista Brasileira de Geociências. v.28. n.4, p. 473-484.

Milani, E.J.; Zalan, P.Y. 1999. An outline of the geology and petroleum systems of the Paleozoic interior basins of South America. Episodes, 22(3), 199-205.

Milani, E. J.; França, A. B.; Schneider, R. L. 1994. Bacia do Paraná. Boletim de Geociências Petrobras, Rio de Janeiro, v.8, n.1, p.69-82.

Milani, E.; Araújo, L.M. 2003. Recursos Minerais Energéticos: Petróleo. In: Bizzi, L.A.; Schobbenhaus, C.; Vidotti, R.M.; Gonçalves, J.H. (Eds). Geologia, Tectônica e Recursos Minerais do Brasil. Brasília: CPRM, p. 541-576.

Milani, E.J.; França, A.B.; Medeiros, R.A., 2007a. Rochas geradoras e rochas reservatório da Bacia do Paraná, faixa oriental de afloramentos, Estado do Paraná. In: Bacia do Paraná. Boletim de Geociências Petrobras. Petrobras, Rio de Janeiro, v.15, n.1, p.135-162.

Milani, E. J.; Brandão, J.A.S.L.; Zalán, P.V.; Gamboa, L.A.P. 2000. Petróleo na margem continental brasileira: Geologia, exploração, resultados e perspectivas. Brasilian Journal of Geophysic, v. 18, n.3, p. 351-396.

Milani, E. J.; Melo, J. H.G.; Souza, P.A.; Fernandes, L. A.; França, A. B. 2007b. Bacia do Paraná. Boletim de Geociências Petrobras, Rio de Janeiro, v.15, n.2, p. 265-287.

Munz, I. A. 2001. Petroleum inclusions in sedimentary basins: systematics, analytical methods and applications. Lithos, 55:195-212.

Orr, W. L. 1986. Kerogen/asphastene/súlfur relatioships in súlfur-rich Monterey oils. Org.Geochem. Vol. 10, p.419-516. 
Perrotta, M.M.; Salvador, E.D.; Lopes, R.C.; D'Agostino, L.Z.; Wildner, W.; Ramgrab, G. E.; Peruffo, N.; Freitas, M.A.; Gomes, S.D.; Chieregati, L. A.; Silva, L.C.; Sachs, L.L.B.; Silva, V.A.; Batista, I.H.; Marcondes, P.E.P. 2004. Folha Curitiba SG-22. In: Schobbenhaus, C.; Gonçalves, J.H.; Santos, J.O.S.; Abram, M.B.; Leão Neto, R.; Matos, G.M.M., Vidotti, R.M., Ramos, M.A.B., Jesus, J.D.A. de. (eds.). Carta Geológica do Brasil ao Milionésimo, Sistema de Informações Geográficas. Programa Geologia do Brasil. CPRM, Brasília. CD-ROM.

Perrotta, M.M.; Salvador, E.D.; Lopes, R.C.; D'Agostino, L.Z.; Peruffo, N.; Freitas, M.A.; Gomes, S.D.; Sachs, L.L.B.; Meira, V.T.; Garcia, M.G.M.; Lacerca Filho, J.V. 2005. Mapa Geológico do Estado de São Paulo, escala 1:750.000. Programa Geologia do Brasil. CPRM, São Paulo.

Peters, K.E.; Cassa, M.R. 1994. Applied Source Rock Geochemistry. AAPG Memoir n.60, p. 93-120

Prezbindowski, D. R.; Larese, R. E. 1987. Experimental stretching of fluid inclusions in calcite Implications for diagenetic studies. Geology, v. 15 p. 333-336.

Roedder, E., 1977. Fluid inclusions as tools in mineral exploration. Economic Geology. v.72, p.503525 .

Roedder, E., 1982. Fluid inclusions in gemstones: valuable defects. In: International Gemological Symposium, Santa Monica, Proceedings, Santa Monica, Geomological Institute of America, p.479502.

Roedder, E. 1984. Fluid inclusions. In: RIBBE, P. H. Reviews in mineralogy. Mineralogy Society of America, v.12, 646p.

Roedder, E., Skinner, B.J. 1968. Experimental evidence that fluid inclusions do not leak. Economic Geology. v.63, p.715-730.

Ricardi-Branco, F.; Caires, E.T.; Silva, A.M. 2008. Levantamento de ocorrências fósseis nas pedreiras de calcário do Subgrupo Irati no estado de São Paulo, Brasil. Revista Brasileira de Geociências v.38, n.1. p. $78-86$.

Santos, R.V.; Souza, P.A.; Alvarenga, C.J.S.; Dantas, E.L.; Pimentel,M.M.; Oliveira, C.G.; Araújo, L.M. 2006. Shirimp U-Pb Zircon dating and palinology of bentonitic layers from the Permian Irati Formation, Paraná Basin, Brazil. Gondwana Research, Osaka, v.9. p.456-463.

Schneider, R. L.; Muhlmannn, H.; Tommasi, E.; Medeiros, R. A.; Daemon, R. F., Nogueira, A. A. 1974. Revisão Estratigráfica da Bacia do Paraná. In: Congresso Brasileiro De Geologia, 28., Porto Alegre. Anais do...São Paulo: SBG, 1974. v.1. p.41-65.

Sheperd, T. J.; Rankin, A. H.; Alderton, D. H. 1985. A pratical guide do fluid inclusions studies. Blackie and Son Ltd, New York, 239p.

Silva, C. G. A. 2007. Caracterização geoquímica orgânica das rochas geradoras de petróleo das formações Irati e Ponta Grossa da Bacia do Paraná. Dissertação (Mestrado) - Universidade Federal do Rio Grande do Sul, Porto Alegre.

Silva, A.J.P.; Lopes, R.C.; Vasconcelos, A.M.; Bahia, R.B.C. 2003. Bacias Sedimantares Paleozóicas e Meso-Cenozóicas Interiores. In: Bizzi, L.A.; Shobbennhaus; Vidotti, R.M.; Gonçalves, J.H. Geologia, tectônica e recursos minerais do Brasil. Serviço Geológico do Brasil - CPRM., 674p. 
Souza, I. V. A. F.; Mendonça-Filho, J. G.; Menezes, T. R. 2008. Avaliação do efeito térmico das intrusivas ígneas em um horizonte potencialmente gerador da Bacia do Paraná: Formação Irati. Revista Brasileira de Geociências, v. 38, n.2 (suplemento), p.138-148.

Strugale; Rostirolla, S. P.; Mancini, F.; Portela Filho C. V.; Ferreira F.J.F.; Freitas, R. C. 2007. Structural framework and Mesozoic-Cenozoic evolution of Ponta Grossa Arch, Parana' Basin, southern Brazil. Journal of South American Earth Sciences, 24, 203-227.

Thiede, D.S., Vasconcelos, P.M. 2010. Paraná flood basalts: Rapid extrusion hypothesis confirmed by new ${ }^{40} \mathrm{Ar} /{ }^{39} \mathrm{Ar}$ results. Geology, 38(8), 747-750.

Thomaz Filho, A. 1982. Ocorrência de arenito betuminoso em Anhembi (SP) - cubagem e condicionamento geológico. In: Congresso Brasileiro de Geologia, 32., 1982, Salvador. Anais... São Paulo: Sociedade Brasileira de Geologia, v. 5, p. 2344-2348.

Thomaz Filho, A.; Cordani, U.G.; Kawashita, K. 1976. Aplicação do método Rb-Sr na datação de rochas sedimentares argilosas da Bacia do Paraná. In: Congresso Brasileiro de Geologia, 29, 1976. Ouro Preto. Anais do...Ouro Preto: SBGeologia, v.1. p.289-302.

Thomaz Filho, A.T.; Mizusaki, A. M. P.; Antonioli, L. 2008. Magmatismo nas bacias sedimentares brasileiras e sua influência na geologia do petróleo. Revista Brasileira de Geociências, v. 38, n.2(suplemento), p.128-137.

Weisbrod, A.; Poty, B.; Touret, J. 1976. Les inclusions fluides en géochimie-pétrologie: tendances actuelles. Bull. Soc. Fr.Minéral. Cristallog., 99:140-152.

White, I.C. 1908. Relatório sobre as coal measures e rochas associadas ao sul do Brasil. Rio de Janeiro: Comissão das Minas de Carvão de Pedra do Brasil, 300p.

Zalán, P. V.; Wolff, S.; Conceição, J. C. J.; Marques, A.; Astolfi, M. A. M.; Vieira, I. S.; Appi, V. T.; Zanotto, O.A. 1990a. Bacia do Paraná. In: Gabaglia, G.P.R.; Milani, E.J. Origem e evolução de bacias sedimentares. $2^{\mathrm{a}}$ edição. Rio de Janeiro. PETROBRAS, p.135-168.

Zalán, P. V.; Wolff, S. ; Astolfi, M. A. M.; Vieira, I. S.; Conceição, J. C. J.; Appi, V. T.; Santos Neto, E. V.; Cerqueira, J. R.; Marques, A. 1990b. The Paraná Basin, Brasil. In: LEIGHTON, M. W.; KOLATA, D. R.; OLTZ, D. F.; EIDEL, J. J. Interior cratonic basins.Tulsa: American Association of Petroleum Geologists, (AAPG. Memoir, 51), p. 681-708.

Zalán, P. V.; Wolff, S.; Conceição, J. C. J.; Astolfi, M. A. M.; Vieira, I. S.; Appi, V. T.; Zanotto, O.A.; Marques, A. 1991. Tectonics and sedimentation of the Paraná Basin. In: Ulbrich, H.; Rocha Campos, A.C. Gondwana Seven Proceedings. Papers presented at Seventh International Gondwana Symposium. 
Anexos 
Tabela A1: Tabela dos dados obtidos a partir de ensaios microtermométricos efetuados em inclusões fluidas hospedadas em veios de calcita espática na região de Cesário Lange (Grupo I).

\begin{tabular}{|c|c|c|c|c|c|c|c|c|c|}
\hline Amostra & Campo & $N^{\circ}$ IF & Vol_med & THtot $\left({ }^{\circ} \mathrm{C}\right)$ & $\operatorname{TE}\left({ }^{\circ} \mathrm{C}\right)$ & $\operatorname{Tfg}\left({ }^{\circ} \mathrm{C}\right)$ & Salinidade & Densidade & Vol_cal \\
\hline IP-08-B & I & 1 & 5 & 77.8 & - & - & - & - & - \\
\hline IP-08-B & II & 1 & 5 & - & -52.9 & -1.3 & 2.27 & - & - \\
\hline IP-08-E & 1 & 1 & 5 & - & -52.1 & -3.1 & 5.17 & - & - \\
\hline IP-08-E & 1 & $01 \mathrm{~A}$ & 5 & - & -48.2 & -2.2 & 3.75 & - & - \\
\hline IP-08-E & I & 01B & 5 & - & -50.1 & -2.1 & 3.59 & - & - \\
\hline IP-08-E & I & 2 & 5 & - & - & 0.4 & baixa & - & - \\
\hline IP-08-E & 1 & 3 & 5 & - & -49.2 & -2.3 & 3.91 & - & - \\
\hline IP-08-E & 1 & 4 & 5 & - & -53 & -2.3 & 3.91 & - & - \\
\hline IP-08-E & I & 5 & 5 & - & -49.4 & -2.1 & 3.59 & - & - \\
\hline IP-08-E & I & 6 & 5 & - & -48.2 & -2.3 & 3.91 & - & - \\
\hline IP-08-E & 1 & 7 & 5 & - & -48.4 & - & & - & - \\
\hline IP-08-E & 1 & 8 & 5 & - & -49.8 & -2.6 & 4.39 & - & - \\
\hline IP-08-E & I & 9 & 5 & - & -47.9 & -1 & 1.76 & - & - \\
\hline IP-08-E & 1 & 10 & 5 & - & -47 & -2.2 & 3.75 & - & - \\
\hline IP-08-E & II & 11 & 5 & - & -49.3 & -1.6 & 2.77 & - & - \\
\hline IP-08-E & II & 12 & 5 & - & -51.4 & -1.4 & 2.44 & - & - \\
\hline IP-08-E & II & 13 & 5 & - & -50.4 & -2.4 & 4.07 & - & - \\
\hline IP-08-E & II & 14 & 5 & - & -49.6 & -4.5 & 7.27 & - & - \\
\hline IP-08-E & II & 15 & 5 & - & -51.4 & -3.6 & 5.94 & - & - \\
\hline IP-08-E & II & 16 & 5 & - & -49.6 & -3.6 & 5.94 & - & - \\
\hline IP-08-E & II & 17 & 5 & - & -49.1 & -3.7 & 6.09 & - & - \\
\hline IP-08-E & III & 1 & 5 & 72.1 & -49.6 & -2.9 & 4.86 & 0.99816 & 4.8 \\
\hline IP-08-E & III & 2 & 7 & 85 & - & - & - & - & - \\
\hline IP-08-E & III & 3 & 5 & 81.6 & - & - & - & - & - \\
\hline IP-08-E & III & 7 & 5 & 69.9 & - & - & - & - & - \\
\hline IP-08-E & III & 12 & 10 & - & -53.1 & - & - & - & - \\
\hline IP-08-E & III & 13 & 10 & - & -51.6 & - & - & - & - \\
\hline IP-08-E & IV & 1 & 5 & - & -50 & -2.4 & 4.07 & - & - \\
\hline IP-08-E & IV & 2 & 5 & - & -53.9 & -2.7 & 4.55 & - & - \\
\hline IP-08-F & I & 1 & 5 & 118 & - & -0.5 & 0.91 & 0.95331 & 5.4 \\
\hline IP-08-F & 1 & 3 & 5 & 109.2 & -44.4 & 0.8 & baixa & - & - \\
\hline IP-08-F & I & 4 & 5 & 108.6 & -44.4 & 0.5 & baixa & - & - \\
\hline IP-08-F & I & 6 & 5 & 96.2 & - & - & - & - & - \\
\hline IP-08-F & II & 1 & 5 & 98 & -36 & - & - & - & - \\
\hline IP-08-F & III & 1 & - & - & -51.6 & -2.3 & 3.91 & - & - \\
\hline IP-08-F & III & 2 & - & - & -52.4 & -1.9 & 3.26 & - & - \\
\hline IP-08-F & III & 3 & - & - & -50.7 & 0.6 & baixa & - & - \\
\hline IP-08-F & III & 4 & - & - & -52.4 & 0.6 & baixa & - & - \\
\hline IP-08-F & III & 5 & - & - & -50.8 & -2.2 & 3.75 & - & - \\
\hline IP-08-F & III & 6 & - & - & -53.7 & - & - & - & - \\
\hline IP-08-F & III & 8 & - & - & -51.5 & -2.2 & 3.75 & - & - \\
\hline
\end{tabular}




\begin{tabular}{|c|c|c|c|c|c|c|c|c|c|}
\hline IP-08-F & III & 9 & - & - & -51.5 & -2.2 & 3.75 & - & - \\
\hline IP-08-F & III & 10 & - & - & -51.7 & -1.1 & 1.93 & - & - \\
\hline IP-08-G & I & 1 & $5-7$ & 89.2 & -46.3 & 0.4 & baixa & - & - \\
\hline IP-08-G & 1 & 2 & $5-7$ & 86.3 & - & 1.5 & baixa & - & - \\
\hline IP-08-G & I & 3 & $5-7$ & 97.2 & - & 1 & baixa & - & - \\
\hline IP-08-G & I & 4 & $5-7$ & 102.1 & - & 1.2 & baixa & - & - \\
\hline IP-08-G & 1 & 5 & $5-7$ & 105.9 & - & - & - & - & - \\
\hline IP-08-G & I & 6 & $5-7$ & 73.2 & - & 0.7 & baixa & - & - \\
\hline IP-08-G & 1 & 7 & $5-7$ & 98 & - & 0.8 & baixa & - & - \\
\hline IP-08-G & 1 & 9 & $5-7$ & 101.2 & - & - & - & - & - \\
\hline IP-08-G & 1 & 10 & $5-7$ & 81.7 & - & - & - & - & - \\
\hline IP-08-G & 1 & 11 & $5-7$ & 104.9 & - & - & - & - & - \\
\hline IP-08-G & I & 12 & $5-7$ & 99.8 & - & 0.4 & baixa & - & - \\
\hline IP-08-G & I & 13 & $5-7$ & 96.2 & - & -0.1 & 0.23 & 0.96437 & 3.6 \\
\hline IP-08-G & 1 & 14 & $5-7$ & 110.5 & -46.5 & 0.4 & baixa & - & - \\
\hline IP-08-G & I & 15 & $5-7$ & 95.5 & - & 0.6 & baixa & - & - \\
\hline IP-08-G & I & 16 & $5-7$ & 94.7 & - & 0.6 & baixa & - & - \\
\hline IP-08-G & 1 & 17 & $5-7$ & 94.1 & - & -0.1 & 0.23 & 0.96563 & 3.5 \\
\hline IP-08-G & I & 18 & $5-7$ & 87.6 & - & - & - & - & - \\
\hline IP-08-G & 1 & 19 & $5-7$ & 103.2 & -48.7 & -0.5 & 0.91 & 0.96321 & 4.4 \\
\hline IP-08-G & I & 20 & $5-7$ & 106,2 & -43.8 & -0.7 & 1.26 & 0.96294 & 4.8 \\
\hline IP-08-G & I & 21 & $5-7$ & 103.6 & -47.8 & -1.1 & 1.93 & 0.96781 & 4.9 \\
\hline IP-08-G & 1 & 23 & $5-7$ & 118 & -48 & 2.3 & baixa & - & - \\
\hline IP-08-G & ॥ & 1 & - & 92.5 & -45.3 & 3.5 & baixa & - & - \\
\hline IP-08-G & II & 2 & - & 93.6 & - & 4 & baixa & - & - \\
\hline IP-08-G & ॥ & 3 & $7-10$ & 132.7 & -49 & -0.6 & 1.08 & 0.94319 & 6.6 \\
\hline IP-08-G & ॥ & 4 & 5 & 97.7 & -45.5 & 2.5 & baixa & - & - \\
\hline IP-08-G & II & 7 & 5 & 90.5 & - & 2.7 & baixa & - & - \\
\hline IP-08-G & ॥ & 8 & 7 & 108.7 & -47 & 2.7 & baixa & - & - \\
\hline IP-08-G & ॥ & 9 & 7 & 115.1 & - & - & - & - & - \\
\hline IP-08-G & II & 12 & 7 & 101.1 & -47 & 0.7 & baixa & - & - \\
\hline IP-08-G & II & 16 & 5 & 91.3 & - & 3.5 & baixa & - & - \\
\hline IP-08-G & II & 18 & 5 & 96.7 & -48.9 & 1.4 & baixa & - & - \\
\hline IP-08-G & III & 1 & - & - & -47.9 & 2.6 & baixa & - & - \\
\hline IP-08-G & III & 2 & - & - & -47.8 & 3.3 & baixa & - & - \\
\hline IP-08-G & III & 3 & - & - & -52.3 & 1.8 & baixa & - & - \\
\hline IP-08-G & III & 4 & - & - & -52.3 & 3.1 & baixa & - & - \\
\hline IP-08-G & III & 5 & - & - & -47.3 & 2 & baixa & - & - \\
\hline IP-08-G & III & 6 & 5 & - & -46.2 & -1.3 & 2.27 & - & - \\
\hline IP-08-G & III & 7 & - & - & -48 & 3.8 & baixa & - & - \\
\hline IP-08-G & III & 8 & - & - & -47.8 & 0.5 & baixa & - & - \\
\hline IP-08-G & III & 9 & - & - & -48.1 & 1.7 & baixa & - & - \\
\hline IP-08-G & IV & 1 & 5 & - & -48.7 & -1.6 & 2.77 & - & - \\
\hline IP-08-G & IV & 2 & - & - & -47.6 & 3.5 & baixa & - & - \\
\hline IP-08-G & IV & 3 & - & - & -48.5 & 3.1 & baixa & - & - \\
\hline IP-08-G & IV & 4 & 5 & - & -48 & -2 & 3.42 & - & - \\
\hline IP-08-G & IV & 5 & - & - & -48.9 & 3.1 & baixa & - & - \\
\hline IP-08-G & IV & 6 & 5 & - & - & -2.4 & 4.07 & - & - \\
\hline
\end{tabular}




\begin{tabular}{|c|c|c|c|c|c|c|c|c|c|}
\hline IP-08-G & IV & 7 & - & - & -53.2 & 3.9 & baixa & - & - \\
\hline IP-08-G & IV & 8 & 5 & - & -46 & -0.7 & 1.26 & - & - \\
\hline IP-08-G & IV & 9 & - & - & -46.5 & 5.1 & baixa & - & - \\
\hline IP-08-G & V & 1 & $<5$ & 81.9 & - & -0.1 & 0.23 & 0.97252 & 2.8 \\
\hline IP-08-G & V & 2 & $\sim 5$ & 106.4 & - & -0.7 & 1.26 & 0.96282 & 4.8 \\
\hline IP-08-G & V & 3 & 5 & 109.4 & - & - & - & - & - \\
\hline IP-08-G & v & 4 & 5 & 97.3 & - & - & - & - & - \\
\hline IP-08-G & V & 5 & 5 & 103.4 & - & 1 & baixa & - & - \\
\hline IP-08-G & V & 6 & 5 & 103.4 & - & 1.3 & baixa & - & - \\
\hline IP-08-G & V & 7 & $\sim 5$ & 97.6 & - & 1 & baixa & - & - \\
\hline IP-08-G & V & 8 & $\sim 5$ & 98.4 & - & - & - & - & - \\
\hline IP-08-G & V & 9 & $\sim 5$ & 107.9 & - & - & - & - & - \\
\hline IP-08-G & V & 10 & $<5$ & 89.1 & - & 0.6 & baixa & - & - \\
\hline IP-08-G & V & 11 & $\sim 5$ & 106.7 & -48.7 & 0.3 & baixa & - & - \\
\hline IP-08-G & v & 12 & $\sim 5$ & 104.8 & - & - & - & - & - \\
\hline IP-08-G & V & 13 & $\sim 5$ & 109.7 & - & - & - & - & - \\
\hline IP-08-G & v & 14 & $\sim 5$ & 111 & - & - & - & - & - \\
\hline IP-08-G & V & 15 & $\sim 5$ & 107.1 & - & - & - & - & - \\
\hline IP-08-G & $\mathrm{V}$ & 16 & $\sim 5$ & 105.6 & - & - & - & - & - \\
\hline IP-08-G & v & 17 & $\sim 5$ & 102.6 & - & - & - & - & - \\
\hline IP-08-G & V & 18 & $<5$ & 98.7 & - & - & - & - & - \\
\hline IP-08-G & $\mathrm{VI}$ & 1 & $5-10$ & 103.1 & - & 0.9 & baixa & - & - \\
\hline IP-08-G & VI & 3 & $5-10$ & 105.2 & - & - & - & - & - \\
\hline IP-08-G & VI & 4 & $5-10$ & 93.9 & -49.1 & - & - & - & - \\
\hline IP-08-G & VI & 5 & $5-10$ & 139.3 & - & - & - & - & - \\
\hline IP-08-G & VI & 6 & $5-10$ & 116.2 & - & 3 & baixa & - & - \\
\hline IP-08-G & VI & 7 & $5-10$ & 138.9 & - & 0.7 & baixa & - & - \\
\hline IP-08-G & VI & 8 & $5-10$ & 103.8 & - & 1.7 & baixa & - & - \\
\hline IP-08-G & $\mathrm{VI}$ & 9 & $5-10$ & 96.7 & - & - & - & - & - \\
\hline IP-08-G & VI & 10 & $5-10$ & 82 & - & - & - & - & - \\
\hline IP-08-G & VI & 11 & $5-10$ & 108.2 & - & - & - & - & - \\
\hline IP-08-G & $\mathrm{VI}$ & 12 & $5-10$ & 141.3 & - & - & - & - & - \\
\hline IP-08-G & VI & 13 & $5-10$ & 128.5 & - & - & - & - & - \\
\hline IP-08-H & I & 1 & $<10$ & 105.7 & -46.4 & -0.9 & 1.59 & 0.96489 & 4.9 \\
\hline IP-08-H & 1 & 2 & 7 & 98.7 & -45.5 & 3.1 & baixa & - & - \\
\hline IP-08-H & I & 3 & 10 & 112.4 & -48.7 & -1.1 & 1.93 & 0.96225 & 5.5 \\
\hline IP-08-H & I & 4 & $<10$ & 97.2 & -47.5 & 2.3 & baixa & - & - \\
\hline IP-08-H & 1 & 5 & 4 & - & -47.2 & -0.1 & 0.23 & 0.95987 & - \\
\hline IP-08-H & II & 1 & - & 107.6 & - & - & - & - & - \\
\hline IP-08-H & ॥ & 2 & - & 105.4 & - & - & - & - & - \\
\hline IP-08-H & ॥ & 3 & - & 102 & -47.6 & -1.2 & 2.1 & 0.96958 & 4.9 \\
\hline IP-08-H & II & 4 & - & 127.3 & - & - & - & - & - \\
\hline IP-08-H & II & 5 & - & 123.5 & - & - & - & - & - \\
\hline |P-08-I & I & 2 & $<10$ & 105.4 & - & - & - & - & - \\
\hline |P-08-I & I & 3 & $<10$ & 103.5 & - & - & - & - & - \\
\hline |P-08-I & I & 4 & $<10$ & 87.7 & - & - & - & - & - \\
\hline |P-08-I & 1 & 5 & $<10$ & 96.3 & - & - & - & - & - \\
\hline IP-08-I & I & 6 & $<10$ & 111.2 & - & - & - & - & - \\
\hline
\end{tabular}




\begin{tabular}{|c|c|c|c|c|c|c|c|c|c|}
\hline IP-08-I & 1 & 7 & $<10$ & 109.8 & - & - & - & - & - \\
\hline |P-08-I & 1 & 10 & $<10$ & 102.7 & - & - & - & - & - \\
\hline |P-08-I & 1 & $10 \mathrm{~A}$ & $<10$ & 104.2 & - & - & - & - & . \\
\hline |P-08-I & 1 & 11 & $<10$ & 108.5 & - & - & - & - & - \\
\hline |P-08-I & 1 & 13 & $<10$ & 123 & - & - & - & - & - \\
\hline |P-08-I & 1 & 14 & $<10$ & 82.6 & - & - & - & - & - \\
\hline |P-08-I & 1 & 15 & $<10$ & 110.2 & - & - & - & - & 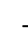 \\
\hline |P-08-I & 1 & 16 & $<10$ & 83.3 & - & - & - & - & . \\
\hline |P-08-| & I & 17 & $<10$ & 99.7 & - & - & - & - & - \\
\hline |P-08-I & 1 & 18 & $<10$ & 104.8 & - & - & - & - & - \\
\hline |P-08-| & I & 19 & $<10$ & 99.4 & - & - & - & - & - \\
\hline |P-08-I & 1 & 20 & $<10$ & 99.4 & - & - & - & - & - \\
\hline |P-08-I & 1 & 21 & $<10$ & 90.3 & - & - & - & - & - \\
\hline |P-08-| & I & 22 & $<10$ & 106.2 & - & - & - & - & - \\
\hline |P-08-I & 1 & 23 & $<10$ & 102.3 & - & - & - & - & - \\
\hline |P-08-| & I & 24 & $<10$ & 76.4 & - & - & - & - & - \\
\hline IP-08-I & 1 & 25 & $<10$ & 95.5 & - & - & - & - & - \\
\hline |P-08-I & 1 & 26 & $<10$ & 70.9 & - & - & - & - & - \\
\hline |P-08-| & I & 27 & $<10$ & 70.9 & - & - & - & - & - \\
\hline |P-08-I & II & 1 & $7-10$ & 109.4 & - & - & - & - & - \\
\hline |P-08-I & II & 2 & $7-10$ & 82.5 & - & - & - & - & - \\
\hline |P-08-I & II & 3 & $7-10$ & 97.2 & - & - & - & - & 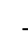 \\
\hline |P-08-I & II & 5 & $7-10$ & 78.2 & - & - & - & - & 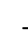 \\
\hline |P-08-| & II & 6 & $7-10$ & 94.9 & - & - & - & - & 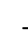 \\
\hline IP-08-I & II & 10 & $7-10$ & 99.9 & - & - & - & - & - \\
\hline |P-08-I & II & 14 & $7-10$ & 101.2 & - & - & - & - & - \\
\hline |P-08-I & II & 15 & $7-10$ & 107.7 & - & - & - & - & 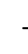 \\
\hline |P-08-I & III & 1 & $<10$ & 102.7 & - & - & - & - & - \\
\hline |P-08-I & III & 2 & $<10$ & 94 & - & - & - & - & - \\
\hline IP-08-I & III & 3 & $<10$ & 106.4 & - & - & - & - & - \\
\hline |P-08-I & III & 4 & $<10$ & 93.3 & - & - & - & - & 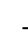 \\
\hline |P-08-I & III & 5 & $<10$ & 104.3 & - & - & - & - & 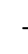 \\
\hline |P-08-I & III & 6 & $<10$ & 100.9 & - & - & - & - & - \\
\hline |P-08-I & III & 7 & $<10$ & 102.1 & - & - & - & - & - \\
\hline
\end{tabular}

$\mathrm{N}^{\circ} \mathrm{IF}=$ número da inclusão fluida; Vol_med=volume medido; THtot=Temperatura de Homogeneização total; TE=Temperatura Eutética; Tfg=Temperatura de fusão do gelo; Vol_cal=volume calculado. 
Tabela A2: Tabela dos dados obtidos a partir de ensaios microtermométricos efetuados em inclusões fluidas hospedadas em veio de calcita espática na região de Paraisolândia (Grupo II).

\begin{tabular}{|c|c|c|c|c|c|c|c|c|c|}
\hline Amostra & Campo & $\mathbf{N}^{\circ}$ IF & Vol_med & THtot $\left({ }^{\circ} \mathrm{C}\right)$ & $\operatorname{TE}\left({ }^{\circ} \mathrm{C}\right)$ & $\operatorname{Tfg}\left({ }^{\circ} \mathrm{C}\right)$ & Salinidade & Densidade & Vol_cal \\
\hline \multirow[t]{15}{*}{ MS-2B } & $\mathrm{C} 1$ & 2 & 5 & 124.7 & - & - & - & - & - \\
\hline & & 3 & $7-10$ & 155.3 & - & - & - & - & - \\
\hline & & 4 & 10 & 136.8 & - & - & - & - & - \\
\hline & & 5 & $7-10$ & 128.5 & - & - & - & - & - \\
\hline & & 6 & $7-10$ & 135 & - & - & - & - & - \\
\hline & & 7 & 10 & 168.4 & - & - & - & - & - \\
\hline & & 8 & 7 & 127.3 & - & - & - & - & - \\
\hline & & 9 & 7 & 122.7 & - & - & - & - & - \\
\hline & & 10 & $7-10$ & 122.7 & - & - & - & - & - \\
\hline & & 11 & $7-10$ & 158 & - & - & - & - & - \\
\hline & & 12 & 7 & 85.3 & - & - & - & - & - \\
\hline & & 13 & 7 & 73.5 & - & - & - & - & - \\
\hline & & 14 & 10 & 103.9 & - & - & - & - & - \\
\hline & & 15 & 7 & 91.1 & - & - & - & - & - \\
\hline & & 16 & 7 & 93.9 & - & - & - & - & - \\
\hline \multirow[t]{25}{*}{ MS-2B } & $\mathrm{C} 2$ & 1 & 12 & - & & -1.1 & 1.93 & 0.890487 & - \\
\hline & & 2 & $10-15$ & - & -54.1 & 0.5 & baixa & - & - \\
\hline & & 3 & $10-15$ & - & -53.7 & 0.4 & baixa & - & - \\
\hline & & 4 & $10-15$ & 145.6 & -52.9 & -0.1 & 0.23 & 0.927366 & 7.3 \\
\hline & & 5 & $10-15$ & 147.2 & -54.3 & -0.4 & 0.74 & 0.929017 & 7.6 \\
\hline & & 6 & $10-15$ & 168.2 & - & - & - & - & - \\
\hline & & 7 & $10-15$ & 142.9 & - & - & - & - & - \\
\hline & & 8 & $10-15$ & 141.4 & - & -1.8 & 3.1 & 0.947639 & 8 \\
\hline & & 9 & $10-15$ & 138.8 & - & 2.5 & baixa & - & - \\
\hline & & 10 & $10-15$ & & - & 2.5 & baixa & - & - \\
\hline & & 11 & $10-15$ & 142.6 & - & - & - & - & - \\
\hline & & 12 & $10-15$ & 138.8 & - & - & - & - & - \\
\hline & & 13 & $10-15$ & 140 & - & - & - & - & - \\
\hline & & 14 & $10-15$ & 123.3 & - & - & - & - & - \\
\hline & & 15 & $10-15$ & 137.5 & - & - & - & - & - \\
\hline & & 19 & $10-15$ & 146.1 & - & - & - & - & - \\
\hline & & 20 & $10-15$ & 162.4 & - & -0.3 & 0.52 & 0.913515 & 9 \\
\hline & & 21 & $10-15$ & 170 & - & - & - & - & - \\
\hline & & 22 & $10-15$ & 170 & - & - & - & - & - \\
\hline & & 23 & 20 & 170 & -54.9 & 0 & 0 & 0.902994 & 9.5 \\
\hline & & 24 & $10-15$ & 128.3 & - & - & - & - & - \\
\hline & & 25 & 15 & 148 & -55 & 0.1 & baixa & - & - \\
\hline & & 26 & 5 & 120 & - & - & - & - & - \\
\hline & & 27 & $10-15$ & 156.5 & -55 & 0 & 0 & 0.915359 & 8.3 \\
\hline & & 28 & $10-15$ & 146.3 & -54.3 & -1.5 & 2.6 & 0.940856 & 8.2 \\
\hline
\end{tabular}




\begin{tabular}{|c|c|c|c|c|c|c|c|c|c|}
\hline & & 29 & $10-15$ & 172.1 & - & -0.1 & 0.23 & 0.901007 & 10 \\
\hline & & 30 & $10-15$ & - & - & 2.7 & baixa & - & - \\
\hline & & A & $10-15$ & 107 & - & - & - & - & - \\
\hline & & B & $10-15$ & 173.2 & - & - & - & - & - \\
\hline & & C & $10-15$ & 170 & - & - & - & - & - \\
\hline & & D & $10-15$ & 179.5 & -56 & -0.2 & 0.4 & 0.894014 & 10.8 \\
\hline & & $\mathrm{E}$ & $10-15$ & 154 & - & - & - & - & - \\
\hline & & $\mathrm{F}$ & $10-15$ & 167.8 & - & - & - & - & - \\
\hline & & G & $10-15$ & - & - & 0.1 & baixa & - & - \\
\hline MS-2B & C3 & 1 & 10 & 176.1 & - & -0.3 & 0.52 & 0.899086 & 10.5 \\
\hline & & 2 & 10 & 176.8 & - & -0.3 & 0.57 & 0.898312 & 10.5 \\
\hline & & 3 & 10 & 179.9 & - & -0.3 & 0.57 & 0.89484 & 10.9 \\
\hline & & 6 & 10 & 168.2 & - & -0.2 & 0.4 & 0.906385 & 9.6 \\
\hline & & 7 & 10 & 180.5 & -52.2 & -0.2 & 0.4 & 0.892873 & 10.9 \\
\hline & & 8 & 10 & 175 & - & 2.5 & baixa & - & - \\
\hline & & 10 & 10 & 185 & - & 1.8 & baixa & - & - \\
\hline & & 11 & 10 & 114.8 & -51.5 & 1.8 & baixa & - & - \\
\hline & & 12 & 5 & 108.1 & -51.1 & -1.4 & 2.44 & 0.967465 & 5.4 \\
\hline & & 13 & 10 & 139.1 & -51.1 & -1.3 & 2.27 & 0.950301 & 7 \\
\hline & & 14 & 10 & 146.5 & - & -1.6 & 2.77 & 0.941663 & 8.3 \\
\hline & & 15 & 5 & 124.5 & - & -0.2 & 0.4 & 0.94587 & 5.6 \\
\hline & & 16 & 10 & 152.8 & - & -0.4 & 0.74 & 0.923907 & 8.1 \\
\hline & & 18 & 10 & 147 & -53 & 2.3 & baixa & - & - \\
\hline & & 19 & 10 & 146.1 & -52.8 & 2 & baixa & - & - \\
\hline & & 20 & 10 & 136.2 & - & 0 & 0 & 0.93192 & 6.6 \\
\hline & & 21 & 10 & 142.5 & - & 2.5 & baixa & - & - \\
\hline & & 22 & 10 & 145.6 & - & 2.3 & baixa & - & - \\
\hline & & 24 & 10 & 123.3 & - & - & - & - & - \\
\hline & & 25 & 10 & 97.7 & - & - & - & - & - \\
\hline & & 26 & 10 & 162.1 & -52.3 & -0.2 & 0.4 & 0.912676 & 8.9 \\
\hline & & $A$ & 10 & 149.1 & - & -0.2 & 0.4 & 0.925211 & 7.7 \\
\hline MS-2B & C4 & 2 & $5-10$ & 130 & - & 2.3 & baixa & - & - \\
\hline & & 3 & $5-10$ & 138.5 & - & -0.3 & 0.57 & 0.935569 & 6.8 \\
\hline & & 4 & $5-10$ & 126 & -53.7 & -0.3 & 0.57 & 0.94563 & 5.8 \\
\hline & & 6 & $5-10$ & 130.5 & -55.4 & -0.4 & 0.74 & 0.943054 & 6.2 \\
\hline & & 8 & $5-10$ & 136.6 & - & -1.1 & 1.93 & 0.944834 & 7.2 \\
\hline & & 9 & $5-10$ & 100.8 & - & - & - & - & - \\
\hline & & 14 & $5-10$ & 115.7 & - & - & - & - & - \\
\hline & & 15 & $5-10$ & 156.1 & - & 0 & 0 & 0.915708 & 8.3 \\
\hline & & 16 & $5-10$ & 142.1 & -56.7 & 2.3 & baixa & - & - \\
\hline & & 17 & $5-10$ & 144.3 & -55.7 & 2.6 & baixa & - & - \\
\hline & & 18 & $5-10$ & 144.3 & -54.6 & 2.4 & baixa & - & - \\
\hline & & 20 & $5-10$ & 127 & -56.5 & 2.4 & baixa & - & - \\
\hline & & 21 & $5-10$ & 131.5 & -56.3 & 2.3 & baixa & - & - \\
\hline & & 22 & $5-10$ & 137.3 & -55.8 & 2.2 & baixa & - & - \\
\hline & & 23 & $5-10$ & 143.6 & -56.8 & -0.6 & 1.08 & 0.93421 & 7.4 \\
\hline
\end{tabular}




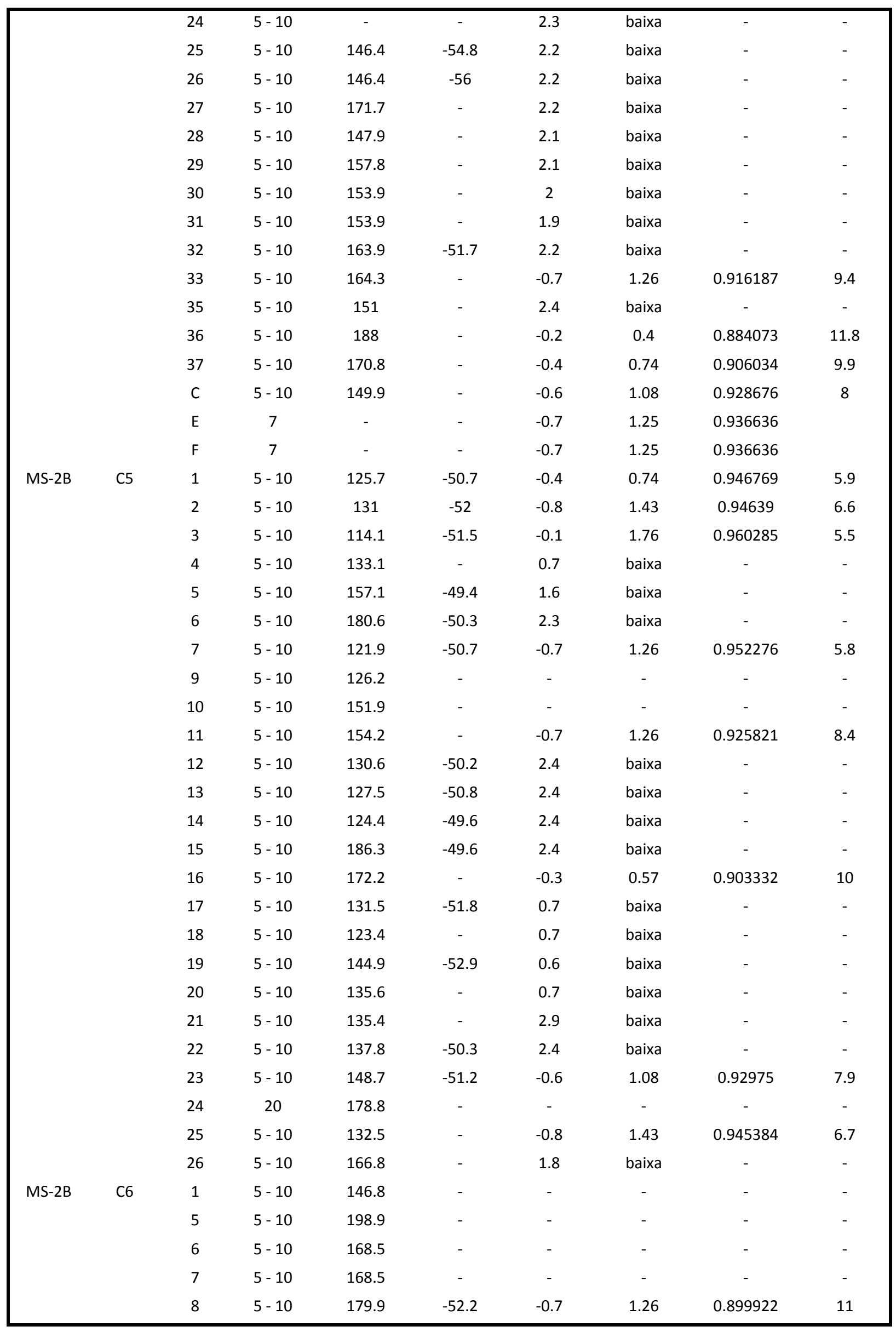




\begin{tabular}{|c|c|c|c|c|c|c|c|c|c|}
\hline & & 9 & $5-10$ & 152.8 & - & -0.5 & 0.91 & 0.924977 & 8.2 \\
\hline & & 10 & $5-10$ & 170.7 & -52.1 & -0.4 & 0.74 & 0.90614 & 9.9 \\
\hline & & 11 & $5-10$ & 170.7 & -51.8 & -0.1 & 0.23 & 0.902525 & 9.8 \\
\hline & & 12 & $5-10$ & 173.8 & - & 0 & 0 & 0.899299 & 9.9 \\
\hline & & 13 & $5-10$ & 146.8 & - & -1 & 1.76 & 0.935491 & 7.9 \\
\hline & & 14 & $5-10$ & 146.6 & -50.5 & -0.6 & 1.08 & 0.931607 & 7.7 \\
\hline & & 15 & $5-10$ & 192.1 & - & -0.8 & 1.43 & 0.887329 & 12.4 \\
\hline & & 16 & $5-10$ & 150.4 & - & - & - & - & - \\
\hline & & 17 & $5-10$ & 118.9 & - & 2.5 & baixa & - & - \\
\hline & & 18 & $5-10$ & 131.1 & - & -0.5 & 0.91 & 0.943517 & 6.4 \\
\hline & & 19 & $5-10$ & 147.3 & - & -0.7 & 1.26 & 0.932016 & 7.8 \\
\hline & & 20 & $5-10$ & 145.2 & -52.5 & -0.6 & 1.08 & 0.932829 & 7.6 \\
\hline & & 21 & $5-10$ & 139 & - & -0.1 & 0.23 & 0.93318 & 6.7 \\
\hline & & 22 & $5-10$ & 138.2 & -52 & 2.2 & baixa & - & - \\
\hline & & 23 & $5-10$ & 191.1 & - & -0.8 & 1.43 & 0.888505 & 12.3 \\
\hline & & 24 & $5-10$ & 137.5 & -52.4 & 2.4 & baixa & & \\
\hline & & 25 & $5-10$ & 159.7 & -52.1 & -1.3 & 2.27 & 0.927172 & 9.2 \\
\hline & & 26 & $5-10$ & 180.4 & - & -1 & 1.76 & 0.903119 & 11.1 \\
\hline & & 27 & $5-10$ & 183 & - & -0.9 & 1.59 & 0.899031 & 11.4 \\
\hline & & 28 & $5-10$ & 190.9 & -53.2 & -0.6 & 1.08 & 0.886039 & 12.2 \\
\hline & & 29 & $5-10$ & 182.4 & -51.7 & -0.8 & 1.43 & 0.898427 & 11.3 \\
\hline & & 30 & $5-10$ & 176.9 & - & -0.6 & 1.08 & 0.901948 & 10.6 \\
\hline & & 31 & $5-10$ & 171.3 & -51.7 & -0.7 & 1.26 & 0.909101 & 10.1 \\
\hline & & 32 & $5-10$ & 225.7 & - & -1 & 1.76 & 0.846553 & 16.7 \\
\hline & & 33 & $5-10$ & 216.4 & - & -0.7 & 1.26 & 0.854753 & 15.5 \\
\hline & & 34 & $5-10$ & 210.4 & - & -0.9 & 1.59 & 0.865948 & 14.6 \\
\hline & & 35 & $5-10$ & 132.3 & -54.5 & -0.6 & 1.08 & 0.94351 & 6.5 \\
\hline & & 36 & $5-10$ & 125 & -51.2 & -1 & 1.76 & 0.952694 & 6.3 \\
\hline & & 37 & $5-10$ & 125.2 & - & -0.8 & 1.43 & 0.95076 & 6.1 \\
\hline & & 38 & $5-10$ & 178.4 & -51.6 & -0.2 & 0.4 & 0.89526 & 10.7 \\
\hline & & 39 & $5-10$ & 149.9 & -52.3 & -0.5 & 0.91 & 0.92763 & 7.9 \\
\hline & & 40 & $5-10$ & 151.7 & -52.8 & -0.6 & 1.08 & 0.927048 & 8.1 \\
\hline & & 41 & $5-10$ & 132.6 & -52.6 & -0.6 & 1.08 & 0.943274 & 6.5 \\
\hline & & 42 & $5-10$ & 132.7 & -51.9 & -0.3 & 0.57 & 0.940357 & 6.3 \\
\hline & & 43 & $5-10$ & 148.5 & -51.4 & -0.6 & 1.08 & 0.929928 & 7.9 \\
\hline & & 44 & $5-10$ & 140.6 & - & -0.6 & 1.08 & 0.936756 & 7.2 \\
\hline & & 45 & $5-10$ & 149.5 & -50.9 & -1.5 & 2.6 & 0.938191 & 8.5 \\
\hline & & 46 & $5-10$ & 165.3 & -52.9 & 1.5 & baixa & - & - \\
\hline & & 47 & $5-10$ & 221.1 & - & -0.8 & 1.43 & 0.849799 & 16.1 \\
\hline & & 48 & $5-10$ & 188.6 & -52.8 & -0.5 & 0.91 & 0.887411 & 11.9 \\
\hline & & $A$ & $5-10$ & 147.8 & - & - & - & - & - \\
\hline MS-2B & $\mathrm{C7}$ & 2 & $5-10$ & 163.7 & -51.2 & -0.2 & 0.4 & 0.911052 & 9.1 \\
\hline & & 3 & $5-10$ & 106.7 & - & -0.2 & 0.4 & 0.958517 & 4.4 \\
\hline & & 4 & $5-10$ & 165.4 & - & -0.7 & 1.26 & 0.915096 & 9.5 \\
\hline & & 5 & $5-10$ & 165.2 & -52.6 & 0 & 0 & 0.907524 & 9.1 \\
\hline & & 6 & $5-10$ & 117.3 & -51.1 & -0.2 & 0.4 & 0.951207 & 5.1 \\
\hline
\end{tabular}




\begin{tabular}{|c|c|c|c|c|c|c|c|c|c|}
\hline & & 7 & $5-10$ & 167.1 & - & 0.3 & baixa & - & - \\
\hline & & 8 & $5-10$ & 185.3 & - & -0.2 & 0.4 & 0.887291 & 11.5 \\
\hline & & 9 & $5-10$ & 185.3 & - & -0.5 & 0.91 & 0.891265 & 11.5 \\
\hline & & 10 & $5-10$ & 182.3 & - & 0 & 0 & 0.890671 & 10.8 \\
\hline & & 11 & $5-10$ & 151.3 & - & -0.2 & 0.4 & 0.923171 & 7.9 \\
\hline & & 12 & $5-10$ & 151.3 & - & -0.3 & 0.52 & 0.924234 & 8 \\
\hline & & 13 & $5-10$ & 99.6 & - & -0.2 & 0.4 & 0.963064 & 3.9 \\
\hline & & 14 & $5-10$ & 174.3 & -51.9 & -0.5 & 0.91 & 0.903521 & 10.3 \\
\hline & & 15 & $5-10$ & 176.6 & - & -0.7 & 1.26 & 0.903507 & 10.6 \\
\hline & & 16 & $5-10$ & 176.2 & - & - & - & - & - \\
\hline & & 17 & $5-10$ & 154.9 & - & - & - & - & - \\
\hline & & 18 & $5-10$ & 175.4 & - & - & - & - & - \\
\hline & & 19 & $5-10$ & 149.7 & - & 0 & 0 & 0.921163 & 7.7 \\
\hline & & 20 & $5-10$ & 121.8 & - & -0.1 & 0.23 & 0.947023 & 5.4 \\
\hline & & 21 & $5-10$ & 166.5 & - & -0.3 & 0.57 & 0.909339 & 9.4 \\
\hline & & 22 & $5-10$ & 166.5 & - & -0.4 & 0.74 & 0.91051 & 9.5 \\
\hline & & 23 & $5-10$ & 201.1 & -49.3 & -1.1 & 1.93 & 0.880648 & 13.5 \\
\hline & & 24 & $5-10$ & 188.9 & -51.3 & -0.5 & 0.91 & 0.887057 & 12 \\
\hline & & 25 & $5-10$ & 138.8 & -52.2 & -0.5 & 0.91 & 0.937279 & 7 \\
\hline & & 26 & $5-10$ & 138.3 & -50.9 & -0.5 & 0.91 & 0.937695 & 6.9 \\
\hline & & 27 & $5-10$ & 153.7 & -51.5 & -0.5 & 0.91 & 0.924142 & 8.3 \\
\hline & & 28 & $5-10$ & 154.1 & -52.6 & -0.4 & 0.74 & 0.922691 & 8.3 \\
\hline & & 29 & $5-10$ & 203.9 & - & -0.4 & 0.74 & 0.866949 & 13.8 \\
\hline & & 30 & 7 & - & - & -0.6 & 1.08 & 0.935513 & - \\
\hline & & 31 & $5-10$ & 183 & -51 & -0.3 & 0.57 & 0.891296 & 11.2 \\
\hline & & 33 & $5-10$ & 140.4 & - & 2.1 & baixa & - & - \\
\hline & & 34 & $5-10$ & 193 & - & -0.4 & 0.74 & 0.880755 & 12.4 \\
\hline & & 35 & $5-10$ & 206.6 & -52.6 & -0.3 & 0.57 & 0.861856 & 14.2 \\
\hline & & 36 & $5-10$ & 217 & - & -0.2 & 0.4 & 0.845804 & 15.6 \\
\hline & & 37 & $5-10$ & 174.7 & - & -0.1 & 0.23 & 0.898148 & 10.2 \\
\hline & & A & $5-10$ & 192.3 & - & -0.9 & 1.59 & 0.888441 & 12.4 \\
\hline & & B & $5-10$ & - & - & 1.9 & baixa & - & - \\
\hline & & $\mathrm{C}$ & $5-10$ & - & - & 1.9 & baixa & - & - \\
\hline MS-2B & $\mathrm{C} 8$ & 1 & $5-10$ & 145,9 & -55.2 & -1.9 & 3.26 & 0.945024 & 8.4 \\
\hline & & 3 & $5-10$ & 126.9 & - & 3.4 & baixa & - & - \\
\hline & & 5 & $5-10$ & 147.2 & - & - & - & - & - \\
\hline & & 6 & $5-10$ & 117.1 & - & 4.3 & baixa & - & - \\
\hline & & 7 & $5-10$ & 135.9 & - & - & - & - & - \\
\hline & & A & $5-10$ & 130.4 & - & - & - & - & - \\
\hline & & B & $5-10$ & - & -52.6 & - & - & - & - \\
\hline
\end{tabular}

$\mathrm{N}^{\circ} \mathrm{IF}=$ número da inclusão fluida; Vol_med=volume medido; THtot=Temperatura de Homogeneização total; TE=Temperatura Eutética; Tfg=Temperatura de fusão do gelo; Vol_cal=volume calculado. 
Tabela A3: Tabela dos dados obtidos a partir de ensaios microtermométricos efetuados em inclusões fluidas hospedadas em veio de quartzo na região de Paraisolândia (Grupo III).

\begin{tabular}{|c|c|c|c|c|c|c|c|c|c|}
\hline Amostra & Campo & $\mathbf{N}^{\circ}$ IF & Vol_med & THtot $\left({ }^{\circ} \mathrm{C}\right)$ & $\operatorname{TE}\left({ }^{\circ} \mathrm{C}\right)$ & $\operatorname{Tfg}\left({ }^{\circ} \mathrm{C}\right)$ & Salinidade & Densidade & Vol_cal \\
\hline \multirow[t]{35}{*}{ MS-2D-L1 } & \multirow[t]{35}{*}{1} & 1 & $\sim 10$ & 168.5 & -43.2 & -1.9 & 3.26 & 0.925449 & 10.3 \\
\hline & & 4 & $5-10$ & 96.1 & -45.6 & -11.2 & 15.46 & 1.050135 & 9.7 \\
\hline & & 5 & $\sim 7$ & - & -45.3 & -5.5 & 8.68 & 0.985098 & - \\
\hline & & 6 & $\sim 7$ & - & -45.1 & -12.1 & 16.37 & $1,035,166$ & - \\
\hline & & 7 & $\sim 7$ & - & -45.1 & -11.1 & 15.35 & $1,028,570$ & - \\
\hline & & 8 & $\sim 7$ & - & - & -2.4 & 4.07 & 0.955086 & - \\
\hline & & 9 & $\sim 7$ & - & -47.7 & -11.1 & 15.35 & $1,028,570$ & - \\
\hline & & 10 & $5-10$ & 90.1 & -45.6 & -9.9 & 14.07 & 1.043681 & 9 \\
\hline & & 11 & $5-10$ & 78.7 & -45.6 & -11.1 & 15.35 & 1.061458 & 8.6 \\
\hline & & 12 & $\sim 25$ & 307.5 & -45.6 & -10.7 & 14.93 & 0.867717 & 25 \\
\hline & & 13 & $5-10$ & 102.8 & -45.2 & - & - & - & - \\
\hline & & 14 & $5-10$ & - & -45.7 & - & - & - & - \\
\hline & & 15 & $\sim 10$ & - & -40 & 0.8 & Baixa & - & - \\
\hline & & 16 & $\sim 7$ & - & -40 & -0.2 & 0.4 & 0.930998 & - \\
\hline & & 17 & $\sim 25$ & 206.3 & -52.2 & 0.8 & Baixa & - & - \\
\hline & & 18 & $5-10$ & 119 & & 0.2 & Baixa & - & - \\
\hline & & 19 & $5-10$ & 283.8 & -44.7 & 0.3 & Baixa & - & - \\
\hline & & 20 & $5-10$ & - & -44.7 & 1.1 & Baixa & - & - \\
\hline & & A & - & 65,1 & - & - & - & - & - \\
\hline & & B & - & 112.3 & -50.6 & -14.6 & 18.7 & - & - \\
\hline & & C & - & 115.1 & -51.3 & -0.4 & 0.74 & - & - \\
\hline & & D & - & 120.2 & - & - & - & - & - \\
\hline & & $\mathrm{E}$ & - & 122.7 & - & - & - & - & - \\
\hline & & $F$ & - & 123.6 & - & - & - & - & - \\
\hline & & G & - & 123.9 & - & - & - & - & - \\
\hline & & $\mathrm{H}$ & - & 124 & - & - & - & - & - \\
\hline & & 1 & - & 124 & - & - & - & - & - \\
\hline & & J & - & 112.3 & -50.1 & -6.3 & 9.75 & - & - \\
\hline & & K & - & 127.9 & -48.5 & -0.3 & 0.57 & - & - \\
\hline & & L & - & 129.3 & - & -0.2 & 0.4 & - & - \\
\hline & & $\mathrm{M}$ & - & 130.7 & - & - & - & - & - \\
\hline & & $\mathrm{N}$ & - & 138.3 & -50.1 & 0 & 0 & - & - \\
\hline & & 0 & - & 158 & -49.9 & -18.2 & 21.67 & - & - \\
\hline & & $P$ & - & 178 & - & - & - & - & - \\
\hline & & $\mathrm{Q}$ & - & 200.8 & -49.2 & -0.6 & 1.08 & - & - \\
\hline \multirow[t]{6}{*}{ MS-2D-L1 } & \multirow[t]{6}{*}{ II } & 1 & $5-10$ & 133.4 & -52.6 & - & - & - & - \\
\hline & & 2 & $5-10$ & 124.5 & -51.8 & -5.6 & 8.81 & 0.990400 & 9.1 \\
\hline & & 3 & $\sim 7$ & - & -52.7 & -2.6 & 4.39 & 0.957167 & - \\
\hline & & 4 & $5-10$ & 120 & -54.1 & -5.5 & 8.68 & 0.992382 & 8.8 \\
\hline & & 5 & $\sim 7$ & 134.1 & -52.5 & -5.4 & 8.54 & 0.984203 & - \\
\hline & & 6 & $5-10$ & 123.3 & -53.6 & -4.5 & 7.27 & 0.982776 & 8.5 \\
\hline
\end{tabular}




\begin{tabular}{|c|c|c|c|c|c|c|c|c|c|}
\hline & & 7 & $5-10$ & 116.2 & -53 & -1.2 & 2.1 & 0.960572 & 5.8 \\
\hline & & 8 & $5-10$ & 121.8 & - & -2.1 & 3.59 & 0.964428 & 6.8 \\
\hline & & 9 & $5-10$ & 120.8 & -52.7 & -5.4 & 8.54 & 0.99115 & 8.8 \\
\hline & & 10 & $\sim 7$ & - & -54.1 & -4.5 & 7.27 & 0.975935 & - \\
\hline & & 11 & $5-10$ & 119.3 & -52.7 & -5.4 & 8.54 & 0.992052 & 8.7 \\
\hline & & 12 & $5-10$ & 128.1 & -54.2 & -5.1 & 8.12 & 0.984391 & 9.1 \\
\hline & & 13 & $5-10$ & 134.5 & -53.8 & -5.3 & 8.4 & 0.981838 & 9.6 \\
\hline & & 14 & $\sim 7$ & - & -51.9 & -5.6 & 8.81 & 0.985988 & - \\
\hline & & 15 & $5-10$ & 117.6 & -49.5 & -1.6 & 2.77 & 0.963016 & 6.2 \\
\hline & & 16 & $5-10$ & 122.8 & -50.3 & -5.5 & 8.68 & 0.990689 & 9 \\
\hline & & A & $5-10$ & 115.6 & - & - & - & - & - \\
\hline & & B & $5-10$ & 121 & - & - & - & - & - \\
\hline & & C & $5-10$ & 113.6 & - & - & - & - & - \\
\hline & & D & $5-10$ & 107.6 & - & - & - & - & - \\
\hline & & $E$ & $5-10$ & 114.7 & - & - & - & - & - \\
\hline & & $\mathrm{F}$ & $5-10$ & 131 & - & - & - & - & - \\
\hline MS-2D-L1 & III & 1 & - & - & -49.3 & -0.5 & - & - & - \\
\hline & & 2 & - & - & -48.1 & -0.4 & - & - & - \\
\hline & & 3 & - & - & -49.7 & 1.1 & Baixa & - & - \\
\hline & & 4 & - & - & -54.2 & -2.5 & - & - & - \\
\hline & & 5 & - & - & -51.7 & -0.9 & - & - & - \\
\hline & & 6 & - & - & -49.6 & 1 & Baixa & - & - \\
\hline & & 7 & - & - & -44.3 & -0.8 & - & - & - \\
\hline & & 8 & - & - & - & -0.4 & - & - & - \\
\hline & & 9 & - & - & -53.3 & -0.6 & - & - & - \\
\hline & & 10 & - & - & -53.1 & -0.3 & - & - & - \\
\hline MS-2D-L1 & IV & 1 & $\sim 20$ & 143.9 & -53.8 & 3.5 & Baixa & - & - \\
\hline & & 2 & $\sim 20$ & 125.4 & - & -0.2 & 0.4 & 0.945181 & 7.5 \\
\hline & & 3 & $\sim 20$ & 149.8 & -53.4 & 2.4 & Baixa & & \\
\hline & & 4 & $\sim 20$ & 148.8 & - & 0 & 0 & 0.921911 & 7.6 \\
\hline & & 5 & $\sim 20$ & 221.4 & -50.5 & -2.4 & 4.07 & 0.873858 & 16 \\
\hline & & 6 & $\sim 20$ & 152.2 & - & 2.4 & Baixa & - & - \\
\hline & & 7 & $\sim 20$ & 193.5 & -50 & -1.3 & 2.27 & 0.892367 & 12.6 \\
\hline & & 8 & $\sim 20$ & 127.1 & - & 2.2 & Baixa & - & - \\
\hline & & 9 & $\sim 20$ & 128.8 & -50.1 & 4.9 & Baixa & - & - \\
\hline & & 10 & $\sim 20$ & 159.3 & - & -0.2 & 0.4 & 0.915475 & 8.7 \\
\hline & & 11 & $\sim 20$ & - & -55 & -1.9 & 3.26 & 0.817033 & - \\
\hline & & 12 & $\sim 20$ & - & - & -1.3 & 2.27 & 0.811440 & - \\
\hline & & 13 & $\sim 20$ & - & - & -1.2 & 2.1 & 0.810494 & - \\
\hline & & 14 & $\sim 20$ & 154 & - & - & - & - & - \\
\hline MS-2D-L1 & V & 1 & $\sim 10$ & 130.3 & - & 3.8 & Baixa & - & - \\
\hline & & 2 & $\sim 10$ & 128.3 & - & 1.6 & Baixa & - & - \\
\hline & & 3 & $\sim 10$ & - & - & - & - & - & - \\
\hline & & 4 & $\sim 10$ & 119.7 & - & - & - & - & - \\
\hline & & 5 & $\sim 10$ & - & - & 2.6 & Baixa & - & - \\
\hline & & 6 & $\sim 10$ & 124.6 & - & 5.5 & Baixa & - & - \\
\hline
\end{tabular}




\begin{tabular}{|c|c|c|c|c|c|c|c|c|c|}
\hline & & 7 & $\sim 10$ & - & - & - & - & - & - \\
\hline & & 8 & $\sim 10$ & 223.1 & -52 & -2.6 & 4.39 & 0.874555 & 16.2 \\
\hline & & 9 & $\sim 10$ & 97 & -51.2 & -0.6 & 1.08 & 0.967800 & 4.1 \\
\hline & & 10 & $\sim 10$ & - & - & -0.8 & 1.43 & - & - \\
\hline & & 11 & $\sim 10$ & 173.7 & - & 0 & 0 & 0.899398 & 9.9 \\
\hline & & 12 & $\sim 10$ & - & - & - & - & - & - \\
\hline & & 13 & $\sim 10$ & - & - & -1.3 & 2.27 & - & - \\
\hline & & 14 & $\sim 85$ & - & - & -3 & 5.02 & - & - \\
\hline & & 15 & $\sim 45$ & 412.7 & - & -2.1 & 3.59 & - & - \\
\hline \multirow[t]{10}{*}{ MS-2D-L1 } & $\mathrm{VI}$ & 1 & $\sim 15$ & 201.2 & -52.2 & -0.8 & 1.43 & 0.876270 & 13.5 \\
\hline & & 2 & $12-15$ & 146.3 & -53.5 & -2.3 & 3.91 & 0.948459 & 8.7 \\
\hline & & 3 & $\sim 25$ & 291.4 & -52.5 & -1 & 1.76 & 0.733235 & 27.9 \\
\hline & & 4 & $20-25$ & 274.6 & -51.6 & -1.7 & 2.93 & 0.781355 & 24 \\
\hline & & 5 & $\sim 15$ & 202.4 & -53 & -2.2 & 3.75 & 0.893911 & 13.8 \\
\hline & & 6 & $\sim 5$ & 83.2 & -50.9 & 0.3 & baixa & - & - \\
\hline & & 7 & $\sim 30$ & 312.9 & - & -1.6 & 2.77 & 0.703388 & 31.5 \\
\hline & & 8 & $\sim 15$ & 155.9 & - & 2.1 & Baixa & - & - \\
\hline & & M1 & mono & - & - & -0.9 & 1.6 & - & - \\
\hline & & M2 & mono & - & -52.3 & 0.3 & Baixa & - & - \\
\hline \multirow[t]{27}{*}{ MS-2D-L2 } & 1 & 1 & $\sim 10$ & 126.5 & -53.1 & -10.8 & 15.04 & 1.026368 & 11.4 \\
\hline & & 2 & $\sim 15$ & 84.2 & -53.2 & -15 & 19.06 & 1.092174 & 9.3 \\
\hline & & 3 & $\sim 15$ & 124.1 & -53.2 & -15.6 & 19.57 & 1.062185 & 12.2 \\
\hline & & 4 & $\sim 15$ & 121.6 & -48.9 & -16 & 19.91 & 1.067271 & 12.1 \\
\hline & & 5 & $\sim 15$ & 123.2 & -52.8 & -14.8 & 18.88 & 1.057136 & 12 \\
\hline & & 6 & $\sim 15$ & 93.1 & -52.8 & -14.6 & 18.71 & 1.080757 & 9.9 \\
\hline & & 7 & $5-10$ & 65.4 & -53.8 & -14.7 & 18.79 & 1.106534 & 7.8 \\
\hline & & 8 & $5-10$ & 61.9 & -52.1 & -12.5 & 16.76 & 1.087224 & 7.7 \\
\hline & & 9 & $5-10$ & 85.1 & -53.2 & -14.9 & 18.97 & 1.090446 & 9.3 \\
\hline & & 10 & $\sim 7$ & 87.6 & -52.9 & -14.9 & 18.97 & 1.088215 & 9.5 \\
\hline & & 11 & $\sim 15$ & 104.3 & -54.7 & -15.5 & 19.49 & 1.078567 & 10.8 \\
\hline & & 12 & $5-10$ & 119.9 & -53.9 & -15.1 & 19.14 & 1.062060 & 11.8 \\
\hline & & 13 & $\sim 15$ & 119.9 & -49.1 & -14.6 & 18.71 & 1.058368 & 11.8 \\
\hline & & 14 & $\sim 15$ & 103.4 & -49.5 & -14.6 & 18.71 & 1.072002 & 10.6 \\
\hline & & 15 & $\sim 15$ & 118.4 & -51.5 & -15.7 & 19.66 & 1.067813 & 11.8 \\
\hline & & 16 & $\sim 15$ & 118.4 & -50.9 & -15.2 & 19.23 & 1.064062 & 11.7 \\
\hline & & 17 & $\sim 15$ & 145.4 & -49.8 & -15.1 & 19.14 & 1.041190 & 13.6 \\
\hline & & 18 & $\sim 15$ & 121.1 & -51 & -15.5 & 19.49 & 1.064005 & 12 \\
\hline & & 19 & $\sim 15$ & 122.9 & -52.2 & -14.9 & 18.97 & 1.058107 & 12 \\
\hline & & 20 & $\sim 15$ & 127.1 & -48 & -15 & 19.06 & 1.055374 & 12.3 \\
\hline & & 21 & $\sim 15$ & 127.1 & -48.2 & -15 & 19.06 & 1.055374 & 12.3 \\
\hline & & 22 & $\sim 15$ & 127.3 & -50.1 & -15.4 & 19.4 & 1.058048 & 12.4 \\
\hline & & 23 & $\sim 15$ & 128.5 & -52 & -15.2 & 19.23 & 1.055635 & 12.4 \\
\hline & & 24 & $\sim 15$ & 132.5 & -47.6 & -13.7 & 17.89 & 1.042057 & 12.5 \\
\hline & & 25 & $\sim 15$ & 128.9 & -49.5 & -14.4 & 18.53 & 1.049699 & 12.3 \\
\hline & & 26 & $\sim 15$ & 126.9 & -47.2 & -13.5 & 17.71 & 1.044954 & 12.1 \\
\hline & & 27 & $\sim 15$ & 110.5 & -49.6 & -14.8 & 18.88 & 1.067640 & 11.2 \\
\hline
\end{tabular}




\begin{tabular}{|c|c|c|c|c|c|c|c|c|c|}
\hline & & 28 & $\sim 15$ & 115.7 & -49.9 & -15 & 19.06 & 1.064824 & 11.5 \\
\hline & & 29 & $\sim 15$ & 115.7 & -50.5 & -14.7 & 18.79 & 1.062553 & 11.5 \\
\hline & & 30 & $\sim 15$ & 118.2 & -53.3 & -15.6 & 19.57 & 1.067233 & 11.8 \\
\hline & & 31 & $\sim 15$ & 115.9 & -52.6 & -14.5 & 18.62 & 1.060881 & 11.5 \\
\hline & & 32 & $\sim 15$ & 132 & -51.4 & -15.6 & 19.57 & 1.055514 & 12.7 \\
\hline & & 33 & $\sim 15$ & 125.9 & -56.6 & -15.2 & 19.23 & 1.057789 & 12.3 \\
\hline & & 34 & $\sim 15$ & 131.9 & -49.9 & -15.4 & 19.4 & 1.054213 & 12.7 \\
\hline & & 35 & $\sim 15$ & 116.4 & -50.6 & -16.2 & 20.08 & 1.073368 & 11.7 \\
\hline & & 36 & $\sim 15$ & 119.8 & -53.2 & -15.2 & 19.23 & 1.062884 & 11.8 \\
\hline & & 37 & $\sim 15$ & 115.6 & -50.3 & -15 & 19.06 & 1.064907 & 11.5 \\
\hline & & 38 & $\sim 15$ & 129.1 & -51.2 & -15.7 & 19.66 & 1.058656 & 12.6 \\
\hline & & 39 & $\sim 15$ & 127.2 & -50.5 & -15.2 & 19.23 & 1.056711 & 12.4 \\
\hline & & 40 & $\sim 15$ & 152.7 & -51.4 & -15.8 & 19.74 & 1.039655 & 14.2 \\
\hline & & 41 & $\sim 15$ & 117.7 & -51.1 & -15.6 & 19.57 & 1.067664 & 11.7 \\
\hline & & 42 & $\sim 15$ & 114 & - & - & - & - & - \\
\hline MS-2D-L2 & II & 1 & $\sim 7$ & 105.1 & -53.8 & -15.6 & 19.57 & 1.078677 & 10.8 \\
\hline & & 2 & $\sim 5$ & 104.2 & -52.2 & -15.4 & 19.4 & 1.077836 & 10.8 \\
\hline & & 3 & $7-10$ & 120.3 & -53 & -15.8 & 19.74 & 1.066917 & 11.9 \\
\hline & & 4 & $\sim 5$ & 78.4 & -52.2 & -15.3 & 19.32 & 1.100521 & 8.8 \\
\hline & & 5 & $\sim 7$ & 100.3 & -51.7 & -16.6 & 20.41 & 1.091445 & 10.5 \\
\hline & & 6 & $\sim 7$ & 100.3 & -53.1 & -15.7 & 19.66 & 1.0838 & 10.5 \\
\hline & & 7 & $\sim 7$ & 111.1 & -52.6 & -15 & 19.06 & 1.068695 & 11.2 \\
\hline & & 8 & $\sim 10$ & 120 & -51.2 & -15.3 & 19.32 & 1.063458 & 11.9 \\
\hline & & 9 & $\sim 10$ & 129.9 & -51.7 & -15.2 & 19.23 & 1.054478 & 12.5 \\
\hline & & 10 & $\sim 10$ & 120.4 & -52.2 & -15 & 19.06 & 1.060904 & 11.9 \\
\hline & & 11 & $\sim 10$ & 112.3 & -51.8 & -15.3 & 19.32 & 1.070008 & 11.3 \\
\hline & & 12 & $\sim 10$ & 121.7 & -51.3 & -15.6 & 19.57 & 1.064231 & 12 \\
\hline & & 13 & $\sim 15$ & 127 & -51 & -15.9 & 19.83 & 1.061868 & 12.4 \\
\hline & & 14 & 5- 7 & 91.4 & -51.5 & -14.4 & 18.53 & 1.080478 & 9.8 \\
\hline & & 15 & $\sim 5$ & 91.4 & -52.4 & -14.7 & 18.79 & 1.083098 & 9.8 \\
\hline & & 16 & $\sim 7$ & 95.9 & -53 & -15.4 & 19.4 & 1.085206 & 10.1 \\
\hline & & 17 & $7-10$ & 112.9 & -53.7 & -15.3 & 19.32 & 1.069494 & 11.4 \\
\hline & & 18 & $7-10$ & 72.7 & -52.3 & -15.3 & 19.32 & 1.10572 & 8.4 \\
\hline & & 19 & $7-10$ & 109.4 & -53.4 & -16.1 & 19.99 & 1.07887 & 11.2 \\
\hline & & 20 & $7-10$ & 90.8 & -53 & - & - & - & - \\
\hline & & 21 & $7-10$ & 91.8 & -52.5 & - & - & - & - \\
\hline & & 22 & $7-10$ & 84.1 & -52.6 & -15 & 19.06 & 1.092264 & 9.3 \\
\hline & & A & $7-10$ & 109.5 & - & - & - & - & - \\
\hline & & B & $7-10$ & 99.8 & - & - & - & - & - \\
\hline & & $\mathrm{C}$ & $7-10$ & 110.4 & - & - & - & - & - \\
\hline & & $\mathrm{D}$ & $7-10$ & 95.2 & - & - & - & - & - \\
\hline & & $E$ & $7-10$ & 92.8 & - & - & - & - & - \\
\hline & & $\mathrm{F}$ & $7-10$ & 72.5 & - & - & - & - & - \\
\hline & & G & $7-10$ & 82.5 & - & - & - & - & - \\
\hline & & $\mathrm{H}$ & $7-10$ & 101.7 & - & - & - & - & - \\
\hline & & I & $7-10$ & 124.5 & - & - & - & - & - \\
\hline
\end{tabular}




\begin{tabular}{|c|c|c|c|c|c|c|c|c|c|}
\hline \multirow[t]{7}{*}{ MS-2D-L2 } & III & 1 & $\sim 7$ & 132.8 & -53.3 & -14.8 & 18.88 & 1.049345 & 12.7 \\
\hline & & 2 & $\sim 10$ & 118.7 & -53.5 & -15.2 & 19.23 & 1.063809 & 11.8 \\
\hline & & 3 & $\sim 10$ & 115.8 & -53.1 & -15.1 & 19.14 & 1.065498 & 11.6 \\
\hline & & 4 & $\sim 8$ & 87.7 & - & -15.2 & 19.23 & 1.090833 & 9.5 \\
\hline & & 5 & $\sim 8$ & 115.4 & -53 & -15.1 & 19.14 & 1.065835 & 11.5 \\
\hline & & 6 & $\sim 7$ & 85.2 & -53.8 & -14.7 & 18.79 & 1.088533 & 9.3 \\
\hline & & 7 & $\sim 7$ & 94.8 & - & -14.3 & 18.44 & 1.076736 & 10 \\
\hline \multirow[t]{20}{*}{ MS-2D-L2 } & IV & 1 & $\sim 12$ & 133.2 & -53.5 & -15.6 & 19.57 & 1.054509 & 12.8 \\
\hline & & 2 & $\sim 7$ & 109.4 & -53.9 & -15.2 & 19.23 & 1.071713 & 11.1 \\
\hline & & 3 & $\sim 10$ & 113.6 & -53.9 & -15.1 & 19.14 & 1.067355 & 11.4 \\
\hline & & 4 & $\sim 7$ & 122.5 & -53 & -15.4 & 19.4 & 1.062083 & 12.1 \\
\hline & & 5 & $7-10$ & 134.1 & - & - & - & - & - \\
\hline & & 6 & $7-10$ & 110.4 & -53.7 & -16.4 & 20.24 & 1.08036 & 11.3 \\
\hline & & 7 & $\sim 10$ & 119.9 & -53.2 & -15.1 & 19.14 & 1.06206 & 11.8 \\
\hline & & 8 & $\sim 7$ & 117.8 & -53.4 & -15.2 & 19.23 & 1.064568 & 11.7 \\
\hline & & 9 & $\sim 10$ & 119.4 & -54.5 & -15.2 & 19.23 & 1.063221 & 11.8 \\
\hline & & 10 & $\sim 10$ & 120.5 & - & - & - & - & - \\
\hline & & 11 & $7-10$ & 139.2 & - & - & - & - & - \\
\hline & & 12 & $\sim 10$ & 136.9 & - & - & - & - & - \\
\hline & & 13 & $7-10$ & 96 & - & - & - & - & - \\
\hline & & 14 & $\sim 7$ & 114 & - & - & - & - & - \\
\hline & & 15 & $\sim 11$ & 131.5 & - & - & - & - & - \\
\hline & & 16 & $\sim 10$ & 93.4 & - & - & - & - & - \\
\hline & & 17 & $\sim 10$ & 102.9 & - & - & - & - & - \\
\hline & & 18 & $\sim 10$ & 106.4 & - & - & - & - & - \\
\hline & & 19 & $\sim 7$ & 121.9 & - & - & - & - & - \\
\hline & & 20 & $20-25$ & 129.9 & - & - & - & - & - \\
\hline \multirow[t]{18}{*}{ MS-2D-L2 } & V & 1 & $\sim 10$ & 132 & -53.3 & -8.8 & 12.83 & 1.008817 & 11 \\
\hline & & 2 & $7-10$ & 139.8 & -53.7 & -8.8 & 12.83 & 1.003735 & 11.5 \\
\hline & & 3 & $\sim 10$ & 140.9 & -52.2 & -8.8 & 12.83 & 1.00301 & 11.5 \\
\hline & & 4 & $\sim 10$ & 151 & -53.8 & -9.4 & 13.52 & 1.000307 & 12.3 \\
\hline & & 5 & $\sim 10$ & 131.6 & -54.2 & - & - & - & - \\
\hline & & 6 & $\sim 10$ & 141.1 & - & -9 & 13.07 & 1.004252 & 11.6 \\
\hline & & 7 & $\sim 10$ & 131.3 & - & -9.3 & 13.41 & 1.012753 & 11.2 \\
\hline & & 9 & $\sim 10$ & 129.2 & - & -10.2 & 14.4 & 1.020379 & 11.3 \\
\hline & & 10 & $\sim 10$ & 127.6 & - & -8.8 & 12.83 & 1.011642 & 10.8 \\
\hline & & 11 & $7-10$ & 134.1 & - & -8.8 & 12.83 & 1.007458 & 11.1 \\
\hline & & 12 & $\sim 10$ & - & -52.4 & -8.7 & 12.72 & 0.978790 & \\
\hline & & 13 & $\sim 7$ & 138.4 & - & -3.7 & 6.09 & 0.966524 & 8.9 \\
\hline & & 14 & $\sim 10$ & 133.2 & -53 & -9 & 13.07 & 1.009433 & 11.2 \\
\hline & & 15 & $\sim 10$ & - & - & - & - & - & - \\
\hline & & 16 & $\sim 10$ & - & - & -8.6 & 12.6 & 0.978055 & - \\
\hline & & 17 & $\sim 10$ & - & -51.4 & -9.2 & 13.29 & 0.982409 & - \\
\hline & & $A$ & $\sim 10$ & 117.5 & - & - & - & - & - \\
\hline & & B & $\sim 10$ & 136.5 & - & - & - & - & - \\
\hline
\end{tabular}




\begin{tabular}{|c|c|c|c|c|c|c|c|c|c|}
\hline & & C & $\sim 10$ & 137.5 & - & - & - & - & - \\
\hline \multirow[t]{21}{*}{ MS-2D-L3 } & 1 & 1 & - & 100.3 & -55.2 & -11.4 & 15.66 & 1.048795 & 10 \\
\hline & & 2 & - & 100.4 & -56.2 & -11.5 & 15.76 & 1.049513 & 10 \\
\hline & & 3 & - & 157.4 & -55.7 & -11.3 & 15.56 & 1.008228 & 13.4 \\
\hline & & 4 & - & 96.3 & -54.6 & -11.4 & 15.66 & 1.051601 & 9.7 \\
\hline & & 5 & - & 113.6 & -54.2 & -11.8 & 16.07 & 1.042478 & 10.9 \\
\hline & & 6 & - & 112.3 & -55.1 & -12.4 & 16.66 & 1.047886 & 10.9 \\
\hline & & 7 & - & 116 & -54.2 & -12.5 & 16.76 & 1.045918 & 11.2 \\
\hline & & 8 & - & 85.6 & & -12.1 & 16.37 & 1.065163 & 9.19 \\
\hline & & 9 & - & 122.5 & -54.3 & -11.8 & 16.07 & 1.036178 & 11.4 \\
\hline & & 10 & - & 81.3 & -55.6 & -12.2 & 16.46 & 1.069264 & 8.9 \\
\hline & & 11 & - & 128.8 & -54.4 & -13.2 & 17.43 & 1.041421 & 12.1 \\
\hline & & 12 & - & 111.5 & -55.2 & -11.8 & 16.07 & 1.043968 & 10.8 \\
\hline & & 13 & - & 106.5 & -55.8 & -11.8 & 16.07 & 1.047525 & 10.4 \\
\hline & & 14 & - & 114.4 & -54.5 & -12.4 & 16.66 & 1.04635 & 11 \\
\hline & & 15 & - & 124.3 & -55.6 & -11.9 & 16.17 & 1.035611 & 11.5 \\
\hline & & 16 & - & 100.7 & -53.3 & -11.8 & 16.07 & 1.051668 & 10.1 \\
\hline & & $A$ & $7-10$ & 88 & - & - & - & - & - \\
\hline & & B & $7-10$ & 75.4 & - & - & - & - & - \\
\hline & & $\mathrm{C}$ & $\sim 10$ & 117.8 & - & - & - & - & - \\
\hline & & $\mathrm{D}$ & $\sim 10$ & 123.3 & - & - & - & - & - \\
\hline & & $E$ & $\sim 10$ & 158 & - & - & - & - & - \\
\hline \multirow[t]{10}{*}{ MS-2D-L3 } & II & M1 & mono & - & -57 & -10.8 & 15.04 & - & - \\
\hline & & $\mathrm{M} 2$ & mono & - & -56.6 & -10.5 & 14.72 & - & - \\
\hline & & M3 & mono & - & & -10.5 & 14.72 & - & - \\
\hline & & M4 & mono & - & -53.4 & -10.9 & 15.15 & - & - \\
\hline & & M5 & mono & - & & -11.3 & 15.56 & - & - \\
\hline & & M6 & mono & - & -56.3 & -9.7 & 13.85 & - & - \\
\hline & & M7 & mono & - & -55.3 & -8.8 & 12.83 & - & - \\
\hline & & M8 & mono & - & -53.7 & -9.5 & 13.63 & - & - \\
\hline & & M9 & mono & - & -56.9 & -9.9 & 14.07 & - & - \\
\hline & & M10 & mono & - & -55.5 & -9.9 & 14.07 & - & - \\
\hline \multirow[t]{12}{*}{ MS-2D-L3 } & III & $\mathrm{T} 1$ & $\sim 10$ & 139.2 & -55 & -0.1 & 0.23 & 0.933008 & 6.8 \\
\hline & & $\mathrm{T} 2$ & $\sim 10$ & 97.6 & -54.6 & -1.6 & 2.77 & 0.975303 & 5 \\
\hline & & T3 & $\sim 10$ & 124.7 & -55.6 & -1 & 1.76 & 0.952912 & 6.2 \\
\hline & & $\mathrm{T} 4$ & $\sim 20$ & 139.7 & -51.8 & -1.7 & 2.93 & 0.948031 & 7.8 \\
\hline & & T5 & $7-10$ & 130.3 & - & -0.2 & 0.4 & 0.941344 & 6.1 \\
\hline & & T6 & $\sim 10$ & 140 & - & -1.8 & 3.1 & 0.948726 & 7.9 \\
\hline & & $\mathrm{T7}$ & $\sim 10$ & 137.9 & - & -2.4 & 4.07 & 0.95574 & 8.1 \\
\hline & & $\mathrm{T} 8$ & $7-10$ & 119.5 & - & -1.2 & 2.1 & 0.958331 & 6 \\
\hline & & T9 & $7-10$ & 138.3 & - & - & - & - & - \\
\hline & & $\mathrm{T} 10$ & $7-10$ & 145.7 & - & - & - & - & - \\
\hline & & T11 & $\sim 10$ & 139.4 & - & - & - & - & - \\
\hline & & $\mathrm{T} 12$ & - & 110.4 & - & - & - & - & - \\
\hline MS-2D-L4 & 1 & 1 & $\sim 7$ & 168.7 & -53.6 & -12.8 & 17.05 & 1.009214 & 14.5 \\
\hline
\end{tabular}




\begin{tabular}{|c|c|c|c|c|c|c|c|c|c|}
\hline & & 2 & $\sim 7$ & 152 & -53.2 & -12.8 & 17.05 & 1.021574 & 13.5 \\
\hline & & 3 & mono & - & -54 & -9.9 & 14.07 & - & - \\
\hline & & 4 & $\sim 5$ & 141.4 & -53.5 & -12.7 & 16.95 & 1.028717 & 12.8 \\
\hline & & 5 & $\sim 20$ & 273.7 & -53.7 & -14.5 & 18.62 & 0.931911 & 22.3 \\
\hline & & 6 & mono & - & - & -10.4 & 14.62 & - & - \\
\hline & & 7 & mono & - & -55.5 & -10.2 & 14.4 & - & - \\
\hline & & 8 & mono & - & - & -10.4 & 14.62 & - & - \\
\hline & & 9 & mono & - & -52.8 & -10.2 & 14.4 & - & - \\
\hline & & 10 & $5-10$ & 91.4 & - & -12.3 & 16.56 & 1.062536 & 9.6 \\
\hline & & 11 & $\sim 15$ & 220.5 & -51.5 & -12 & 16.27 & 0.964294 & 17.7 \\
\hline & & 12 & - & 362.1 & -52.7 & - & - & - & - \\
\hline & & 13 & mono & - & - & -9.7 & 13.85 & - & - \\
\hline & & 14 & $7-10$ & 81.4 & - & -7.8 & 11.65 & 1.031949 & 7.9 \\
\hline & & 15 & $\sim 7$ & - & - & -5.1 & 8.12 & - & - \\
\hline & & $A$ & $\sim 5$ & 84.7 & - & - & - & - & - \\
\hline & & B & - & 197.2 & - & - & - & - & - \\
\hline MS-2D-L5 & 1 & 1 & $\sim 10$ & 131.9 & -53.7 & 1.3 & Baixa & - & - \\
\hline & & 2 & $\sim 10$ & - & - & 1.7 & Baixa & - & - \\
\hline & & 4 & $\sim 10$ & 137.2 & - & -2.3 & 3.91 & 0.955368 & 8 \\
\hline & & 5 & $\sim 10$ & - & - & 2 & Baixa & - & - \\
\hline & & 7 & $\sim 10$ & 114.8 & -54.3 & -14.7 & 18.79 & 1.063295 & 11.4 \\
\hline MS-2D-L5 & II & 8 & $\sim 10$ & 116.5 & - & -11.6 & 15.86 & 1.038963 & 11 \\
\hline & & 9 & $\sim 10$ & 105.8 & -50.3 & -12 & 16.27 & 1.049565 & 10.4 \\
\hline & & 10 & $\sim 10$ & 103.5 & - & -10.9 & 15.14 & 1.042695 & 10.1 \\
\hline & & 11 & $\sim 10$ & 103.3 & - & -12.1 & 16.37 & 1.052152 & 10.3 \\
\hline & & 12 & $\sim 10$ & 119.2 & -56 & -13.2 & 17.8 & 1.051584 & 11.6 \\
\hline & & 13 & $\sim 10$ & 109.4 & - & -13.1 & 17.33 & 1.055363 & 10.9 \\
\hline MS-2D-L5 & III & 14 & $\sim 10$ & 114.4 & -56.7 & -15.8 & 19.74 & 1.07206 & 11.5 \\
\hline & & 15 & $\sim 10$ & 93.8 & -56 & -16.9 & 20.65 & 1.100378 & 10 \\
\hline & & 16 & $\sim 10$ & 92.8 & -58.1 & -15.7 & 19.66 & 1.090644 & 9.9 \\
\hline & & 17 & $\sim 10$ & 99 & -58.5 & -14.2 & 18.35 & 1.07239 & 10.3 \\
\hline & & 18 & $\sim 10$ & 113.6 & - & -14.1 & 18.26 & 1.059715 & 11.3 \\
\hline & & 19 & $\sim 10$ & 100.2 & -58.2 & -14.2 & 18.35 & 1.071398 & 10.4 \\
\hline & & 20 & $\sim 10$ & 98.5 & -56.7 & -14.2 & 18.35 & 1.072805 & 10.3 \\
\hline & & 21 & $\sim 10$ & 98.5 & - & -15.4 & 10.4 & 1.082881 & 10.3 \\
\hline & & 22 & $\sim 10$ & 97.8 & -57.3 & -14 & 18.17 & 1.071719 & 10.2 \\
\hline & & 23 & $\sim 10$ & 105 & -56 & -13.8 & 17.98 & 1.064264 & 10.7 \\
\hline & & 24 & $\sim 10$ & 99.9 & -56.8 & -13.5 & 17.71 & 1.065909 & 10.3 \\
\hline & & 25 & $\sim 10$ & 104.9 & -55 & -14.7 & 18.79 & 1.071549 & 10.8 \\
\hline & & 26 & $\sim 10$ & 104.9 & -57 & -14.3 & 18.88 & 1.072356 & 10.8 \\
\hline & & 27 & $\sim 10$ & 101.4 & -57 & -14.3 & 18.88 & 1.071225 & 10.5 \\
\hline MS-2D-L5 & IV & 28 & $\sim 10$ & 102.5 & -58.7 & -13.8 & 17.98 & 1.066267 & 10.5 \\
\hline & & 29 & $\sim 10$ & 102 & -56.6 & -14 & 18.17 & 1.068288 & 10.5 \\
\hline & & 30 & $\sim 10$ & 104.1 & - & -14.3 & 18.44 & 1.068993 & 10.7 \\
\hline & & 31 & $\sim 10$ & 107.4 & - & -13.6 & 17.8 & 1.060785 & 10.8 \\
\hline & & 32 & $\sim 10$ & 82.2 & -57.6 & -13.9 & 18.08 & 1.083833 & 9.1 \\
\hline
\end{tabular}




\begin{tabular}{|c|c|c|c|c|c|c|c|c|c|}
\hline & & 33 & $\sim 10$ & 88.9 & - & -13.9 & 18.08 & 1.078216 & 9.6 \\
\hline & & 34 & $\sim 10$ & - & - & -14.7 & 18.79 & $1,017,111$ & - \\
\hline & & 35 & $\sim 10$ & - & - & -14.5 & 18.62 & $1,015,990$ & - \\
\hline & & 36 & $\sim 10$ & - & -55.5 & -14.9 & 18.97 & $1,018,222$ & - \\
\hline & & 37 & $\sim 10$ & - & -55.7 & -14.4 & 18.53 & $1,015,426$ & - \\
\hline & & 38 & $\sim 10$ & - & - & -14.3 & 18.44 & $1,014,860$ & - \\
\hline & & 39 & $\sim 10$ & - & - & -14.1 & 18.26 & $1,013,721$ & - \\
\hline & & P1 & $\sim 10$ & 114 & -56.5 & -14.9 & 18.97 & 1.065485 & 11.4 \\
\hline \multirow[t]{2}{*}{ MS-2D-L5 } & V & A & $\sim 20$ & 148.6 & - & 0.7 & Baixa & - & - \\
\hline & & B & $20-25$ & 168.7 & - & -2.2 & 3.75 & 0.928455 & 10.4 \\
\hline \multirow[t]{17}{*}{ MS-2D-L5 } & VI & 1 & $\sim 10$ & 152.7 & - & -1.6 & 2.77 & 0.936472 & 8.8 \\
\hline & & 2 & $\sim 20$ & 134.9 & -54.8 & 1.5 & Baixa & - & - \\
\hline & & 3 & $\sim 10$ & 121 & -57 & -12.6 & 16.85 & 1.042976 & 11.5 \\
\hline & & 4 & $\sim 10$ & 102.6 & - & -13.9 & 18.08 & 1.066993 & 10.5 \\
\hline & & 5 & $\sim 10$ & 95.5 & - & -11.8 & 16.07 & 1.055403 & 9.8 \\
\hline & & 6 & $\sim 10$ & 98.2 & -57.1 & -11.8 & 16.07 & 1.053461 & 9.9 \\
\hline & & 7 & $\sim 35$ & & - & -0.4 & 0.74 & - & - \\
\hline & & 8 & $\sim 10$ & 167.9 & - & 0.3 & Baixa & - & - \\
\hline & & 9 & $<10$ & 148 & - & 2.9 & Baixa & - & - \\
\hline & & 10 & $<10$ & 136.3 & - & 3.8 & Baixa & - & - \\
\hline & & 11 & $\sim 10$ & 118.9 & -57 & -10 & 14.18 & 1.02577 & 10.7 \\
\hline & & 12 & $<10$ & 108.2 & -57.5 & -10.1 & 14.29 & 1.033495 & 10.1 \\
\hline & & 13 & $\sim 10$ & 124.7 & - & 3.3 & Baixa & - & - \\
\hline & & 14 & $\sim 10$ & 132.5 & - & - & - & - & - \\
\hline & & 15 & $\sim 10$ & 145.6 & - & - & - & - & - \\
\hline & & 16 & $\sim 10$ & 120.8 & - & - & - & - & - \\
\hline & & 17 & $<10$ & 88.7 & - & - & - & - & - \\
\hline
\end{tabular}

$\mathrm{N}^{\circ} \mathrm{IF}=$ número da inclusão fluida; Vol_med=volume medido; THtot=Temperatura de Homogeneização total; TE=Temperatura Eutética; Tfg=Temperatura de fusão do gelo; Vol_cal=volume calculado. 